
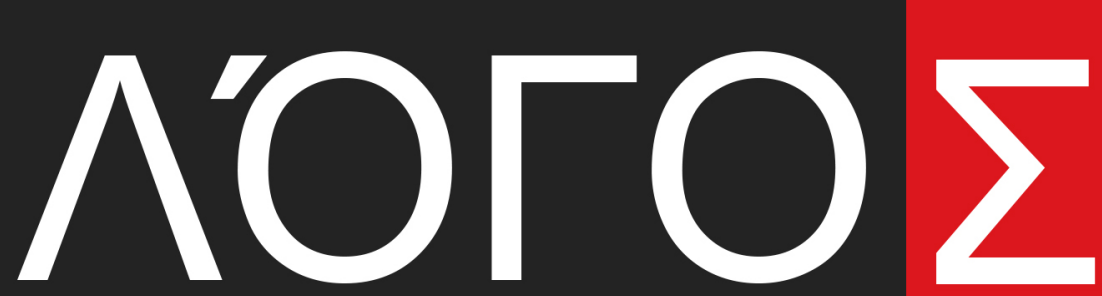

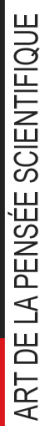

COLLECTION DE PAPIERS SCIENTIFIQUES

SUR LES MATÉRIAUX DE LACONFÉRENCE SCIENTIFIQUE ET PRATIQUE INTERNATIONALE

PROBLĖMES ET PERSPECTIVES D'NTRODUCTION DE LA RECHERCHE SCIENTIFIQUE INNOVANTE 29 NOVEMBRE 2019 • BRUXELLES, BELGIQUE —

\title{
VOLUME 3
}

DOI 10.36074/29.11.2019.v3

ISBN 978-617-7171-89-7

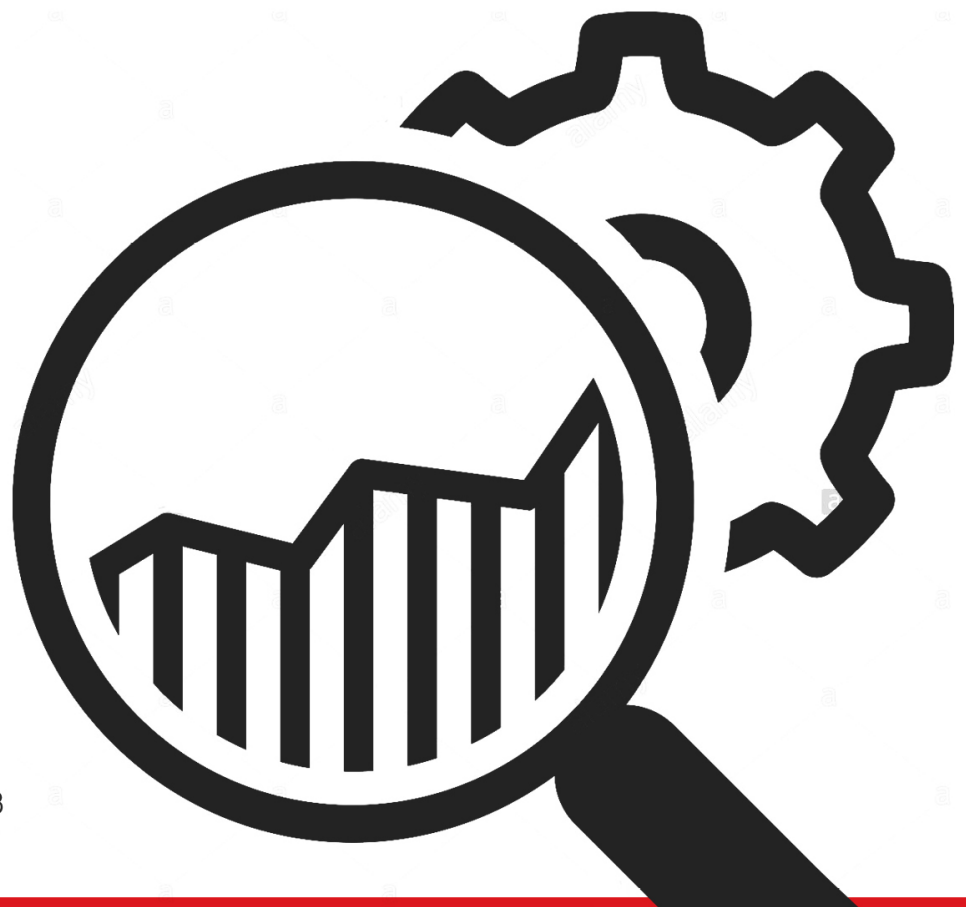



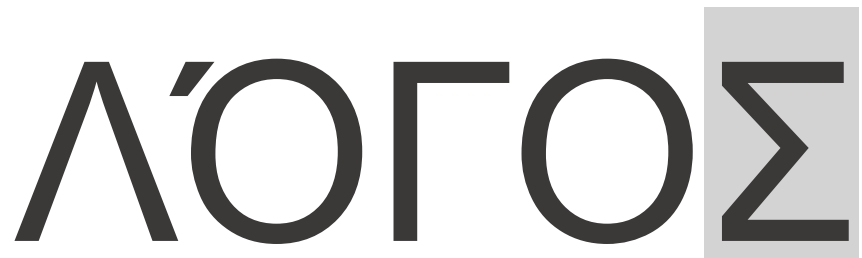

COLLECTION DE PAPIERS SCIENTIFIQUES

SUR LES MATÉRIAUX DE LA CONFÉRENCE SCIENTIFIQUE ET PRATIQUE INTERNATIONALE

«PROBLÈMES ET PERSPECTIVES D'INTRODUCTION DE LA RECHERCHE SCIENTIFIQUE INNOVANTE»

29 NOVEMBRE 2019

VOLUME 3

Bruxelles • Belgique 
P 93

Président du comité d'organisation: Holdenblat M.

Responsable de la mise en page: Kazmina $N$.

Responsable de la conception: Bondarenko I.

P 93 Problèmes et perspectives d'introduction de la recherche scientifique innovante: collection de papiers scientifiques

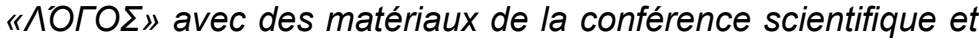
pratique internationale (Vol. 3), 29 novembre, 2019. Bruxelles, Belgique: Plateforme scientifique européenne.

ISBN 978-617-7171-89-7

DOI 10.36074/29.11.2019.v3

Les résumés et articles des participants à la conférence multidisciplinaire scientifique et pratique internationale «Problèmes et perspectives d'introduction de la recherche scientifique innovante», qui s'est tenue à Bruxelles le 29 novembre 2019, sont présentés.

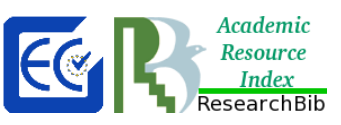

L'événement est inclus dans le catalogue des conférences scientifiques internationales, approuvé sur la plate-forme ResearchBib et certifié par Euro Science Certification Group norme scientifique SCC-2000.

Les documents de la conférence sont disponibles au public sous licence Creative Commons Attribution 4.0 International (CC BY 4.0).

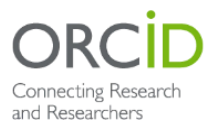

and Researchers

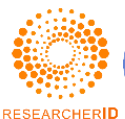

RESEARCHERID
La description bibliographique des documents de la conférence peut être téléchargée et indexée dans ORCID, Publons, Google Scholar, etc. 
29 novembre $2019 \bullet$ Bruxelles, Belgique $\bullet \mathbf{3}$

\section{CONTENU}

SECTION III.

SCIENCES TECHNIQUES ET TI

ОГЛЯД РІЗНОМАНІТНИХ ПІДХОДІВ ПРОГНОЗУВАННЯ ФІНАНСОВИХ ЧАСОВИХ РЯДІВ

Гурєєва К.М.

ОПТИМІЗАЦІЯ СКЛАДУ ГАЗОШЛАКОУТВОРЮЮЧОЇ ЧАСТИНИ ОСЕРДЯ САМОЗАХИСНОГО ПОРОШКОВОГО ДРОТУ

Науково-дослідна група:

Жаріков С.В., Гринь О.Г., Шахбазян В.Ф.

ОСОБЛИВОСТІ ЕФЕКТИВНОСТІ ЗАСТОСУВАННЯ ПАРОКОНВЕКЦІЙНИХ ШАФ РІЗНИХ ВИРОБНИКІВ У ЗАКЛАДАХ РЕСТОРАННОГО ГОСПОДАРСТВА

Гуцол О.М., Іваніщева О.А.

ПЕРЕСПЕКТИВИ НАПЛАВЛЕННЯ ПОРОШКОВИМИ ДРОТАМИ ДЕТАЛЕЙ ПРОМИСЛОВОГО ОБЛАДНАННЯ

Голуб Д.М., Бальоха Д.А.

ПРАКТИЧЕСКАЯ ЗНАЧИМОСТЬ ВИРТУАЛЬНОГО АЛФАВИТА УЗБЕКСКОГО ЯЗЫКА В ФОНЕТИКЕ

Норов А.М., Сайрихонова М.А.

ПРАКТИЧНІ РЕКОМЕНДАЦІЇ ПО ВДОСКОНАЛЕННЮ ОРГАНІЗАЦІЇ ТЕХНІЧНОГО ОБСЛУГОВУВАННЯ I ПОТОЧНОГО РЕМОНТУ АВТОМОБІЛІВ

Чмир В.М.

ПРИМЕНЕНИЕ ПОЛЕУРЕТАНОВЫХ СМОЛ В УСИЛЕНИИ ФУНДАМЕНТОВ ЗДАНИЙ И СООРУЖЕНИЙ

Костюкова М.А., Галясовский В.И.

ПРОБЛЕМИ ВПРОВАДЖЕННЯ СИСТЕМИ ТЕХНІЧНОГО ДІАГНОСТУВАННЯ В ДПСУ

Пухлий А.В.

ПРОБЛЕМЫ РАЗВИТИЯ ВЕТРОЭНЕРГЕТИКИ

Зарипова А.М., Владимиров С.Н.

ПРОМИСЛОВЕ ОТРИМАННЯ БАРВНИКІВ ДЛЯ ТРИАДИ ПЕРЕВОДНОГО ТЕРМОДРУКУВАННЯ НА ТКАНИНАХ 3 ПОЛІЕФІРНИХ СИНТЕТИЧНИХ ВОЛОКОН

Науково-дослідна група:

Вигоняйло О.І, Попов Є.В., Мороз О.В. 
4 - Problèmes et perspectives d'introduction de la recherche scientifique innovante $\bullet$ Volume 3

РАЗРАБОТКА ШАГАЮЩЕЙ СЕЯЛКИ ДЛЯ КРУГОВЫХ ЛЕСНЫХ ПИТОМНИКОВ

Бырдина С.С.

РЕАЛІЗАЦІЯ СИСТЕМИ ЗD-ВІЗУАЛІЗАЦІЇ МЕДИЧНИХ ЗОБРАЖЕНЬ ФOPMATY DICOM

Бондаренко Ю.Р.

РОБОТОТЕХНІКА В ЕРГОТЕРАПІЇ

Мироненко О.В.

РОЗРОБКА ЛІНІЙНОГО БЛОКУ ЖИВЛЕННЯ

Науково-дослідна група:

Байдацький I., Париський А., Фурман I.

ТЕХНИЧЕСКОЕ РЕГУЛИРОВАНИЕ В РАМКАХ ЕВРАЗИЙСКОГО ЭКОНОМИЧЕСКОГО СОЮЗА

Мусатаева Д.Т., Тайманова Г.К.

\section{SECTION IV.}

SCIENCES PHYSIQUES ET MATHÉMATIQUES

ПОХІДНА ДРУГОГО ПОРЯДКУ ЯК ІНСТРУМЕНТ РОЗВ ЯЗАННЯ

ТРАНСЦЕНДЕНТНИХ РІВНЯНЬ, ЩО МІСТЯТЬ ПАРАМЕТР

Новікова Н.В., Карнаух І.В.

\section{SECTION V. \\ SCIENCES CHIMIQUES}

ПЕДАГОГІЧНА ДІЯЛЬНІСТЬ ВЧИТЕЛЯ 3 ФОРМУВАННЯ КОМУНІКАТИВНИХ КОМПЕТЕНТНОСТЕЙ УЧНІВ ЗАСОБАМИ XIМІЧНОÏ ОСВІТИ: КОЛЕКТИВНИЙ СПОСІБ НАВЧАННЯ

Базілевська Л.П.

SECTION VI.

SCIENCES BIOLOGIQUES

БІОЛОГІЯ ТА ЕКОНОМІКА: ДИЛЕМА В'ЯЗНЯ ТА БІОЛОГІЧНІ ПРИЧИНИ ІРРАЦІОНАЛЬНОЇ ПОВЕДІНКИ

Тарасович В.C.

ВИДОВИЙ СКЛАД МАКРОМІЦЕТІВ РЕКРЕАЦІЙНИХ ЗОН СЕЛИДОВЕ Науково-дослідна група:

Приседський Ю.Г., Решетник К.С., Пляшечник В.В. 
ІНТЕНСИФІКАЦІЯ КАТАЛАЗНОЇ АКТИВНОСТІ ДЕЯКИХ ШТАМІВ БАЗИДІЄВИХ ГРИБІВ

Науково-дослідна група:

Приседський Ю.Г., Решетник К.С., Перестюк Ю.С.

ОСОБЛИВОСТІ САНІТАРНО-МІКРОБІОЛОГІЧНОГО СТАНУ ЗАКЛАДІВ ГРОМАДСЬКОГО ХАРЧУВАННЯ М. КИЇВ

Науково-дослідна група:

Машталер О.В., Решетник К.С., Сичова Г.С.

ПАТОГЕННА МІКРОФЛОРА ЇСТІВНИХ БАЗИДІЄВИХ ГРИБІВ В УМОВАХ ПРОМИСЛОВОГО КУЛЬТИВУВАННЯ

Науково-дослідна група:

Приседський Ю.Г. Решетник К.С., Беспалько А.С.

TВЕРДОФАЗНЕ КУЛЬТИВУВАННЯ PLEUROTUS OSTREATUS HA ВІДХОДАХ ЧАЮ

Мельник О.М.

ХАРАКТЕРИСТИКА ПОКАЗНИКІВ СЕРЦЕВО-СУДИННОЇ СИСТЕМИ ПІДЛІТКІВ В УМОВАХ СТРЕСУ

Раковець О.Ю.

\section{SECTION VII.}

SCIENCES MEDICALES

CLINICAL RESULTS OF DENTAL TREATMENT IN CHILDREN UNDER GENERAL ANESTHESIA

Research group:

Vovchenko L., Opanasenko O., Mozgova O., Savychuk O. 66

CONDITION OF PSYCHOLOGICAL ADAPTATION OF FAMILIES OF PATIENTS WITH DEMENTIA

Research group:

Kozhyna H., Zelenska K., Kaploukh O.

FEATURES OF CLINICAL MANIFESTATIONS OF THE ANXIETY DISORDERS IN INTERNALLY DISPLACED PERSONS

Research group

Zelenska K., Kraskovska T., Berezhnyi H., Zelenska H. .......................70

GENERAL ASPECTS OF TELEMEDICINE IN UKRAINE

Lesna A.

LEVEL OF ADAPTATION AND PERSONAL SELF-CONCEPTION IN PATIENTS WITH COSMETOLOGICAL PROBLEMS

Research group:

Kozhyna H., Markova M., Yudin M. 
6 - Problèmes et perspectives d'introduction de la recherche scientifique innovante $\bullet$ Volume 3

THE INTERRELATION BETWEEN BIOELECTRIC BRAIN ACTIVITY AND AFFECTIVE DISORDERS IN PATIENTS WITH EPILEPSY

Strelnikova I.

PSYCHOEDUCATION IN COMPLEX ASSISTANCE IN ANXIETYDEPRESSIVE DISORDERS IN SERVICEMEN WITH TRAUMATIC INJURIES OF EXTREMITY GREAT VESSELS

Koshchii V.

SANITARY AND EPIDEMIOLOGICAL ASPECTS OF THE PROBLEM OF SYNANTHROPIC ORGANISMS IN KHARKIV CITY

Research group:

Gerasimenko O., Bohachova O., Sarkis-Ivanova V., Nguyen Do To Uyen

THE DEGREE OF ADAPTATION DISORDERS IN CHILDREN FROM INTERNALLY DISPLACED FAMILIES

Research group:

Kozhyna H., Zelenska K., Samoilova O.

THE IMPORTANCE OF PSYCHOEDUCATION PROGRAMS IN ALCOHOL DEPENDENCE PATIENTS

Research group:

Kozhyna H., Zelenska K., Lytvynenko V.

THE STATE OF COLLECTIVE IMMUNITY TO THE VIRUS OF THE MEASLES OF THE POPULATION IN KIROVOGRAD REGION 2016-2018 Operchuk N.

THE STRUCTURE OF COMPUTER ADDICTION IN YOUNG PEOPLE

Research group:

Kozhyna H., Zelenska K., Starodubtseva Y.

АЛЛОПРЕГНАНОЛОН, ЯК ОДИН ІЗ ПРИЧИН РОЗВИТКУ АУТИЗМУ

Сечко А.O.

ВИЗНАЧЕННЯ ФУНКЦІОНАЛЬНОГО СТАНУ КЛІТИН БУКАЛЬНОГО ЕПІТЕЛІЮ ПРАЦІВНИКІВ ВО КАПРОЛАКТАМ» МЕТОДОМ ВНУТРІШНЬОКЛІТИННОГО ЕЛЕКТРОФОРЕЗУ

Сіренко О.В., Кучеренко Е.О.

ВПЛИВ НИЗЬКОÏ ТЕМПЕРАТУРИ НА ОРГАНІЗМ ДІТЕЙ

Research group:

Старусева В.В., Катамадзе Р.Н., Федоренко О.В.

ГІГІЄНА РУК У МЕДИЧНИХ ЗАКЛАДАХ ЯК НЕСПЕЦИФІЧНА ПРОФІЛАКТИКА ІНФЕКЦІЙ

Нечипоренко Є.А.

ГІГІЄНІЧНА ХАРАКТЕРИСТИКА УМОВ ПРАЦІ ЛИВАРНИХ ЦЕХІВ 
МАШИНОБУДІВЕЛЬНОГО ЗАВОДУ

Арзуманова І.В., Базян А.А.

ДОСЛІДЖЕННЯ ФАКТОРІВ, ЩО ВПЛИВАЮТЬ НА ПСИХІЧНЕ ЗДОРОВ'Я СТУДЕНТСТВА МЕДИЧНИХ ЗАКЛАДІВ ПІД ЧАС ЗДОБУТТЯ ВИЩОї ОСВІТИ

Науково-дослідницька група:

Кателевська Н.М., Дяченко І.О., Каднай О.С.

ЕМОЦІЙНЕ ВИГОРАННЯ У ЛІКАРІВ-ОНКОЛОГІВ

Братчук К.В., Оксененко Ю.Р.

ЕФЕКТИВНІСТЬ ВИКОРИСТАННЯ МОДИФІКОВАНИХ АДЕНО ТА ГЕРПЕС ВІРУСІВ ДЛЯ ТЕАРПІЇ ОНКОЛОГІЧНИХ ЗАХВОРЮВАНЬ Александрова К.В., Журавльова П.В.

НАПРЯМИ ДЕРЖАВНОГО РЕГУЛЮВАННЯ РИНКУ МЕДИЧНИХ ПОСЛУГ В УКРАЇНІ

Барзилович А.Д.

КЛІНІКО-АНАМНЕСТИЧНІ ФАКТОРИ РИЗИКУ УРАЖЕННЯ НИРОК У ДІТЕЙ, ХВОРИХ НА ІG-А ВАСКУЛІТ

Науково-дослідна група:

Грищенко Д.О., Гірка Д.Е., Шевченко Д.Ю., Яворович М.В.

МИКРОБИОМ И РАК: РАЗВИТИЕ И ЛЕЧЕНИЕ

Плотникова М.М., Линник В.Н.

ПРОБЛЕМА ЗАБРУДНЕННЯ НАВКОЛИШНЬОГО СЕРЕДОВИЩА ПЛАСТИКОМ

Науково-дослідна група:

Алієв Р. А., Камчатна В.А., Шенгелія Т.Є.

ПРОБЛЕМИ ВИКОРИСТАННЯ ЗD-ПРИНТИНГУ У ЛІКУВАННІ ХІРУРГІЧНИХ ХВОРИХ

Науково-дослідна група:

Кателевська Н.М., Дяченко І.О., Пелих І.М.

РАЗРАБОТКИ В ЛЕЧЕНИИ БОЛЕЗНИ ПАРКИНСОНА ПУТЕМ ИНГИБИРОВАНИЯ LRRK2

Кудрявых П.К.

РОЛЬ ОСНОВНИХ ФАКТОРІВ ВІРУЛЕНТНОСТІ HЕLICOВАСТЕR PYLORI У ВИНИКНЕННI РАКУ ШЛУНКА

Гордієнко П.О., Піонова О.М.

РОЛЬ СТРЕСУ У РОЗВИТКУ АКНЕ

Гулієва Е.М.

СЕПСИС

Санина Е.С., Лядова Т.И. 
8 - Problèmes et perspectives d'introduction de la recherche scientifique innovante $\bullet$ Volume 3

СИНДРОМ НЕДОСТАТНОСТІ АРОМАТАЗИ

Циганок О.С.

СРАВНИТЕЛЬНЫЙ АНАЛИЗ МЕТОДОВ СОВРЕМЕННОЙ РЕКОНСТРУКТИВНОЙ ХИРУРГИИ ТАЗОВОГО ДНА ПОСЛЕ ПРОВЕДЕНИЯ ЭКСТРАЛЕВАТОРНОЙ ПРОМЕЖНОСТНОЙ ЭКСТИРПАЦИИ ПРЯМОЙ КИШКИ ПРИ ЕЁ ОНКОЛОГИИ

Чеботенко О.Р., Йолдаш Д.Б.

СТАН НАВКОЛИШНЬОГО СЕРЕДОВИЩА ЯК ФАКТОР РИЗИКУ РОЗВИТКУ ДИТЯЧОГО АУТИЗМУ

Науково-дослідна група:

Кателевська Н.М., Нестеренко В.Г., Соколова І.В.

СТРУКТУРНО - ФУНКЦІОНАЛЬНІ ЗМІНИ ВНУТРІШНІХ ОРГАНІВ ЩУРІВ ПРИ ССL ${ }_{4}$ - IНТОКСИКАЦІЇ

Татаріна О.В.

СУЧАСНІ ПОГЛЯДИ ПРОФІЛАКТИКИ АЛЕРГІЙНИХ ЗАХВОРЮВАНЬ У ДIТЕЙ

Науково-дослідна група:

Старусева В.В., Гринчук К.О., Войтенко Т.С.

ФАКТОРИ, ЩО ВПЛИВАЮТЬ НА ЕФЕКТИВНІСТЬ НАВЧАННЯ СТУДЕНТІВ-МЕДИКІВ

Валентьєва А.В., Фадєєва А.В. 


\title{
SECTION III. SCIENCES TECHNIQUES ET TI
}

\section{ОГЛЯД РІЗНОМАНІТНИХ ПІДХОДІВ ПРОГНОЗУВАННЯ ФІНАНСОВИХ ЧАСОВИХ РЯДІВ}

\author{
Гурєєва Катерина Миколаївна
}

здобувач вищої освіти математичного факультету Запорізький Національний Університет

УКРAÏHA

Стандартними задачами при аналізі часових рядів $€$ прогнозування майбутніх значень ряду та класифікація рядів, наприклад, для виявлення аномальних даних. Прогнозуванню часових рядів присвячено досить багато публікацій, при цьому, класичні підходи, які розглядаються в цих роботах, також застосовуються і в аналізі фінансових часових рядів.

3 аналізу літературних джерел, можна зробити висновок, що задача прогнозування фінансових часових рядів, зокрема прогнозування цін криптовалют, є досить актуальною. Опубліковані на даний момент наукові статті можна умовно розділити на дві великі категорії.

До першої, відносять роботи, в яких виконується прогнозування на основі суто попередніх значень часового ряду. До методів, які застосовуються в цих публікаціях відносяться класичні статистичні підходи, наприклад, ARIMA, GARCH та інші варіанти цих алгоритмів. Також застосовуються прогностичні моделі на базі методів машинного навчання: методу опорних векторів, kнайближчих сусідів, дерев рішень, нейронних мережі різних типів. В багатьох статтях при попередній обробці даних використовується фільтрація за допомогою перетворення Фур'є або вейвлет перетворення. Можливі також різні комбінації всіх згаданих підходів [1].

До другої категорії можна віднести публікації в яких автори намагаються поєднати відомості про певні події (фінансові або політичні новини, кількість пошукових запитів користувачів) та історію попередніх значень часового ряду. Такі моделі $є$ більш складними за рахунок великої кількості параметрів. Стандартними підходами тут $€$ моделювання текстів за допомогою суто статистичних характеристик слів або застосування бібліотек, на кшталт, Word2Vec та GloVe, які використовують заздалегідь навчені нейронні мережі для перетворення тексту у числовий вектор. Після цього, числові вектори, що характеризують новини, поєднуються з історичними даними часових рядів цін валют, або використовуються для навчання класифікатора, що визначає як ціна впливає на курс.

На основі наведеного в роботі аналізу публікацій та методів, що в них застосовуються, можна зробити висновок, що найбільш перспективним напрямом досліджень є розробка гібридних систем, які поєднують в собі як прогнозування майбутніх значень часового ряду на основі історичних даних 
ряду даних, так і використання додаткових даних з новин, статистики пошукових запитів тощо. Одним з методів розробки таких гібридних систем може стати метод побудови ансамблю різних моделей машинного навчання, які б використовували для навчання різні дані.

\title{
Список використаних джерел:
}

1. Brockwell, P.J., Davis, R.A. (2016). Introduction to Time Series and Forecasting. New York : Springer.

2. De Gooijer, J.G. (2017). Elements of Nonlinear Time Series Analysis and Forecasting. New York: Springer.

DOI 10.36074/29.11.2019.v3.01

\section{ОПТИМІЗАЦІЯ СКЛАДУ ГАЗОШЛАКОУТВОРЮЮЧОЇ ЧАСТИНИ ОСЕРДЯ САМОЗАХИСНОГО ПОРОШКОВОГО ДРОТУ}

\begin{abstract}
НАУКОВО-ДОСЛІЖНА ГРУПА:
Жаріков Сергій Володимирович

канд. техн. наук, доцент кафедри обладнання і технологій зварювального виробництва Донбаська державна машинобудівна академія

Гринь Олександр Григорович канд. техн. наук, доцент, професор кафедри обладнання і технологій зварювального виробництва Донбаська державна машинобудівна академія

Шахбазян Володимир Фрідріхович здобувач вищої освіти факультету інтегрованих технологій і обладнання Донбаська державна машинобудівна академія УКPÄ̈HA
\end{abstract}

На промислових підприємствах України для виготовлювального і відновлювального наплавлення інструменту широко застосовуються самозахисні порошкові дроти (СПД). СПД, створюючи надійний захист розплавленого металу від взаємодії з повітрям, забезпечують гарні зварювально-технологічні властивості і високу продуктивність [1, 2]. Однак при наплавленні СПД спостерігається відставання плавлення осердя дроту від його оболонки, що негативно позначається на однорідності і властивостях наплавленого металу, призводить до забруднення металу шва неметалевими включеннями [3].

Одним із шляхів забезпечення рівномірності плавлення осердя і оболонки СПД є введення до складу їх шихти екзотермічних сумішей [4]. Однак введення екзотермічної суміші обмежує обсяг інших компонентів у складі шихти СПД, що може привести до погіршення газошлакового захисту наплавленого металу i зниження показників його механічних властивостей. Тому удосконалення складу газошлакоутворюючої частини осердя СПД, яка при меншій кількості 
забезпечує надійний захист металу від взаємодії з повітрям, є важливим завданням.

Для збереження захисних властивостей СПД з екзотермічної сумішшю, і забезпечення необхідного ступеня легування в якості газоутворюючих компонентів осердя використовується композиція карбонатів лужних і лужноземельних металів [2]. Використання композиції карбонатів забезпечує рівномірне виділення захисних газів в широкому діапазоні температур від $400 \square \mathrm{C}$ до $1500 \square \mathrm{C}$, що гарантує створення надійного захисту розплавленого металу від повітря. Варіювання вмістом композиції газошлакоутворюючих дозволяє впливати на кінетику газоутворення, рівномірність і повноту розкладання газоутворюючих компонентів шихти порошкового дроту.

На основі аналізу результатів розрахунку обсягу $\mathrm{CO}_{2}$, який виділяється при дисоціації карбонатів, і даних по температурі їх дисоціації в якості композиції карбонатів прийнята суміш $\mathrm{MgCO}_{3}, \mathrm{CaCO}_{3}, \mathrm{Li}_{2} \mathrm{CO}_{3}, \mathrm{Na}_{2} \mathrm{CO}_{3}$, як газоутворююча частина осердя СПД.

В роботі досліджувався вплив співвідношення компонентів композиції карбонатів на вміст кисню в наплавленому металі за допомогою математичного моделювання та статистичної обробки даних. Досліджувалося 15 варіантів складу осердя СПД з різним співвідношенням карбонатів. Карбонати вводилися в шихту осердя порошкових дротів при оптимальному співвідношенні газошлакоутворюючих компонентів - плавикового шпату і рутилового концентрату. Кількість газошлакоутворюючих компонентів в шихті осердя становило 9\% складу СПД. Частка композиції карбонатів у складі газошлакоутворюючої частини шихти становила 20\%. Вміст екзотермічної суміші в шихті осердя СПД складав 40 масових відсотків. Для визначення вмісту кисню проводилося багатошарове наплавлення з якого виготовлялися зразки діаметром 4 мм, масою 0,45 $\square 0,05$ г. Вміст кисню в наплавленні визначали на газоаналізаторі TC-136 форми "Leco".

Для аналізу результатів і побудови математичної моделі використовувався програмний пакет для статистичного аналізу Statistica 6. При створенні математичної моделі за основу прийнятий сімплексно-центроїдний план експерименту з 4 факторами, рандомізований порядок дослідів і спеціальна кубічна модель.

На основі аналізу рівнянь регресії і графічних зображень поверхонь відгуку в якості найбільш ефективної композиції карбонатів, що забезпечує низький вміст кисню в наплавленому металі, прийняте наступне співвідношення $\mathrm{CaCO}_{3}$ $=40 \%, \mathrm{Li}_{2} \mathrm{CO}_{3}=8 \ldots 13 \%, \mathrm{MgCO}_{3}=23 \ldots 35 \%, \mathrm{Na}_{2} \mathrm{CO}_{3}=17 \ldots 23 \%$. При такому вмісті карбонатів прогнозоване значення відгуку [O] $=0,0213 \%$. Дане співвідношення забезпечує надійний захист металу від кисню за рахунок рівномірного виділення захисних газів в широкому температурному інтервалі і покращує фрізичні та технологічні властивості шлаків.

Висновки. Найбільш ефективна композиція карбонатів $\mathrm{CaCO}_{3}=40 \%$, $\mathrm{Li}_{2} \mathrm{CO}_{3}=8 \ldots 13 \%, \mathrm{MgCO}_{3}=23 \ldots 35 \%, \mathrm{Na}_{2} \mathrm{CO}_{3}=17 \ldots 23 \%$, яка забезпечує низький вміст кисню в наплавленому металі за рахунок рівномірного виділення захисних газів в широкому діапазоні температур.

\section{Список використаних джерел:}

1. Розерт, Р. (2014). Применение порошковых проволок для сварки в промышленных условиях. Автоматическая сварка, (6-7), 60-64. 
2. Походня, И. К., Явдощин, И.Р., Пальцевич, А.П., Швачко, В.И. \& Котельчук, А.С. (2004). Металлургия дуговой сварки. Взаимодействие металла с газами. Київ: Наукова думка.

3. Походня, И. К., Суптель А. М. \& Шлепаков, В. Н. (1972). Сварка порошковой проволокой : монография. Київ: Наукова думка.

4. Чигарев, В. В., Зареченский, Д. А. \& Белик, А.Г. (2007). Особенности плавления порошковых лент с экзотермическими смесями в наполнителе. Автоматическая сварка, (2), 53-55.

\section{ОСОБЛИВОСТІ ЕФЕКТИВНОСТІ ЗАСТОСУВАННЯ ПАРОКОНВЕКЦІЙНИХ ШАФ РІЗНИХ ВИРОБНИКІВ У ЗАКЛАДАХ РЕСТОРАННОГО ГОСПОДАРСТВА}

\section{Гуцол Ольга Миколаївна}

Вінницький торговельно-економічний інститут КНТЕУ

Іваніщева О.А.

старший викладач

Вінницький торговельно-економічний інститут КНТЕУ

УКРАÏHA

Підбір корисного і якісного обладнання для ресторану - одна з основних задач при відкритті закладу. На професійних кухнях використовують велику кількість обладнання, головним призначенням якого $\epsilon$ скорочення часу технологічного процесу приготування страв. Переломним моментом в професійній кухні стало створення апарату, що поєднує в собі фуункції жарової шафри та пароварки - пароконвекційної печі. Перший пароконвектомат був презентований в 1976 році німецькою фірмою Rational.

В Україні пароконвекційні печі з'явились не так давно, але вже встигли зайняти чітку та впевнену позицію на кухнях ресторанів, кафе, та навіть їдалень. Попит на пароконвектомати росте з кожним днем, це вже стало модним трендом на професійних кухнях. Виконуючи близько $70 \%$ усіх можливих операцій теплової обробки продуктів, пароконвекційні печі можуть замінити величезну кількість теплового обладнання [1].

Існує два види пароконвекційних печей за способом утворення пари. До першого виду відносять бойлерні печі з парогенератором, до другого інжекторні, що утворюють пару періодичного впорскування вологи безпосередньо на трубчастий електронагрівач. Більшого поширення набула бойлерна піч, вона $є$ більш точною, ніж інжекторна і не потребує розрахунку, скільки потрібно води для виготовлення такої ж кількості пари [1].

За типом управління пароконвекційні печі бувають електромеханічними та електронними. Механічні печі оснащені поворотними ручками, за допомогою яких і відбувається регулювання параметрів. Такі печі дуже прості, але в них немає функції автоматичного регулювання вологості. Автоматичне регулювання здійснюється за допомогою трьох способів. В найдешевших моделях реалізований спосіб з фіксованим рівнем вологості. Другий варіант 3 
рівнем вологості 3 кроком $5 \% \in$ вже більш дорогим. Найновішим i найоптимальнішим $€$ третій варіант автоматичного контролю за допомогою датчиків і контролерів. Пароконвекційні печі класиффікують також за розміром (максимально можлива кількість гастроємностей). Виділяють малі (до шести), середні (до дванадцяти) та великі (до двадцяти) печі [2].

Якщо розглядати український ринок, то пароконвекційні печі з'явились нещодавно, але вони представлені великою кількістю брендів. До найбільш поширених належать печі від UNOX (Італія), LAINOX (Італія), PIRON (Італія), RETIGO (Чехія), RATIONAL (Німеччина), CONVOTHERM (Німеччина), BARTCHER (Німеччина), Інтеко-МАЙСTEP (Білорусь) [1].

Таблиця 1

Порівняння технічних характеристик пароконвектоматів різних моделей

\begin{tabular}{|c|c|c|}
\hline $\begin{array}{c}\text { № } \\
\text { П/П }\end{array}$ & Модель & Технічна характеристика \\
\hline 1 & ЭГР-5,0/380 & $\begin{array}{l}\text { Пароконвектомат (виробництво НПО «РОСС», м. Харків) } \\
\text { призначений для теплової обробки продуктів за } \\
\text { атмосферного тиску. Апарат складається з металевої } \\
\text { прямокутної шафи, яка, своєю чергою, складається з } \\
\text { герметичної робочої камери та зовнішнього каркасу. } \\
\text { Дверцята камери оснащені подвійним склом. Робоча } \\
\text { камера покрита теплоізоляцією, що сприяє зменшенню } \\
\text { теплових втрат. ТЕНи, розташовані всередині робочої } \\
\text { камери, забезпечують нагрівання повітря до заданої } \\
\text { температури, а вентилятор забезпечує циркуляцію } \\
\text { гарячого повітря. На стінках робочої камери розміщені } \\
\text { фіксатори, на які закріплюють знімні напрямні для лис- тів. } \\
\text { Зліва на стійці пароконвектомата розміщені бак для води, } \\
\text { пароутворювач та пульт керування. До пароутворювачу } \\
\text { подається вода з баку, де під дією нагрівальних елементів } \\
\text { випаровується і перетворюється на пару. }\end{array}$ \\
\hline 2 & $\begin{array}{c}\text { SELF } \\
\text { COOKING } \\
\text { CENTER } \\
\text { (SCC) }\end{array}$ & $\begin{array}{l}\text { Пароконвектомат (виробництво фірми «RATIONAL», } \\
\text { Німеччина) може виконувати близько 75\% операцій } \\
\text { обробки гарячого цеху, забезпечивши оптимальні умови } \\
\text { приготування страв (вологість, температуру обробки, час } \\
\text { приготування та інтенсивність обдування). Під час } \\
\text { використання апарату можна приготувати: м'ясо великими, } \\
\text { порційними і невеликими шматками, птицю, морепродукти } \\
\text { та рибу, випічку, гарніри. Система SelfCоoking Control } \\
\text { здатна сама розпізнати розмір продукту і визначити умови } \\
\text { приготування. Автоматично розраховуються температура, } \\
\text { тривалість і оптимальний режим обробки. } \\
\text { Пароконвектомат SCC здатний замінити собою основну } \\
\text { частину теплового устаткування гарячого цеху. }\end{array}$ \\
\hline 3 & $\begin{array}{c}\text { SURE CHEF } \\
\text { CSL }\end{array}$ & $\begin{array}{l}\text { Пароконвектомати серії SURE CHEF CSL (виробництво } \\
\text { фірми HENNY PENNY, CШA) виконані з високоякісної } \\
\text { нержавіючої сталі. Робоча камера зсередини має безшовну } \\
\text { структуру з округленими кутами, що сприяє максимально } \\
\text { вільній циркуляції повітря та простоту санітарної обробки. } \\
\text { Система кругових TEНів нагріває повітря в камері. } \\
\text { Вмонтований парогенератор призначений для отримання }\end{array}$ \\
\hline
\end{tabular}


14 - Problèmes et perspectives d'introduction de la recherche scientifique innovante $\bullet$ Volume 3

\begin{tabular}{|c|c|c|}
\hline $\begin{array}{c}\text { № } \\
\text { П/П }\end{array}$ & Модель & Технічна характеристика \\
\hline & & $\begin{array}{l}\text { пари без підвищення тиску в камері. Автоматика слідкує за } \\
\text { параметрами роботи парогенератора, яка вмикає } \\
\text { світодіодну індикацію запобіжного індикатора пониженого } \\
\text { тиску, відображаючи режим роботи клапана випуску пари, } \\
\text { індикатора наявності несправностей. Зливання води з } \\
\text { парогенератора та його промивання проходять } \\
\text { автоматично завдяки функції автоматичного промивання. } \\
\text { Всередині робочої камери завдяки вентилятору з } \\
\text { автоматичним реверсом гаряче повітря разом із парою } \\
\text { розподіляються рівномірно. Також елементи керування } \\
\text { можуть здійснювати фрункції імпульсного обертання } \\
\text { вентилятора з половинною швидкіст. Робоча камера } \\
\text { пароконвектоматів оснащена безфільтровою системою } \\
\text { видалення забруднень та захищеним внутрішнім } \\
\text { освітленням печі. Теплоізольовані дверцята з подвійним } \\
\text { склом, які навішуються окремо, закривають камеру. } \\
\text { Механізувати завантаження та вивантаження } \\
\text { пароконвектомата дає змогу використовувати стелажі на } \\
\text { роликах із пристроєм блокування руху. }\end{array}$ \\
\hline
\end{tabular}

Дані сформовано з [3]

Лідером ринку в Україні та за ії межами, слід назвати виробника конвекційних печей UNOX («Унокс»). Італійський бренд поставляє на ринок широку лінійку конвектоматів для випічки і кондитерського виробництва. Особливістю обладнання бренду $є$ подача в робочу камеру сухого повітря i видалення пари в кінці програми приготування. Таким чином, конвекційні печі UNOX дозволяють готувати хліб і іншу випічку з рівномірною внутрішньою структурою і незрівнянною хрусткою скоринкою, при цьому випічка зберігає свої властивості і не черствіє протягом декількох днів [3].

Сучасний рівень обміну професійною інформацією розширює уяву про новітні підходи до проектування, які повинні враховувати впровадження нових технологій, нових моделей торгово-технологічного устаткування, яке випускається. Установка такого обладнання, як пароконвектомати, оптимізує весь виробничий процес, знижуючи втрати сировини, енергоресурсів, часу на приготування страв та полегшує роботу працівників, поліпшує якість приготовлених страв, підвищує культуру обслуговування закладу ресторанного господарства.

\section{Список використаних джерел:}

1. Пароконвекційні печі - принцип роботи та види. Вилучено з https://torgoborud.com.ua/ua/Statti/parokonvekciyni-pechi-pryncyp-roboty-ta-vydy.

2. Особливості застосування пароконвективного устаткування в закладах ресторанного господарства. Вилучено з http://www.economyandsociety.in.ua/journal/13_ukr/81.pdf.

3. Павлюк, Р. Ю., Погарская, В. В. (2015). Крио- и механохимия в пищевых технологиях. Харьковский торгово-экономический институт Киевского национального торговоэкономического университета. 
DOI 10.36074/29.11.2019.v3.02

\title{
ПЕРЕСПЕКТИВИ НАПЛАВЛЕННЯ ПОРОШКОВИМИ ДРОТАМИ ДЕТАЛЕЙ ПРОМИСЛОВОГО ОБЛАДНАННЯ
}

\author{
Голуб Денис Михайлович \\ канд. техн. наук, доцент кафедри обладнання і технологій \\ зварювального виробництва \\ Донбаська державна машинобудівна академія
}

Бальоха Дмитро Андрійович здобувач вищої освіти фракультету інтегрованих технологій і обладнання Донбаська державна машинобудівна академія

УКPAÏHA

Згідно з прогнозів аналітичних компаній BCC Research i Transparency Market Research, вартісний обсяг ринку зварювальних матеріалів до 2020 p досягне 24-25 млрд дол. США, серед яких доля порошкового дроту складає близько $20 \%$, а щорічне зростання у 2014-2020 рр. очікується на рівні 4,5$5,3 \%$. Основними галузями, в яких широко використовуються технології зварювання порошковими зварювальними матеріалами $є$ суднобудування і будівництво морських споруд, мостобудування, виготовлення судин i контейнерів, промислове будівництво, енергетика, будівництво трубопроводів [1-4].

Таким чином, незважаючи на відносно високу вартість у порівнянні 3 суцільними, порошкові дроти затребувані на світовому ринку зварювальних матеріалів і зважаючи на широке застосування технологій зварювання і наплавлення порошковими дротами в економічно розвинених країнах їх споживання в промисловості і будівництві щорічно зростає та їх частка у загальному ринку складає (\%): Корея - 40,0; Японія - 35,9; Північна Америка 22,1; ЄС - 19,1; Тайвань - 18,8. [2, 3, 4].

Не менш широко застосовується порошковий дріт для різних наплавних робіт при ремонті, технічному обслуговуванні і поверхневому зміцненні і термічному напиленні. Наплавлення деталей промислового обладнання порошковими дротами $€$ ефективним методом ресурсозбереження та відновлення геометрії деталей і підвищення експлуатаційної стійкості шляхом нанесення спеціальних сплавів, що володіють високою зносостійкістю і забезпечують багаторазове відновлення робочої геометрії деталей.

В обсязі ринку зварювальних матеріалів дляремонту і технічного обслуговування порошковий дріт займає $24 \%[2,5]$.

Негативною рисою порошкового дроту $є$ істотний вплив якості підготовки шихти і технології виготовлення дроту на його зварювально-технологічні властивості i, як наслідок, на задоволення експлуатаційної надійності i здатності протистояти різним видам зношування наплавленого металу.

Висновки. У зв'язку з вищевказаним, проведення комплексних досліджень, спрямованих на вдосконалення технологічних прийомів, технічних i організаційних заходів щодо вдосконалення складів порошкових дротів і способів їх виготовлення, що дозволяють скорочувати капітальні вкладення по 
заміні зношеного промислового обладнання, являє собою актуальну задачу, що має важливе наукове і практичне значення для промислового комплексу України та світу.

\section{Список використаних джерел:}

1. Походня, И. К., Суптель А. М. \& Шлепаков, В. Н. (1972). Сварка порошковой проволокой: монограффия. Київ: Наукова думка.

2. Мазур, А. А., Маковецкая, О.К., Пустовойт, С.В. \& Бровченко, Н. С. (2015) Порошковые проволоки на мировом и региональных рынках сварочных материалов (Обзор). Автоматическая сварка, (5-6), 68-74.

3. Welding products market is set to reach USD 23.78 billion by 2010 .Retrieved from http://www.rtansparencymarketresearch.com.

4. Victor Technology Group, Inc. Annual report 2013. Retrieved from http://www.victortechnologies.com.

5. Chauhan, A. Welding requirements for repairs and maintenance increased adoption of preventive maintenance leads the market for welding. Retrieved from http://www.frost. com.

\section{ПРАКТИЧЕСКАЯ ЗНАЧИМОСТЬ ВИРТУАЛЬНОГО АЛФАВИТА УЗБЕКСКОГО ЯЗЫКА В ФОНЕТИКЕ}

Норов Абдисаит Мурадович

старший преподаватель кафедры «Методика преподавания информатики»

Каршинский государственный университет

Сайрихонова Мохидил Азизхон кизи студентка 4 курса Физико-математического фракультета Каршинский государственный университет

РЕСПУБЛІКА УЗБЕКИСТАН

В настоящее время проводится много исследований по применению автоматизированных информационных систем в узбекской лингвистике. Особого внимания заслуживают работы [1] проведенные над узбекским, русским и английскими языками по моделированию частей речи $и$ предложений связанные с синтаксисом, семантикой и базами данных для формирования слов.

К сожалению, пока не существуют разработки фонетических или фонологических анализаторов для узбекского языка. Данная работа, может быть, восполнить какую-то часть этого пробела.

Следует отметить, что сейчас, во времена технического прогресса трудно вести научные размышления о фонограммах, подобных национальному алфавиту, для того чтобы гармонично войти в международный научный круг, вести интеллектуальную деятельность подобно информационному сообществу. Для внедрения узбекского языка в автоматизированную информационную систему, являющейся центральной ячейкой современного прогресса, требуется ещё более расширить его сферу исследования. 
Существуют разнообразные методы, направленные решению данной проблемы, один из которых метод виртуального расширения алфавита.

Программистам хорошо известно о необходимости дополнительного алфавита, исполняющего роль помощника при создании лингвистического программного обеспечения подобно современным устройствам. Дополнительный алфавит может состоять из букв, символов и различных фонетических знаков, имеющихся в другом языке. Значить, в случае, если например, у исследуемого языка будет наблюдаться нехватка имеющихся орфографических возможностей, основной алфавит будет дополнен за счет дополнительного алфравита. Этот алфавит является алфравитом научного круга и служит основой для устранения некоторых узких мест данного языка и разработки научных моделей в области лексикологии, фонетики, морфологии и синтаксиса (табл. 1).

Таблица 1

Модификация узбекского фонетического алфавита на основе МФА

\begin{tabular}{|c|c|c|c|}
\hline $\begin{array}{c}\text { Узбекский } \\
\text { алфавит }\end{array}$ & $\begin{array}{c}\text { Узбекский } \\
\text { фонетический } \\
\text { алфавит } \\
\text { (традиционный) }\end{array}$ & $\begin{array}{c}\text { Узбекский } \\
\text { фонетический } \\
\text { алфавит по МФА }\end{array}$ & Пример \\
\hline A & $\partial\left(601_{10}\right)$ & $a\left(97_{10}\right)$ & ana [ana] \\
\hline B & $\mathrm{b}$ & $\mathrm{B}$ & bola [bola] \\
\hline $\mathrm{D}$ & $d$ & $\mathrm{D}$ & devon [d $[\varepsilon v o n]$ \\
\hline $\mathrm{E}$ & e (10110) & $\varepsilon\left(603_{10}\right)$ & elchi $[\varepsilon|t| f i]$ \\
\hline $\mathrm{F}$ & $\varphi\left(966_{10}\right)$ & $f\left(102_{10}\right)$ & fazo [fazo] \\
\hline $\mathrm{G}$ & $\mathrm{g}$ & $\mathrm{G}$ & gul [gul] \\
\hline $\mathrm{H}$ & $\mathrm{h}$ & $\mathrm{H}$ & haj [hactz] \\
\hline $\mathrm{I}$ & $\mathrm{i}$ & $\mathrm{I}$ & inson [inson] \\
\hline $\mathrm{j}(\mathrm{dj})$ & Ç $\left(231_{10}\right)$ & $\mathrm{d} z \mathrm{(677_{10 } )}$ & jiyda [dzijda] \\
\hline $\mathrm{J}$ & $\bar{z}\left(382_{10}\right)$ & $z(656)$ & jurnal [zurnal] \\
\hline $\mathrm{K}$ & $\mathrm{k}$ & $\mathrm{K}$ & kelin [kelin] \\
\hline $\mathrm{L}$ & $\mathrm{I}$ & $\mathrm{L}$ & lekin [lEkin] \\
\hline $\mathrm{M}$ & $\mathrm{m}$ & $\bar{M}$ & men [men] \\
\hline $\mathrm{N}$ & $\mathrm{n}$ & $\mathrm{N}$ & nok [nJk] \\
\hline $\mathrm{O}$ & J (596 10$)$ & o (596 10$)$ & oshiq [ग]iq] \\
\hline $\mathrm{P}$ & $p$ & $\mathrm{P}$ & pashsha [pa $\left.\iint a\right]$ \\
\hline $\mathrm{Q}$ & $q$ & $q$ & qo'l [qel] \\
\hline $\mathrm{R}$ & $r$ & $r$ & orom [orom] \\
\hline $\mathrm{S}$ & $\mathrm{s}$ & $\mathrm{s}$ & sevgi [s\&vgi] \\
\hline$T$ & $t$ & $t$ & tuz [toz] \\
\hline ts (ц) & 4 & ts $\left(678_{10}\right)$ & dotsent [dotsent \\
\hline U & $Y\left(947_{10}\right)$ & $v\left(650_{10}\right)$ & uchun [utforn] \\
\hline $\mathrm{V}$ & $\mathrm{v}$ & v & vojib [vockib] \\
\hline $\mathrm{x}$ & $x$ & $\mathrm{x}$ & xola [xola] \\
\hline$y$ & $y$ & $j$ & yosh [jo]] \\
\hline$z$ & $z$ & $z$ & zeb [zeb] \\
\hline $0^{\circ}$ & $\theta\left(629_{10}\right)$ & $\theta\left(629_{10}\right)$ & ón [өn] \\
\hline$g^{6}$ & $\psi\left(968_{10}\right)$ & L $\left(641_{10}\right)$ & g'Oz [вวz] \\
\hline sh & ş $\left(351_{10}\right)$ & $\int\left(643_{10}\right)$ & shosh [Jj] \\
\hline ch & $\mathrm{c}$ & $\mathrm{tf}\left(679_{10}\right)$ & choy [t’j]] \\
\hline $\mathrm{ng}$ & $\eta\left(951_{10}\right)$ & $\eta\left(331_{10}\right)$ & go'ng [gen] \\
\hline
\end{tabular}


18 - Problèmes et perspectives d'introduction de la recherche scientifique innovante $\bullet$ Volume 3

Теперь, более подробно остановимся на необходимых аспектах виртуального расширения алфавита и его практическом значении. Основная часть потребности по виртуальному расширению алфавита приходится именно на фонетику узбекского языка. Известно, что понятия буква, цифра, знаки препинания являются для компьютера чужими, и все они воспринимаются одним словом - символ. Для каждого из этих символов выделен отдельный специальный код, выражающийся при помощи 10-чных или 16-чных цифр. Исходя из этого, все фонемы, для точного «понятного» произношения компьютеру, должны обозначаться неповторимыми символами на основе транскрипционных принципов.

Для полного восприятия, высказанного, приведем в качестве примера несколько проблемных примеров:

1) для обозначения слов «журнал» и «жийда» не целесообразно использование одной буквы «ж», необходимо применить имеющиеся в компьютере символы «ж» и «ж» (если на латинском «ј» и «іิ»).

2) в случае использования сочетания двух букв (графемы), обозначающих один звук при создании программного обеспечения, способного разделить слоги, возникнут трудности с правильным произношением и прочтением текста.

3) в словах, заимствованных из русского языка гласная «о», исходя из места, занимаемого в составе слова, произносится по разному: иногда «и» (директор - директир), иногда «а» (океан - акеан), а иногда «ў» (электр токи - электр тугки). Значит, создание подходящих модификаций шрифттов (или принятие имеющихся транскрипционных знаков) для различного произношения одной буквы будет полезным для предотвращения речевой неточности.

По выводы узбекских ученых-языковедов, в узбекском языке 48 речевых звуков (нелабиализованных гласных - 10, лабиализованных гласных - 6, сонантов - 6 и консонантов - 26) каждую из них обозначает в транскрипции и дает характеристику [2].

В общем, алфавит, который мы имеем ввиду выполняет функцию «продукта» для лингво-математического моделирования, объединяющего в себе необходимые звуки препинания, цифры, лигатуру и диакритические знаки и через него возможно создания новой формальной грамматики, потому что оно рассматривается как необходимое событие. Истинный смысл системы общения «человек-машина» в конце концов, окажется в сфере автоматической системы перевода. На основе автоматического перевода лежит вопросы разработки и генерации естественного языка. В связи с этим, степень качественности автоматического перевода на наш взгляд отмечается безошибочной, своей местной расстановкой синтаксической структуры фразы.

\section{Список используемых источников:}

1. Хакимов, М.М. (2019). Технология многоязыкового моделируемого компьютерного переводчика. Academic Publishing, 108-115.

2. Миртожиев, М. (2013). Ўзбек тили фонетикаси. Тошкент: Фан. 


\title{
ПРАКТИЧНІ РЕКОМЕНДАЦІЇ ПО ВДОСКОНАЛЕННЮ ОРГАНІЗАЦІЇ ТЕХНІЧНОГО ОБСЛУГОВУВАННЯ I ПОТОЧНОГО РЕМОНТУ АВТОМОБІЛІВ
}

\begin{abstract}
Чмир Віктор Миколайович
кандидат технічних наук, доцент, доцент кафедри

транспортних засобів та спеціальної техніки

Національна академія Державної прикордонної служби України імені Б. Хмельницького

УКРАÏHA
\end{abstract}

3 метою забезпечення високої технічної готовності рухомого складу автотранспортних підприємств, покращення технічного стану парку автомобілів та зниження витрат на їх поточний ремонт потребує вдосконалення організації виробництва з технічного обслуговування (ТО) i поточного ремонту (ПР). Об'єм і характер робіт по ТО і особливо по ПР значно змінюються в залежності від пори року, кліматичних і дорожніх умов, конструкції і віку автомобілів і т.п. [2]. Щоб своєчасно і якісно виконати часто змінюваний об'єм робіт, організація виробництва повинна бути чіткою і гнучкою.

Крім цього, в даний час переважна частина витрат на ТО і ПР складає заробітна плата і вартість запасних частин. На зниження цих витрат також найбільш ефективно можливо впливати організаційними заходами. Шляхом організації своєчасного і високоякісного виконання робіт по ТО і ПР автомобілів можливо різко зменшити періодичність ПР і за рахунок цього понизити затрати праці і витрату запасних частин.

Але до цієї пори переважна більшість інженерно-технічних працівників автомобільного транспорту все ще недооцінюють значення організації виробництва, а наукові і керівні органи рішають лише окремі питання організації виробництва без їх необхідного взаємозв'язку з іншими питаннями виробництва.

В цих умовах інженерно-технічні працівники автотранспортних підприємств змінюють організацію виробництва по своєму досвіду без аналізу результатів роботи виробництва. Це призвело до великої кількості різних форм організації виробництва.

Тому на основі аналізу організаційних фрорм побудови технологічного процесу ТО і ПР автомобілів [2], пропонується агрегатно-дільнична форма організації виробництва, застосування якої усуває недоліки діючої організації і покращує значно покращити технічний стан автомобілів і знизити витрати на ТО i ПР.

Таким чином, коли виробництво організовано по запропонованій формі, в автотранспортних підприємствах створюються необхідні умови для більш ефективного використання виробничого персоналу, матеріальної бази, запасних частин і т.п. В той же час при застосуванні даної форми організації виробництва спостерігаються недоліки і помилки, багато з яких можуть бути усунуті і навіть попереджені шляхом своєчасного вивчення і освітлення досвіду роботи автотранспортних підприємств. 


\section{Список використаних джерел:}

1. Chmyr, V. M. (2005). Obgruntuvannia orhanizatsiinykh rishen shchodo udoskonalennia systemy tekhnichnoho obsluhovuvannia i remontu avtomobilnoi tekhniky [Substantiation of organizational decisions on improvement of the system of maintenance and repair of automobile equipment]. Khmelnitsky: KhNU, (6), 95 - 98. [in Ukrainian].

2. Ludchenko, O. A. (2007). Tekhnichna ekspluatatsiia i obslurovuvannia avtomobiliv: Texnolohiia. Kyiv: Vyshcha shkola. [in Ukrainian].

\section{ПРИМЕНЕНИЕ ПОЛЕУРЕТАНОВЫХ СМОЛ В УСИЛЕНИИ ФУНДАМЕНТОВ ЗДАНИЙ И СООРУЖЕНИЙ}

Костюкова Мария Александровна

получатель высшего образования строительного факультета Приднепровская государственная академия строительства и архитектуры

Галясовский Владислав Иванович

получатель высшего образования строительного факультета Приднепровская государственная академия строительства и архитектуры УКРАИНА

В условиях плотной городской застройки как никогда актуальным стал вопрос усиления фундаментов зданий, примыкающих к возводимому объекту . Не смотря на достаточно большой срок службы фундаментов и их высокую износостойкость все негативные фракторы окружающей среды приводят к увеличению напряженно-деформируемого состояния грунтов. При этом всегда необходима расчетная оценка прочностных и деформационных свойств оснований фундаментов. При недостаточной несущей способности по какой-либо из двух групп предельных состояний необходимо проведение усиления грунтового основания.

Помимо уже известных методов усиления грунтов существуют сравнительно новые, современные, требующие инновационных подходов и детального изучения. Одним из них является метод «глубинного инъецирования основании полеуретановыми смолами» ,позволяющий укрепить фрундаменты старинных зданий, памятников архитектуры, исправить ошибки нового строительства, устранить угрозу обрушения конструкций в случае стихийного бедствия после оседания фундамента или тротуара, вызывающего трещины в здании.

Инъецирование позволяет осуществлять глубокие и поверхностные экспансивные закачки смолы, достигая значительных глубин на нескольких наложенных уровнях, с целью целенаправленного, эффрективного и равномерного уплотнения объемов почвы, подверженных структурным нагрузкам, стабилизации здания на грунтовом основании, его выравнивании.

Сначала смола проникает в почву путем пропитки или разрушения. На втором этапе, благодаря давлению расширения, смола уплотняется и стабилизирует почву. Растяжимые полиуретановые смолы-полимеры или полиуретаны образуют большое семейство полимеров, которые характеризуются различными физическими свойствами, в том числе их 
способностью к расширению (набуханию). Сила расширения смолы достаточна для подъема здания, расположенного на закачиваемом грунте. Именно этот миллиметровый подъём непрерывно контролируется лазерными уровнями, что обеспечивает сопротивление грунту и оптимальный подъем.

Непосредственно перед инъекциями инженер или геолог, отвечающий за проведение работ, проводит предварительную диагностику с помощью геофизических измерений и геотехнических испытаний, которые позволяют определить механические и электрические свойства грунта. Эти исследование позволяют гарантировать, что фраза впрыска полимерной смолы проходит в наилучших условиях.

На основе геоэлектрической модели грунта под конструкцией, выполняется серия небольших перфораций с максимальным диаметром 2530 мм изготавливается целевым способом для последующего впрыскивания смолы. Металлические трубки, используемые для инъекций, вводятся в перфорации в соответствии и заполняются инъецируемым раствором.

Полиуретановые смолы можно закачивать в почву на различных глубинах за счет небольших диаметров скважин, что позволяет избежать ослабления фрундаментных конструкций.

ВЫВОДЫ: На данный момент метод инъецирования все больше набирает популярность в современном строительстве и реконструкции благодаря широкому спектру действий и области применения( от восстановления старых построек и реставрации архитектурных сооружений до исправления ошибок нововозведенных зданий).

Инъецирование позволяет укрепить не только основание, но и стены, кровлю, перекрытия, все сооружение в целом, перераспределить нагрузку на основание, подходит для всех видов грунтов и фундаментов. Единственным недостатком данного метода является его высокая стоимость, который без сомнений компенсируется мощным результирующим эфрфектом.

\title{
ПРОБЛЕМИ ВПРОВАДЖЕННЯ СИСТЕМИ ТЕХНІЧНОГО ДІАГНОСТУВАННЯ В ДПСУ
}

\begin{abstract}
Пухлий Аркадій Васильович
курсант інженерно-технічного факультету Національна академія Державної прикордонної служби України ім. Б. Хмельницького

Науковий керівник: Корєхов А.О.

старший викладач кафредри транспортних засобів та спеціальної техніки Національна академія Державної прикордонної служби України ім. Б. Хмельницького
\end{abstract} УКРАÏHA

Сучасна структура Державної прикордонної служби України (ДПСУ) тісно пов'язана з використанням сучасних зразків техніки. Не винятком $\epsilon$ i транспортні засоби, які використовуються для виконання поставлених задач. Останні два роки досить активно почалось впровадження сучасних транспортних засобів як вітчизняного так і іноземного виробництва. Але сучасні зразки техніки мають все більш складні конструктивні особливості, які 
не дають можливість якісно обслуговувати техніку без спеціального діагностичного обладнання.

Сама структура діагностування в ДПСУ, як така - відсутня, а є тільки окремі дії штатних підрозділів, які намагаються утримувати транспортні засоби в працездатному стані. Ці заходи притаманні зразкам техніки які вже знаходяться в штаті тривалий час.

Відповідно, активне впровадження новітньої техніки автомобілів різної марки як вітчизняного так і іноземного виробництва, ставить перед структурою досить складні завдання: удосконалення матеріальної бази ДПСУ, підготовку персоналу інженерного забезпечення до використання даних зразків техніки [1].

Взагалі, сам процес технічного діагностування в ДПСУ, як такий - відсутній, $€$ тільки окремі напрями та форми з яким працює персонал. Відомо що сучасний транспортний засіб має достатньо велику кількість електронних систем, як в двигунах так і в інших системах автомобілів. Тому для якісного обслуговування транспортних засобів та забезпечити непереривний, якісний процес охорони Державного кордону, необхідно впроваджувати сучасні системи технічного діагностування в структурні підрозділи дПСУ, адже відомо що діагностування транспортних засобів безпосередньо впливає на процес прогнозування ресурсу експлуатації даної техніки. Тому без якісного діагностування сучасної техніки, неможливо вчасно виявити приховані несправності, які у майбутньому впливатимуть на процес охорони Державного кордону. Другою складової цього процесу є зменшення витратної частини на придбання запасних частин автомобілів, адже мета технічного діагностування - виявлення порушень технічного стану та несправностей, які в майбутньому впливатимуть на роботу систем, які відповідають за працездатний стан автомобіля в цілому [2].

Тому в сучасному інформаційному суспільстві, де одну з найважливіших функцій виконує комп'ютер, де сучасний транспортний засіб обладнано кількома системами які працюють на основі електронних сигналів комп'ютерної техніки - логічним $€$ впровадження системи технічного діагностування, яка б давала можливість не тільки контролювати технічний стан транспортних засобів але й експлуатаційні показники. Сама система повинна базуватись на впровадження в підрозділи сучасного діагностичного обладнання та програмного забезпечення, за допомогою якого автомобільна служба могла б вчасно провести діагностування та технічне обслуговування.

Практика показала, що невчасна відмова однієї з систем автомобільної техніки, призводить до погіршення моніторингу ситуації на Державному кордоні, невчасне прибуття оперативно-розшукових груп на місця де були виявлені ознаки порушення Державного кордону і як наслідок погіршення внутрішньої ситуації в країн, шляхом збільшення товарів які потрапили незаконним шляхом. Ще однією ознакою стало те що з почасту АТО на сході країни, групами ДПСУ та СБУ постійно виявляються схорони зброї, яка потім використовується для дестабілізації ситуації в країні. Тому актуально $є$ потреба розробка інтегрованої системи технічного діагностування зразків техніки в ДПСУ, яка здатна оперативно оцінювати теперішній стан автомобіля та надає можливість прогнозувати експлуатації у майбутньому. 


\section{Список використаних джерел:}

1. Sivak V. (2015). Koncepciya bezpechnoyi ekspluataciyi transportny 'x zasobiv v umovax oxorony' derzhavnogo kordonu. [The concept of safe operation of vehicles in conditions of state border protection Collection of scientific works of the National Academy of State Border Guard Service of Ukraine. № 2. pp. 204-211.

2. Vorobjov O., Korehov A. (2016). Obgruntuvannya neobxidnosti pokrashhennya kontrolyu texnichnogo stanu transportnyx zasobiv za raxunok udoskonalennya systemy texnichnoyi diagnostyky. [Substantiation of the need to improve the control of the technical condition of vehicles by improving the system of technical diagnostics]. Collection of scientific works of the National Academy of State Border Guard Service of Ukraine.

\section{DOI 10.36074/29.11.2019.v3.03}

\section{ПРОБЛЕМЫ РАЗВИТИЯ ВЕТРОЭНЕРГЕТИКИ}

\section{Зарипова Адэлина Маратовна}

степень бакалавра, студент

Федеральное государственное бюджетное образовательное учреждение высшего образования «Московский политехнический университет»

Владимиров Сергей Николаевич

кандидат технических наук, доцент

Федеральное государственное бюджетное образовательное учреждение высшего образования «Московский политехнический университет»

РОССИЙСКАЯ ФЕДЕРАЦИЯ

Ежедневно во всем мире расходуется колоссальное количество электроэнергии, и с каждым новым днем глобальное потребление электричества все больше и больше. Это ведет к быстрым сокращением органического топливу, таких как уголь, нефть и газ. По последним данным мировой запас нефти составляет 1,726 трлн баррелей, которых хватит при нынешнем уровне потребления на 53 года. Помимо сокращения природных ресурсов, выбросы при сжигании органического топлива приводят к ухудшению состояния окружающей среды. Решением этих проблем является освоение и внедрение возобновляемые и экологически чистых источников энергии. Одной из перспективной альтернативы традиционному топливу является ветроэнергетика.

За последние два десятилетия в мире альтернативная энергетика приобрела большую популярность, в первую очередь ветроэнергетика. Повышение цен на традиционное топливо и неуверенность в стабильности, и ненадежности в поставках привело к беспокойству среди стран импортеров энергоресурсов. Это в первую очередь стало причиной возрастания интереса к вопросу экономической эффективности использования возобновляемых источников энергии. Западные страны, стремящиеся к энергонезависимости, активно инвестируют инновационные разработки в этой области и вкладывают огромный средства в развитие ветряных электрических установок. В 2015 году в Великобритании, как и в Германии, ветроэнергия стала самой дешевой в стране, так как Соединённое Королевство является 
самым обдуваемым местом в Европе. С недавних пор альтернативная энергетика является абсолютно конкурентоспособной ископаемому топливу.

Быстрая индустриализация СССР, развитие электрификации, наличие дешевого ископаемого топлива и рост «гигантов советской энергетики» отодвинули малую энергетику на периферию отрасли. Всплеск интереса к возобновляемым источникам энергии и широкое внедрение их в практику во время мировых топливных кризисов Россию почти не задели в силу ее обеспеченности собственными топливными ресурсами. Поэтому Россия во всемирной таблице развития ветроэнергетики находится где-то после номера 34 в окружении таких стран, как Тунис, Израиль, Иран. Из изложенного видно, что Россия стоит в самом начале пути к использованию энергии ветра [1].

Обжитая часть России бедна ветровыми ресурсами. Средняя скорость ветра в промышленных районах составляет 4-5 м/с. Малая скорость ветра означает малую мощность ветрового потока. К ветрообильным районам можно отнести побережье Северного Ледовитоко океана, побережье Тихого океана, но они мало обжиты, поэтому создание ветряных электростанций в этой местности представляет сложность. Морское побережье Ростовской области и Краснодарского края имеют хороший ветряной потенциал, так же эти края являются благоприятными для развития автономной малой ветроэнергетики. Стационарная ветрогенератор не только снизит затраты на электроэнергию, но $и$ позволит решить проблемы обеспечения электроэнергией труднодоступные места России, где еще не проведена электросеть. Для бесперебойной работы электричества можно накапливать в аккумуляторные батареи необходимый ресурс электроэнергии для применения в периоды отсутствия ветра или сочетать ветрогенераторы с солнечными панелями [2].

$\mathrm{Ha}$ данный момент используется большое количество разных по конструкции ветрогенераторов, однако не все используются в промышленных масштабах. К ним относятся классический горизонтальный ветрогенератор, многолопастный ветрогенератор, ротор Савониуса, ротор Дарье и ортогональный ротор. Принцип работы классического горизонтального ветрогенератора основан на подъемной силе. Ветер под углом дует на плоскую сторону лопасти, из-за этого создается разница в давлении, которая создает подъемную силу. Принцип работы многолопастного ветрогенератора такой же, однако он имеет до пятидесяти лопастей. Вращение ротора Савониуса происходит за счет сил сопротивления, вызывающих из-за геометрического строения лопастей. Ротор Дарье на тонких, выглядящих как длинные изогнутые пластины, несущих поверхностях, имеющих аэродинамический профиль, вращающий момент создается подъемной силой. Ортогональный ротор похож по конструкции на ротор Дарье, но в нем используются прямые вертикальные аэродинамические лопасти, напрямую связанные с валом.

В основном говоря о достоинствах и недостатках ветрогенераторов разных конструкций, принимается во внимание различие между ветрогенераторами с вертикальной и горизонтальной осью вращения. Недостаток вертикальных ветрогенераторов тихоходность, поэтому они вырабатываю меньше энергии, но их виброшумовое загрязнение в разы меньше чем у горизонтальных. Однако у вертикальных конструкций коэффициент использования ветра выше, поэтому такие генераторы можно устанавливать на крыше частного дома без ущерба для конструкции и здоровья людей. В свою очередь 
горизонтальные ветрогенераторы более быстроходные и вырабатывают большее количество энергии при одинаковых условиях эксплуатации. Если же говорить про другие различия, то разные конструкции вертикальных генераторов не имеют существенных различий.

Изложенное выше позволяет говорить о том, что присущие ветроэнергетике проблемы хотя и нуждаются в решении, но в целом не уменьшают ее достоинства, связанных прежде всего с сокращением потребления ископаемых видов топлива и вредных выбросов в атмосферу [1]. Так что использования ветроэнергетики является перспективным будущим для России, поскольку она имеет для этого большой потенциал.

\section{Список использованных источников:}

1. Дмитриев, Г. С. (2004). Что несет с собой развитие ветроэнергетики. Энергия, (8), 11-19.

2. Германович, В. \& Турилин, А. (2011). АЛЬТЕРНАТИВНЫЕ ИСТОЧНИКИ ЭНЕРГИИ. Практические конструкции по использованию энергии ветра, солнца, земли, биомассы. СПб.: Наука и Техника.

\section{ПРОМИСЛОВЕ ОТРИМАННЯ БАРВНИКІВ ДЛЯ ТРИАДИ ПЕРЕВОДНОГО ТЕРМОДРУКУВАННЯ НА ТКАНИНАХ 3 ПОЛІЕФІРНИХ СИНТЕТИЧНИХ ВОЛОКОН}

\footnotetext{
НАУКОВО-ДОСЛІДНА ГРУПА:

Вигоняйло Олександр Іванович Інститут хімічних технологій Східноукраїнського національного університету ім. В. Даля Попов Євген Вадимович доктор технічних наук, професор Інститут хімічних технологій Східноукраїнського національного університету ім. В. Даля

Мороз Олексій Валерійович кандидат технічних наук Інститут хімічних технологій Східноукраїнського національного університету ім. В. Даля УКРАÏHA

В даному повідомленні наводяться результати дослідження синтезу триади термопереводних барвників (алого, жовтого і синього кольорів) для приготування сумішевих з доступних за ціною напівпродуктів і компонентів, що виділені з коксового газу і смоли після коксування кам'яного вугілля. Виділенні і очистку компонентів з коксового газу і смоли здійснювали за опублікованими [1-4] рекомендаціями.

Згадані триадні барвники широко застосовуються для отримання випускних форм порошків різних сумішевих кольорів, в тому числі чорного (контурного) для фрарбування віскозних, шовкових тканин, приготування поліграфічних фарб для шпалер на папері з послідуючим термодрукуванням на поліефірних тканинах, нетканих матеріалах та ін. виробів, у виробництві водоемульсійних лакофарбових композицій для художніх фрарб [5-7]. Контроль технологічних процесів проводили по методиках [8].
} 


\section{1. Синтез моноазобарвнику алого Ж термопереводного.}

(Disperse Red C.I. 1) [9, c. 658-659] проводили діазотуванням п-нітроаніліну при температурі від 0 до минус $(2-3)^{\circ} \mathrm{C}$ протягом 13 год, фрільтруванням діазорозчину та сполученням його з попередньо отриманим $\mathrm{N}$-етил- $\mathrm{N}-\beta-$ етиланіліном протягом 24 год. при $0-2^{\circ} \mathrm{C} \quad 3$ подальшими стадіями фільтрування, промивання охолодженою до цієї ж температури водою від солей і сушіння. Вихід барвника в перерахунку на п-нітроанілін становить $98,1 \%$.

Вихідними компонентами був виділений із коксового газу та смоли i очищений анілін після коксування кам'яного вугілля, 3 якого спочатку синтезували п-нітроанілін (він же азоамін червоний Ж) з послідуючими операціями його діазотування і сполучення з $\mathrm{N}$-етил- $\mathrm{N}-\beta$-етиланіліном.

Отримання з аніліну діазотованого п-нітроаніліну.

Отримання 3 аніліну п-нітроаніліну та його діазотування здійснювали проведенням наступних реакцій за рівняннями:
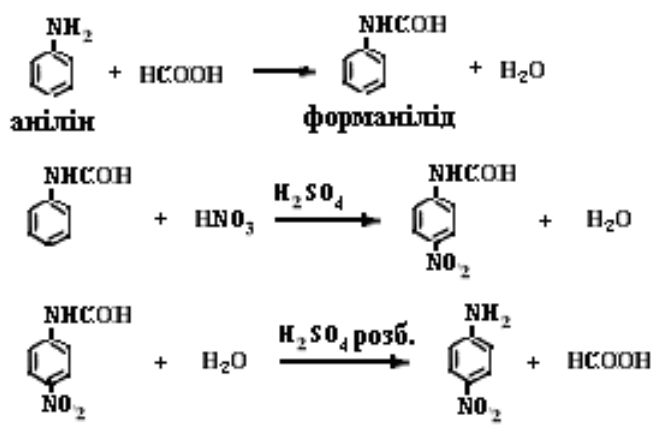

n-кітроанілік

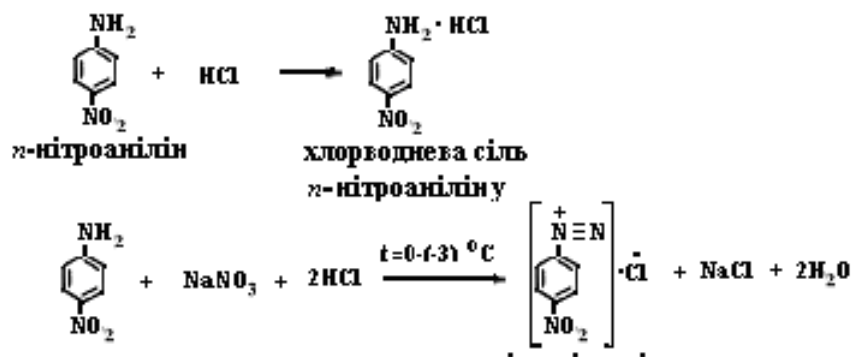

сіль дізания

n-нітроангіліну

\section{Отримання з аніліну N-етил-N- $\beta$-оксіетиланіліну.}

Отримання $\mathrm{N}$-етил- $\mathrm{N}-\beta$-оксіетиланіліну здійснювали температурною конденсацією етилхлориду 3 очищеним аніліном коксового газу 3 послідуючою взаємодією отриманої сполуки 3 моноетаноламіном в спиртовому з середовищі за рівняннями: 


$$
\begin{aligned}
& \mathrm{B}^{-\mathrm{NH}_{2}}+\mathrm{C}_{2} \mathrm{H}_{4} \mathrm{CO} \longrightarrow \mathrm{C}_{2}^{\mathrm{H}}+\mathrm{HCO}
\end{aligned}
$$

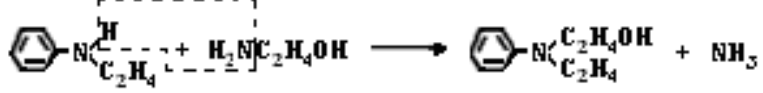

$$
\begin{aligned}
& \mathrm{HCl}+\mathrm{NH}_{3} \rightarrow \mathrm{NH}_{4} \mathrm{Cl} \text {. }
\end{aligned}
$$

\section{Отримання термопереводного моноазобарвнику алого Ж з аніліну i N-етил-N- $\beta$-оксіетиланіліну.}

Отримання термопереводного моноазобарвнику алого $Ж$ здійснювали сполученням солі діазонія п-нітроаніліну з $\mathrm{N}$-етил- $\mathrm{N}$ - $\beta$-оксиетиланіліном при температурі $3-5^{\circ} \mathrm{C}$ впродовж 12 год за рівняннями:

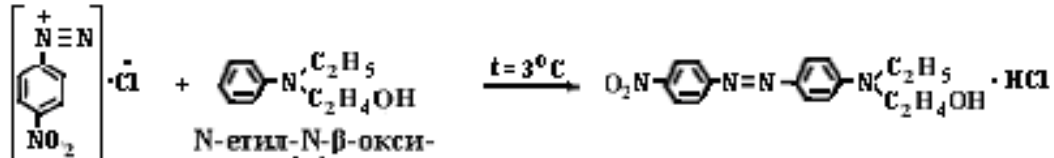

$$
\begin{aligned}
& \text { етитанілін }
\end{aligned}
$$

$$
\mathrm{HCl}+\mathrm{NaOH} \rightarrow \mathrm{NaCl}+\mathrm{H}_{2} \mathrm{O}
$$

з подальшим фрільтруванням при цій же температурі і після фрільтрування нейтралізуванням при $20-25^{\circ} \mathrm{C}$ водним розчином соди:

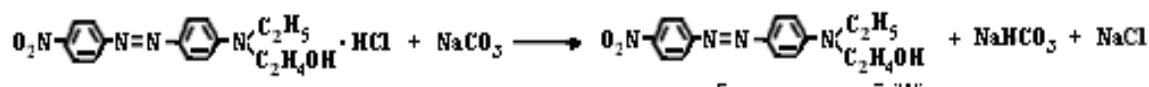

$$
\begin{aligned}
& \text { моноззобарвню口 алюй Ж }
\end{aligned}
$$

промиванням і передачею водної пасти для приготування випускної форми для отримання термопереводної фрарби червоного кольору 3 жовтуватим відтінком.

Допоміжні стадії включають:

- приготування 28-30\%-ного розчину нітриту натрію;

- уловлювання відходячих газів в скрубері.

Нижче на рис. 1 приведена технологічна схема отримання термопереводного моноазобарвнику алого Ж.

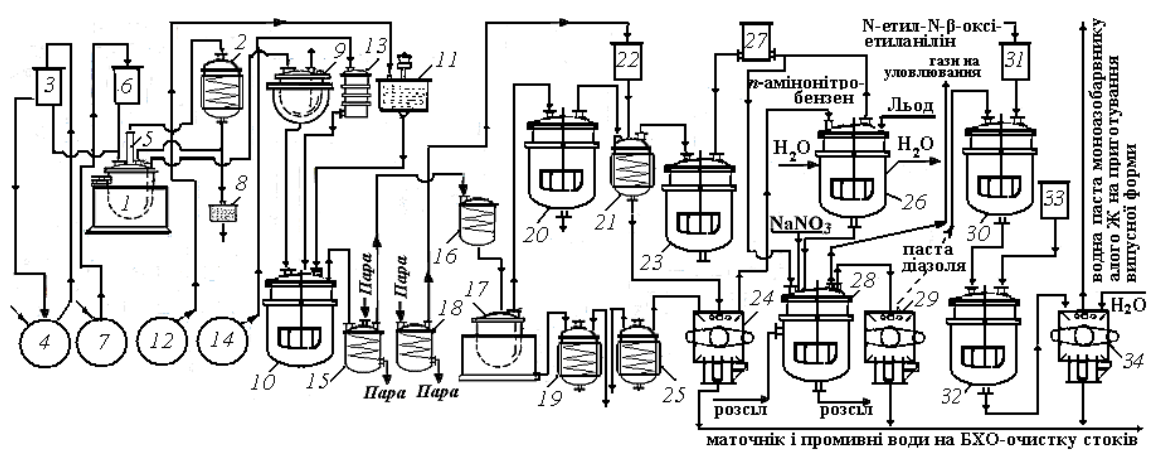

Рис. 1. Схема виробничого отримання термопереводного моноазобарвнику алого Ж з очищеного аніліну після коксування кам'яного вугілля: 
1 - формілятор; 2 - холодильник; 3 - мірник для аніліну; 4 - монтежю для аніліну; 5 - десрлегматор; 6 - мірник для мурашиної кислоти; 7 - монтежю для мурашиної кислоти; 8 - пастка, 9 - мірник для фрорманіліду: 10 - нітратор; 11 мірник для моногідрату; 12 - монтежю дла моногідрату; 13 - мірник для азотної кислоти; 14 - монтежю для азотної кислоти; 15 - монтежю для нітромаси; 16 апарат для виділення нітроформаніліду; 17 - фрільтрувальний апарат для нітроформаніліду; 18 - монтежю для відпрацьованої кислоти; 19, 25 - монтежю для промивної води; 20 - суспензатор; 21 - омилювач; 22 - мірник для відпрацьованої кислоти; 23 - апарат для уловлювання кислоти; 24 - фільтрувальний апарат для п-нітроаніліну; 26 - монтежю для маточника і промивних вод; 27 - мірник для хлорводневої кислоти; 28 - апарат для діазотування п-нітроаніліну; 29 фрільтрувальний аппарат для фрільтрування діазоля; 30 - апарат для сполучення $i$ отримання барвнику; 31 - мірник для $N$-етил- $N$ - $\beta$-оксіетиланіліну; 32 - апарат для нейтралізування барвнику розчином HCl; 33 - мірник для водного розчину лугу; 34 фольтрувальний аппарат для фрільтрування суспензії моноазобарвнику алого Ж.

\section{Опис технологічної моноазобарвнику алого Ж. \\ схеми синтезу термопереводного \\ Формилювання аніліну. Формилювання аніліну проводиться для захисту} аміногрупи від окисляючої дії азотної кислоти при нітруванні. Формилювання проводили в алюмінієвому обигріваємому топковими газами апараті 1 (формиляторі), забезпеченому сорочкою для охолодження водою, дефлегматором 5 i алюмінієвим змійовиковим холодильником 2. Анілін завантажували в формилятор 3 мірника 3, в який його передавлювали 3 монтежю 4. Мурашину кислоту наливали в формилятор з мірника 6 , в який її передавливали 3 алюмінієвого монтежю 7. Анілін і мурашину кислоту перемішували стисненим повітрям, нагрівали до кипіння і кип'ятили протягом однієї години. При цьому холодильник 2 включали як зворотний. Після цього з формилятора відбирали пробу для визначення кількості непрореагованих аніліну та мурашиної кислоти. При підвищеному вмісті в пробі одного $з$ реагентів до реакційної маси придавали розраховану кількість іншого реагенту і кип'ятили ще деякий час.

По закінченні формилирования холодильник 2 вмикали як прямий і поступово підвищували температуру. При цьому відганяла воду i непрореаговану мурашину кислоту, що утворилися при реакції. Потім для відгонки непрореагованого аніліну апарат приєднували через пастку 8 до вакуумного трубопроводу i продовжували нагрівання. Після відгонки відбирали пробу для визначення якості отриманого форманіліду. Готовий розплавлений форманілід передавлювали стисненим повітрям в мірник 9 , забезпечений сорочкою для підігрівання парою. Підігрівання необхідно, щоб уникнути застигання форманіліду, який плавиться при температурі $45^{\circ} \mathrm{C}$.

Нітрування форманіліду. Нітрування форманіліду проводили в чавунному нітраторі 10 , забезпеченому пропелерною мішалкою і сорочкою для охолодження. 3 монтежю 12 моногідрат передавлювали в мірник 11 i звідти - в нітратор, охолоджували розсолом і завантажували з мірника 9 форманілід по трубі, яка обігрівається парою. Після нетривалого перемішування форманілід повністю розчиняється В моногідраті. В охолоджений розсолом розчин приливали з мірника 13 азотну кислоту, яку передавлювали в мірник з монтежю 14. Азотну кислоту придавали з такою швидкістю, щоб температура маси не підвищувалася.

Після придавання азотної кислоти нітромасу розмішували при температурі $0-(-2)^{\circ} \mathrm{C}$ і відбирали пробу для визначення кількості непрореагованого форманіліду. Низька температура при нітруванні форманіліду необхідна, щоб 
уникнути відщеплення формильної групи, яка захищала аміногрупу від окислення азотною кислотою. Готову нітромасу передавливали з нітратора в чавунний монтежю 15.

Виділення п-нітроформаніліду. Виділення п-нітроформаніліду здійснювали в сталевому футерованому апараті 16 , обладнаному мішалкою і свинцевим змійовиком для охолодження розсолом. В апарат наливали воду, охолоджували її і повільно передавливали нітромасу 3 монтежю 15, регулюючи швидкість подачі нітромаси і розсолу в змійовик з таким розрахунком, щоб температура весь час трималася однаковою.

Виділення 3 розчину п-нітроформаніліду здійснювали розбавленням нітромаси водою. Підвищення температури може призводити до часткового омилення п-нітроформаніліду і розчинення утвореного п-нітроаніліну в сульфатній кислоті і втрачати продукту в маточному розчині.

Суспензію п-нітроформаніліду спускали 3 апарата 16 через фільтрувальний апарат 17. Щоб уникнути омилення п-нітроформаніліду суспензію швидко відфільтровували, а фрільтрат направляли в сталевий футерованих монтежю 18, а 3 нього - в мірник 22, який частково використовували для омилення п-нітроформаніліду. Осад п-нітроформаніліду промивали на фільтрі холодною водою до зникнення кислої реакції в нижніх шарах осаду. Промивну воду через монтежю 19 спускали по каналізації на очистні споруди підприємства. Після промивання п-нітрофрорманілід розбавляли на фільтрі водою до стану суспензії і відсмоктували вакуумом через верх друк-фільтра в суспензатор 20.

Омилення п-нітроформаніліду. Омиляли п-нітроформанілід шляхом нагрівання з розбавленою сульфатною кислотою в сталевому футерованому апараті (омилителі) 21, обладнаному мішалкою, змійовиком із неїржавіючої сталі і паровим барботером. Суспензію п-нітроформаніліду передавливали з суспензатора 20 в омилитель, розбавляли водою і обережно, щоб уникнути спінювання, нагрівали глухою і гострою парою. Потім з мірника 22 добавляли відпрацьовану сульфатну кислоту, доливали воду, нагрівали глухою парою і відбирали пробу для визначення кінця омилення. Омилення вважали закінченим, якщо реакційна маса повністю розчинялася в соляній кислоті. В іншому випадку продовжували нагрівання.

По закінченні омилювання масу в апараті, поступово охолоджували водою, зупиняли мішалку і сифонували відстояну рідину по шлангу через фільтр-пастку 23. Масу, що залишилася в апараті, розбавляли водою, нагрівали при розмішуванні гострою і глухою парою для розчинення утвореного о-нітроаніліну і потім охолоджували.

Фільтрування п-нітроаніліну. В результаті омилення п-нітроанілін, що утворився, відфільтровували на сталевому футерованому фільтр-апараті 24 . через фрільтрувальний матеріал - бельтинг і промивали підігрітою до $50^{\circ} \mathrm{C}$ водою. Кінець промивання визначали по температурі плавлення пнітроаніліну $\left(146-147^{\circ} \mathrm{C}\right)$ і його водну пасту під назвою «азоамін червоний Ж» передавали на стадію отримання хлоргідрату п-нітроаніліна в апарат 26. Матковий розчин і промивні води направляли в монтежю 25 і далі - в каналізацію на очистку.

Отримання хлоргідрату п-нітроаніліну та його діазотування.

Хлоргідрат п-нітроаніліну отримували в апараті 26, куди завантажували водну пасту, воду і хлорводневу кислоту з мірника 27 і перемішували при температурі навколишнього середовища впродовж 7 год, після чого у хлорводневу сіль п-нітроаніліну, що утворилася, добавляли попередньо 
охолоджений до температури 0-(-3) ${ }^{\circ} \mathrm{C}$ розчин нітрату натрію протягом 13 год. Утворений розчин діазонієвої солянокислої солі п-нітроаніліну (диазоля алого Ж) з виходом по стадії $97 \%$ за рівняннями:

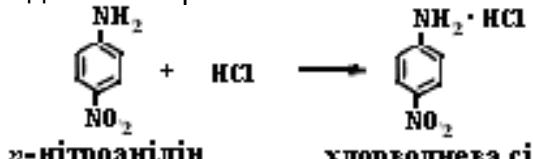

хлорводнева сіль n-нітроаніліну

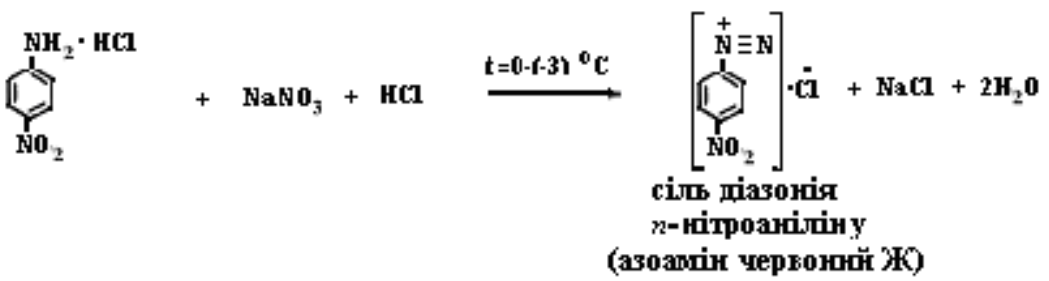

і вивантажували з фрільтрувального апарата 29 при перемішуванні в апарат 30 для сполучення з $\mathrm{N}$-етил- $\mathrm{N}-\beta$-оксіетиланіліном.

\section{Отримання термопереводного моноазобарвнику алого Ж з аніліну} i $N$-етил- $N$ - $\beta$-оксіетиланіліну

Отримання термопереводного моноазобарвнику алого Ж (Disperse Red C.I. 1) здійснювали в апараті 30 сполученням солі діазонію п-нітроаніліну з Nетил-N- $\beta$-оксіетиланіліном (він же оксиетилетиланілін), що подається 3 мірника 31 при температурі $3-5^{\circ} \mathrm{C}$ впродовж 12 год за рівняннями:

$$
\left[\begin{array}{c}
\mathrm{NO}_{2} \\
\mathrm{~N}_{1}^{+} \equiv \mathrm{N}
\end{array}\right] \cdot
$$

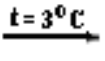<smiles>[Z11]CN(CC)c1ccc(N=Nc2ccc([N+](=O)[O-])cc2)cc1</smiles>

\section{N-етит-N-B-oксi- eтнтанiлiн}

$$
\mathrm{HCl}+\mathrm{NaOH} \rightarrow \mathrm{NaCl}+\mathrm{H}_{2} \mathrm{O}
$$

з подальшим нейтралізуванням в апараті 32 при $20-25^{\circ} \mathrm{C}$ водним розчином лугу або соди з мірнику 33 і фільтруванням при цій же температурі на фільтрувальному обладнанні 34 за рівняннями:
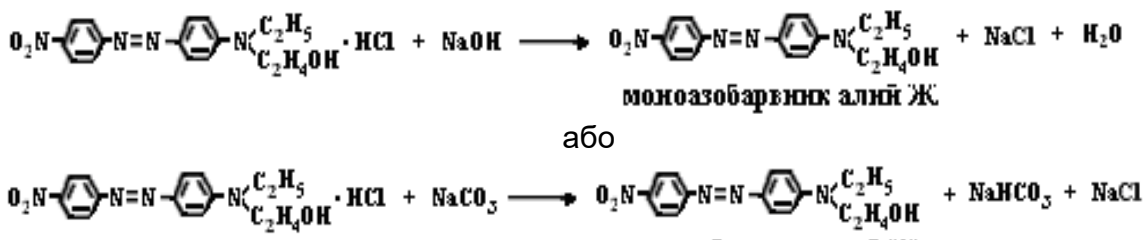
моноазобарвюе алюй Ж

промиванням і передачею водної пасти для приготування випускної форми для отримання термопереводної фрарби червоного кольору 3 жовтуватим відтінком.

Допоміжні стадії включають:

- приготування 28-30\%-ного розчину нітриту натрію; 
- уловлювання в скрубері газів, що відходять, при реакціі діазотування

- отримання $\mathrm{N}$-етил- $\mathrm{N}-\beta$-оксиетиланіліну.

За аналогічною технологією з діазотованого п-нітроаніліну і $\mathrm{N}$-етилціан- $\mathrm{N}$ $\beta$-етиланіліном отримується термопереводний моноазобарвник оранжевий (Disperse Orange C.I. 25) [9, с. 654-655] за схемою реакцій:

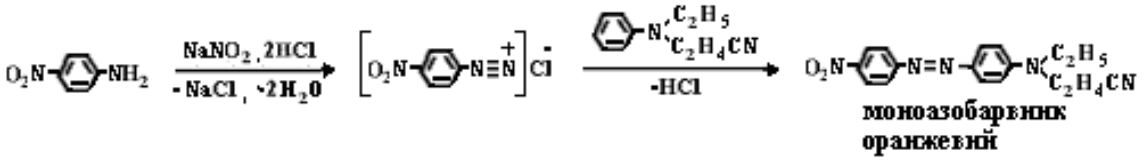

Для азосполучення $\mathrm{N}$-етилціан-N- $\beta$-етиланілін синтезували послідовною взаємодією аніліну коксового газу з акрилонітрилом при $108-115^{\circ} \mathrm{C}$ в присутності хлористого цинку і гідрохінону з подальшою стадією етилювання утвореного $\mathrm{N}$ - $\beta$-ціанетиланіліну етаноламіном до утворення $\mathrm{N}$-етил- $\mathrm{N}-\beta$ ціанетиланіліну за схемою:

$$
\begin{aligned}
& \mathrm{B}_{2} \mathrm{C}=\mathrm{CH}-\mathrm{CN} \\
& \text { пірохинон, }
\end{aligned}
$$

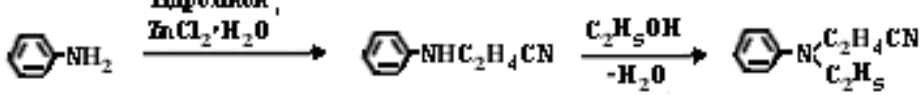

з подальшою очистною фільтрацією і передачею на стадію отримання моноазобарвнику оранжевого кольору азосполученням з п-нітроаніліном.

2. Синтез моноазобарвнику жовтого 3 термопереводного (Disperse Yellow C.I. 3) [9, c. 654-655] проводили діазотуванням оцет-п-фенілендіаміну при температурі $0-(+2)^{\circ} \mathrm{C}$ протягом 11 год, фрільтруванням діазорозчину та сполученням його при 5-6 ${ }^{\circ} \mathrm{C}$ в лужному середовищі з попередньо отриманим лужним розчином крезолята натрію за рівняннями:

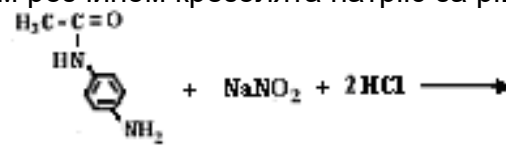

ощет- $n$-фенілен-

діамін

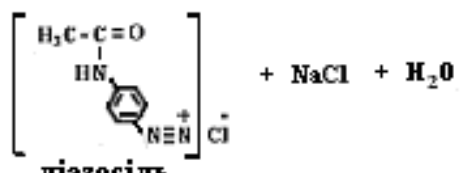

діазосіль

оцет- $n$-фенілен-

піаміку

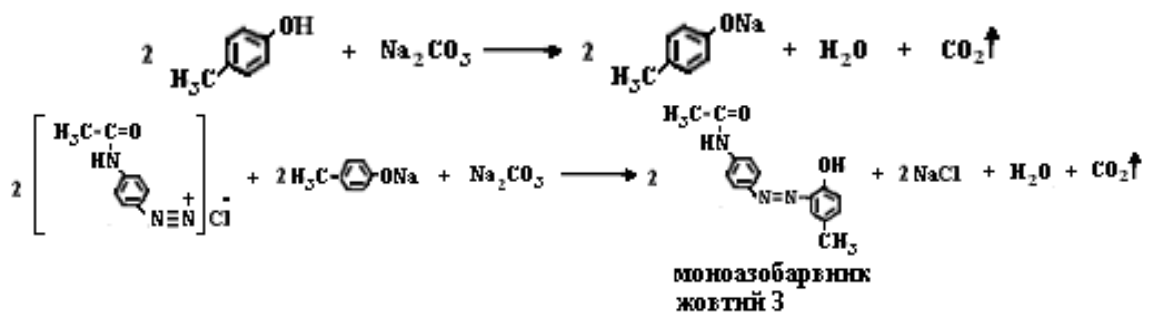

з послідуючими операціями фільтрування, промивки водою і пасти барвнику для приготування термопереводної фарби жовтого кольору. Вихід складає $87 \%$ в розрахунку на ацет-п-фенілендіамін.

Допоміжні стадії включають: приготування 28-30\%-ного розчину нітриту натрію; приготування розчину крезоляту натрію; уловлювання відходячих газів в скрубері. 
32 - Problèmes et perspectives d'introduction de la recherche scientifique innovante $\bullet$ Volume 3

3. Синтез барвнику дисперсного синього Ч термопереводного (Disperse Blue C.I. 3, № 61505) [9, с. 679-680] здійснювали з виділеного i очищеного антрахінону коксової смоли після коксування кам'яного вугілля, 3 якого спочатку синтезували хінізарин і лейко-1,4-діаміноантрахінон та одночасним конденсуванням їх монометиламіном і моноетаноламіном в спиртовому середовищі. При цьому утворювалися барвник дисперсний синій 4 і лейко-сполука, яку окисленням киснем повітрям в присутності оцтовокислої міді в якості каталізатора також переводили в барвник дисперсний синій Ч з послідуючими операціями відгонки метилового спирту. Далі барвник передавали на диспергування в бісерному млині до розміру часточок в інтервалі 3-5 мкм і після відділення бісеру використовували для приготування флексографської фрарби для друкування на паперу.

Отримання з нафталіну хінізарину і лейко-1,4-діаміноантрахінону

Отримання хінізарину (він же 1,4-діоксиантрахінон) здійснювали з очищеного нафрталіну коксової смоли після коксування кам'яного вугілля по нижче приведеній

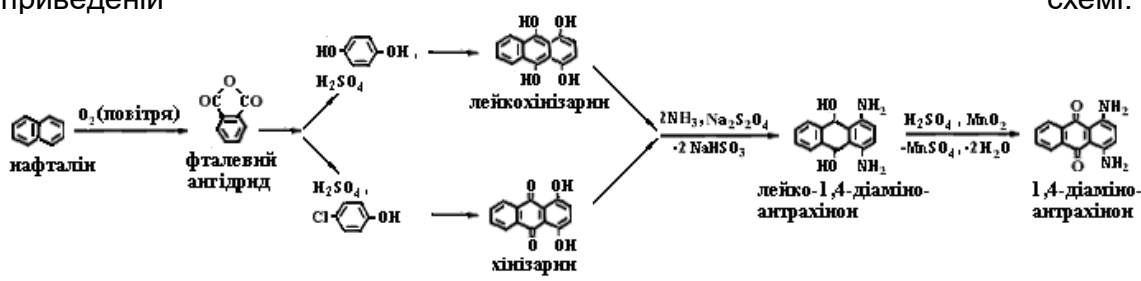

Подальше амінування лейкохінізарину і хінізарину приводить до утворення лейко-1,4-діаміноантрахінону. Якщо його окислювати в сірчанокислому середовищі піролюзитом при $95^{\circ} \mathrm{C}$ протягом двох діб, віділяється термопереводний антрахіноновий барвник фіолетовий Ч (Disperse Violet C.I. 1, № 61100) [9, c. 676-677].

Часткове окислення лейкохінізарину і хінізарину в сірчанокислому середовищі піролюзитом при $70^{\circ} \mathrm{C}$ протягом півтори доби приводить до утворення 1-окси-4-аміноантрахінону - антрахіноновому барвнику червоному 2C (Disperse Red C.I. 15, № 60710) [9, c. 662] з виходом 96\% в розрахунку на лейко-1,4-діаміноантрахінон за рівняннями:

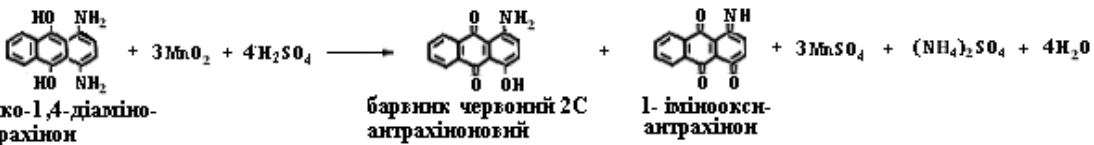
тейово-1 4-діаміно антрахінон

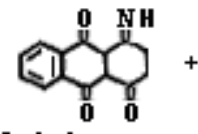

1- іміноo⿰chантрахінон

$\mathrm{NaHSO}_{3}+\mathrm{H}_{2} \mathrm{O}$ $\mathrm{MnO}_{2}+2 \mathrm{NaHSO}_{3}+\mathrm{H}_{2} \mathrm{SO}_{4}$

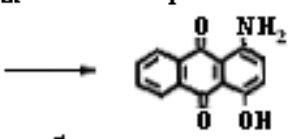

барвнок червонй $2 \mathrm{C}$ антрахіноновй
$+\mathrm{NaHSO}_{4}$

$$
\rightarrow \mathrm{MnSO}_{4}+\mathrm{NaHSO}_{4}+\mathrm{H}_{2} \mathrm{O} \text {. }
$$

Однак він не є термопереводним барвником і використовується для фрарбування у ванні ацетатного шовку, поліамідних і поліефрірних волокон. 
Конденсація хінізарину та лейко-1,4-діаміноантрахінону 3 монометиламіном і моноетаноламіном

Конденсацію хінізарину та лейко-1,4-діаміноантрахінону 3 монометиламіном і моноетаноламіном проводили в спиртовому середовищі (метанолі) при $(92 \pm 2)^{\circ} \mathrm{C}$ протягом 11 год (з виходом по стадії 96,9\%) за рівнянням:

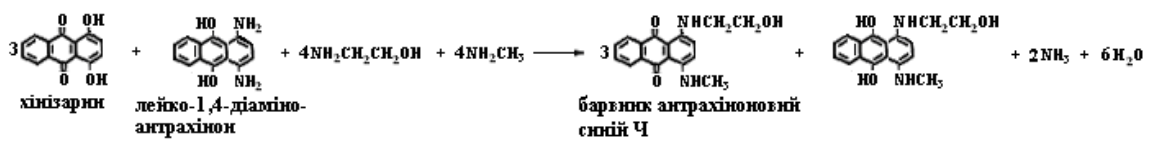

Побічними продуктами синтезу в незначної кількості $€$ 4диметиламіноантрахінон і 1,4-діоксиетиламіноавнтрахінон.

Окислення лейкосполуки в барвник антрахіноновий синій ч

Окислення отриманої лейкосполуки киснем повітрям при $65-70^{\circ} \mathrm{C}$ протягом 5 год в присутності оцтовокислої міді в якості каталізатора виділявся антрахіноновий термопереводний барвник синій Ч за рівнянням:

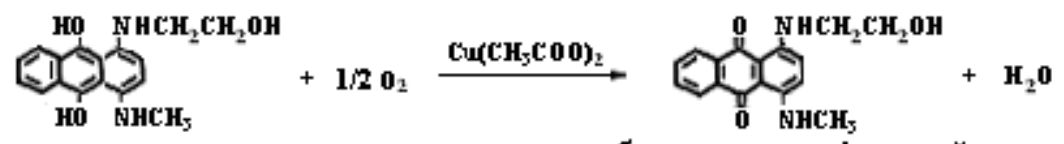

\section{барвю口о антрахіноновнй снपій प}

з послідуючими операціями відгонки метилового спирту і приготування випускної форми барвнику диспергуванням водної суспензії в бісерному млині.

На рис. 2 приведені спектри відбиття стандартних рівнів інтенсивності (а) рентгенограми (б) зразків синтезованих термопереводних барвників, що відносяться до триади утворення різнокольорових сумішів - алого Ж (Disperse Red C.I. 1), жовтого 3 (Disperse Yellow C.I. 3) і синього Ч (Disperse Blue C.I. 3, № 61505).
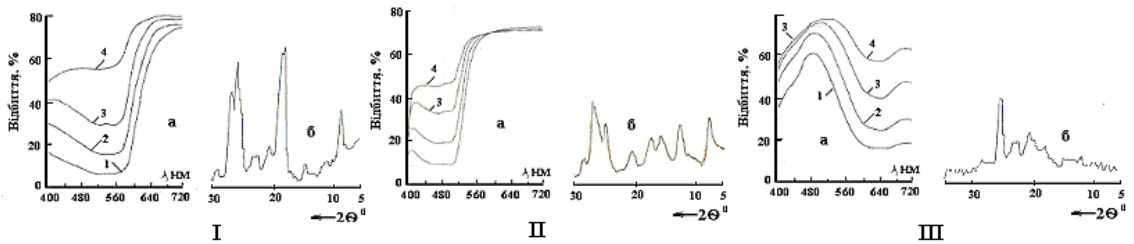

Рис. 2. Спектри відбиття стандартних рівнів інтенсивності:

1 - 1:3; 2 - 1:9; 3 - 1:25; 4 - 1:200 (a) та рентгенограми (б) зразків синтезованих барвників алого Ж (I), жовтого 3 (II) і синього 4 (III). $2 \theta^{\circ}$ - кут Брега 3 рентаенограми. 
34 • Problèmes et perspectives d'introduction de la recherche scientifique innovante $\bullet$ Volume 3

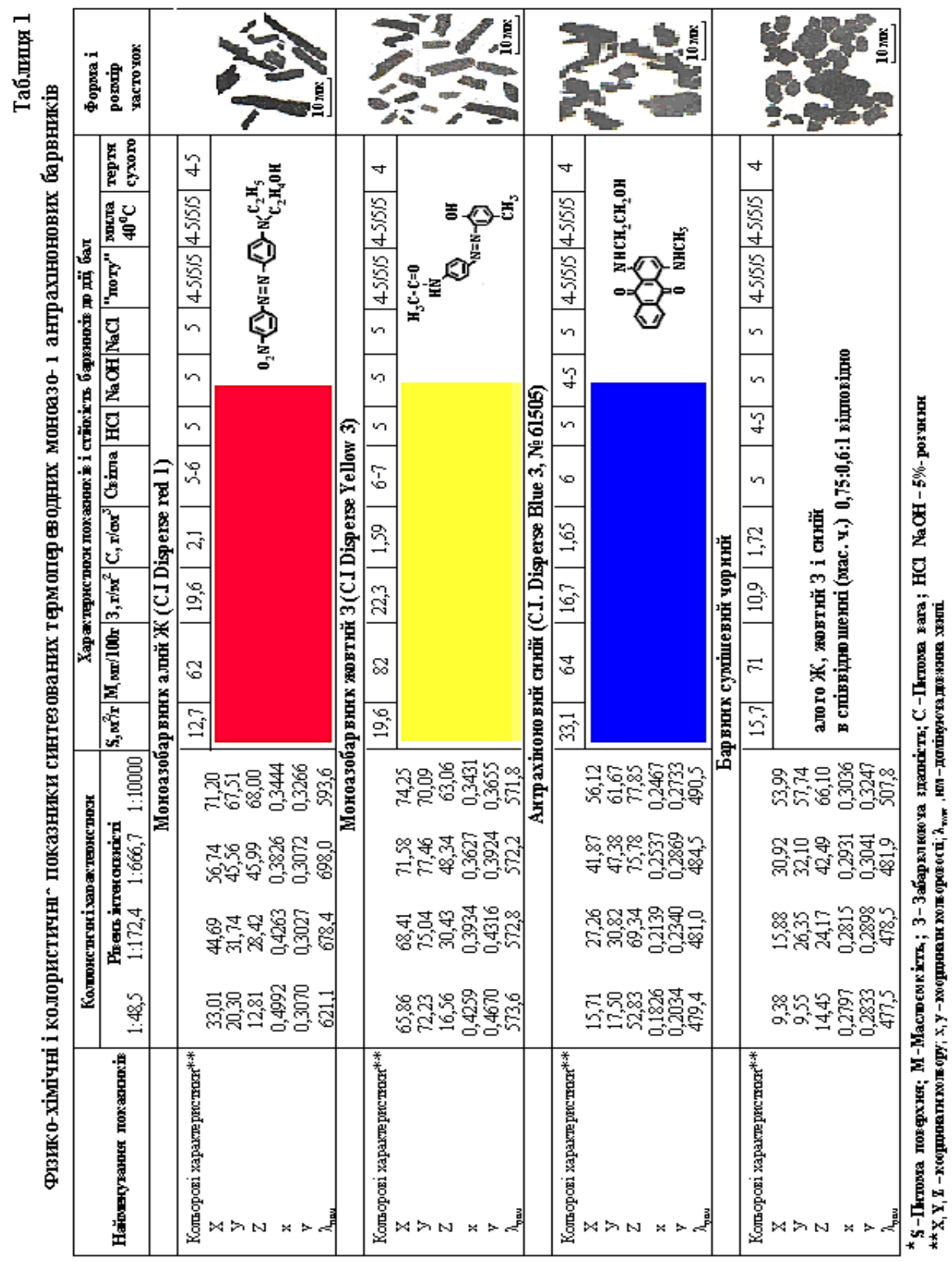


3 синтезованої тріади барвників алого Ж, жовтого 3 і синього 4 отримується також сумішевий барвник контурного чорного кольору, показники якості якого охарактеризовані нижче в табл. 1. Як видно з табл. 1, барвники по ДСТУ 9733 мають високі показники якості до різних видів дій.

Висновки. Розглянуто технологічні особливості синтезу тріадних барвників з метою створення фрарб широкої колірної гами для переводного термодрукування по поліефірній тканини. Досліджено колористичні властивості синтезованих барвників, визначено їх колористичні властивості, інтенсивності при їх термопереході з паперу на поліефрірну тканину і стійкість барвників на зафрарбовуваній тканині до фрізико-хімічних впливів (світла, «поту», мила, тертя та ін. дій).

\title{
Список використаних джерел:
}

1. Гоголева, Т.Л., Шустиков, В.И. Химия и технология переработки каменноугольной смолы. М.: Металлургия.

2. Ковалев, Е.Т. (2001). Научные основы и технология переработки высококипящих фракций каменноугольной смолы с получением полициклических углеводородов. Харьков: Контраст.

3. Ковалева, Е. Л. (ред.). (2009). Справочник коксохимика. Т. 3. Улавливание и переработка химических продуктов коксования. Харьков: ИДИНЖЭК.

4. Глузман, Л.Д. \& Эдельман, И.И. (1968). Лабораторный контроль коксохимического производства. М.: Металлургия.

5. Эфрос, Л.С., Горелик, М.В. (1980). Химия и технология промежуточных продуктов. Л.: Химия.

6. Венкатараман, К. (1977). Химия синтетических красителей. (Т.5.). Л. : Химия.

7. Чекалин, М.А., Пасет В.Б. \& Иоффре Б. А. (1972). Технология органических красителей и промежуточных продуктов. Л.: Химия.

8. Попов, Є.В. \& Мороз, О.В. (2016). Синтез поліциклічних барвників із компонентів коксової смоли. Хімічна промисловість України, (3-4).

9. COLORINDEX 80. Band 2. (1980). Farbstoffe für Leder und Rauchwaren, Farbstoffe für andere Industriezweige sowie organische Pigmente. Интерхим. Галле.

\section{РАЗРАБОТКА ШАГАЮЩЕЙ СЕЯЛКИ ДЛЯ КРУГОВЫХ ЛЕСНЫХ ПИТОМНИКОВ}

\author{
Бырдина Светлана Сергеевна \\ магистрант \\ Братский государственный университет \\ РОССИЙСКАЯ ФЕДЕРАЦИЯ
}

По способу организации территории лесного питомника и характеру технологического процесса, кроме классических прямоугольных, выделяют круговые и подпологовые лесные питомники. Круговые лесные питомники имеют площадь в виде эллипса или круга, в центре которого и по краям сохраняется естественное насаждение. Такая организация территории 
позволяет выращивать посадочный материал в условиях более близких к лесной среде и избежать трудоемких работ по отенению посевов.

Подпологовые круговые питомники организуют для выращивания посадочного материала с улучшенной наследственностью, однако имеют не высокий уровень механизации технологических процессов ввиду расположения посевных строк по кругу или эллипсу [1].

Для решения поставленной проблемы и повышения уровня механизации посева семян в лесных круговых питомниках был проведен анализ существующих сеялок для круговых питомников (Авторское свидетельство СССР №1563612 «Универсальная роторная пропашная широкозахватная сеялка» [2] и Патент РФ на изобретение № 2119278 [3]) и разработана шагающая сеялка для круговых питомников и подана заявка на изобретение.

Согласно Авторскому свидетельству СССР №1563612 (рис. 1) универсальная роторная пропашная широкозахватная сеялка состоит из рамы с установленными на ней семенными бункерами, шарнирно соединенных с ними поводков-семяпроводов с семенными камерами, роторов, установленных на полой оси, разделенной на полости повышенного и пониженного давления воздуха.

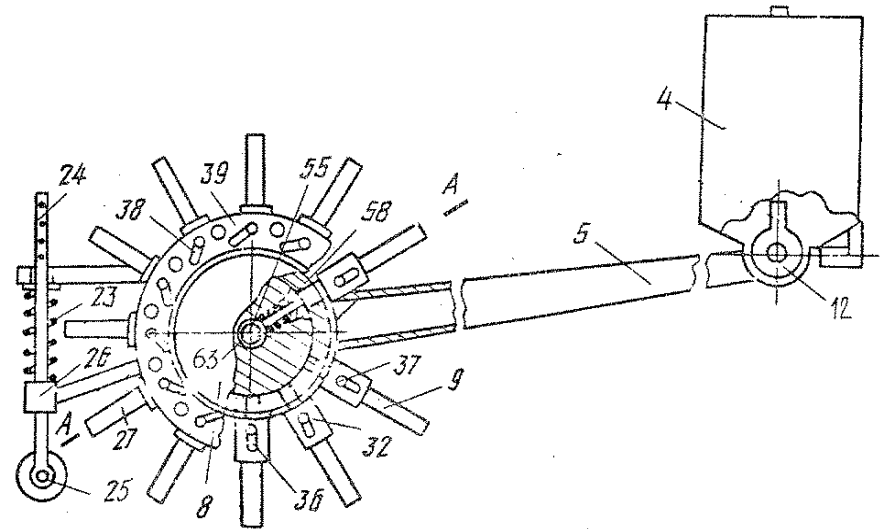

\section{Рис. 1. Универсальная роторная пропашная широкозахватная сеялка}

Роторы снабжены посадочными органами, установленными в цилиндрических втулках с возможностью радиального перемещения. Посадочные органы снабжены подвижными посадочными пальцами. При движении сеялки роторы, взаимодействуя с почвой, перекатываются по ней и посадочные органы заглубляются в почву на заданную глубину заделки семян. Представленная сеялка имеет сложную конструкцию и энергозатратна в эксплуатации.

Шагающая сеялка (Патент РФ №2119278 «Шагающая сеялка», рис. 2) используется для строчно-луночного посева хвойных пород на захламленных порубочными остатками свежих вырубках (лесосеках) без предварительной подготовки почвы во всех лесорастительных зонах.

Она проста в эксплуатации. Ее можно навешивать на все типы тракторов, чтобы она двигалась по следу трактора, что увеличивает ее проходимость. Шагающая сеялка содержит раму, шестеренчатый диск, высевающее 
устройство в виде барабана с семенной камерой, на цилиндрической поверхности которого равномерно в одной вертикальной плоскости закреплены посевные пальцы с радиальным углом между собой $60^{\circ}$. Каждый палец выполнен в виде двух установленных одна в другую труб. Внутренняя труба закреплена на барабане. Проставленная сеялка не предназначена для работы в организованных лесных питомниках.

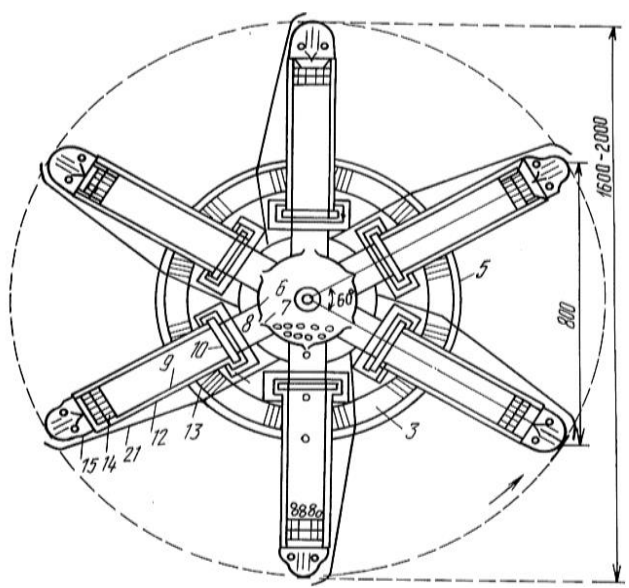

Рис. 2. Шагающая сеялка

Для посева семян в лесных механизированных круговых питомниках была разработана конструкция шагающей сеялки (рис. 3) и подана заявка на патент.

Шагающая сеялка (рис.3) имеет раму 1 с жестко закрепленными на ней стойками 2 в которых на полуосях 3 с возможностью свободного вращения установлены высевающие устройства 4.

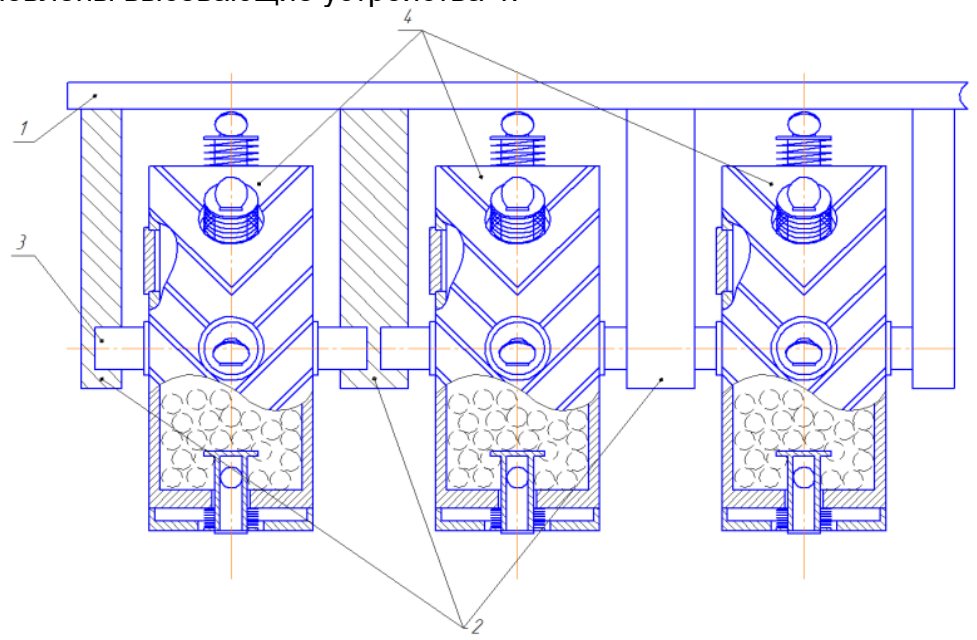

Рис. 3. Вид общий шагающей сеялки 
38 - Problèmes et perspectives d'introduction de la recherche scientifique innovante $\bullet$ Volume 3

Высевающее устройство 4 (рис. 4) выполнено в виде барабана 5 с семенной камерой, на цилиндрической поверхности которого равномерно в одной вертикальной плоскости через равное расстояние в отверстиях 6 установлены посевные пальцы 7, а на спицах 8 жестко закреплен обод 9 имеющий отверстия 10 под посевные пальцы 7 и оснащенный грунтозацепами 11. Высевающее устройство 4 в боковой части оснащено загрузочным отверстием 12 с крышкой 13.

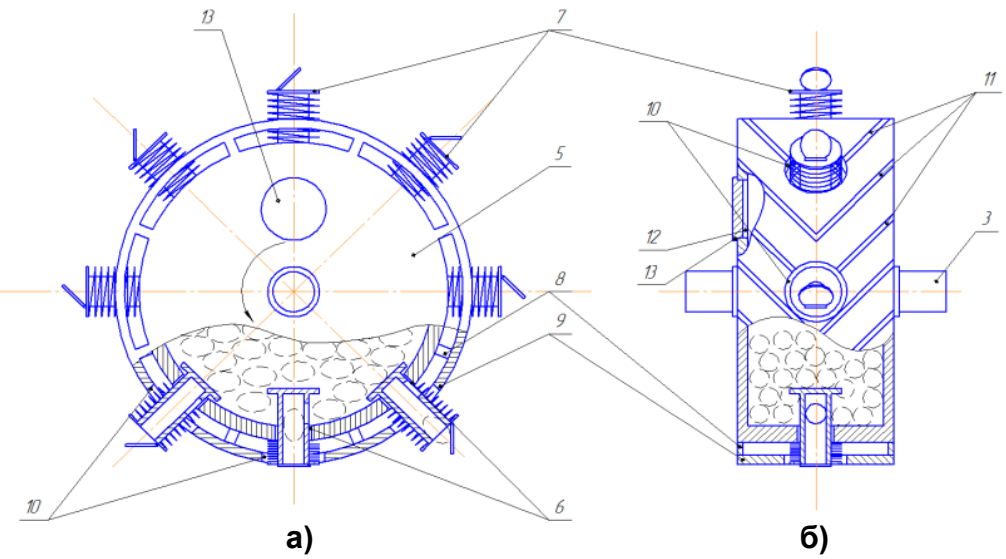

Рис. 4. Высевающее устройство: а) главный вид, б) вид сбоку

Каждый посевной палец 7 (рис. 5) выполнен в виде стакана с упором 14 и отверстием 15 в боковой части и оснащен упорной шайбой $16 \mathrm{c}$ подпружиненной крышкой 17. Посевной палец 7 установлен в отверстии 6 барабана 5 по средствам пружин 18.

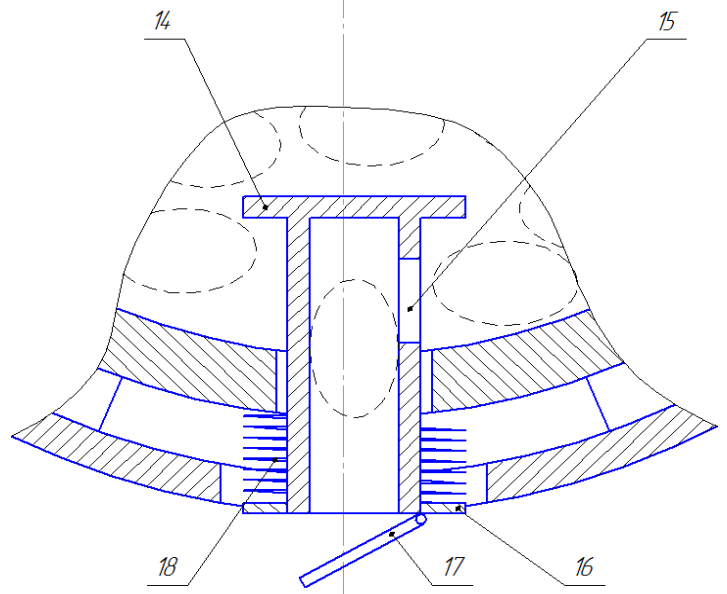

Рис. 5. Посевной палец 
Шагающая сеялка работает следующим образом.

Перед началом работы на раму трактора 1 (рис. 3) по средствам стоек 2 устанавливаю необходимое число высевающих устройств 4 равное количеству строк посева и загружают семена в семенные камеры высевающего устройства 4 через отверстия 12 (рис. 4). После загрузки семян отверстия 12 закрывают крышками 13. Далее шагающая сеялка устанавливается на посевную полосу и трактор начинает движение.

В процессе движения трактора высевающее устройство 4 испытывая сопротивление грунта начинает по средствам контакта почты С грунтозацепами 11 проворачивается на полуосях 3 . В процессе вращения высевающего устройства 4 посевной палец 7 встречаясь с поверхностью почвы начинает входить внутрь семенной камеры барабана 5, при этом подпружиненная крышка 17 (рис. 5) начинает закрывать выходное отверстие посевного пальца 7. При вертикальном положении посевного пальца 7 происходит полное закрытие крышки 17 и вхождение посевного пальца 7 в семенную камеру, что приводит к открытию отверстия 15 на боковой стороне посевного пальца 7. Под действием силы тяжести семя через отверстие 15 попадает во внутреннюю полость посевного пальца 7. При дальнейшем вращении высевающего устройства 4 посевной палец 7 под действием пружины 18 выходит из семенной камеры барабана 5 перекрывая отверстие 15 на боковой поверхности, а подпружиненная крышка 17 под действием пружины начинает открывать выходное отверстие через которое происходит выпадение находящегося во внутренней полости посевного пальца 7 семени в посевную строку. Наличие упора 14 препятствует полному выходу посевного пальца 7 из барабана 5.

Предложенная конструкция шагающей сеялки позволит производить посев семян равномерно через одинаковое расстояние независимо от радиуса поворота посевной ленты кругового лесного питомника.

\section{Список используемых источников:}

1. Бырдин, П.В. \& Невзоров, В.Н. Обеспечение рационального природопользования на основе круговых лесных питомников. Глобализация и эколого-экономическое развитие регионов: материалы науч.-практ. конфр. (с.112-116). 2015. Москва, Россия.

2. Чухматый, B.E. \& Чухматый, B.В. Универсальная роторная пропашная широкозахватная сеялка: автор. свид. 1563612 СССР. № заявки 4244794/30-15; заявл. 18.05.1987; опубл. 15.05.1990, (18).

3. Шадрин, А.П. Шагающая сеялка: пат. 2119278 Рос. Федерация. № заявки 97117869/13; заявл. 29.10.1997; опубл. 27.09.1998, (15). 


\section{РЕАЛІЗАЦІЯ СИСТЕМИ ЗD-ВІЗУАЛІЗАЦІЇ МЕДИЧНИХ ЗОБРАЖЕНЬ ФОРМАТУ DICOM}

Бондаренко Юлія Романівна

здобувач вищої освіти факультету фрізики, електроніки та комп'ютерних систем Дніпровський національний університет імені Олеся Гончара

Науковий керівник: Долгов Валерій Михайлович канд. фріз.-мат. наук, доцент кафедри комп'ютерних наук та інформаційних технологій Дніпровський національний університет імені Олеся Гончара

УКРÄ̈HA

Комп'ютерна (КТ) та магнітно-резонансна томографія (МРT) це сучасні методи обстеження, що дозволяють надати найбільш повну інформацію щодо стану здоров'я пацієнтів. Особливо важливим $є$ те, що у комп'ютерному виконанні дані повинні бути візуально зрозумілими для подальшої 3Dреконструкції. Зображення, отримані при проведенні КТ та МРТ, містять великий масив даних, що потребують швидкого аналізу для встановлення точного діагнозу, тому їх обробка потребує вдосконалення. Найбільш точним методом оцінювання стану органів та систем у реальному часі вважається високоякісна тривимірна реконструкція [1].

Тривимірна візуалізація поділяється на поверхневу (surface) і об'ємну (volume).

Метод поверхневої візуалізації полягає в тому, що спочатку структура виходить із середини геометричних примітивів за допомогою 3D-даних (таких як поверхня, площина тощо), а потім за допомогою технологій комп'ютерної графіки, такими як модель освітлення (reasonable illumination model), відображення текстури (texture mapping) і досягається повна візуалізація об'єкту (рис.1).

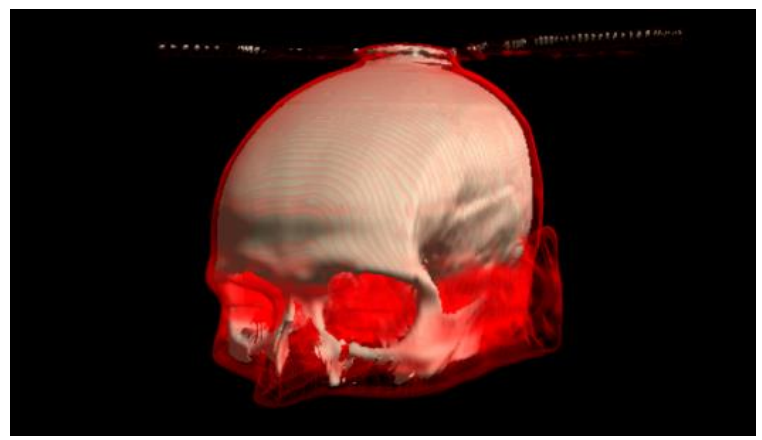

Рис. 1. Поверхнева візуалізація медичних зображень

Об'ємна візуалізація - це метод обробки даних об'єму в кожному елементі, а саме вокселі. Воксель - це основна одиниця об'ємного зображення, яка складається з двох частин сусідніх ділянок кожної з чотирьох точок куба (рис.2) [2]. 


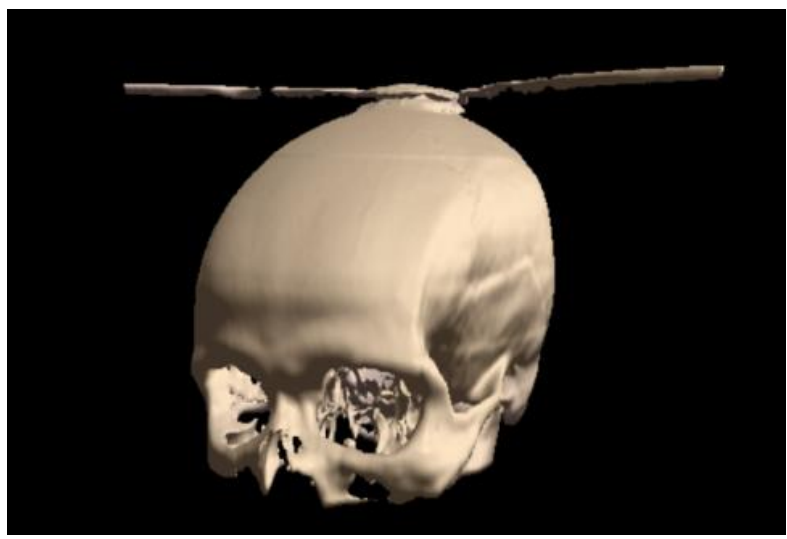

Рис. 2. Об'ємна візуалізація медичних зображень

3 аналізу зображень на рис. 1 та 2 можна зробити висновок, що об'ємна візуалізація більш якісна за поверхневу. Але зважаючи на інтерактивну продуктивність та ефективність, поверхнева візуалізація має переваги над об'ємною, тому що це стандартний інтерактивний алгоритм візуалізації графіки і при великому масиві даних, перетворення зображень виконується швидше [3].

Збільшення числа методів комплексної діагностики і вдосконалення медичної техніки продиктували розробку особливого формату даних, адаптованого під різні види апаратури і програмних засобів - DICOM (Digital Imagingand Communications in Medicine). Це стандарт даних, призначений для обробки і зберігання як окремих зображень, так і їх об'єднаних форм. Завдяки використанню DICOM виконується упорядкування файлів зображень $\mathrm{i}$, що важливо, їх зберігання 3 метою хронології результатів подальших діагностувань для визначення динаміки стану пацієнтів у ході лікування та/або після хірургічного втручання [4].

Висновки. Таким чином, проаналізовані методи тривимірної візуалізації дозволяють констатувати, що поверхнева візуалізація $є$ необхідною для встановлення більш точних діагнозів з метою призначення ефективного терапевтичного лікування, а більш деталізовану інформацію про стан пацієнтів з метою хірургічного планування, можна отримати тільки у разі розробки 3Dреконструкцій. Використання формату DICOM дозволить більш повно здійснити моніторинг стану пацієнтів у ході лікування та визначити рівень ефективності спланованих медичних заходів.

\section{Список використаних джерел:}

1. Lorensen, W. \& Cline, H. (1987). A High Resolution 3D Surface Construction Algorithm. Computer Graphics, (21).

2. Patra, A. \& Wang, M. (2003). Volumetric medical image compression and reconstruction for interactive visualization in surgical planning. 
3. Kajiya, J. T. \& Herzen, B. P. (1984). Ray tracing volume densities. In siggraph'84: Proceedings of the 11th annual conference on Computer graphics and interactive techniques (pp. 165-174). New York, USA.

4. Goryunova, V. V., Kukhtevich, I. I. \& Erin, A. N. (2017). Funktsii navigatora meditsinskikh DICOMizobrazheniy. Mezhdunarodnyy studencheskiy nauchnyy vestnik? (4), 885-889. Вилучено 3 https://www.eduherald.ru/ru/article/view?id=17579

\section{РОБОТОТЕХНІКА В ЕРГОТЕРАПIÏ}

Мироненко Оксана Василівна

канд. фріз.-мат. наук, старший викладач кафедри медичної фізики та інформаційних технологій №2 Донецький національний медичний університет УКРАÏHA

Протягом останніх років і по нинішній час в Україні відбуваються військові дії, які кардинальним чином змінили життя певних категорій населення: військовослужбовців, добровольців, волонтерів, мирних жителів, що залишилися в зоні конфрлікту та внутрішньо переміщених осіб. Після повернення до мирного життя стан цих людей потребує як фрізичної, так $\mathrm{i}$ психолого-емоційної та соціальної реабілітації. Виходячи з цього, актуальною $€$ фахова підготовка і перепідготовка спеціалістів, здатних виконувати широкий спектр робіт в галузі реабілітації постраждалих внаслідок військового конфрлікту на Сході України [1].

На вимогу часу в нашій країні з'явилася нова медична спеціальність за реабілітаційним напрямком - ерготерапія, яка нещодавно була внесена до Класифікатора професій. Відповідно попереднім міністром Освіти і науки України Лілією Гриневич наказом № 1419 від 19.12.18p. затверджено стандарт вищої освіти за спеціальністю 227 «Фізична реабілітація, ерготерапія» [2], що дозволяє в медичних вишах України набувати фаху лікаря-ерготерапевта.

Ерготерапія (осcupational therapy- англ., походить від латинської «ergon» діяльність, і грецької «therapia» - лікування) - це медико-соціальна спеціальність, заснована на принципах доказової медицини (evidence-based medicine), яка спрямована на покращення фрізичного та психічного здоров'я пацієнта за допомогою різних видів цілеспрямованої діяльності з метою поліпшення якості життя особистості [3]. Ерготерапія пов'язує соціальну психологію та фрізичну терапію з такими новітніми галузями науки, як біомеханіка, робототехніка та інші. У сучасну медичну галузь вже впроваджено велику кількість роботизованих пристроїв та систем, які застосовуються при обслуговуванні пацієнтів в ході їх реабілітації.

Одним із засобів ерготерапії осіб з обмеженими можливостями, або травмованих протягом життя (зокрема військовими діями в Україні) можна розглядати заняття робототехнікою з метою їхньої самореалізації. У зв'язку 3 цим актуальною $є$ розробка різноманітних курсів з робототехніки в ерготерапії для покращення дрібної моторики і координації рухів та поліпшення психо- 
емоційного стану пацієнтів, що дозволить їм призвичаїтися до нових побутових умов, урізноманітнити своє дозвілля, та навіть поновити трудову діяльність. Адже робототехніка, як засіб ерготерапії дає особистості ряд можливостей:

- набути знань і навичок програмування та роботобудування, що може стати основою актуальної і перспективної професії та надати впевненості у своєму майбутньому;

- створити роботизовані пристрої, що можуть допомогти у побуті, поліпшити фрізичні можливості людини з інвалідністю та надати йй незалежності від оточуючих;

- стати захоплюючим сучасним хобі, що сприяє появі широкого кола спілкування, тобто розвитку комунікабельності і пристосуванню до сучасного соціуму, та інші.

Для робототехніків-початківців зручною для набуття первинних знань та навичок $є$ електронна платформа-мікроконтролер (электронный конструктор) Arduino (або його аналоги), побудована на простій друкованій платі з сучасним середовищем для написання програмного забезпечення 3 можливістю розширення і відкритим вихідним текстом. Програмне забезпечення Arduino випускається як інструмент, який може бути доповнений досвідченими користувачами. Основою бібліотечної (не потребує написання функцій користувачем) мови програмування Arduino $€$ C++. Створені на базі Arduino електронні роботизовані пристрої сприймають навколишнє середовище завдяки прийому сигналів від різних цифрових і аналогових датчиків, які можуть бути підключені до нього, і управляють різними виконавчими пристроями, що впливають на навколишнє середовище, керуючи освітленням, двигунами та іншими приводами [4]. Такі пристрої можуть працювати самостійно або взаємодіяти з програмним забезпеченням комп'ютера.

Висновки. У процесі даного дослідження показано важливість розробки сучасних підходів до робототехніки, як складової ерготерапії, для фрізичної та соціально-психологічної реабілітації особистості. Сучасна ерготерапія, 3 набуттям навичок програмування робототехнічних пристроїв та керування ними, сприятиме інтелектуальному розвитку, зміцненню м'язового тонусу, розвитку координаційних здібностей, реакцій рівноваги, загальної та дрібної моторики, моторного планування, покращить сприйняття сенсорної інформації людиною з обмеженими можливостями і психологічними травмами та дозволить їй інтегруватися у сучасне життя в світі інформаційних технологій.

\section{Список використаних джерел:}

1. Малахов, В.О., Кошелєва, В. О. \& Родін, В.О. (2016). Фізична та реабілітаційна медицина в Україні: проблеми та перспективи. Проблеми безперервної медичної освіти та науки, (1), 6-12.

2. Про затвердження стандарту вищої освіти за спеціальністю 227 «Фізична реабілітація, ерготерапія» (Наказ МОН України). №1419. (2018). Вилучено 3 https://mon.gov.ua/storage/app/media/vishcha-osvita/zatverdzeni\%20standarty/12/ 21/227fizichna-terapiya-ergoterapiya-bakalavr.pdf.

3. Обладнання для навчальних та реабілітаційних установ. (2019). vemakids.com.ua. Вилучено з https://vemakids.com.ua/ua/ergoterapiya.

4. Офіційний сайт Arduino. (2019). Вилучено з http://arduino.cc/. 


\section{РОЗРОБКА ЛІНІЙНОГО БЛОКУ ЖИВЛЕННЯ}

НАУКОВО-ДОСЛІДНА ГРУПА:

Байдацький Ігор

здобувач вищої освіти радіотехнічного відділення

Вінницький технічний коледж

Париський Андрій

здобувач вищої освіти радіотехнічного відділення

Вінницький технічний коледж

Фурман Ігор

здобувач вищої освіти радіотехнічного відділення

Вінницький технічний коледж

Науковий керівник: Тромсюк Володимир Дмитрович кандидат технічних наук, викладач спеціальних дисциплін

Вінницький технічний коледж

УКРӒ̈HA

В зв'язку із проведенням тижня радіотехніки у Вінницькому технічному коледжі був проведений конкурсу на краще джерело живлення. За результатами конкурсу було обрано три найкращі роботи. Завдання полягало у розробці блоку живлення з такими параметрами:

- вихідна напруга повинна регулюватися в межах від 5 до 24 В;

- струм навантаження повинен бути не менше 1 A;

- рівень пульсацій на виході не більше 50 мВ;

- має бути наявний захист від короткого замикання;

- повинні бути індикатори струму і напруги на виході блоку живлення.

Збираючи лабораторний блок живлення своїми руками, багато хто стикається з проблемою вибору схеми. Імпульсні блоки живлення при налагодженні саморобних передавачів або приймачів можуть давати небажані перешкоди в ефір, а лінійні блоки живлення часто не в силах розвивати велику потужність [1-4]. Майже універсальним блоком може стати простий лінійний блок живлення 0-30В і струмом 0 - ЗА, який буде працювати в режимі стабілізації струму і напруги.

Перша конкурсна робота (рис. 1). Стабілізатор напруги для лабораторного блоку живлення (рис. 1) має регулювання в межах: 0-24 В вихідна напруга і в межах 0-2,5 А максимальний вихідний струм.

Контролюючим елементом від короткого замикання виступає реле, воно підключено паралельно навантаженню. При подачі напруги реле буде розімкнуте, про це інформує червоний світлодіод. На вхід пристрою через обмотку реле протікає струм, реле підключає навантаження і загориться синій світлодіод. Під час короткого замикання напруга на реле різко впаде, і воно відключить навантаження, при цьому загориться червоний світлодіод, який проінформує про коротке замикання в схемі пристрою. 


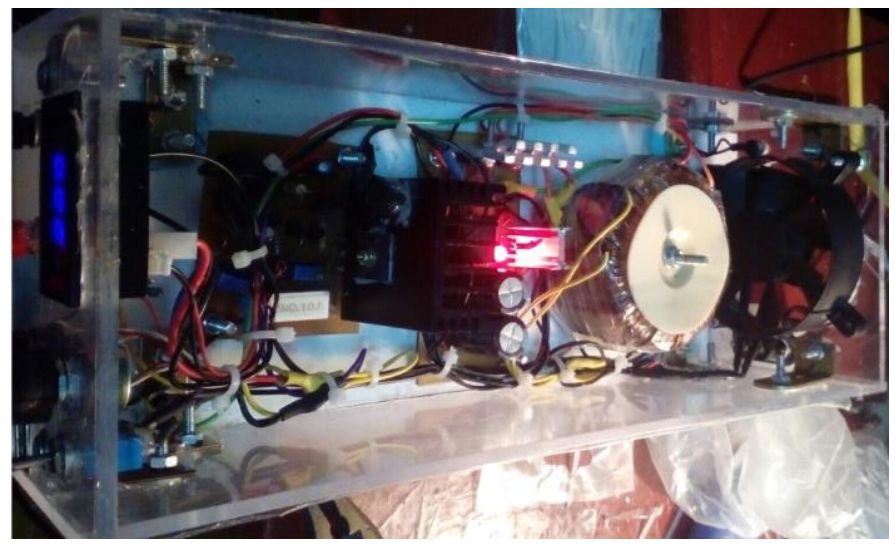

Рис. 1. Лінійний блок живлення (перша конкурсна робота)

Друга конкурсна робота (рис. 2). 3 трансформатора подається понижена змінна напруга, яка протікає через діодний міст та випрямляється. Випрямлена напруга подається на конденсатор С1, який згладжує пульсації, з нього напруга протікає на вхід стабілізатора LM317 та колектор потужного транзистора MJE13009, який призначений для збільшення потужності схеми, яка завдяки йому зможе видавати до 10A [3, 4]. Присутні два шунтуючих резистори R1 i R2 опором 200 Ом, завдяки яким мікросхема стабілізатора визначає напругу на виході і порівнює 3 напругою на вході. Регулюванням опору змінним резистором P1 керує подачею напруги на стабілізатор, тим самим регулюється напруга на виході схеми [1]. Конденсатор C2 згладжувальний. Резистор R3 на 10К розряджає конденсатор C1, C2 після відключення блоку живлення.

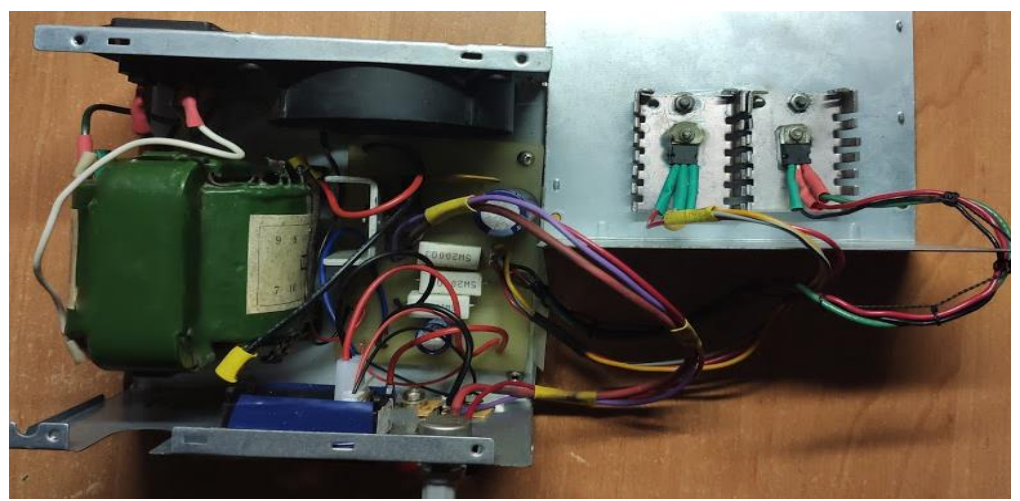

Рис. 2. Лінійний блок живлення (друга конкурсна робота)

Третя конкурсна робота (рис. 3). В цьому джерелі живлення [5]: напруга на виході плавно регулюється в діапазоні 3-25B; струм досягає 2A; 
використовується мікросхема LM723 з захистом від короткого замикання; діодний міст перетворює зміну напругу в постійну; два конденсатора на 10000 мкФх35В згладжують пульсації.
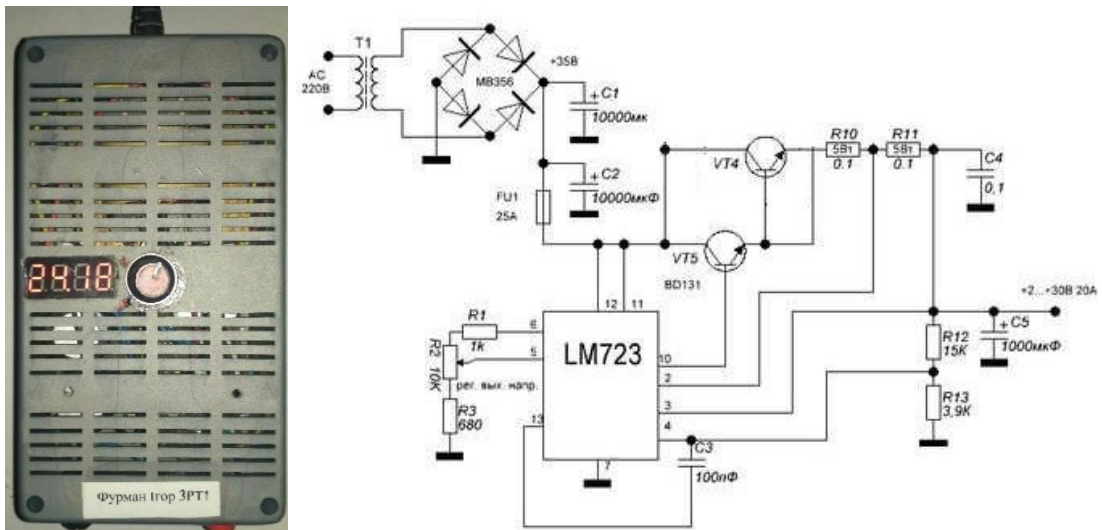

Рис. 3. Лінійний блок живлення (третя конкурсна робота)

Висновки: проведений конкурс сприяв вдосконаленню практичних навиків студентів при розробці та виготовленні власних малопотужних лінійних блоків живлення. Призери конкурсу справилися із виконанням технічного завдання та виготовили блоки живлення у відповідності до технічного завдання із деяким запасом вихідних параметрів. В подальшому, виготовлені блоки живлення, знадобляться для тестування інших радіотехнічних виробів студентами, для перевірки їх працездатності та відповідності технічним завданням.

\section{Список використаних джерел:}

1. Ситников, А. В. (2018). Электротехнические основы источников питания. Москва: КУРС: ИНФРА-М.

2. Тромсюк, В. \& Климчук, Б. (2017). Лабораторний блок живлення. Інженерія радіоелектронних систем і пристроїв: студентська науково-практична конфреренція (с. 39-40). 5 грудня, 2017, Харків, Україна: ХНУРЕ.

3. Тромсюк, В. \& Соколовський, О. (2018). Лабораторний блок живлення на дискретних елементах. Тенденції та перспективи розвитку науки і освіти в умовах глобалізації: матеріали XXXVII Міжнародної науково-практичної інтернет-конфреренції (с. 395-398). 27 червня, 2018, Переяслав-Хмельницький, Україна: ДВНЗ

4. Тромсюк, В. \& Метелиця, А. (2019). Вплив параметрів конденсаторів на запуск AC-DC перетворювачів. Теоретичні та прикладні аспекти радіотехніки, приладобудування $i$ комп'ютерних технологій: IV Міжнародна науково-технічній конфреренція (с. 125-127). 21 червня, 2019, Тернопіль, Україна: ФОП Паляниця В. А.

5. Семьян, А. П. (2005). 500 схем для радиолюбителей. Источники питания. СПБ.: Наука и техника. 


\section{ТЕХНИЧЕСКОЕ РЕГУЛИРОВАНИЕ В РАМКАХ ЕВРАЗИЙСКОГО ЭКОНОМИЧЕСКОГО СОЮЗА}

Мусатаева Дина Толеуовна

магистрант транспортно-энергетического факультета

Евразийский национальный университет

Тайманова Гульнара Кабжановна

канд. техн. наук, доцент

Евразийский национальный университет

РЕСПУБЛИКА КАЗАХСТАН

Впервые идею формирования Евразийского союза выдвинул Президент Республики Казахстан Нурсултан Назарбаев 29 марта 1994 года.

В 1995 году с подписания Соглашения о Таможенном союзе Беларуси, Казахстана и России началось сближение евразийских государств. На протяжении последующих 20 лет Таможенный союз последовательно и направленно двигались к созданию Единого экономического пространства и Евразийского экономического союза.

С 1 января 2015 года стартовал современный этап интеграции, с началом функционирования Евразийского экономического союза, Договор о создании которого был подписан президентами Беларуси, Казахстана и России в Астане 29 мая 2014 года. В 2015 году к Договору о Евразийском экономическом союзе (далее - ЕАЭС) присоединились Республика Армения и Кыргызская Республика, которые еще с 2012 года вели подготовительную работу.

Отличительной чертой евразийского интеграционного проекта от прежних аналогичных инициатив на пространстве СНГ является наличие постоянно действующего регулирующего органа - Евразийской экономической комиссии.

Комиссия управляется Советом и Коллегией. В Совет входит по одному вице-премьеру от каждой стороны, решения принимаются консенсусом. В Коллегии каждое государство представлено двумя членами Коллегии, решения принимаются квалифицированным большинством или консенсусом. Решения Комиссии имеют прямое действие на территории государств членов Союза. Дополнительного одобрения на национальном уровне не требуется.

В Едином экономическом пространстве Техническое регулирование является базовым элементом интеграции. Установление единых обязательных требований к продукции в технических регламентах ЕАЭС первостепенная задача, реализуя которую обеспечивается одна из основных условий свободного движения товаров. Переход на единые требования сопровождается существенной гармонизацией всех задач и функций, связанных с применением технических регламентов в странах-участницах. Это и переход на международно-признанную практику в таких направлениях, как стандартизация, аккредитация, обеспечение единства измерений, и унифрикация принципов государственного контроля (надзора) и ответственности за выпуск продукции, не соответствующей обязательным 
48 - Problèmes et perspectives d'introduction de la recherche scientifique innovante $\bullet$ Volume 3

требованиям и т.д. Данный подход применяем в Евросоюзе и других интеграционных объединениях [1].

Свобода перемещения товаров (продукции) обеспечивается путем принятия единых технических регламентов Евразийского экономического союза [2].

На сегодняшний день приняты 47 TP ЕАЭС, из них 42 вступили в силу и покрывают большую часть взаимопоставляемой продукции (60-65\%) .

При этом, в Республике Казахстан сохранили действие 22 национальных технических регламентов (которые подлежат отмене со дня вступления в силу соответствующего ТР ЕАЭС в отношении объекта регулирования).

Разработка единых технических регламентов и межгосударственных стандартов, гармонизированных с международными требованиями, учитывающих лучшие мировые практики и тенденции развития различных отраслей, позволит облегчить доступ товаров из ЕАЭС на рынки третьих стран, повысит их конкурентоспособность среди товаров импортного производства.

\section{Список используемых источников:}

1. Корешков, В. (2012). Далекое-близкое: просто о техническом регулировании. Библиотека Евразийской интеграции.

2. Договор о Евразийском экономическом союзе. (2014). Изъято из http://www.eurasiancommission.org/ 


\section{SECTION IV. SCIENCES PHYSIQUES ET MATHÉMATIQUES}

\section{ПОХІДНА ДРУГОГО ПОРЯДКУ ЯК ІНСТРУМЕНТ РОЗВ ЯЗАННЯ ТРАНСЦЕНДЕНТНИХ РІВНЯНЬ, ЩО МІСТЯТЬ ПАРАMЕТР}

\section{Новікова Наталія Володимирівна}

викладач-методист, голова ЦК комп'ютерно-інтегрованих технологій Машинобудівний коледж Донбаської державної машинобудівної академії

Карнаух Ірина Василівна

викладач вищої категорії ЦК комп'ютерно-інтегрованих технологій Машинобудівний коледж Донбаської державної машинобудівної академії

УКРАÏHA

Вивчення багатьох геометричних, фрізичних і економічних закономірностей нерідко приводить к застосуванню математичних моделей, які зводяться до трансцендентних рівнянь. Наприклад, відоме рівняння Кеплера, яке описує рух тіла в задачі двох тіл $є$ трансцендентним. Такі рівняння відіграють велику роль у фрормуванні логічного мислення та математичної культури студентів, але їх розв'язок дуже часто викликає деякі труднощі. Це пов'язано з тим, що трансцендентні рівняння утворюють дуже багато класів рівнянь, кожен з яких складається 3 різного набору функцій. Тому дуже часто ці рівняння розв'язуються геометричними методами, за допомогою похідних та 3 застосуванням чисельних методів.

Існує багато методів [1] щодо знаходження кореня такого рівняння з певною точністю, застосування яких ускладнюється, якщо у рівнянні присутній параметр. Також труднощі можуть виникнути, коли при певному значенні параметра існує лише один корінь. Тому метою дослідження $є$ описати метод застосування другої похідної для більш досконалого дослідження трансцендентних рівнянь з параметром..

Нехай треба знайти кількість коренів рівняння $\mathrm{x}^{2}-\mathrm{x}-\ln \mathrm{x}+\mathrm{m}=0$ при будьяких значення $\mathrm{m}$ та знайти $\mathrm{m}$, для якого корінь тільки один. Спочатку розгляне випадок, коли $\mathrm{m}=0$. Маємо $\mathrm{x}^{2}-\mathrm{x}=\ln \mathrm{x}$. Підстановкою отримаємо точне значення кореня $\mathrm{x}=1$. Доведемо , що воно тільки одно. Введемо функції $f_{1}(\mathrm{x})=\mathrm{x}^{2}-\mathrm{x}$ та $f_{2}(\mathrm{x})=\ln \mathrm{x}$. Для $f_{1}(\mathrm{x})=\mathrm{x}^{2}-\mathrm{x}$ друга похідна $f_{1}^{\prime \prime}(\mathrm{x})=2>0$, тобто фрункція угнута і точки її графріка лежать вище дотичної $\mathrm{y}=\mathrm{x}+1$, окрім самої точки дотику. Для $f_{2}(\mathrm{x})=\ln \mathrm{x}$ маємо $f_{2}^{\prime \prime}(\mathrm{x})=-\frac{1}{\mathrm{x}^{2}}<0$, тобто функція опукла [2] і точки її графріка нижче дотичної $\mathrm{y}=\mathrm{x}+1$, окрім самої точки дотику. Тобто при $\mathrm{m}=0$ корінь $\mathrm{x}=1$ - тільки один.

Тепер розглянемо випадки коли $\mathrm{m}>0$ та $\mathrm{m}<0$. Графріком функції $f_{1}(\mathrm{x})=\mathrm{x}^{2}-$ x $€$ парабола з вітками вгору, а графріком функції $f_{2}(\mathrm{x})=\ln \mathrm{x} \in$ зростаюча крива. Якщо при $\mathrm{m}=0$ ці графіки мають тільки одну спільну точку, то при $\mathrm{m}>0$ ми маємо фуннції $f_{1}(\mathrm{x})=\mathrm{x}^{2}-\mathrm{x}+m$ та $f_{2}(\mathrm{x})=\ln \mathrm{x}$,графіки яких не 
50 • Problèmes et perspectives d'introduction de la recherche scientifique innovante $\bullet$ Volume 3

перетинаються, так як параболу підняли по осі ОУ на m одиниць. Тобто, якщо $\mathrm{m}>0$, рівняння коренів не має.

Коли $\mathrm{m}<0$ ми маємо функції $f_{1}(\mathrm{x})=\mathrm{x}^{2}-\mathrm{x}-|m|$ та $f_{2}(\mathrm{x})=\ln \mathrm{x}$, які перетинаються обов'язково в двох точках, так як параболу опустили по осі ОУ на $\mathrm{m}$ одиниць. Тобто, якщо $\mathrm{m}<0$, рівняння завжди має два кореня.

Таким чином, використовуючи другу похідну та означення опуклості та угнутості можна досліджувати певний тип трансцендентних рівнянь 3 параметром. Якби мова йшла про знаходження коренів при $\mathrm{m}<0$, при достатньо малих за абсолютною величиною значеннях $\mathrm{m}$, то можна було б скористатися розкладенням функції $f_{2}(\mathrm{x})=\ln \mathrm{x}$ у ряд Тейлора [3] коло точки $\mathrm{x}$ $=1$.

\section{Список використаних джерел:}

1. Амелькин, В. В. \& Рабцевич, В. Л. (2004). Задачи с параметрами: Справочное пособие по математике. Мн.: Aсар.

2. Пак В. В. \& Носенко Ю. Л. (1996). Вища математика. Київ: Либідь. ISBN 5- 325-00712-2.

3. Овчинников, П. П. (2004). Вища математика: збірник задач. Київ: Техніка.

4. Демидович, Б. П. \& Моденов, В. П. (2008). Диференційні рівняння (3-є вид.). СПб.: Видавництвоство «Лань». 


\title{
SECTION V. SCIENCES CHIMIQUES
}

\section{ПЕДАГОГІЧНА ДІЯЛЬНІСТЬ ВЧИТЕЛЯ 3 ФОРМУВАННЯ КОМУНІКАТИВНИХ КОМПЕТЕНТНОСТЕЙ УЧНІВ ЗАСОБАМИ XIMІЧНОЇ ОСВІТИ: КОЛЕКТИВНИЙ СПОСІБ НАВЧАННЯ}

\author{
Базілевська Лідія Пантелеймонівна \\ вчитель хімії, категорія вища \\ Черкаська загальноосвітня школа I-III ступенів № 25 \\ Черкаської міської ради Черкаської області
}

УКРАÏHA

Сучасне суспільство потребує успішних випускників з розвиненими моральними та вольовими якостями, які вміють творчо мислити, успішно спілкуватись, прогнозувати надзвичайні ситуації та володіють високим ступенем мобільності. Тож, успішний випускник - це один з головних напрямків роботи сучасного вчителя, зокрема вчителя хімії.

Відповідно до цього, першочерговими завданнями, які вирішуються сучасною хімічною освітою в школі, вважаються: освоєння системи знань про фундаментальні закони, теорії та факти хімічної науки, її внеску в загальнолюдську культуру для розуміння наукової картини світу; розвиток пізнавальних інтересів, інтелектуальних і творчих здібностей учнів у процесі вивчення хімії; виховання в них переконаності в тому, що остання є потужним інструментом для перетворення природи, а її безпечне застосування можливо тільки в суспільстві зі стійкою моральною свідомістю.

Мета наукової розвідки: визначити значення колективного способу навчання учнів на уроках хімії в розвитку їх комунікативних компетентностей.

Об'єкт вивчення: педагогічна діяльність вчителя 3 формування комунікативних компетентностей учнів засобами хімічної освіти.

Предмет дослідження: колективний спосіб навчання хімії.

Історіографічна база. Окреслена проблема неодноразово привертала до себе увагу вітчизняних науковців. Потрібно відзначити роботи Л. Гейко [1], Н. Лукашової [2], О. Фединяк, С. Родзень [3] та інших авторів. Втім, не всі аспекти даної проблеми знайшли достатнє відображення в наукових студіях, тому необхідність їі подальшого поглибленого вивчення залишається актуальною й надалі.

В основі розвитку комунікативної культури учнів на уроках хімії знаходяться концептуальні засади педагогічних технологій співпраці, спілкування та колективно-пізнавальної діяльності [2]. Зокрема, формування комунікативних компетентностей учнів на уроках хімії стає можливим у процесі педагогічної діяльності, що включає, перш за все, колективні способи навчання.

Реалізація системи педагогічної діяльності з розвитку комунікативних компетентностей учнів на уроках хімії має бути забезпечена сучасним обладнанням кабінету хімії, який оснащений не лише необхідними реактивами 
та устаткуванням, але й сучасною комп'ютерною технікою та базою цифрових освітніх ресурсів [1].

На уроках хімії досить важливо грамотно організувати пізнавальну діяльність учнів для того, щоб не тільки урізноманітнити заняття та викликати інтерес до предмета, але й сформувати в них стійку мотивацію до навчання [2]. Це все стає можливим завдяки створенню належних умов для активної позиції учнів у процесі навчання, оскільки успішний учень - це дитина, яка володіє розвиненими компетентностями, найважливішою 3 яких $\epsilon$ комунікативна [3].

Система педагогічної діяльності 3 розвитку комунікативних компетентностей учнів на уроках хімії заснована на концептуальних принципах таких теорій і технологій як: співробітництво, теорія спілкування, психологопедагогічна теорія особистості, гуманістична модернізація традиційних методичних механізмів, колективні способи навчання, колективна навчальнопізнавальна діяльність, метод проектів, педагогічне проектування тощо [1].

Потрібно наголосити, що актуальність розвитку комунікативних компетентностей учнів засобами навчального предмета «Хімія», у процесі створення системи педагогічних знань з відповідного предмета, включає, насамперед, колективний спосіб навчання учнів [3].

Системне застосування репрезентованого способу на уроках хімії дає можливість учням створити стрижневий образ теми, допомагає засвоєнню та запам'ятовуванню матеріалу. Інакше кажучи, відповідний спосіб навчання сприяє встановленню просторових взаємин предметів та явищ, розвиває логічну послідовність мислення, уяву й спостережливість, тобто підвищує інтерес учнів до досліджуваного матеріалу, активізує їх пізнавальну діяльність. До того ж, колективний спосіб навчання на уроках хімії має загально класну, групову та парну форми, а також виконує не лише комунікативну функцію, але й соціалізаційну та корекційну [2].

Ускладнення форм роботи, наприклад, запропонованих завдань, має відбуватись не тільки зі зміною віку учнів, доцільно застосовувати цей спосіб під час різнорівневих етапів вивчення нового матеріалу. Так, на першому етапі вчитель хімії пояснює новий матеріал всьому класу, а потім учні в малих групах або парах відпрацьовують його на уроці. На другому, - відбувається укрупнення вчителем хімії навчального матеріалу й подання його учням блоками. У цьому випадку, вчитель для відпрацювання матеріалу застосовує наступні методики: хімічний диктант, взаємообмін завданнями, різні прийоми парної роботи, взаємоперевірку індивідуальних завдань тощо. На третьому, вивчення нового матеріалу на уроці хімії передбачає розподілення програмного матеріалу з хімії протягом всього навчального року. Якраз тоді й представлені всі основні ознаки колективної роботи, а саме: кооперація та взаємодія всіх з усіма. Важливою ознакою цього етапу є організація навчальної роботи через «занурення у предмет». Останнє, перш за все, стосується таких тем, як «Хімічний практикум», «Будова та класифікація органічних сполук», «Механізми реакцій в органічній хімії» та інші. На четвертому, - вивчення нового матеріалу відбувається в ході роботи хімічного гуртка. Для нього характерна наявність різновікової групи учнів, які цікавляться хімією та перебудова навчального процесу [1; 3]. 
Таким чином, досліджуючи проблему колективного способу навчання учнів засобами хімічної освіти 3 метою формування в них комунікативних компетенцій, авторка наукової розвідки дійшла висновків, що реалізація системи педагогічної діяльності на заняттях 3 хімії у цьому напрямку дозволяють суттєво підвищити якість навчання та рейтинг окремих учнів класу.

\section{Список використаних джерел:}

1. Гейко, Л. (2014). Шляхи підвищення якості хімічної освіти: вдосконалення сучасного уроку: навчально-методичний посібник за матеріалами інтернет-семінару. Черкаси: ЧОІПОПП. $142 \mathrm{c}$.

2. Лукашова, Н. (2010). Становлення і розвиток методики навчання хімії в загальноосвітніх школах України. Ніжин: Видавництво НДУ ім. М. Гоголя, 315 с.

3. Фединяк, О. \& Родзень, С. (2019). Компетентнісний підхід у сучасній шкільній хімічній освіті: тенденції й проблеми розвитку: збірник наукових праць і всеукраїнської науково-практичної конференції. Івано-Франківьк: Супрун В. П. 


\section{SECTION VI. SCIENCES BIOLOGIQUES}

DOI 10.36074/29.11.2019.v3.04

\section{БІОЛОГІЯ ТА ЕКОНОМІКА: ДИЛЕМА В'ЯЗНЯ ТА БІОЛОГІЧНІ ПРИЧИНИ ІРРАЦІОНАЛЬНОЇ ПОВЕДІНКИ}

Тарасович Владислав Сергійович

здобувач вищої освіти біологічного факультету Донецький національний університет імені Василя Стуса

Науковий керівник: Боярська Зорина Олександрівна канд. біол. наук, доцент кафедри біофрізики і фрізіології Донецький національний університет імені Василя Стуса

УКРӒ̈HA

Сучасні соціальні науки останнім часом часто використовують науковий апарат, який змогла напрацювати біологічна наука. Біологія може пояснити нам багато особливостей людської поведінки. Прикладами таких пояснень можуть бути допущення і опити, які, наприклад, приходять до висновків, що одним з важливих компонентів у формуванні соціальної поведінки є речовина серотонін, що знаходиться в людському організмі [1].

Метою роботи є дослідження питань з поведінкової економіки і природи ірраціональної поведінки. Поведінкова економіка - це доволі нова галузь людського знання, яка намагається зрозуміти поведінку економічних агентів базуючись на соціології, психології та біології [2]. Мабуть, найважливішим компонентом поведінкової економіки, яка не так давно стала частиною економічного мейнстріму, є напрацювання математиків в теорії ігор.

Одною 3 фундаментальних проблем теорії ігор $€$ те, що називають «дилемою в'язня». Згідно з нею раціональні гравці частіше не будуть співпрацювати один з одним, навіть якщо це в їх інтересах. Передбачається, що гравець максимізує свій власний виграш, не піклуючись про вигоду інших. Якщо казати мовою математиків, то частіше за все учасники гри прагнуть до того, що називають рівновагою Неша [3]. Однак і крім того, що ми називаємо раціональною поведінкою люди досить часто діють нераціонально. Наприклад, відмовляються відповідати у грі в класичній дилемі в'язня або, кажучи мовою соціальних наук, люди ризикують, чи довіряються іншій людині, хоча раціонально було б довірятися тільки собі.

І для економіки, як і для самої теорії, ігор відкритим залишається питання про детермінанти цієї ірраціональної поведінки. Чому деякі люди діють не так, як діє більшість, спираючись на свій розум?

Ми маємо деякі припущення відносно цього запитання. Вважається, що в організмі людини окситоцин має важливе значення в формуванні довірчої поведінки, важливе значення в тому, як часто людині буде властиво довірятися іншим людям [4]. Ми також маємо припущення відносно того, що люди, які перебувають у відносинах, мають більш високий рівень окситоцину 
- частіше довіряються людям (взагалі всім людям). Виходячи з цього ми б могли допускати, що люди, які перебувають у відносинах мають більший рівень окситоцину - частіше діють іраціонально. Безперечно, питання потребує детального дослідження та обговорення.

\section{Список використаних джерел:}

1. Палмер, Дж. и Л. (2006). Секреты поведения Homo Sapiens. Эволюционная психология (170-179). Прайм-тайм: Еврознак.

2. Бернстайн, П. (2009). Фундаментальные идеи финансового мира. Москва: «Альпина Паблишер». ISBN 978-5-9614-0972-7.

3. Петросян, Л. А. \& Зенкевич, Н. А. \& Шевкопляс Е. В. (2012) Теория игр (190-194). СПб: БХВПетербург. ISBN 978-5-9775-0484-3

4. Meyer, D. (2007). Selective Serotonin Reuptake Inhibitors and Their Effects on Relationship Satisfaction. The Family Journal: journal. (Vol. 15, no. 4.), 392-397. DOI:10.1177/1066480707305470.

\section{ВИДОВИЙ СКЛАД МАКРОМІЦЕТІВ РЕКРЕАЦІЙНИХ ЗОН М. СЕЛИДОВЕ}

\section{НАУКОВО-ДОСЛІДНА ГРУПА:}

Приседський Юрій Георгійович

д-р. біол. наук, професор кафедри ботаніки та екології Донецький національний університет імені Василя Стуса

Решетник Катерина Сергіївна старший викладач кафедри ботаніки та екології Донецький національний університет імені Василя Стуса

Пляшечник Вікторія Вікторівна здобувачка вищої освіти фракультету хімії, біології та біотехнологій Донецький національний університет імені Василя Стуса

УКРӒ̈HA

Гриби є невід'ємним компонентом різних екосистем і в природі відіграють важливу роль у кругообігу речовин. Володіючи багатим ферментним апаратом, вони активно розкладають органічні речовини переважно рослинного походження (деревину, опад і підстилку), сприяючи утворенню родючого шару грунту. Велике значення в житті багатьох деревних i трав'янистих рослин мають мікоризні гриби. Вони покращують мінеральне живлення рослин [1].

Гриби відіграють істотну роль в житті людей. Вони служать джерелом їжі, беруть участь в спиртовому бродінні, $є$ продуцентами антибіотиків, ферментів і інших біологічно активних речовин. Багато грибів, найчастіше мікроміцети, паразитують на рослинах, рідше на різних органах людини і тварин, 
викликаючи у них різні мікози. Дереворуйнуючі гриби можуть бути причиною пошкодження і загибелі живих дерев [2].

Базидіальні макроміцети-ксилотрофів - одна з найважливіших трофрічних груп грибів, які грають в лісових екосистемах величезну роль. Грибиксилотрофів здійснюють поетапне розкладання лігніно-целюлозних комплексів деревини, сприяють утворенню гумусу, а також трансформують в ланцюзі харчування через плодові тіла i комах-міцетофаги різні мікроелементи [3].

Мета роботи - виявити закономірності поширення макроміцетів рекреаційних зон м. Селидове Донецької області, вивчити їх видовий склад та сезонну динаміку плодоношення.

Застосовувалися маршрутний та стаціонарний методи, збір матеріалу проводився за допомогою фотографування.

В результаті наших досліджень було виявлено та ідентифіковано значну кількість макроміцетів. На ділянках, де зростали старі дерева дуба, берези, тополя, черемхи білої та деякі плодові дерева (основні мікоризоутворюючі породи в природних екосистемах) були виявлені гриби: Pholiota populnea, Fomes fomentarius, Cerioporus squamosus, Laetiporus sulphureus, Cerrena unicolor, Pleurotus ostreatus. Наявність такої значної кількості шапкових грибів цієї екологічної групи в штучних насадженнях свідчить проте, що екосистема цих парків вже сформувалася і $€$ більш стійкою до негативних впливів зовнішнього середовища. Вочевидь, що кругообіг речовин у парку підтримується природнім шляхом, і досліджені екосистеми мають нині певну стабільність. Так, у деяких місцях парку де є загущені ділянки, де багато сухих гілок, стовбури дерев мають різні ушкодження.

Досліджено що Basidiomycetes у парку міста Селидове переважно належать до сапротрофрів та ксилотрофів. Переважно видовий склад макроміцетів росте на старих деревах, пнях але $€$ такі як трутовик лускатний він зустрічається на здорових рослинах так і на старих, сухих деревах. Церрена однокольорова на сухих старих деревах та пнях. Трутовик сірчаножовтий на пів зруйнованих деревах. Трутовик спражній на старих пнях, деревах та на здорових рослинах.

Висновки. Отримані дані добре ілюструють природне значення грибів у розкладі рослинних решток і забезпеченні кругообігу речовин у досліджених біоценозах парків: чим чисельніший видовий склад грибів, тим вони стабільніші і стійкіші до втручань ззовні. У Селидівському міському парку з'явилася значна кількість грибів-макроміцетів, що свідчить про заміну штучних насаджень на біоценози природного типу. Тому діяльність людини на об'єктах повинна бути помірною і спрямованою на підтримку і збереження вже існуючих у біоценозі зв'язків між рослинами і грибами, на попередження ушкоджень кори і гілок на деревах, що завадить їх зараженню паразитичними видами грибів, а також на догляд і лікування хворих дерев.

\section{Список використаних джерел:}

1. Акулов, О. Ю., Леонтьєв, Д. В. (2008). Гриби, занесені до Червоної книги України , 3 національного природного парку «Гомільшанські ліси». Укр. ботан. журн, (4), 586 - 589. 
2. Бабенко, О. Ю., Попова, Д. В. (2013). Нове місцезнаходження двох рідкісних видів макроміцетів в Північно-західному Причорномор'ї (Україна). Укр. ботан. Журн, ( 4), 547 551.

3. Бабенко, О. А., Ткаченко, Ф.П.(2012). Макроміцети регіонального ландшафтного парку «Тилігульский» (Одеська область). Біологічний вісник МДПУ, (22), 8 - 18.

\title{
ІНТЕНСИФІКАЦІЯ КАТАЛАЗНОЇ АКТИВНОСТІ ДЕЯКИХ ШТАМІВ БАЗИДІЄВИХ ГРИБІВ
}

\author{
НАУКОВО-ДОСЛІДНА ГРУПА: \\ Приседський Юрій Георгійович \\ Д.б.н., професор кафедри ботаніки та екології \\ Донецький національний університет імені Василя Стуса \\ Решетник Катерина Сергіївна \\ Старший викладач кафедри ботаніки та екології \\ Донецький національний університет імені Василя Стуса \\ Перестюк Юлія Станіславівна \\ Здобувачка вищої освіти факультету хімії, біології та біотехнологій \\ Донецький національний університет імені Василя Стуса
} УКРӒ̈НA

Актуальність вивчення базидієвих грибів обумовлена встановленням їх корисних властивостей, пошуком нових хімічних сполук, вивченням закономірностей і спрямованої регуляції метаболічних шляхів біологічно активних речовин.

Однією із галузей яка стрімко розвиваються в Україні та у багатьох інших країнах $€$ грибівництво $є$ джерелом різноманітних природних вітамінів C, D, E, групи В, містять антиоксидантний комплекс, клітковину, багато біологічно активних сполук. Гриби цінуються як дієтичний продукт через незначну кількість калорій, жирів з широким спектром практичного застосування, харчових добавок, грибних лікарських препаратів, біопрепаратів для захисту рослин тощо [1].

Ксилотрофні базидіомікотові здатні утворювати високоактивні кисневі радикали, які беруть участь у деструкції високомолекулярних речовин, в першу чергу фенольних сполук, лігніну, целюлози тощо. Передбачається, що вивчення механізмів такої деструкції може відкрити шляхи до розробки екологічно чистих енергозберігаючих біотехнологій біодеструкції та біоутилізації хімічно стійких відходів промисловості та переробки лігноцелюлозної сировини [2].

Велике значення в процесі деградації лігніну ксилотрофами відіграють реакції вільно-радикального окислювання, а також синтез цими грибами різних речовин окисно-відновної дії і біоантиоксидантів [3].

Аналіз робіт з вивчення механізмів фоторецепції у грибів, дозволяє зробити висновок про можливість використання світла для регуляції морфогенезу і 
біологічної активності грибів, що стане основою для створення екологічно чистих технологій їхнього культивування. Проте використання гелій-неонових лазерів, які мають значну енергоємність та великі габарити значно ускладнює технологію стимулювання процесів росту та розвитку грибів [4]. Тому використання світлодіодних лазерів, які мають невелику вартість та потребують незначних енерговитрат при застосуванні $\epsilon$ значно ефективнішим для інтенсифікації метаболічних процесів макроміцетів. Однак, вплив світлодіодних лазерних систем на ферментативну складову прооксидантноантиоксидантної системи макроміцетів обмежений і потребує подальшого вивчення.

Мета роботи - дослідити вплив лазерного опромінення на каталазну активність деяких штамів базидієвих грибів.

Для вивчення впливу лазерного опромінення перед інокуляцією міцелій у чашках Петрі розділяли стерильною сталевою трубкою на шматки розміром $5 \times 5$ мм, потім кожний інокулюм опромінювали за допомогою світлодіодних лазерів: BRP-3010-5, з випромінюванням червоного спектру з довжиною хвилі 635 нм, ВВР-3010-5 з випромінюванням синього спектру з довжиною хвилі 405 нм та BGP-3010-5 з випромінюванням зеленого спектру з довжиною хвилі 532 Hм (виробник BOB LASER Со., Китай). Потужність кожного лазера становила 100 мВт. Каталазну активність визначали у міцелії (водна витяжка, на одиницю маси, г) та культуральному фрільтраті (на одиницю об'єму, см³) спектрофотометричним методом.

Отримані результати дозволяють зробити висновок про відмінність вивчених штамів у активності каталази КФ та МГ. Встановлено, що лазерне опромінення синім та зеленим світлом тривалістю 10 сек веде до зростання каталазної активності культурального фрільтрату досліджуваних штамів базидієвих грибів. Дія червоного світла не викликає вірогідних змін активності ферменту у більшості вивчених штамів. Досліджено, що лазерне опромінення синім та зеленим світлом тривалістю 10 сек сприяє зростанню каталазної активності гомогенату міцелію досліджуваних штамів базидієвих грибів. Дія червоного світла також не викликає вірогідних змін активності фрерменту у більшості вивчених штамів. Порівняно реакцію штамів на лазерне опромінення та виявлено організми з максимальною активністю. Зокрема найбільшою реакцією у відповідь на опромінення характеризувався штам $F$ - 107 гриба Flammulina velutipes у відповідь на опромінення синім світлом. Так, показник каталазної активності культурального фрільтрату зріс на 120,41\%, а активність каталази міцелію зросла на $117,03 \%$ порівняно з контролем. Інші вивчені штами мали менш суттєві зміни каталазної функції у відповідь на дію опромінення.

Висновки. Таким чином, проведене нами дослідження фоточутливості базидієвих грибів до когерентного монохроматичного світла дозволило встановити загальні закономірності та індивідуальні особливості реакцій різних штамів на спектр світла і визначити ефективні параметри лазерної фотоактивації, які дозволяю значно підвищити каталазну активність.

\section{Список використаних джерел:}

1. Asatiani M.D, Elisashvili V, Songulashvil G,. Reznick A Z. \& Wasser S P. (2010). Higher basidiomycetes mushrooms as a source of antioxidants. Progress in Mycology Eds M. Rai, G. Kövics, 311-326. 
2. Asatiani, M.D, Elisashvili, V, Reznick, A.Z, Wasser, S. \& Nevo E. (2007). Antioxidant and freeradical scavenging activity of submerged mycelium extracts from aphyllophoroid mushrooms. Mycologia Balcanica, (4), 45-50.

3. Badalian, S.M, Serrano, J.J. Rapior, S, Andary, C. \& Med, J. (2010). Pharmacological activity of macroscopic fungi: Flammulina velutipes (Curt.: Fr.) Sing., Paxillus involutus (Batsch.: Fr.) Fr. and Tricholoma tigrinum Schaeff. (Basidiomycotina). Mushrooms, 171-172.

4. Badalyan, S.M, Med, J. (2010). Higher basidiomycetes as a prospective objects for mycopharmacological research. Mushrooms, (3), 108.

\title{
ОСОБЛИВОСТІ САНІТАРНО-МІКРОБІОЛОГІЧНОГО СТАНУ ЗАКЛАДІВ ГРОМАДСЬКОГО ХАРЧУВАННЯ М. КИЇВ
}

\author{
НАУКОВО-ДОСЛІДНА ГРУПА: \\ Машталер Олександра Володимирівна \\ канд. біол. наук, доцент кафедри ботаніки та екології \\ Донецький національний університет імені Василя Стуса \\ Решетник Катерина Сергіївна \\ старший викладач кафедри ботаніки та екології \\ Донецький національний університет імені Василя Стуса \\ Сичова Галина Сергіївна \\ Здобувачка вищої освіти фракультету хімії, біології та біотехнологій \\ Донецький національний університет імені Василя Стуса
} УКРӒ̈HA

Досвід багатьох країн світу свідчить про те, що вирішення проблеми якості та безпеки харчування не можливе без розробки і впровадження сучасної системи ЕН. Необхідними кроками у цьому напрямку $є$ прийняття єдиних критеріїв визначення неякісної їжі, порядок їх виявлення та державної реєстрації, лабораторне забезпечення розшифровування етіологічної структури окремих випадків та створення комп'ютерної бази даних для епідеміологічного аналізу та прогнозування поширення у закладах громадського харчування провідних збудників запальних інфекцій, появи у них фракторів патогенності та інших біологічних властивостей [1].

Таким чином, стратегія боротьби з неякісною їжею в Україні вимагає наукового обґрунтування підходів щодо мікробіологічного моніторингу за епідемічно значимими закладами громадського харчування, постійного стеження за домінуючими збудниками інфекціями, їх біологічними властивостями, підходів щодо визначення впливу фракторів ризику на розвиток інфекцій у відвідувачів закладів громадського харчування, а також контроль за поширенням штамів мікроорганізмів, які за певних умов можуть стати збудниками харчових отруєнь.

Крім того, важливим питанням сьогодення є розробка в Україні сучасної науково обґрунтованої системи ЕН за закладами громадського харчування, впровадження якої в закладах громадського харчування дозволить 
уніфікувати стандарти визначення випадків харчових отруєнь, сприятиме повноцінному проведенню оперативного і ретроспективного аналізу щодо епідемічної ситуації в закладах громадського харчування та країні в цілому, а також дозволить своєчасно розробити та здійснити ефективні заходи профрілактики і, насамкінець - знизити рівень харчових отруєнь та соціальноекономічних збитків від цих інфрекцій [2].

Мета роботи: аналіз санітарно-мікробіологічного стану закладів громадського харчування у м. Києві.

За даними служби з нагляду в сфрері захисту прав споживачів і благополуччя людини зростає загальна захворюваність населення, що багато в чому пов'язано 3 порушенням в харчуванні, погіршенням стану навколишнього середовища, зниженням якості життя [3]. Проблеми забезпечення якості та безпеки харчових продуктів і продовольчої сировини набувають загальнодержавне значення, так як пов'язані зі здоров'ям нації та безпекою країни. Відсутність в Україні та її регіонах цілісної і мобільної системи управління продовольчою безпекою підкреслює актуальність досліджуваного питання, особливо в контексті стратегії імпортозаміщення.

При мікробіологічному контролі 821 проби кулінарних виробів з підприємств громадського харчування у м. Києві, встановлено, що 60 зразків (7\%) не відповідають нормативним стандартам за вмістом БГКП та 6 проб (1\%) - за змістом S. aureus. Виявлено, що санітарно-показові мікроорганізми роду Salmonella становлять 0,5 \% від загальної кількості проб, Citrobacter - 0,7\%, Klebsiella-2,7\%, Enterobacter $-3 \%$, Proteus - 0,6 \% тa Staphylococcus - 0,7\%. Було виявлено наявність патогенної (0,5 \%) та умовно-патогенної $(7,5 \%)$ мікрофлори, від загальної кількості проб, які перевищують норми ДСП [4].

Висновки. Таким чином для ефективної організації управління якістю продукції і послуг, що надаються необхідно, щоб був не тільки ясно виділений об'єкт управління, але і щоб чітко були визначені категорії управління, тобто явища, що дозволяють краще усвідомити й організувати весь процес. Наведені відомості за анкетами свідчать про актуальність теми підвищення якості обслуговування на підприємствах харчування, і дозволяють робити висновки про те, що якість обслуговування безпосередньо впливає на вибір відвідувачів.

\section{Список використаних джерел:}

1. Базарбаев, С. Б. (2016). Сравнительная оценка методов выявления бактерій группы кишечных палочек и E. coli. Проблемы ветеринарной санитарии, гигиены и экологии, (1), 23-28.

2. Васильєва, М. А. (2015). Сучасні методи контролю безпеки і якості харчових продуктів. Питання нормативно-правового регулювання у ветеринарії, (4), 133-135.

3. Васильєва, М.А. (2019). Інноваційні підходи при оцінці біологічної безпеки харчових продуктів. Питання нормативно-правового регулювання у ветеринарії, (1), 229-232.

4. Васильєва М.А. (2015). Сучасні методи контролю безпеки і якості харчових продуктів. Питання нормативно-правового регулювання у ветеринарії, (3), 133-135.

5. ДСТУ 4261-2003 «Система управління безпечністю харчових продуктів. Вимоги». 


\section{ПАТОГЕННА МІКРОФЛОРА ЇСТІВНИХ БАЗИДІЄВИХ ГРИБІВ В УМОВАХ ПРОМИСЛОВОГО КУЛЬТИВУВАННЯ}

НАУКОВО-ДОСЛІДНА ГРУПА:

Приседський Юрій Георгійович

д-р. біол. наук, професор кафедри ботаніки та екології Донецький національний університет імені Василя Стуса

Решетник Катерина Сергіївна старший викладач кафедри ботаніки та екології Донецький національний університет імені Василя Стуса

Беспалько Альона Сергіївна здобувачка вищої освіти фракультету хімії, біології та біотехнологій Донецький національний університет імені Василя Стуса

УКРӒ̈HA

Станом на сьогодні гриби є дуже розповсюдженими і з кожним роком вчені відкривають все нові їхні характеристики, властивості та особливості. Шапинкові гриби, наприклад шампіньйони є дуже корисними і поживними. Гриби є незамінним джерелом білка [1]. На сьогоднішній день дуже популяризованим $\epsilon$ здорове харчування та відмова від тваринних жирів. А значить кількість джерел білків потрібно збільшувати. Культивування їстівних грибів $є$ гарантом запобігання отруєнь не їстівними грибами, зібраними за межами грибниць [2]. Оскільки гриби є сезонними організмати то доцільним $€$ їхнє культивування в промислових умовах на грибних фермах. Що дозволить отримувати велику кількість макроміцетів протягом року [3]. Проте в умовах промислового культивування існує небезпека зараження грибниць патогенною грибною мікрофлорою, що завдає значної шкоди виробництву та приносить значні економічні збитки. Тому доцільним $є$ вивчення патогенною мікрофлори базидієвих грибів та пошук ефективних методів боротьби з нею [4].

Мета роботи - дослідити патогенну мікрофрлору базидієвих грибів на прикладі гриба Agaricus bisporus та виявити найбільш єфективні методи боротьби з збудниками хвороб грибів в умовах промислового культивування.

Під час проведення досліджень було встановлено, що у процесі вирощування грибів на грибниці дуже впливовими чинниками на показник врожайності $€$ не тільки абіотичні чинники але й біотичні. Залежно від збудника хвороби шампіньйону можна умовно поділити на групи: грибкові, бактеріальні, вірусні. Всі ці хвороби виникають з декількох основних причин по-перше це не дотримання санітарно-гігієнічних норм робітниками грибниці, по-друге це порушення мікрокліматичного режиму в камері.

В результаті наших досліджень було встановлено , що найпоширенішим захворюванням грибів $є$ пліснява (цвіль). Нами було виявлено кілька типів паразитичної цвілі, кожен з яких вимагає особливого лікування і профілактики. Наприклад, при певних умовах на грибах з'являлася борошниста роса. Вона розвивалася за умов підвищеної вологості і температури. Однак ознаки зараження з'являлися тільки на останніх стадіях розвитку. У деяких випадках 
зараження відбувалося не спорами, а їх частинами, тому хворобу виявляли ще раніше. Крім самих грибів, борошниста роса вражала і покрив грунту.

Іншим патогенним грибом, який ми виявили була мокра гниль (мікогоноз) (Mycogone perniciosa). Вона викликала порушення процесу плодоутворення печериці. Під впливом збудника замість нормального плодового тіла утворювалася безформна маса до 10 см в діаметрі. Уражені плодові тіла через кілька днів темніли і швидко розкладалися під дією збудника, гнильних бактерій і нематод. На поверхні уражених плодових тіл виступали краплі бурого ексудату. При ранньому зараженні захворювання характеризувалося високою шкідливістю. Поява мікогонозу до першого збору врожаю грибів або під час першої хвилі плодоношення вказує на те, що основним джерелом інфекції $€$ покривний матеріал. В результаті проведених досліджень найбільш ефеекивними виявилися наступні методи боротьби:

1. Дотримання гігієнічних норм на виробництві (дезінфеецція одягу ,зміна рукавичок, миття тари та ін.)

2. Механічні способи боротьби полягають в тому, що як тільки виявлено місце де з'явилась хвороба необхідно зібрати кожний уражений гриб та засипати місце сіллю.

3. Хімічний спосіб боротьби полягає в використанні фунгіцидів наприклад міраж або споргон, які використовуються ще на початку циклу та між хвилями.

Висновки. В результаті проведених досліджень було вивчено патогенну мікрофрлору базидієвих грибів на прикладі гриба Agaricus bisporus та виявлено найбільш ефективні методи боротьби з збудниками хвороб грибів в умовах промислового культивування.

\section{Список використаних джерел:}

1. Curvetto, N., R. Gonzalez-Matute, D. Figlas, S. Delmastro, J.E. Sanchez \& G. Huerta, E. (2012). Montiel Sunflower seed-based medium for growth of Ganoderma spp. Mushroom Biology and Mushroom Products - Cuernavaca, (4), 205-212.

2. Dai Yu-Ch., Zh-L. Yang, B-K. Cui, Ch-J. Yu. (2009). Species diversity and utilization of medicinal mushrooms and fungi in China (review). Int. J. Med. Mushr., (11), 287-302.

3. Davis J. (2012). Inactivation of antibiotic and the dissemination of resistance genes. Science, (264), 375-382.

4. Davitashvili E., E. Kapanadze, E. Kachlishvili [et al.] (2008). Evaluation of higher Basidiomycetes mushroom lectin activity in submerged and solid-state fermentation of agro-industrial residues. Int. J. Med. Mushr., (10), 173-178. 


\section{TВЕРДОФАЗНЕ КУЛЬТИВУВАННЯ PLEUROTUS OSTREATUS НА ВІДХОДАХ ЧАЮ}

\section{Мельник Олег Михайлович}

Здобувач вищої освіти фракультету хімії, біології та біотехнологій Донецький національний університет імені Василя Стуса

Науковий керівник: Решетник Катерина Сергіївна

Старший викладач кафедри ботаніки та екології Донецький національний університет імені Василя Стуса

УКPAÏHA

У сучасному світі все розвивається швидкими темпами. Розвиток відбувається у всіх напрямках: різних видах бізнесу, сорері обслуговування, індустрії нерухомості. Стрімкий розвиток, на сьогодні, спостерігається у напряму екології. Відомо, що чай містить понад 120 поживних речовин. Всі ці поживні елементи так само присутні, та у меншій кількості, і у їх відходах, що саме головне, їх можна використовувати як субстрат. Середній хімічний склад чорного байхового чаю такий (\%): вода 8,5; білки - 20,0; моно- і дисахариди - 4,0; клітковина - 11,0; мінеральні речовини - 5,5; органічні кислоти (у перерахунку на яблучну кислоту) - 1,2. Крім того, в чаї містяться френольні сполуки, ефірні масла, алкалоїди, вітаміни, пігменти, пектинові речовини і ферменти. Чайний листок містить 75-80\% вологи, тоді як вологість зеленого і чорного байхового чаю складає 7-8\% [1].

Субстратом для твердофазного культивування було обрано відходи чаю. Підготовку та стерилізацію субстрату проводили загальноприйнятими методами [2]. Субстрат зважували зволоженими та змішували з додаванням 3 мл води.

3 метою вивчення впливу хімічного складу субстрату на ріст, міцелій штаму P - 191 культивували протягом 7 днів у стандартних чашках Петрі (діаметром 9 см). 3 метою оцінки росту культур вищих базидіоміцетів використовували метод заснований на дослідженні та аналізі динаміки збільшення радіусу колоній від часу культивування. Швидкість радіального росту - Vr визначали формулою [3]:

de:

$$
V r=\frac{a-b}{t_{1}-t_{0}}
$$

a - радіус колонії наприкінці росту, мм;

b-радіус колонії на початку фази лінійного росту, мм;

$t_{1}-t_{0}-$ тривалість лінійного росту, діб.

Усі досліди проводили у трикратній повторюваності. Порівняння середніх значень проводили методом Даннета [4].

У результаті проведення дослідження було виявлено швидкість росту колонії штаму P-191 гриба $P$. ostreatus під час культивування на субстраті із відходів від чаю. Ріст міцелію на субстраті, який на 100\% складався з відходів чаю- 40,7士0,47 мм. Культура на субстраті з відходів від чаю утворювали щільний пухнастий шар міцелію білого кольору з добре вираженою радіальною 
зональністю, непрозорим шаром субстратного міцелію та повітряним міцелієм висотою 4-6 мм з розвиненими гіфами (рис. 1).

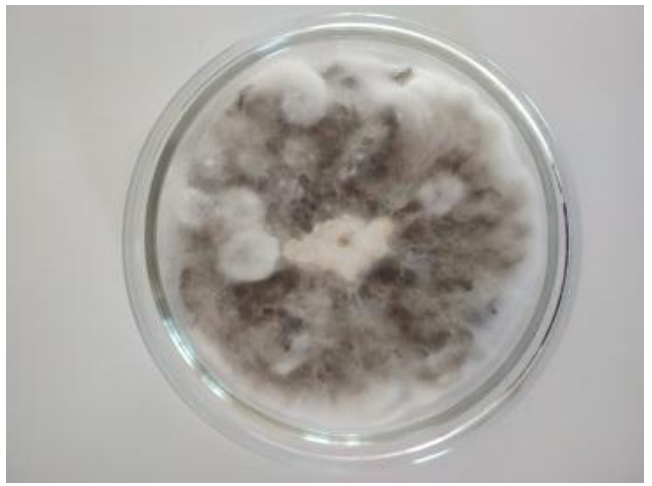

Рис. 1. Міцелій штаму Р-191 гриба $P$. ostreatus при культивуванні на субстраті із відходів від чаю (7 діб).

Отже, з отриманих результатів можна зробити висновок, що доцільно використовувати субстрат із відходів від чаю для твердофазного культивування макроміцета P. ostreatus.

\title{
Список використаних джерел:
}

1. Хімічний склад чаю. Вилучено з https://studopedia.org/6-21656.html

2. Buhalo, A. S., Bis'ko, N. A., Solomko J. F. \& Bilaj V. T. (2004). Kul'tivirovanie sjedobnyh $i$ lekarstvennyh gribov. Chernobyl'interinform. Kyiv.

3. Билай, В. И. (1982). Методы экспериментальной микологии: Справочник. Київ: Наук. Думка.

4. Приседський, Ю.Г. (2005). Пакет програм для проведення статистичної обробки результатів біологічних експериментів. Донецьк: ДонНУ.

\section{ХАРАКТЕРИСТИКА ПОКАЗНИКІВ СЕРЦЕВО-СУДИННОЇ СИСТЕМИ ПІДЛІТКІВ В УМОВАХ СТРЕСУ}

\author{
Раковець Оксана Юріївна \\ кандидат біологічних наук, викладач \\ Луцький педагогічний коледж \\ УКРӒ̈̈А
}

Найважливішими функціональними та фрізіологічними змінами організму підлітків в умовах різних видів стресу, а особливо навчального, характеризується серцево-судинна система. Вважається, що переважання симпатичної іннервації підвищує адаптаційні можливості організму, робить їх більш пластичними [1]. 
Одним 3 критеріїв оцінки рівня стресорних впливів на організм людини $є$ використання як індикатор стресу кардіогемодинамічних показників [2], оскільки останні відображають енергетичний аспект будь-якого емоційного акту і можуть служити об'єктивною характеристикою навантаження, В тому числі психоемоційного та інтелектуального [3].

Згідно з даними сучасних дослідників [4], середня частота серцевих скорочень відображає лише кінцевий результат численних регуляторних впливів на систему кровообігу і характеризує особливості вже сформованого гомеостатического механізму. Аналіз же хронотропної функції серця, тимчасової тривалості кардіоінтервалів і їх варіабельності сприяє виявленню взаємодії і ступеня навантаження регуляторних механізмів серцевого ритму в тій чи іншій ситуації [2].

Традиційно в якості вегетативних корелятів психоемоційного стресу використовуютться два основних параметри діяльності серцево-судинної системи: частоту серцевих скорочень і величину артеріального тиску, а також похідний від цих величин показник - «вегетативний індекс Кердо», які дозволяють лише в найзагальніших рисах судити про співвідношення активності симпатичної і парасимпатичної систем при стресі. 3 впровадженням в практичну кардіологію математичного аналізу варіабельності серцевого ритму (ВСР) стало можливим вибірково визначати внесок симпатичного і парасимпатичного відділів у регуляцію процесів організму людини [3].

Численні дослідження показують, що під час іспиту значно підвищується частота серцевих скорочень, зростає артеріальний тиск, рівень м'язового і психоемоційної напруги. Після здачі іспиту фізіологічні показники не відразу повертаються до норми. Звичайно потрібно кілька днів для того, щоб параметри артеріального тиску повернулися до вихідних величин [5].

Таким чином, тривале і дуже значне емоційне напруження може призводити до активації симпатичного або парасимпатичного відділів вегетативної нервової системи, а також до розвитку перехідних процесів, що супроводжуються порушенням вегетативного гомеостазу та підвищеною лабільністю реакцій серцево-судинної системи на емоційний стрес.

\section{Список використаних джерел:}

1. Агаджанян, Н. А., Руженкова, И. В. \& Старинов, Ю. П. (1997). Особенности адаптации сердечно-сосудистой системы юношеского организма. Физиология человека. (23), 93-97.

2. Мухтарова, С. А. (2008). Психологическая характеристика подростка и некоторые особенности эмоциональной сферы. Взаляд в мир (1), 87-103

3. Ravenswaaij, C.A., Kollee L.A. \& Hopman J.C.V. (1993). Heart rate variability. Ann. Int. Med. (118), 436.

4. Heinen, I., Bullinger, M., \& Kocalevent, R. D. (2017). Perceived stress in first year medical students-associations with personal resources and emotional distress. BMC medical education, 17(1), 4.

5. Holinka, C. (2015). Stress, emotional intelligence, and life satisfaction in college students. College Student Journal, 49 (2), 300-311. 


\section{SECTION VII. SCIENCES MEDICALES}

DOI 10.36074/29.11.2019.v3.05

\section{CLINICAL RESULTS OF DENTAL TREATMENT IN CHILDREN UNDER GENERAL ANESTHESIA}

ORCID ID: 0000-0001-7348-8156

RESEARCH GROUP: assistant professor of the Department of Pediatric and Preventive Dentistry Bogomolets National Medical University (NMU)

ORCID ID: 0000-0002-1955-1297

Opanasenko 0. assistant professor of the Department of Pediatric and Preventive Dentistry Bogomolets National Medical University (NMU)

ORCID ID: 0000-0002-9457-1765

Mozgova 0. assistant professor of the Department of Pediatric and Preventive Dentistry Bogomolets National Medical University (NMU)

ORCID ID: 0000-0003-1898-8208

Savychuk 0.

professor of the Department of Pediatric and Preventive Dentistry Bogomolets National Medical University (NMU)

UKRAINE

The high prevalence of caries in children may be related to the lack of implementation of state-supported prevention programs in Ukraine, the lack of sanitation at various levels (individual, population, state), and reduced somatic health of the child. The problem of quality full mouth debridement is related to many factors and first of all to the psycho-emotional state of the child. One of the options for the rehabilitation of the oral cavity, especially in children of preschool age is the treatment of teeth under general anesthesia (medical sleep) [1,2,3,5]. The effectiveness of this method of remediation can be evaluated by long-term results [4].

Purpose of the study: to analyze of the results of full mouth debridement in children under general anesthesia for 3 years in children from 2 to 9 years.

Objectives of the study: to evaluate the effect of preventive measures after full mouth debridement in children under general anesthesia.

Materials and methods. In the period from 2014 to 2018, in the conditions of the Dental Medical Center of the O.O. Bogomolets National Medical University, 346 different aged children underwent complete mouth debridement by general anesthesia. During three years were tried to carry out preventive examinations (every 3 months) of this category of children. In the treatment of children, the anesthesiologist used drugs that provide not only effective, but also managed anesthesia and relaxation of the muscles of the maxillofacial area, and also do not give a pronounced depression in the post-anesthetic period.

Research results. Among 346 children, 187 were children aged 2 to 5 years, 109 were aged 5 to 9 years, the remaining 56 were children over 9 years of age. Thus, the largest percentage (54\%) was made up of children aged 2 to 5 years with 
unstable psycho-emotional state, $31.5 \%$ - children aged 5 to 9 years. In $89 \%$ of children from all surveyed, the indications for the general anesthesia in treatment were psycho-emotional state, and in $11 \%$ - these are diseases that affect the central nervous system (autism, cerebral palsy), CRA (mental retardation), schizophrenia, etc.).

In children treated by general anesthesia, the intensity of caries (DMF, df) ranged from 6 to 12. A significant percentage of complicated caries $(52 \%)$ were diagnosed with dental lesions. In total, 2,768 teeth were treated, including 2331 temporary teeth and 437 permanent teeth.

Among 2331 temporary teeth, 1121 were diagnosed with acute and chronic middle or deep caries (48\%), 908 had chronic fibrous pulpitis, the rest were chronic or exacerbation of chronic granulating periodontitis (302 teeth). Analysis of the temporary teeth lesions shows that first of all caries was diagnosed in the neck area of $52,51,61,62$ teeth, which made up the largest percentage $(68 \%)$ of all temporary examined teeth. Complicated caries (chronic fibrous pulpitis (57\%) and chronic or exacerbation of chronic granulating periodontitis (13\%). $21 \%$ are the first molars, among which were diagnosed $59 \%$ of teeth with caries the other teeth were with chronic fibrous pulpitis (31\%) and chronic or exacerbation of chronic periodontitis $(10 \%)$.

Among permanent teeth, the largest percentage was superficial or middle caries $(74 \%)$ in the first molars of the mandible.

In the treatment of teeth with general anesthesia, we used the traditional methods of treating caries and pulpitis using glass ionomer material for permanent filling. After the treatment, the parents were given recommendations regarding individual oral hygiene, the choice of oral hygiene products, and especially emphasized on preventive examinations, in the other words it is required to visit the dentist at least once every 3-4 months.

It was found that only $15 \%$ of parents listened to the recommendations of the dentist and visited him at least 3 times a year in order to carry out methods of preventing dental caries. With close interaction of parents and dentist with such children, psychological contact was established, stomatophobia was reduced and the possibility of preventive measures was created.

Among all children with temporary bite who were treated, it was found that the frequency of the fallout of fillings in the treatment of caries was 7\% after 6 months, $12 \%$ after a year, and $18 \%$ of all treated teeth after 2 years. Most often, the fallout of the fillings occurred in the teeth, which affected 2 or more surfaces. In the treatment of pulpitis in temporary teeth, the percentage of the fallout fillings after 6 months was $9 \%$, and after 1 year significantly increased - 15\%. It should be noted that after treatment of pulpitis of temporary teeth the percentage of complications after 6 months was $4 \%$, and after $1-2$ years - about $13 \%$. This may be due to errors in the implementation of complications in children with differential pulp diagnosis, which led to misdiagnosis and choice of inadequate treatment, or one of the possible reasons for not having a dentist visit for a preventive examination.

Most parents $(85 \%)$ did not accept the recommendations regarding the need for a regular visit to the dentist for preventive measures and overcoming stomatophobia, did not control the hygiene of the oral cavity, which often led to the need for re-treatment of children under general anesthesia (15\%) after 1.5-2 years. In children who did not visit a dentist for preventive purposes, the occurrence of new carious lesions was $69 \%$ after 1 year, and after $1.5-2$ years to $80 \%$. The increase in 
caries after 1 year in children whose parents visited a dentist for preventive purposes was about $12 \%$, and after $1.5-2$ years - up to $18 \%$.

Conclusion. After treatment with general anesthesia, dynamic monitoring of children is required at least once every 3-4 months for the purpose of preventive measures and overcoming stomatophobia in the child. When choosing filling materials, it is necessary to give priority to standard crowns (in case of destruction of 2 or more surfaces), composite materials of light curing (especially in case of damage to more than 3 surfaces of the tooth), glass-Ionomer cements can be used - in case of damage no more than one tooth surface (chewing). Professional hygiene is required, with a mandatory recommendation of using toothpastes with fluoride at least $1000 \mathrm{ppm}$. Parents should be advised to use floss or flossets to more thoroughly clean the approximate surfaces, in order to prevent the occurrence of approximate caries (from 4 years), especially during alternating occlusion. Parents should be encouraged to use additional mineralization of tooth surfaces at home (fluoride-containing rinses, Toth-Mousse, etc.). It must be explained that there is necessity of required mouth rinsing while receiving medicines in the form of syrups.

\section{References:}

1. Smoliar, N. I. \& Solonko, H. M. (2013). Urazhennia kariiesom postiinykh zubiv u ditei, yakykh likuvaly pid zahalnym znebolenniam. Ukrainskyi stomatolohichnyi almanakh, (27), 9-83.

2. Zablotskiy, Ya. V., Ugrin, M. M., Paykush, V. A. \& Solon'ko, G. M. (2010). Osobennosti provedeniya obshchego obezbolivaniya dlya stomatologicheskoy sanatsii detey $\mathrm{v}$ ambulatornykh usloviyakh. Klinicheskaya stomatologiya, (3), 52-54.

4. Smoliar, N. I. \& Solonko, H. M. (2013). Chastota uskladnenoho kariiesu molochnykh zubiv u ditei, yakym provodylas stomatolohichna sanatsiia pid zahalnym znebolenniam. Visnyk stomatolohii: naukovo-praktychnyi retsenzovanyi zhurnal, (3), 129-131.

5. Prokhno, O. I. \& Koval', P. B. (2012). Otdalennye rezul'taty lecheniya kariesa zubov u detey s psikhonevrologicheskimi otkloneniyami. Sovremennaya stomatologiya, (1), 66-68.

6. Kharitonova, M. P., Moseychuk, O. A., Krivtsov, S. L., Rusakova, I. V., Kontorshchikova, E. A. (2010). K voprosu okazaniya stomatologicheskoy pomoshchi detyam rannego detskogo vozrasta v usloviyakh ambulatornogo obshchego obezbolivaniya. Problemy stomatologii, (6), 12-15.

DOI 10.36074/29.11.2019.v3.06

CONDITION OF PSYCHOLOGICAL ADAPTATION OF FAMILIES OF PATIENTS WITH DEMENTIA

RESEARCH GROUP:

Hanna Kozhyna

Doctor of Medical Sciences, Professor, Head of the Department of Psychiatry, Narcology, Medical Psychology and Social Work Kharkiv National Medical University

Kateryna Zelenska Candidate of Medical Sciences, Associate Professor of the Department of Psychiatry, Narcology, Medical Psychology and Social Work Kharkiv National Medical University 
Olha Kaploukh

Postgraduate Students of the Department of Psychiatry, Narcology, Medical Psychology and Social Work Kharkiv National Medical University

UKRAINE

Topicality: Dementia (dementia) - acquired mental defect with a predominant disorder of intellectual function. It causes memory impairment, mental capacity, the ability to navigate time and space, as well as the ability to recognize people and objects. The ability to carry out daily activities and interact with others is also gradually diminishing. Among oa her things, the patient suffers from anger, suspicion and even out breaks of aggression. Subsequently, in addition to cognitive impairment, physical abilities are also damaged [1]. According to many authors, dementia is a major factor that limits the ability of older people. This conditionis considered one of the most difficult for the patient himself, and for his family and for society as a whole [2].

Objective. To determine the state of psychological adaptation of families of patients with dementia

Materials and Methods: We surveyed 59 families: 59 dementia patients and their families took part in the study. Patients were treated at KNPC Choir "Regional Clinical Psychiatric Hospital \# 3". The following psychodiagnostic methods were used in the study: questionnaire "Type of family attitude to therapy with psychotropic drugs" (NB Lutova, OV Makarevich, 2011), "Scale of a structured interview to determine the attitude of family members to illness (psychiatric diagnosis)) by a relative"(VA Abramov et al., 2009).

Results: we obtained the following results by the method "Scale of a structured interview to determine the relation of family members to illness (psychiatric diagnosis) in a relative" we obtained $49,15 \%$ of families with adequate attitude to the illness of a loved one, $18,64 \%$ from dramatic attitude to illness and $32.21 \%$ with negative (destructive) attitude to illness. According to the questionnaire "Type of family attitude to therapy with psychotropic drugs": the hostile type was in $15.25 \%$ of families, the removed type $-35.6 \%$ of families, manipulative type $-28.81 \%$, supporting un $-20.34 \%$.

Conclusions: Such data suggest that not all family members are able to correctly assess the illness of an elderly relative, so we consider it advisable in the future to develop a system of psychological support and correction of undesir able forms of attitude to the disease and treatment of psychotropic agents in patients and their family members.

\section{References:}

1. Pinchuk, I. Ya., Kolodiezhnyi, O. V., Drevitska, O. O., Myshakivska, O. M. \& Zdoryk, I. F. (2017). Psykhiatrychni tsentry dennoho dohliadu - Perspektyvnyi napriam rozvytku psykhiatrychnoi dopomohy [Psychiatric Day Care Centers - A Prospective Area for the Development of Psychiatric Care]. Arkhiv psykhiatrii, (23, 1 / 88), 74-75.

2. Shevchenko-Bitenskyi, K. V. (2019). Sotsialne funktsionuvannia patsiientiv $z$ haliutsynatornoparanoidnymy rozladamy pry zmishanykh dementsiiakh tiazhkoho stupenia vyrazhenosti [Social functioning of patients with hallucinatory-paranoid disorders in mixed dementia of severe severity]. Ukrainskyi visnyk psykhonevrolohii, (27, 3/ 100), 61-64. 
DOI 10.36074/29.11.2019.v3.07

\title{
FEATURES OF CLINICAL MANIFESTATIONS OF THE ANXIETY DISORDERS IN INTERNALLY DISPLACED PERSONS
}

\author{
RESEARCH GROUP: \\ Kateryna Zelenska \\ Candidate of Medical Sciences, Associate Professorof the Department of \\ Psychiatry, Narcology, Medical Psychology and Social Work \\ Kharkiv National Medical University \\ Tetiana Kraskovska \\ Postgraduate Students of the Department of Psychiatry, Narcology, \\ Medical Psychology and Social Work \\ Kharkiv National Medical University
}

Herman Berezhnyi Internship doctor of the Department of Psychiatry, Narcology, Medical Psychology and Social Work Kharkiv National Medical University

Hanna Zelenska Assistant of the Department of Physiology Kharkiv National Medical University

UKRAINE

Topicality. Mental health disorders in IDPs (internally displaced persons) are various and affect almost all areas of the psyche. The lack of positive motivation to move and the physical impossibility of further stay at homeland, traumatization of the psyche due to causes of migration, as well as the difficulties of adaptation to a new place determine the formation of specific experience of internally displaced persons [1]. The most common of these are anxiety disorders. Therefore, the relevance of the selected study is aimed at identifying key symptoms with the further development of new models of psychotherapy interventions in this population [2].

Objective: To determine the features of anxiety symptoms in IDPs compared to the same indicators among Kharkiv residents

Materials and methods: the study was conducted on the basis of KNP CHOR \&quot; Regional Clinical Psychiatric Hospital №3\&quot;. A comprehensive examination was conducted of 44 patients with anxiety disorders, both sexes, aged $20-55$ years. The main group consisted of 19 sick IDPs, control -25 patients who permanently reside in Kharkiv region. We have used the following psychodiagnostic techniques: the Hospital Anxiety and Depression Scale (HADS) (Zigmond A.S., Snaith R.P., 1983); Spielberger - Yu.L. Hanina (State - Trait Anxiety Invertory STAI, 1985).

Results: The following HADS data was obtained: $26.31 \%$ of displaced persons and $37.5 \%$ of locals had subclinical anxiety, subclinical depression in $36.84 \%$ and $54.17 \%$ respectively; clinical manifestations of anxiety were $73.69 \%$ and $62.5 \%$, respectively, clinical manifestations of depression were $63.16 \%$ and $45.83 \%$, respectively. On the Self-Esteem Scale: Low anxiety was observed in $15.78 \%$ of 
displaced persons and $20.83 \%$ of locals; moderate anxiety in $26.31 \%$ and $50 \%$, respectively; expressed anxiety $-57.91 \%$ and $29.17 \%$ respectively.

Conclusions. The obtained results indicate that the severity of anxiety and depressive symptoms is higher in IDP patients, therefore more attention should be paid to psychotherapeutic interventions. The obtained data allow us to develop in future and implement a comprehensive system for the treatment of IDPs with anxiety disorders.

\title{
References:
}

1. Wray, N. R., James, M. R., Mah, S. P., Nelson, M., Andrews, G., Sullivan, P. F., Montgomery, G. W., Birley, A. J., Braun, A. \& Martin, N. G. (2007). Anxiety and comorbid measures associated with PLXNA2. Arch. Gen. Psychiatry, (64, 3), 318 - 326.

2. Martsenkovskyi, D. I. (2018). Vikovyi polimorfizm posttravmatychnykh stresovykh rozladiv ta depresii u ditei vnutrishno peremishchenykh osib z okupovanykh terytorii [Age-related polymorphism of post-traumatic stress disorders and depression in children of internally displaced persons from the occupied territories]. Arkhiv psykhiatrii, (24, 1/ 92), 15-20.

\section{GENERAL ASPECTS OF TELEMEDICINE IN UKRAINE}

\begin{abstract}
Alina Lesna
Applicant for Higher Education II Medical Faculty Kharkiv National Medical University

Scientific adviser: Gaponova E.

Senior Lecturer in the Department of Public Health and Health Management Kharkiv National Medical University

UKRAINE
\end{abstract}

Among the many problems of modern medicine, the unresolved health care dilemma remains the provision of highly qualified, publicly available timely care [1]. Difficulties in assisting in hard-to-reach areas (Japan or the Philippines, Norway or northern India), populations at large distances from leading territorial health centers (rural areas of the USA, Australia); can be solved with telemedicine [2]. As defined by the World Health Organization (WHO), telemedicine is a method of providing health care services where distance is a critical factor.

Aim: to analyze the current state, problems and prospects of further development of telemedicine in Ukraine.

Materials and methods. The basis of the work is the analysis of publications in the search engines PubMed, Hinari, statistics of the WHO think tank, open databases of documents of the Ministry of Health of Ukraine (Ministry of Health of Ukraine).

Results. The first steps in the development of providing quality medical care to any person, regardless of their location and social status in Ukraine, were made in 2006, when the National Public Organization was established Association for the Development of Ukrainian Telemedicine and eHealth, and in 2007 The State 
Clinical Scientific and Practical Center of Telemedicine of the Ministry of Health of Ukraine was established in the year.

The telemedicine network is now united by most of the regional medical institutions of the Ministry of Health of Ukraine, such as the Dnipropetrovsk Regional Clinical Hospital. In 2015, II Mechnikova conducted 85 video consultations and 15 consultations with leading specialists of European clinics were conducted in online communication at the Lviv Regional Children's Clinical Hospital "OHMATDIT".

The main normative legal document regulating the activity of telemedicine in the field of health care is the order of the Ministry of Health of Ukraine dated 26.03.2010 No. 261 "On the introduction of telemedicine in healthcare institutions". However, the basic draft Law on Telemedicine (No 10196 of 14.03.2012), submitted to the Verkhovna Rada, has not been adopted yet. New orders from the Ministry of Health, including 19.10.2015 № 681 "Regulations on the telemedicine office of the health care institution", which regulates the equipping of the telemedicine office, forms of accounting documentation "Request for telemedicine consultation", "Opinion of the consultant".

In addition to the problem of financing equipment and information channels for data transmission, for Ukraine the issues of teaching staff the basics of telemedicine, the legal framework on the responsibility of consultants in the medical process, protection of personal data transmitted through the Internet, the expansion of opportunities through the introduction of new remote monitoring programs as a specific the patient.

Conclusion. Despite its 15-year history, telemedicine is still in its development stages in Ukraine. But worldwide experience proves to be economical (reducing the cost of transporting patients / doctors in rural areas) and medical (in the USA, the number of diabetes patients reduced by half) the benefits of the use of modern digital technologies.

\section{References:}

1. Milne, R.G., Home, M. \& Torsney, B. (2016). SMS reminders in the UK national health service: an evaluation of its impact on «no-shows» at hospital out-patient clinics. Health Care Management Review, 31(2). 130-136.

2. The European health report. (2015). Targets and beyond - Reaching new frontiers in evidence. Denmark. 


\section{LEVEL OF ADAPTATION AND PERSONAL SELF-CONCEPTION IN PATIENTS WITH COSMETOLOGICAL PROBLEMS}

\section{RESEARCH GROUP:}

Hanna Kozhyna

Doctor of Medical Sciences, Professor, Head of the Department of

Psychiatry, Narcology, Medical Psychology and Social Work Kharkiv National Medical University

Marianna Markova

Doctor of Medical Sciences, Professor, Professor of the Department of

Psychiatry, Narcology, Medical Psychology and Social Work Kharkiv National Medical University

Mykhailo Yudin

Doctor of Medical Sciences, Associate Professor of the Department of Psychiatry, Narcology, Medical Psychology and Social Work Kharkiv National Medical University

UKRAINE

Topicality. Beauty is an aesthetic category that denotes perfection, the harmonious combination of aspects of an object in which the latter causes the observer aesthetic pleasure. Beauty is one of the most important categories of culture. The opposite of beauty is ugliness. The importance of beauty in psychology has several meanings: psychological - the formation of self-perception, self-esteem, body image and psychosocial - perception and acceptance by others, social success, competitiveness of physical resources, satisfaction with interpersonal relationships. The most important beauty for a woman is due to gender-role expectations and stereotypes.

Aim: To investigate the profile of self-esteem and adaptation in cosmetic patients.

Materials and methods: 286 women aged $34.2 \pm 4.7$ years were interviewed, who underwent cosmetic procedures in connection with acne disease and sought help from the SAN-CLINIC. We used a psychopathological and psychodiagnostic examination - a questionnaire for psychosocial adaptation by K. Rogers and R. Diamond. All the respondents were divided into 2 groups: group $A$ (with low selfesteem - 190 patients and group B (with high self-esteem) - 96 patients.

Results: According to the indicators on the psychosocial adaptation questionnaire of K. Rogers and R. Diamond, the following results were obtained in percentages: adaptation in group $A-57.7 \pm 5.4$ and in group $B-59.6 \pm 3.7$; selfacceptance in $A-55.9 \pm 8.7$ and $B-63.9 \pm 3.4$; acceptance of others in A - 58,5 \pm 5,4 and $B-65,6 \pm 5,4$; emotional comfort in $A-58,0 \pm 5,4$ and $B-60,3 \pm 4,4$; internality in $A-57,3 \pm 6,2$ and $B-59,6 \pm 3,6$; dominance in $A-56,4 \pm 4,3$ and $B$ $60,3 \pm 4,8$; escapism in $A-15.0 \pm 2.0$ and $B-14.4 \pm 2.4$.

Conclusions: The results obtained allow us to conclude that both groups had a rather low adaptation, acceptance of others and emotional comfort. But in the further 
study, these indicators were low due to the different components. Therefore, we can conclude that acne reduces the standard of living and adaptation in patients with both high and low self-esteem.

\title{
References:
}

1. Ishmuratov, A. T. (1996). Konflikt i zghoda [Conflict and consent]. Kyiv: Naukova dumka.

2. Kyrylenko, T. S. (2007). Psykholohiia: emotsiina sfera osobystosti. Kyiv: Lybid.

DOI 10.36074/29.11.2019.v3.09

\section{THE INTERRELATION BETWEEN BIOELECTRIC BRAIN ACTIVITY AND AFFECTIVE DISORDERS IN PATIENTS WITH EPILEPSY}

\author{
Iryna Strelnikova \\ Associate Professor \\ Kharkiv National Medical University \\ UKRAINE
}

Relevance. Epilepsy refers to common neuropsychiatric diseases with a persistent tendency to occur epileptic seizures, as well as the neurobiological, cognitive, psychological and social consequences of this pathology.

General practitioners pay attention directly to seizures as the most striking symptoms of this pathology, considering them priority, while the comorbid disorders in epilepsy, often accompanying this disease, remain poorly understood. And patients, accordingly, do not receive adequate specialized care. Affective disorders are among the most common comorbid disorders in epilepsy.

The purpose of the work is to study the interrelation between affective disorders and features of the bioelectrical activity of the brain, including the predominant localization of the epileptic focus.

Materials and methods. 103 patients (62 men and 41 women) were examined aged 25 to 48 years old with an established diagnosis of epilepsy, the precise localization of the lesion, and the duration of the disease not exceeding 10 years. In the attack-free interval, patients had affective disorders of varying severity. The work used clinical and psychopathological, clinical and anamnestic, electrophysiological research methods.

Research results and their discussion. In the attack-free interval, the following clinical variants of affective disorders were identified in patients with epilepsy: depressive disorders, affective reactions, dysphoria, and obsessive-phobic disorders. In $65.7 \%$ of the examined patients, focal seizures with localization of the lesion in the temporal or frontal region were found and in $34.3 \%$ - generalized seizures. Depending on the type of seizure, the patients were divided into 6 groups.

On the EEG, hypersynchronization was most often observed with simultaneous amplification of the delta and theta ranges of the EEG, local changes in the temporal regions, especially in the right hemisphere, which indicated a violation of the 
mesodiencephalic and limbic structures of the brain. During the period of hyperventilation (HV), a tendency toward activation of convulsive readiness (43.6 \pm $3.7 \%$ ) was recorded. After functional loads of varying degrees of severity, epileptic activity was recorded: adhesions, sharp waves, spike-wave, acute-wave-slow-wave complexes.

Conclusions. The data obtained can be of some importance for diagnosis, as well as for assessing the dynamics of affective disorders during active therapy and during the formation of remission, including the use of normotimics in combination with anticonvulsants in patients with affective symptoms.

\title{
References:
}

1. Elger CE, Helmstaedter C, Kurthen M. (2004). Chronic epilepsy and cognition. Lancet Neurol. 3 (11). 663-72.

2. Engel J. (2004). Jr The goal of epilepsy therapy: no seizure, no side effects, as soon as possible. CNS Spectr. (2). 95 - 97.

3. Kozhina H.M., Korostiy V.I., Strelnikova I.N. (2012). Sovremennye podhody k terapii bolnyh epylepsiey s affektivnymi i kognitivnymi narutheniami. [Modern approaches to the treatment of patients with epilepsy with affective and cognitive disorders] Mezhdunarodny nevrologicheckii zhurnal. 4 (50). 69-75.

DOI 10.36074/29.11.2019.v3.10

PSYCHOEDUCATION IN COMPLEX ASSISTANCE IN ANXIETYDEPRESSIVE DISORDERS IN SERVICEMEN WITH TRAUMATIC INJURIES OF EXTREMITY GREAT VESSELS

\author{
Vladislava Koshchii \\ Assistant professor \\ Kharkiv National Medical University \\ UKRAINE
}

Relevance. Rehabilitation of servicemen with traumatic injuries of the extremity great vessels, which is complicated by the occurrence of anxiety-depressive disorders, is not limited to the appointment of psychopharmacotherapy. The elimination of psychopathological symptoms should be combined with the creation of optimal conditions for further social functioning, improvement of quality of life, ability for independent activities.

This category of patients requires the development of comprehensive rehabilitation programs and their immediate implementation in the practice of institutions that assist this contingent of patients. Current researches confirm the important role of psychosocial intervention in the rehabilitation process. A special place in the structure of rehabilitation activities is occupied by psychoeducation with its great potential. The purpose of psychoeducation is to involve the patient in the process of actively changing their own behavior. This goal is specified in the form of prevention of relapses, increase of compliance. 
The purpose of the study is to evaluate the effectiveness of psychoeducational programs in the complex rehabilitation of servicemen with traumatic injuries of extremity great vessels, which is complicated by the occurrence of anxietydepressive disorders and to develop optimal approaches for their application.

Materials and methods. To achieve this goal, with informed consent with the principles of bioethics and deontology on the basis of the Military Medical Clinical Center of the Northern region of the Ministry of Defense of Ukraine, a comprehensive examination of 65 male patients, aged 18 - 47 years with traumatic injuries of extremity great vessels, complicated by the occurrence of anxietydepressive disorders.

All patients received regulated psychopharmacotherapy according to the standards of the Ministry of Health of Ukraine within the framework of providing a medical institution. The main group consisted of 37 patients who participated in a psychoeducational program developed on the basis of their own research. The control group consisted of 30 patients who received only standard regulated therapy.

Research results. In the main group against the background of complex therapy with the use of psychoeducational intervention, $79.2 \%$ of the patients managed to achieve a stable therapeutic effect, which persisted for 1 year, in $12.6 \%$ of the patients, the condition remained without significant dynamics and in $8.2 \%$ anxiety-depressive disorders were noted. In the control group, improvement was only in $56.6 \%$ of patients, and in $40 \%$ hospitalization was registered because of exacerbation of symptoms. Performance criteria were remission resistance, hospitalization, quality of life, anxiety and depression, and improvement in mental status.

Conclusions. The comprehensive approach in the rehabilitation of servicemen with traumatic injuries of extremity great vessels, which is complicated by the emergence of anxiety-depressive disorders, which included psychopharmacotherapy with the use of regulated therapy in combination with psychoeducational training, leads to the revival of social activities and successful resocialization of these patients. The obtained data shows that psychoeducation not only increases the volume of knowledge, increases confidence in the fight against the disease, but also solves the problem of social reintegration of the patient.

\section{References:}

1. Liang, M, et al. (2016). Feasibility study of emergency intervention for vascular injury outside the hospital. Mil Med Res, (3), 36.

2. Moore, L.J., et al. (2015). Implementation of resuscitative endovascular balloon occlusion of the aorta as an alternative to resuscitative thoracotomy for noncompressible truncal hemorrhage. $J$ Trauma Acute Care Surg, 79, (4), 523-30.

3. Trellopoulos, G, et al. J Cardiovasc Surg. Torino. (2012). Endovascular management of peripheral arterial trauma in patients presenting in hemorrhagic shock. J Cardiovasc Surg. Torino, 53(4), 495-506.

4. Liang, M, et al. (2015). A mobile minimally invasive interventional shelter: a new answer to onspot emergency treatment of large arterial injuries. Scand J Trauma Resusc Emerg Med, (23), 63. 


\section{SANITARY AND EPIDEMIOLOGICAL ASPECTS OF THE PROBLEM OF SYNANTHROPIC ORGANISMS IN KHARKIV CITY}

RESEARCH GROUP:

Olga Gerasimenko

Ph.D., Associate professor Department of Hygiene and Ecology № 1 Kharkiv National Medical University

Olha Bohachova

Ph.D., Senior lecturer Department of Hygiene and Ecology № 1 Kharkiv National Medical University

Vladyslava Sarkis-Ivanova

Assistant of professor Department of Hygiene and Ecology № 1 Kharkiv National Medical University

Nguyen Do To Uyen Department of Hygiene and Ecology № 1 Kharkiv National Medical University

UKRAINE

Introduction. In settlements, especially large ones, special conditions are created for the existence of animals, and they can have both positive and negative sides. Reducing the area of natural habitats of different species of fauna contributes to the settlement of less suitable biotopes, and the lack of conditions for temporary resting places forces animals to occupy new ecological niches.

Restriction of feed resources leads to the transition to the use of atypical foods. In urban biotopes, the nature of the use of the territory, the size of individual sites, and the rhythm of daily activity change, the influence of the anthropogenic factor as a factor of anxiety changes also. In ecology, the term "synanthropes" has emerged, that means wild animals, insects, plants that actively use the fruits of human life, and often live directly in a person's home.

Aim. To study and give hygienic assessment the problem of the most widespread synantropic organisms in Kharkiv city, and develop hygienic substantiation of measures of preventing epidemiological complications.

Materials and methods. To achieve aim of this study, there were used bibliosemantic method for summarizing the analysis of the international experience, data of persona recearches, and method of comparative analysis.

Results. As a result of centuries-old of adaptation, the existence of many species of wildlife became so closely connected with humans that they ceased to meet outside settlements, and were called "urbanists". Among them are a common pigeon (Columba livia), a city and field sparrow (Passer domesticus and Passer 
montanus), a house mouse (Mus musculus), rats (Rattus norvegicus), cockroaches - oriental (Blatta orientalis) and German (Blattella germanica), bedbug (Cimex lectularius).

Other synanthropic animals find the conditions in human settlements more favorable, and they are undoubtedly more near human habitats than in the wild. These include, first and foremost, numerous bird species - buckwheat, pebbles, magpies, crows, starlings, swifts. They have had behavior changes associated with either breeding in unusual but more comfortable conditions or facilitated acquisition.

Adaptation to life "in the shadow of man" is actively continuing today. Thus, in Kharkov over the last decades the population of bats has grown, numbering tens of thousands of animal units. Foxes are increasingly appearing in city parks. Not only in large parks, but also in small public gardens we can find squirrels and owls. Many wild ducks nest on the rivers and ponds of Kharkiv. An interesting example of synanthropization is the coming of new forms of mosquitoes adapted to year-round active living in the basements of large homes and in elevator shafts.

Synanthropic bird species are rarely perceived as the source of problems and the cause of material losses, but only as long as the population of feathered "neighbors" remains insignificant. Numerous bird flocks can cause discomfort to humans, disrupt the operation of electrical equipment (when nesting on towers and power line supports), cause damage to buildings and engineering installations in places of mass gathering of birds (nesting colonies, places of resting and overnights) [1].

Buckwheats builds its nests in urban parks making large noisy colonies that polute the soil so much that the restoration of vegetation is stopped (according to research, the buckwheat population in Kharkov fluctuates within 70-100 thousand individuals). Essential increase in the number of common magpie (Pica pica) allows you to call Kharkov " magpied city", unlike Kiev, where there are more crows.

However, there are also more serious problems - epidemiological and epizootic hazards. Birds can be carriers of many infectious diseases caused by germs and viruses, including parasitic ones (helminths that affect humans and pets). The most numerous populations are formed by feral pigeons, which, because of the huge number of infections they carry, Parks Commissioner of New York City Thomas P.F. Hoving called "winged rats" in 1966 [2].

According to studies from different countries, feral pigeons act as asymptomatic carriers of about 90 infectious diseases, 7 of which are dangerous to humans, especially chlamydia, salmonellosis and pseudotuberculosis (yersiniosis).

The most common are Chlamydia psittaci and Campylobacter jejuni. In the dung of birds or on their feathers, bacteria remain for up to 3 weeks. Human infection occurs after inhalation of dust containing dried particles of bird excrements, excretions from the beak or contaminated fluff particles. In addition, a large amount of pigeon dung and down is often accumulated in window air conditioners [3].

According to the analysis, germ Chlamydia psittaci was detected in $52.6 \%$ of the captured birds. Strains of this bacterium can be transmitted to humans and cause psittacosis. Chlamydia psittaci can also cause atypical pneumonia, arthritis, pyelonephritis, encephalomyocarditis. This chlamydia belongs to absolute agents of zoonosis, that is, the infection is transmitted to humans from the animal by droplet and air-dust way [4]. 
Campylobacter jejuni, which is present in $69.1 \%$ of the caught birds, causes abdominal pain, diarrhea, fever and general malaise in infected people. According to the FDA (U.S. Food \& Drug Administration), Campylobacter jejuni is currently the most common cause of bacterial diarrhea in humans. Moreover, C. jejuni causes more cases than Shigella spp. and Salmonella spp. taken together [5].

Thus, these infectious birds can be a significant threat to the health of the human population and, if not turned away, at least their numbers should be regulated. Pest control of birds should be carried out with the participation of qualified ornithologists who are thoroughly aware of the behavior features of concrete species of birds and the best ways to influence them.

In many countries, the numbers of these birds are diminished by feeding them feed, to which contraceptives are added. The drug is tested and does not affect humans and animals. This method is used in France, Italy, USA. In many metropolitan areas it is forbidden to feed pigeons in the streets of the city. Such prohibition exists in Paris, Rome, Venice, London, Munich, Hong Kong. The violation is subject to a fine (in Paris - 180 euros, in London - 200 pounds, in Venice - 600 euros).

In many cities in Germany, almost every building in the historic center has plastic black crows. Thanks to these moulages, in a year and a half the pigeons almost completely disappeared from the metropolitan areas. Also quite effective is the use of mechanical structures and elements that prevent the landing and movement of birds [6].

Acoustic and visual means of frightening birds that imitate the presence of a predator, as well as noise and visile interferences that disturb the orientation of birds in space, have been widely used on airfield landings.

Conclusion. An excessive increase in the number of synanthropic animals, in particular pigeons, can pose a serious problem to different aspects of human activity, first and foremost the threat of increased risk of infectious diseases.

Unfortunately, the city budget of Kharkiv doesn't provide funds for the use of effective methods of controlling the bird population in the city and the consequences of their presence. In this regard, given the large number of people who like to feed pigeons in the squares and parks of our city, it is recommended to follow carefully the rules of personal hygiene.

Namely: wash own hands and hands of baby with antibacterial soap or at least wipe with an antiseptic cloth even after feeding healthy birds. In no case should children be allowed to rub their eyes and nose with dirty hands, stick their fingers in their mouths, touch food - this is a direct way to spread the infection. When cleaning window air conditioners, wear a mask and gloves as a protection.

\section{References:}

1. Villalba-Sánchez, Carmen, De La Ossa-Lacayo, Alejandro, \& De La Ossa V, Jaime. (2015). DENSITY OF DOMESTIC PIGEONS (Columba livia domestica GMELIN, 1789) IN THE NEW PUBLIC MARKET OF SINCELEJO, SUCRE, COLOMBIA. Revista U.D.C.A Actualidad \& Divulgación Científica, 18(2), 497-502. Retrieved from http://www.scielo.org.co/scielo.php?script=sci_arttext\&pid=S012342262015000200023\&lng=en\&tlng=.

2. Jerolmack, C. (2013). The Global Pigeon. London: The University of Chicago Press, Ltd. ISBN 978-0-226-00192-0. 
3. Burt, S.A., Röring, R. E., Heijne, M. (2018). Chlamydia psittaci and C. avium in feral pigeon (Columba livia domestica) droppings in two cities in the Netherlands. Veterinary Quarterly, 38, 6366. Retrieved from https://doi.org/10.1080/01652176.2018.1482028.

4. Čechová, L., Halánová, M., Kalinová, Z., Čisláková, L., Halán, M., Valenčáková A. (2016). Detection of Chlamydia psittaci in feral pigeons (Columba livia domestica) in Slovakia and their characterization. Ann Agric Environ Med. 23(1):75-78. Retrieved from https://doi.org/10.5604/12321966.1196856.

5. Vázquez, B., Esperón, F., Neves, E., Carlos Ballesteros, J.L., Muñoz M. J. (2010). Screening for several potential pathogens in feral pigeons (Columba livia) in Madride. Acta Veterinaria Scandinavica; $\quad 52(1)$ : $45 . \quad$ Retrieved from https://www.ncbi.nlm.nih.gov/pmc/articles/PMC2898782/.

6. Есилевская, М. А. (2009). Городская орнитофауна Германии на примере Мюнхена. Чтения памяти А.П. Крапивного: материалы междунар. научн.конфр. посвящ. 80-летию со дня рождения просрессора А. П. Крапивного (Харьков, 4-5 декабря 2009 г.). 78-82. Харьковский национальный университет имени В.Н. Каразина.

DOI 10.36074/29.11.2019.v3.12

\section{THE DEGREE OF ADAPTATION DISORDERS IN CHILDREN FROM INTERNALLY DISPLACED FAMILIES}

RESEARCH GROUP:

Hanna Kozhyna

Doctor of Medical Sciences, Professor, Head of the Department of

Psychiatry, Narcology, Medical Psychology and Social Work Kharkiv National Medical University

Kateryna Zelenska Candidate of Medical Sciences, Associate Professor of the Department of Psychiatry, Narcology, Medical Psychology and Social Work Kharkiv National Medical University

Olena Samoilova

Assistant of the Department of Psychiatry, Narcology, Medical Psychology and Social Work Kharkiv National Medical University

UKRAINE

Topicality. The results of the research show that they are in the presence of people who are safe, and consider various negative medical and sociopsychological factors. Too vulnerable for all psychiatric trauma are children. Unformed of their psyche, low level feel that emotional reactions execute in them a higher severity of the response to the acting psychotrauma, which responds. This is relevant for this.

Material and methods. The study was conducted during the 2014-2016 years. With respect to the principles of bioethics examined 66 children and adolescents 718 years from families of internally displaced persons. Psychodiagnostic method PTSD scale. 
Results. The study found that children with RA from families of internally displaced persons with moderate severity of adaptation disorders (PTSD Scale Index $10.32 \pm 0.09)$ with the prevalence of the disease in boys (10.39 \pm 0.13 ); persons of $7-10$ years $(10.55 \pm 0.16)$ and city dwellers $(10.42 \pm 0.13)$. It was found that the majority of surveyed children from RA from families of internally displaced persons had moderate $(48.48 \%)$ and severe $(21.22 \%)$ degrees of adaptation disorder (respectively, PTSD $10.47 \pm 0.04$ and $12.58 \pm 0,09$ ).

Conclusions. The results show that indeed, displaced children have manifestations of adaptation disorders of varying severity. Therefore, aid should first and foremost reduce these manifestations and increase the compensatory mechanisms of this population.

References:

1. Vuhotskyi, L. S. (2004). Psykholohyia razvytyia cheloveka [Human Development Psychology]. Moskov: Smusl;:Эksmo.

2. Zakharov, A. Y. (1986). Kak preodolet strakhy u detei [How to overcome fears in children]. Moskov.

DOI 10.36074/29.11.2019.v3.13

THE IMPORTANCE OF PSYCHOEDUCATION PROGRAMS IN ALCOHOL DEPENDENCE PATIENTS

RESEARCH GROUP:

Hanna Kozhyna

Doctor of Medical Sciences, Professor, Head of the Department of

Psychiatry, Narcology, Medical Psychology and Social Work Kharkiv National Medical University

Kateryna Zelenska Candidate of Medical Sciences, Associate Professor of the Department of Psychiatry, Narcology, Medical Psychology and Social Work Kharkiv National Medical University

\section{Vasyl Lytvynenko}

Assistant of the Department of Psychiatry, Narcology, Medical Psychology and Social Work Kharkiv National Medical University

UKRAINE

Topicality. In recent years, among the population of Ukraine there is a significant increase in the consumption of alcoholic beverages and as a consequence - an increase in the number of patients with alcohol dependence [1]. According to WHO data for 2010, the average annual consumption of alcohol in Ukraine is about 13.9 liters of pure ethanol per year (more than 2 liters of spirits per month) per capita, including all persons 15 years and older [2]. 
Goal. evaluation of the effectiveness of psycho-educational programs in the system of psychosocial rehabilitation of patients with alcohol dependence.

Material and methods. On the basis of the Kharkiv Regional Clinical Narcological Hospital No. 9 and the Military Medical Clinical Center of the Northern Region, a comprehensive examination of 150 male patients aged 20 to 55 years with alcohol addiction syndrome was conducted. Psychodiagnostic techniques used in the work: AUDIT test, coping strategies in stressful situations.

Results. According to the results of the study, among the examined patients, persons with a persistent alcohol abuse were prevalent, the average AUDIT score in the main group was 4.0. Dangerous alcohol consumption was found in $35.2 \%$, high probability of alcohol dependence was found in $60.1 \%$. The system of rehabilitation of patients with alcohol dependence with the use of psychoeducation has been developed and tested. Against the background of psychoeducational activities, positive dynamics of stress-coping behavior was observed. After conducting rehabilitation measures, coping strategies aimed at solving problems were noted in $45.1 \%$ of the examined patients of the main group and $32.6 \%$ of people of the control group, coping strategies aimed at emotions were in $31.4 \%$ and $22.4 \%$ respectively, $15.9 \%$ and $32.6 \%$ respectively - at avoidance, $6.7 \%$ and $12.4 \%$ - at distraction.

Conclusions: Thus, in the course of work, the foundations and principles of psycho-education for the system of complex rehabilitation of men with alcohol dependence are formulated, the main purpose of which is to develop the patient's ability to independently solve their own problems of alcoholic genesis and prove their effectiveness.

\section{References:}

1. Slobodyanyuk, P. M. (2011). Zasadi ta naukove obGruntuvannya printsipiv i pidhodiv schodo formuvannya sistemi integrativnoyi psihoterapiyi alkogolnoyi zalezhnosti [Principles and scientific substantiation of principles and approaches for forming the system of integrative psychotherapy of alcohol dependence]. Ukrayinskiy visnik psihonevrologiyi, 19, 2(67), 92 - 96.

2. Voloshin, P. V., Maruta, N. O. (2017). Osnovni napryamki naukovih rozrobok v nevrologiyi, psihiatriyi ta narkologiyi $v$ Ukrayini [Main directions of scientific development in neurology, psychiatry and narcology in Ukraine]. Ukrayinskiy visnik psihonevrologiyi, 25, 1(90), 10 - 18. 


\section{THE STATE OF COLLECTIVE IMMUNITY TO THE VIRUS OF THE MEASLES OF THE POPULATION IN KIROVOGRAD REGION 2016-2018}

State Institution "Kirovograd regional laboratory Center of the Ministry of Health of Ukraine»

Scientific adviser: Victoria Zadorozhna

State Institution «L.V. Gromashevsky Institute of Epidemiology and Infectious Diseasesof the NAMS of Ukraine»

UKRAINE

Introduction. The spread of viral infectious diseases with the pathogen transmission is one of the most important problems of today. Not only have infectious diseases not lost their relevance, but they still pose a threat to humanity. In recent years, there has been an increase in infectious pathology of viral etiology, especially measles.

According to world medicine research, immunization is the best method of reducing infectious disease for vaccine-controlled infections by achieving a high level of specific immunity. Vaccination plays a particularly important role in the prevention of infectious diseases. Immunization saves millions of people every year in the world and prevents them from becoming disabled. At the same time, the epidemic process of viral infections with the pathogen transmission is the most difficult to control, thus complicating the achievement of the WHO global goals for eradication / elimination of the pathogen, periodically postponing the timing and timing of implementation of global programs to combat these infections.

An example is the incidence of measles with a tendency to increase recently, the elimination period of which has been extended to the end of 2020. Despite the fact that the number of measles cases in the world from 2000 to 2013 decreased by 67.6\% (from 863479 to 279 776), in Europe - by 34\% (from 37421 to 24689 ) the estimated number of fatal measles cases in the world in 2013 was 145700 , in Europe - $100[1,3,4,6]$.

The problem of measles remains urgent in the Kirovograd region. Short between epidemic periods of measles incidence ( 3 - 5 years), increase of patients among the older age groups (30\% of patients), registration of the disease among documented immunized persons ( $25 \%$ of patients), impaired immunization for various reasons (35\% of cases) patients) - all this has led to an increase in the number of people susceptible to measles virus and, consequently, to an increase in the incidence in the Kirovograd region: in 2016, the intensive indicator was 0.1 ; in $2017-1.87$ per 100 thousand population; in 2018 - 45.35 per 100 thousand population.

The purpose of the study. To analyze the state of collective immunity to measles virus by age groups: among children and adults for 2016 - 2018 and to assess the level of immunological response (the concentration of antibodies in blood serum at the time of examination in international units $/ \mathrm{ml}-\mathrm{IU} / \mathrm{ml}$ ) according to the results of laboratory studies.

Materials and methods: Data from the official statistical reporting of the state 
institution "Kirovograd Regional Laboratory Center of the Ministry of Health of Ukraine" (forms №1, № 2, № 40), demographic annual indicators of the State Statistics Service of Ukraine and the Main Department of Statistics in Kirovograd region.

The studies were performed by enzyme-linked immune sorbent assay (ELISA) using a set of reagents for the quantitative determination of class $G(\lg G)$ immunoglobulin against measles virus in human serum from Vector-Best, Novosibirsk. The results were recorded using a SUNRISE RS spectrophotometer, manufactured by BIO-RAD. According to the instructions to the set of reagents considered positive serum samples, if the concentration of $\mathrm{lgG}$ to the measles virus is equal to or greater than $0.18 \mathrm{IU} / \mathrm{Im}$, negative - less than $0.12 \mathrm{lU} / \mathrm{ml}$, doubtful $0.13-0.18 \mathrm{lU} / \mathrm{ml}$.

Among the positive results were the concentrations of $\operatorname{lgG}$ in IU / $\mathrm{ml}$ : less than 1 $\mathrm{IU} / \mathrm{ml}$ - low, 1 - $4 \mathrm{IU} / \mathrm{ml}$ - medium and $5 \mathrm{IU} / \mathrm{ml}$ and above - high.

Results and discussion: In Ukraine, since 2017, there has been a sharp intensification of the epidemic process of measles. In 2017 - 2018 in the country, incl. and in the Kirovograd region, high levels of measles incidence continue to be recorded (Table 1).

Table 1

Dynamics of measles incidence among the population of Ukraine and Kirovograd region (per 100,000 populations) in 2016 - 2018

\begin{tabular}{|c|c|c|c|c|}
\hline \multirow{2}{*}{ Years } & \multicolumn{2}{|c|}{ Kirovograd region } & \multicolumn{2}{c|}{ Ukraine } \\
\cline { 2 - 5 } & $\begin{array}{c}\text { Absolute } \\
\text { number }\end{array}$ & $\begin{array}{c}\text { Indicator } \\
\text { per } 100 \text { thousand } \\
\text { population }\end{array}$ & Absolute number & $\begin{array}{c}\text { Indicator } \\
\text { per 100 thousand } \\
\text { population }\end{array}$ \\
\hline 2016 & 1 & 0,1 & 102 & 0,2 \\
\hline 2017 & 18 & 1,9 & 4782 & 11,2 \\
\hline 2018 & 434 & 45,4 & 53219 & 125,5 \\
\hline Total & 453 & & 59465 & \\
\hline
\end{tabular}

An evaluation of the immunological structure of the population's immunity to measles allows the identification of at-risk populations among the vaccinated population and their immune correction in a timely manner to maintain epidemic well-being.

According to the recommendations of the World Health Organization (WHO) on the permissible\% of measles-susceptible persons in different age groups, epidemic well-being is indicated by measles-susceptible persons in different age groups, namely: up to $15 \%$ among children aged 5 years; up to $10 \%$ - up to 10 years and not more than $5 \%$ - among children older than 10 years and adults $[2,5,6]$.

Significant criteria were taken into consideration when selecting individuals for immunological monitoring: documentary confirmation of measles vaccination data, absence of a history of measles disease transmitted, absence of contact with measles patients during the last 12 months, consent of the subject or his parents to determine immunity, completed questionnaire, etc. [2]. In the study of immunity against measles, children who suffered from measles were not examined; lacking documentary evidence of measles immunization; who had gross violations of the preventive vaccination calendar, not vaccinated who have had contact with measles patients in the last year. All children had documented confirmation of vaccination with combination PDA vaccines, of which the proportion of vaccinated Priorix 
vaccine was $80.5 \%$ and Trimovax $19.5 \%$, which was confirmed in forms №63 / o, №112 / o.

According to industry statistics (40-healthy form), levels of specific IgG antibodies to measles virus were analyzed in 744 people in the Kirovograd region, 217 of whom lived in cities $(29.2 \%)$ and $527(70.8 \%)$ in rural areas (Table 2). All surveyed were conditionally divided into 3 age groups: children - 648 people $(87.1 \%)$, adolescents - 49 people (6.6\%), adults 18 years and older - 47 people $(6.3 \%)$.

Table 2

State of anti measles immunity in the vaccinated population of Kirovograd region in the period 2016 - 2018 (ELISA).

\begin{tabular}{|c|c|c|c|c|c|c|c|}
\hline \multirow{3}{*}{ Years } & \multirow{3}{*}{$\begin{array}{l}\text { Amounts } \\
\text { of serum }\end{array}$} & \multicolumn{6}{|c|}{ Levels of titer of antibody (IgG) } \\
\hline & & \multicolumn{2}{|c|}{ Seronegative } & \multicolumn{2}{|c|}{ Below Protective } & \multicolumn{2}{|c|}{ Protective } \\
\hline & & Абс.4. & $\%$ & Абс.ч. & $\%$ & Абс.ч. & $\%$ \\
\hline 2016 & 252 & 11 & 4,4 & - & - & 241 & 95,6 \\
\hline 2017 & 246 & 14 & 5,7 & - & 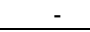 & 232 & 94,3 \\
\hline 2018 & 246 & 8 & 3,2 & 2 & 0,8 & 236 & 96,0 \\
\hline Total & 744 & 33 & 4,4 & 2 & 0,3 & 709 & 95,3 \\
\hline$\underset{\%}{\left(\mathrm{M}_{ \pm} \mathrm{m}\right)}$ & & & $4,4 \pm 0,7$ & & $0,3 \pm 0,2$ & & $95,3 \pm 0,8$ \\
\hline
\end{tabular}

Among those surveyed, the positive result (IgG concentration equal to or greater than $0.18 \mathrm{IU} / \mathrm{ml}$ ) was $95.3 \%$. In particular, the proportion of children protected by measles is $88.0 \%$ ( 624 persons), adolescents $-6.1 \%$ (43 persons), adults 18 years and older $-5.9 \%$ (42 persons).

Among the surveyed specific gravity with negative result (IgG concentration less than $0.12 \mathrm{lU} / \mathrm{ml}$ ) is $4.4 \%$. Of these, children - $72.7 \%$ (24 persons), adolescents $18.2 \%$ (6 persons), adults 18 years and older $-9.1 \%$ (3 persons).

Among measles-protected with low serum $\lg$ concentrations were most commonly observed in adults 18 and older, $0.3 \%$.

Thus, children over 10 years of age, adolescents aged 15-17 years and adults are at risk for disease and maintaining the epidemic process of measles in the Kirovograd region. A strong correlation was found between the high incidence of measles and seronegative prevalence among the vaccinated population $(r=-0.7$; Student's t-test value 2.1 ; at $P<0.05$ ). Decreased anti measles immunity leads to a gradual increase in the number of measles patients.

Conclusions. In the Kirovograd region, between 2016 and 2018, 95.3\% of the surveyed residents are measles protected; $4.4 \%$ - unprotected. The relatively high percentage of protected persons is a consequence of the recent years of measles immunization. Among the measles protected, the highest percentage is for children under 14 years. Among the unprotected measles, the highest percentage is adolescents aged 15-17 years. The concentration of immunoglobulin class $\mathrm{G}$ in serum decreases with age. The state of collective immunity to measles virus among the population of the Kirovograd region needs further in-depth study and research.

\section{References:}

1. World Health Organization. (2015). Infection Prevention and Control of Epidemic and Pandemic. Prone Acute Respiratory Infections in Health Care. Retrieved from www.who.int/csr/bioriskreduction/infection_control/publication/en/. 
86 - Problèmes et perspectives d'introduction de la recherche scientifique innovante $\bullet$ Volume 3

2. Про затвердження методичних вказівок «Організація проведення імунологічного моніторингу за інфрекціями, які контролюються засобами специфічної профілактики (дифотерія, правець, кашлюк та кір)» (Наказ МОЗ України), №441 від 04.07.2006.

3. World Health Organization. (2009). Weekly epidemiological record. Measles vaccines: WHO position paper. Retrieved from http://www.who.int/wer.

4. Задорожна, В. І. (2008). Дитячі інфекційні хвороби та перспективи сучасної вакцинології (за матеріалами 5-го Світового конгресу Міжнародного товариства з дитячих інфекційних хвороб). Профілактична медицина, (2), 63-68.

5. Голубкова, А. А., Платонова, Т. А. \& Харитонов, А. Н. (2018). Вакцинопрофилактика кори и пути ее оптимизации на завершающем этапе элиминации инфекции. Public health organization, (4), 91-94.

6. World Health Organization. (2019). Коревые вакцины: документ по позиции ВОЗ. Retrieved from www.who.int/immunization/documents/positionpapers/en/index.html.

DOI 10.36074/29.11.2019.v3.15

\section{THE STRUCTURE OF COMPUTER ADDICTION IN YOUNG PEOPLE}

\section{RESEARCH GROUP:}

Hanna Kozhyna

Doctor of Medical Sciences, Professor, Head of the Department of Psychiatry, Narcology, Medical Psychology and Social Work Kharkiv National Medical University

Kateryna Zelenska Candidate of Medical Sciences, Associate Professor of the Department of Psychiatry, Narcology, Medical Psychology and Social Work Kharkiv National Medical University

Yuliia Starodubtseva Postgraduate Students of the Department of Psychiatry, Narcology, Medical Psychology and Social Work Kharkiv National Medical University

UKRAINE

Topicality. The situation associated with addictive behavior is quite problematic for many countries in the world, including Ukraine [1]. The reason is the radical difference between the stereotypes of thinking and the outlook of successive generations brought up in different socio-economic conditions, as well as through a protracted political, economic and social crisis [2].

Aim: studying the structure of computer addiction in young people.

Materials and methods for achievement of the set purpose with observance of principles of bioethics and deontology during 2016-2018 on the basis of the Kharkov Regional Clinical Psychiatric Hospital No. 3 and in the Military Medical Clinical 
Center of the Northern region, the complex examination of 147 patients with adaptive disorders was performed (F43.21, F43.22). The average age of the examined people to $27.0 \pm 3.0$ years. We used a psychopathological and psychodiagnostic examination - AUDIT-like tests.

The results of the study. The structure of computer dependence in the examined people of the main group consisted of obsessive surfing (Internet surfing, search for information on databases and search sites) $-45.8 \%$ of the surveyed, $22.3 \pm 1.2 \%$ computer games; $5.8 \pm 0.4 \%$ virtual dating; $14.1 \%$ passion for online gambling; $1.2 \%$ cyberex (using porn sites). As the results of the clinical anamnestic study showed, the duration of the addition inthe examined people isthe following: up to one year $-45.8 \%, 1-3$ years $-36.4 \%$, more than 3 years $-17.6 \%$.

Conclusions: The purpose of our further work in relation to the obtained results will be to determine the value of these indicators for the level of adaptation with the further development of psychoeducational and psycho-corrective programs.

\section{References:}

1. Kozhina, G. M., Krasnikova, S. O., Gaychuk, L. M. \& Zelenska, K. O. (2011). Spetsifika adaptatsiynih reaktsiy studentiv pershogo kursu do navchalnoyi diyalnosti u vischomu navchalnomu zakladi [Specificity of adaptive reactions of students of the first year of study to educational activity in a higher educational institution]. Medichna psihologiya, 6, 3(23), 14 - 17.

2. Dale, J. Terasaki, Bizu, S. Gelaye \& Yemane, Berhane. (2009). Anger expression, violent behavior, and symptoms of depression among male college students. BMC Public Health, 9, 13, $1-25$.

\section{АЛЛОПРЕГНАНОЛОН, ЯК ОДИН ІЗ ПРИЧИН РОЗВИТКУ АУТИЗму}

Сечко Аліна Олегівна

здобувач вищої освіти медичного факультету Харківський національний медичний університет

УКРAÏHA

Аллопрегнанолон гормон, що виробляється плацентою на пізніх термінах вагітності, $€$ таким сильнодіючим нейростероідов, що порушення його виділення може призвести до травм головного мозку, пов'язаних з розладом аутистичного спектру. Аллопрегнанолон починає різко зростати в другому триместрі вагітності. Коли діти народжуються недоношеними, їх запас аллопрегналона різко припиняється. Втрата аллопрегнанолону призводить до довготривалих структурних змін мозочка - області мозку, яка необхідна для координації рухів, балансу і соціального пізнання, і тим самим збільшує ризик розвитку аутизму [1]. Зі структурної точки зору найбільш виражені аномалії мозочка з'являються в білій речовині, також були виявлені збільшення 
товщини мієліну, багатого ліпідами ізолюючого шару, який захищає нервові волокна. 3 поведінкової точки зору при скороченні запасів аллопрегнанолону, з'являється підвищена повторювальна поведінка і дефріцит комунікабельності - дві ознаки у людей з розладом аутистичного спектру. Ці порушення розвитку мозку можна запобігти, запровадивши всього одну ін'єкцію аллопрегнанолона під час вагітності. Це мається на увазі, що гормон грає важливу роль у формуванні мозку плода, і добавки цього з'єднання можуть запобігти порушенням [2].

Однією 3 основних причин раптового десріциту активності аллопрегнанолона в головному мозку є передчасні пологи - випадок, який зустрічається приблизно у $10 \%$ дітей. Передчасні пологи визначаються як пологи до 37 завершених тижнів вагітності. Порушення функції плаценти на ранніх термінах вагітності може піддавати плід ризику довготривалих порушень, оскільки плацента грає кілька важливих ролей в розвитку нервової системи. 3 одного боку, вона поставляє певні гормони, необхідні для нормального розвитку мозку плода. По-друге, він випускає певні клітинні хімічні сигнали, які викликають запалення в мозку. По-третє, пошкоджена плацента пов'язана з підвищеною проникністю плацентарного бар'єру, що дозволяє токсичним хімічним речовинам мати більший вплив на формуння нервової системи [3].

Отже, передчасні пологи $€$ основним фрактором ризику травм головного мозку, і оскільки передчасні пологи різко припиняють вплив на плід аллопрегнанолону, існує зв'язок між постачанням цього гормону і розвитком мозку.

\section{Список використаних джерел:}

1. Children's National Health System. (2019). Placental function linked to brain injuries associated with autism. Retrieved from

2. https://www.sciencedaily.com/releases/2019/04/190427104806.htm. [in English]

3. S., Sebaoui. (2019). Autism spectrum disorder risk linked to insufficient placental steroid. Retrieved from: https://www.eurekalert.org/pub_releases/2019-10/cnh-asd101719.php. [in English]

4. Liji, Thomas. (2019). Autism spectrum disorder could be triggered by low placental steroid levels. Retrieved from https://www.news-medical.net/news/20191021/Autism-spectrum-disorder-couldbe-triggered-by-low-placental-steroid-levels.aspx. [in English] 
DOI 10.36074/29.11.2019.v3.16

\section{ВИЗНАЧЕННЯ ФУНКЦІОНАЛЬНОГО СТАНУ КЛІТИН БУКАЛЬНОГО ЕПІТЕЛІЮ ПРАЦІВНИКІВ ВО «КАПРОЛАКТАМ» МЕТОДОМ ВНУТРІШНЬОКЛІТИННОГО ЕЛЕКТРОФОРЕЗУ}

\section{Сіренко Олена Віталіївна}

канд. мед. наук, доцент, доцент кафедри клінічної лабораторної діагностики Харківська медична академія післядипломної освіти

Кучеренко Ела Олексіївна канд. мед. наук, доцент, доцент кафедри клінічної лабораторної діагностики Харківська медична академія післядипломної освіти УКРАЇHA

Визначення діагностично значущих лабораторних маркерів порушення метаболічних процесів при дії хімічних патогенів $€$ однією з пріоритетних задач профрілактичної медицини [1,2]. Будь-яке відхилення динамічної рівноваги внутрішнього середовища, викликане дією агресивних фракторів або розвитком патологічних станів, призводить до зміни функціонального, а у подальшому - i структурного стану клітин організму [1]. Відомо, що електричні властивості клітинної мембрани та ядра багато у чому обумовлені їх структурою [2].

3 метою превентивної оцінки характеру впливу субтоксичних доз БКОС, синтезованих на основі гліколів, на цитоплазматичні мембрани та внутрішньоклітинний метаболізм було обстежено 82 працівника ВО «Капролактам».

Методи і матеріали: обробляли нативні клітини букального епітелію апаратників ВО «Капролактам» парами розчинів гальмівної, гідравлічної та охолоджувальних рідин у концентраціях $0,1 \% ; 0,05 \%$ і 0,001\%. У якості контролю була обстежена група працівників інженерно-технічної групи (ITP), букальний епітелій яких не піддавали дії парів органічних речовин. Препарати для дослідження готували шляхом взяття мазку з внутрішнього боку щоки 3 додаванням краплини 0,9\% розчину $\mathrm{NaCl}$, після чого реєстрували фонові показники і обробляли парами органічних сумішей з експозицією 1,5 та 24 години. Мікроелектрофорез ядер проводили у камері з електродами, що не окислюються, розташованими на відстані 20 мм, при напрузі 30 В і силі струму 0,1 А. До біоматеріалу додавали 0,5 мкл середовища для електрофорезу $(2,98$ мМ $\mathrm{CaCl}_{2}$ на 3,30 мМ фосфратному буфері, $\mathrm{pH}-7,0$, питома електропроводність - 0,239 $\left.\mathrm{Om}^{-1} / \mathrm{M}^{-1}\right)$, після чого реєстрували ЕНЯ. Основою методу $€$ використання здатності клітинних ядер формувати стабільне переважання негативного заряду нуклеїнових кислот над плюсовим зарядом кислих білків (гістонів) [3]. Отриманий фрактичний матеріал оброблено статистично з використанням критерія Стьюдента-Фішера.

Результати та обговорення: Результати дослідження, наведені у табл. 1, були представлені у вигляді діаграм, що дає змогу наочно оцінити різницю інтенсивності електронегативності ядер букального епітелію на вплив розчинів різної концентрації багатокомпонентних органічних сумішей. 
90 • Problèmes et perspectives d'introduction de la recherche scientifique innovante $\bullet$ Volume 3

Таблиця 1

Показники ЕНЯ букального епітелію працівників ВО «Капролактам» $(M \pm m), n=82$

\begin{tabular}{|c|c|c|c|c|}
\hline \multirow{3}{*}{$\begin{array}{l}\text { Речо- } \\
\text { вини }\end{array}$} & \multirow{3}{*}{$\begin{array}{l}\text { Експо- } \\
\text { зиція }\end{array}$} & \multicolumn{3}{|c|}{ Концентрація речовин (\%) } \\
\hline & & 0,1 & 0,05 & 0,001 \\
\hline & & \multicolumn{3}{|c|}{ Електронегативність } \\
\hline \multirow[t]{2}{*}{ OP - 40} & 1,5 & $28,700 \pm 1,1995^{\star}$ & $37,431 \pm 2,421^{*}$ & $42,300 \pm 2,445$ \\
\hline & 24 & $19,387 \pm 2,431^{*}$ & $35,128 \pm 1,442^{*}$ & $41,800 \pm 2,351$ \\
\hline \multirow[t]{2}{*}{ OP - 65} & 1,5 & $28,793 \pm 1,961^{*}$ & $36,100 \pm 1,798^{*}$ & $42,305 \pm 1,979$ \\
\hline & 24 & $20,417 \pm 2,410^{*}$ & $31,791 \pm 2,583^{*}$ & $44,521 \pm 2,112$ \\
\hline \multirow[t]{2}{*}{$\Gamma P$} & 1,5 & $25,371 \pm 2,412^{*}$ & $31,250 \pm 2,264^{*}$ & $40,912 \pm 2,086$ \\
\hline & 24 & $21,688 \pm 1,735^{*}$ & $29,572 \pm 1,685^{*}$ & $45,311 \pm 2,651$ \\
\hline \multirow{2}{*}{ ГдР } & 1,5 & $18,462 \pm 1,563^{*}$ & $38,226 \pm 2,516^{*}$ & $43,724 \pm 1,366$ \\
\hline & 24 & $22,400 \pm 1,813^{*}$ & $43,712 \pm 2,054$ & $46,843 \pm 2,916$ \\
\hline \multirow{2}{*}{$\begin{array}{l}\text { Конт- } \\
\text { роль, } \\
\text { ITP }\end{array}$} & 1,5 & \multicolumn{3}{|c|}{$45,300 \pm 2,032$} \\
\hline & 24 & \multicolumn{3}{|c|}{$44,000 \pm 2,488$} \\
\hline$\Phi \mathrm{\Phi H}$ & - & \multicolumn{3}{|c|}{$43,025 \pm 2,314$} \\
\hline
\end{tabular}

Примітка: * - різниця показників вірогідна $(p<0,05)$. [авторська розробка]

Встановлено, що найбільше зниження електропотенціалу ядер відбувалося внаслідок дії речовин у концентрації 0,1\%, а найменше - при впливі $0,001 \%$ парів розчинів органічних сумішей. Така динаміка змін показників дозволяє говорити про дозозалежність впливу речовин на функціональний стан клітин.

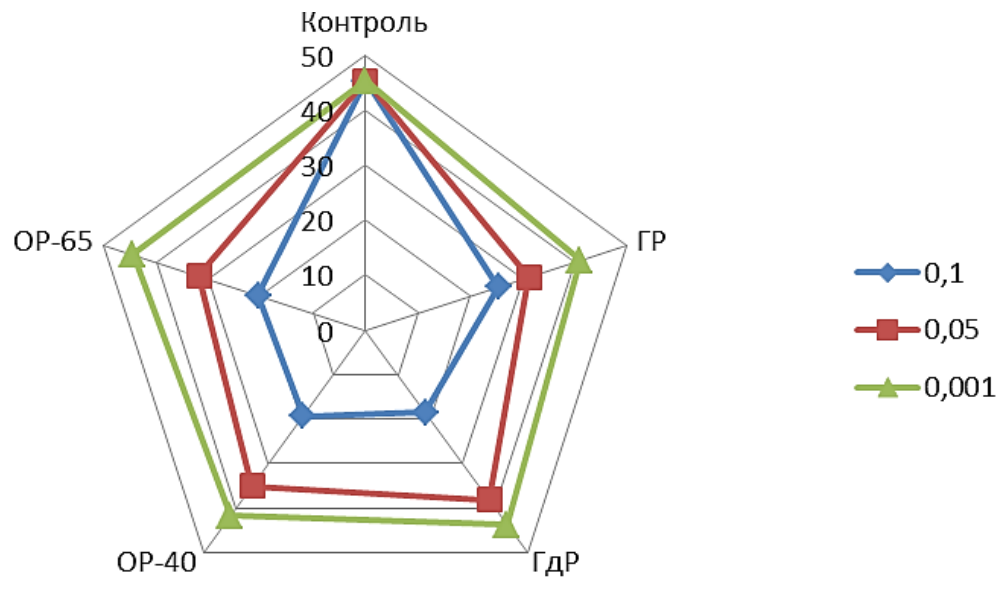

Рис. 1. Вплив БКОС на показники електронегативності ядер букального епітелію працівників ВО «Капролактам» при експозиції 1,5 години.

Пари органічних сумішей у концентраціях 0,1\% та 0,05\% вірогідно знижували ЕНЯ в усіх випадках: вплив ОР-40 обумовлював зниження ЕНЯ у 2,5 рази $(p<0,05)$ з експозицією 1,5 години та у 3,8 рази $(p<0,05)$ з експозицією 24 години, у той же час, 0,001\%-ний розчин БКОС не впливав на показники 
електронегативності ядер букального епітелію. Визначене вірогідне зниження ЕНЯ дозволяє непрямо оцінити вплив БКОС на внутрішньоклітинний метаболізм, у тому числі, пригнічення електричної активності нуклеїнових кислот ядра.

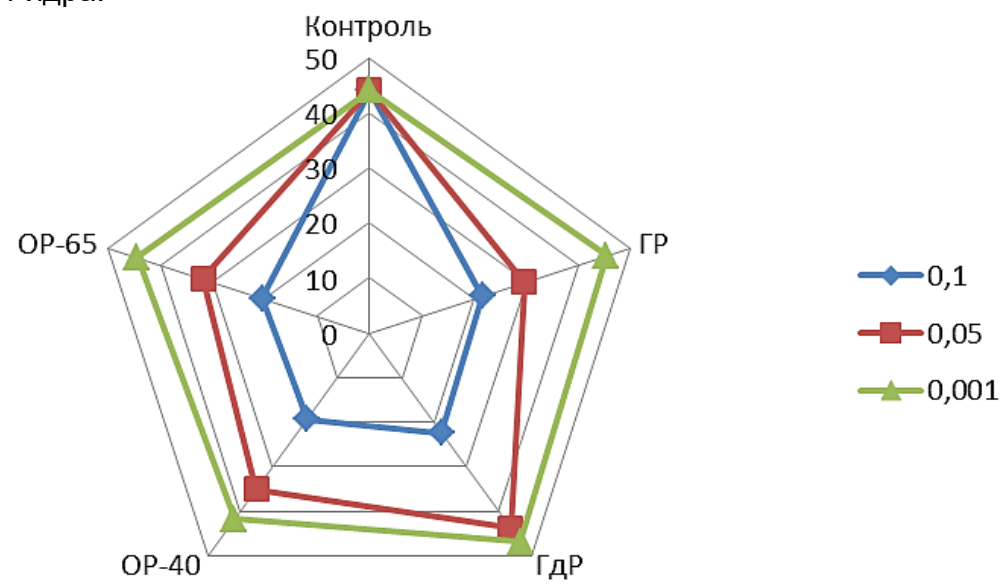

Рис. 2. Показники електронегативності ядер букального епітелію працівників ВО «Капролактам» при експозиції 24 години.

Результати ЕНЯ виявили первинні прояви зсувів у метаболічних процесах, які, можливо, обумовлені оксидативним стресом та відбуваються на молекулярному рівні, що підтверджує доцільність використання даного метода для обстеження великих контингентів населення, планових медичних оглядів працівників шкідливих виробництв у тому числі [4]. Дестабілізація цитоплазматичної мембрани, особливо ії гідрофобного шару, може стати пусковим моментом виникнення структурно-функціональних порушень, змін біоенергетики клітини, коливань ядерного електропотенціалу, що викликає розвиток стійких порушень гомеостазу у випадках зниження компенсаторних можливостей організму.

\section{Висновки:}

1. Пари багатокомпонентних органічних сумішей у концентраціях $0,1 \%$ та 0,05\% вірогідно знижували ЕНЯ букального епітелію робітників ВО «Капролактам». Найбільші зміни показників відзначали про дії OP-40, яка обумовлювала зниження ЕНЯ у 2,5 рази $(p<0,05)$ з експозицією 1,5 години та у 3,8 разів $(p<0,05)$ з експозицією 24 години. Визначене вірогідне зниження ЕНЯ дозволяє непрямо оцінити вплив БКОС на пригнічення електричної активності нуклеїнових кислот ядра.

2.Метод визначення електронегативності ядер букального епітелію $€$ інформативним, малоінвазивним, чутливим, його доцільно використовувати при обстеженні великих контингентів населення, що контактує зі шкідливими хімічними речовинами, для своєчасного виявлення метаболічних порушень. 


\section{Список використаних джерел:}

1. Markovič, T., Gobec, M. \& Gurwitz, D. et al. (2015). Characterization of human lymphoblastoid cell lines as a novel in vitro test system to predict the immunotoxicity of xenobiotics. Toxicologi.Lett. 233(1). 8-15. Вилучено 3 http://www.ncbi.nlm.nih.gov/pubmed/25542143.

2. Дейнека, С. Є. \& Проданчук, М. Г. (2009). Концепція використання методу культур клітин при оцінці засобів цитопротекції. Проблеми діагностики, просрілактики та лікування екзогенних та ендогенних інтоксикацій:матеріали науково-практичної конфреренції. 1314 жовтня 2009 р. Чернівці, Україна.

3. Шахбазов, В. Г., Григорьева, Н. Н. \& Колупаева, Т. В. (1996). Новый цито-биофизический показатель биологического возраста и физиологического состояния человека. Физиология человека, 6(22), 71-75.

4. Щербань, М. Г., М'ясоєдов, В. В. \& Шевченко, О. О. (2010). Методичні аспекти використання методології оцінки ризику здоров'ю населення при впливі факторів навколишнього середовища в Україні та Росії. Вісник ХНУ ім. В.Н.Каразіна, 898(19), 97-104.

DOI 10.36074/29.11.2019.v3.17

\section{ВПЛИВ НИЗЬКОЇ ТЕМПЕРАТУРИ НА ОРГАНІЗМ ДІТЕЙ}

\section{НАУКОВО-ДОСЛІДНА ГРУПА:}

Старусева Вікторія Вадимівна канд. мед. наук, доцент, доцент кафедри гігієни та екології №1 Харківський національний медичний університет

Катамадзе Русудан Нодаріївна
студент
Харківський національний медичний університет
Федоренко Ольга Валентинівна
студент
Харківський національний медичний університет
УКРАїНА

Актуальність. Наша сучасність характеризується винятковою тривожною ситуацією щодо зростання частоти алергійної патології. Актуальним завданням сучасної медицини $є$ виявлення впливу холоду на дітей. В даний час діти дуже рідко бувають на повітрі, мало займаються спортом, внаслідок чого, імунна система швидко виснажується і тому з кожним роком все більш дітей хворіють на холодову алергію.

Мета дослідження. Дати уявлення про те, чи може холод вплинути на дитину. Діти стискаються з багатьма фракторами ризику навколишнього середовища, які впливають на організм в цілому.

Матеріали і метод. Для визначення цього захворювання часто проводять провокаційний тест з кубиком льоду.

На зону передпліччя малюка кладуть обгорнутий в поліетилен крижаний кубик. Протягом десяти хвилин ми спостерігали за відповіддю організму. При 
сильній реакції симптоми хвороби проявляються вже через хвилину, в інших випадках - через 20 хвилин. Підтвердження алергії на холод - це сигнал батькам пройти додаткові обстеження для діагностування більш серйозних патологічних і інфекційних захворювань.

Результати. Алергія на холод проявляється у вигляді звичайної кропив'янки - численних плоско виступаючих «пухирців», які сильно сверблять, як при опіку кропивою. Висип може розташовуватися як на відкритих ділянках шкіри, які найбільше страждають від холоду, так і на всьому тілі. Також може виникнути холодовий дерматит. Для дерматиту характерно поява на шкірі рук і обличчя, що зудять темно-червоних плям, які через кілька днів починають лущиться, грубіють і покриваються скоринкою з тріщинами.

Висновок. Холодова алергія $є$ актуальною темою на сьогоднішній день, бо безліч дітей не захищенні від неї в холодний період року, тому для профілактики призначається без рецепту антигістамінний препарат. Також не варто забувати про крем, який утворюючи на шкірі захисну плівку, запобігає появи холодової алергії у дитини.

\title{
Список використаних джерел:
}

1. Михайленко, А. А. \& Базанов. Г. А. (2015). Алергія і алергічні захворювання. Медичне інформаційне агентство.

2. Онойко, Н. Ю. (2017). Алергія. Діагностика, профілактика і методи лікування. Москва: РДГУ.

3. Пігулевська, I. (2017). Алергія. Як ї̈ перемогти. Прості та ефрективні методи тримати алергію під контролем. М .: Центрполиграф.

\section{ГІГІЄНА РУК У МЕДИЧНИХ ЗАКЛАДАХ ЯК НЕСПЕЦИФІЧНА ПРОФІЛАКТИКА ІНФЕКЦІЙ}

\author{
Нечипоренко Єлизавета Андріївна \\ Харківський національний медичний університет \\ Науковий керівник: Сасіна О. С. \\ кандидат медичних наук, асистент кафредри гігієни та екології №1 \\ Харківський національний медичний університет
}

УKPAÏHA

Медичні заклади, зокрема лікарні та поліклініки є безбережним джерелом інфекцій. Переважна більшість інфекцій передається контактним та/або аліментарним шляхами. Саме руки знаходяться зазвичай у безпосередньому контакті з пацієнтами (при огляді, пальпації, маніпуляціях) та колегами.

Гігієна рук була визнана найважливішим засобом запобігання передачі інфекції, і великий акцент був зроблений на шляхи поліпшення дотримання гігієни рук медичними працівниками. Але слід зазначити, що гігієни рук мають дотримуватися усі люди, що будь-яким чином пов'язані з медичним закладом 
та безпосередньо перебувають в ньому, а саме пацієнти, медичний персонал, адміністрація та інші працівники закладу, люди, що навідуються до стаціонарних пацієнтів та студентство, що приходить на заняття або практику [2].

Для персоналу ще у 2007 році Всесвітньою організацією охорони здоров'я були розроблені такі рекомендації як підхід «Мої 5 моментів гігієни рук», що визначає ключові моменти, коли медичні працівники повинні виконувати гігієну рук. Цей підхід базується на дослідженнях, експериментах та великій доказовій базі. Він орієнтований як на захист пацієнта, так і на захист медичного працівника. Такий підхід рекомендує медичним працівникам виконувати гігієну рук у наступних випадках: перш ніж торкатися пацієнта, перед чистими/асептичними процедурами, після впливу або ризику впливу рідини на організм, після дотику до пацієнта і після дотику до оточення пацієнта [3].

Однак на практиці ці рекомендації не завжди виконуються сумлінно. Особливо у відділеннях невідкладної допомоги. Натовп у відділенні невідкладної допомоги зумовлений необхідністю оглянути велику кількість пацієнтів різної тяжкості станів в обмеженому фрізичному просторі. Але дуже важливо надаючи допомогу не зашкодити. Було проведено дослідження, де автори оцінили, чи пов'язана специфіка таких відділень зі зменшенням дотримання гігієни рук серед медичних працівників. Спостерігач оцінював дотримання гігієни рук у лікарів та медсестер відділення невідкладної допомоги протягом 22 місяців. За результатами цього дослідження дотримання гігієни рук склало 29\% (325 з 1116 людей). Миття рук за допомогою спиртовмісних антисептиків склало 66\%. Медсестри складали 68\% від персоналу, лікарі - 18\%, решта 14\% припадає на медичних працівників, які безпосередньо не надають медичної допомоги. Найчастіше виконувалися необхідні рекомендації щодо гігієни рук після контакту з пацієнтом або його оточенням (52\%) і лише $35 \%$ до контакту з ним [3].

Також проблемою $є$ невиконання необхідних заходів для чистоти рук серед студентства, що відвідують медичні заклади з метою освіти. Під час занять на клінічних кафедрах студенти виконують різні завдання та процедури для догляду за пацієнтами, що обумовлює широкий контакт з ними. Дослідження показали низьку відповідність серед медичних працівників. Загальне дотримання гігієни рук у групі учнів становила $83,5 \%$. Найвищий відсоток виконання необхідних процедур спостерігався після дотику до оточення пацієнта, після дотику до пацієнтів та після ризику впливу рідини на організм. Найнижча відповідність була зафіксована перед дотиком до пацієнтів або оточення пацієнта та перед чистими/асептичними процедурами. Це вказує на вищу стурбованість своїм здоров'ям та недбалим ставленням до здоров'я пацієнтів та оточення. Слід зазначити, що необхідно підвищувати не тільки сумлінність студентства, а й більш якісного нагляду та навчання з боку викладачів або керівників [1].

Проблема неякісного дотримання гігієни рук активно піднімається ВОЗ більше 10 років, але не було виявлено єдиного оптимального рішення. Однією із спроб є програма «Чистий догляд безпечніший догляд» ("Clean Care is Safer Care"), адаптацією якої є, наприклад, німецька кампанія «Чисті руки» ("Clean Hands Campaign"). Але дослідження, що були проведені з 2013 по 2015 рік 
визначили, що одним із сучасних способів боротьби з цією проблемою $є$ модель, що визначає ключові психологічні детермінанти відповідності. Тобто має в основі індивідуальний підхід, що стимулює людей самим слідкувати за собою. Ці детермінанти були оцінені серед медичних працівників у відділеннях за допомогою анкети. В опитуванні прийняли участь $71 \%$ лікарів та $63 \%$ медсестер. Також було проведено інтерв'ю голів відділень та старших медсестер (100\%). Опитаних було розподілено на дві групи: в одній було впроваджено різні індивідуальні методики підвищення відповідальності, а інша (контрольна група) відвідувала заняття за типом підвищення кваліфрікації. Результати порівняли через рік та два роки роботи. Дві групи не відрізнялися за базовим рівнем відповідності на початку дослідження $(54 \%$, і $55 \%$ контроль). Індивідуальні методики призвели до збільшення дотримання в кожному з двох наступних років (64\% і $70 \%$, відповідно), тоді як відповідність у контрольній групі зросла до 68\% наприкінці першого року дослідження, але впала до 64\% на другому. Отже індивідуальні підходи засновані на принципах поведінкової психології, призвели до більш стійкого збільшення дотримання правил гігієни рук, ніж навчальні заняття [4].

Отже, на сьогодні проблема недотримання обхідних заходів щодо гігієни рук залишається актуальною та стосується усіх учасників лікувального процесу. Найбільш ефективним методом вирішення цього питання $€$ індивідуальний підхід, направлений на підвищення відповідальності.

\section{Список використаних джерел:}

1. Korhonen, A., Vuori, A., Lukkari, A., Laitinen, A., Perälä, M. \& Koskela T. (2018). Increasing nursing students' knowledge of evidence-based hand-hygiene: A quasi-experimental study. Nurse Education in Practice. doi:10.1016/j.nepr.2018.12.009.

2. Landers, T., Abusalem, S., Coty, M. \& Bingham J. (2012). Patient-centered hand hygiene: The next step in infection prevention American. Journal of Infection Control, Vol. 40, Issue 4, S11S17.

3. Muller, M.P., Carter, E., Siddiqui, N., Larson, E. (2015). Hand Hygiene Compliance in an Emergency Department: The Effect of Crowding. Acad Emerg Med. 22(10):1218-21. doi: 10.1111/acem. 12754 .

4. Lengerke, T., Lutze, B., Krauth, C., Lange, K., Stahmeyer, J. T., \& Chaberny, I. F. (2017). Promoting Hand Hygiene Compliance. Deutsches Arzteblatt international, 114(3), 29-36. doi:10.3238/arztebl.2017.0029. 
DOI 10.36074/29.11.2019.v3.18

\title{
ГІГІЄНІЧНА ХАРАКТЕРИСТИКА УМОВ ПРАЦІ ЛИВАРНИХ ЦЕХІВ МАШИНОБУДІВЕЛЬНОГО ЗАВОДУ
}

\author{
НАУКОВО-ДОСЛІДНА ГРУПА: \\ Арзуманова Інеса Володимирівна \\ студентка III курсу III медичного факультету \\ Харківський національний медичний університет \\ Базян Аїда Арменівна \\ студентка III курсу III медичного фракультету \\ Харківський національний медичний університет \\ Науковий керівник: Косілова О.Ю. \\ кандидат медичних наук, асистент кафедри гігієни та екології №1 \\ Харківський національний медичний університет \\ УКРАÏHA
}

У ливарному виробництві всі процеси супроводжуються виділенням пилу, а також токсичних і дратівливих газів. При вибиванні і очищенні лиття виникають шум і вібрація. При спостереженні за плавкою металу і при заливці його у форми робочі піддаються впливу високих температур і променевої енергії. Все це справляє негативний вплив на здоров'я робітників, може викликати гострі та хронічні професійні отруєння та захворювання (наприклад, ливарну лихоманку).

Методом дослідження було визначення вібраційного рівня відповідно за ДСН 3.3.6.039-99 «Державні санітарні норми виробничої загальної та локальної вібрації». Рівні загальної вібрації вимірювалися на частотах 2,4 , 8 , 16, 21 і 63 Гц. Датчик кріпився на металевій пластині. Виміри проводилися в трьох взаємно перпендикулярних площинах х, в, г. Рівень загальної вібрації на підлозі в кабіні мостового крана на робочому місці машиніста крана обрубної ділянки не перевищував НДР. Клас шкідливості умов роботи 11 - допустимий [2; 3].

Рівні локальної вібрації вимірювалися на частотах 8, 16, 31, 63, 125, 250, 500 і 1000 Гц. Датчик розташовувався на адаптері, який кріпився жорстко до рукоятки віброінструменту. Вимірювання проводились також в трьох взаємно перпендикулярних площинах. Вимірювання в кожній осі проводилися 3 рази, а потім усереднювалися. На підставі даних вимірювань в октавних смугах частот розраховувався коректований по частоті рівень локальної та загальної вібрації Після цього розраховувався еквівалентний коректований рівень вібрації [1].

Результати досліджень показали, що значна кількість робочих продовжують працювати в умовах шкідливого впливу високих показників виробничої локальної вібрації (вибивальщики, формувальники, обрубщики). Ризик розвитку вібраційної патології залишається високим. В умовах особливостей технологічного процесу виготовлення виливків практично неможливе зниження еквівалентного рівня локальної вібрації до нормованих величин, тому виникає необхідність удосконалення питань експертизи 
працездатності при вібраційній хворобі. Розробка методик з дієвої організації диспансерного нагляду за працівниками може привести до часткового і навіть до повного регресу патологічних порушень і відповідного зниження кількісного показника при вібраційній патології.

\section{Список використаних джерел:}

1. Абракітов, В. (2013). Вібрація як виробнича шкідливість. Охорона праці, 6, 44-47.

2. Абракітов, В. (2014). Шум як шкідливий чинник виробництва. Охорона праці, 4, 56-59.

3. Боровик, І.Г., Шестаков, В.Г., Мельник, О.Г. \& Дрокіна, О.М. Стан професійної захворюваності на підприємствах машинобудування. XV з'їзд гігієністів України «Гігієнічна наука та практика: сучасні реалії» (с.73-75). 20-21 вересня 2012 р., Львів.

\section{ДОСЛІДЖЕННЯ ФАКТОРІВ, ЩО ВПЛИВАЮТЬ НА ПСИХІЧНЕ ЗДОРОВ'Я СТУДЕНТСТВА МЕДИЧНИХ ЗАКЛАДІВ ПІД ЧАС ЗДОБУТТЯ ВИЩОї ОСВІТИ}

НАУКОВО-ДОСЛІДНИЦЬКА ГРУПА:

Кателевська Наталія Миколаївна канд. мед. наук, доцент кафедри гігієни та екології №1 Харківський національний медичний університет

Дяченко Ірина Олексіївна канд. мед. наук., доцент кафедри гігієни та екології №1 Харківський національний медичний університет

Каднай Олексій Сергійович здобувач вищої освіти 3 курсу I медичного факультету Харківський національний медичний університет

УKPAÏHA

Актуальність. Студентство медичних закладів завжди зіштовхувалося не лише з великою кількістю інформації для засвоєння, але й з тяжким моральним навантаженням. Уже починаючи 3 студентських років медики починають вигорати. Нерідко можна зустріти випадки, коли студенти не можуть витримати навантаження та йдуть з університетів або їх відраховують за неуспішність у навчанні. Але з навчальних закладів мають випускатися відносно здорові, особливо психічно, майбутні лікарі. Тож вивчення та розробка способів попередження емоційного перенавантаження $€$ надзвичайно актуальними питаннями психогігієни та психопрофрілактики.

Мета: виявити найбільш поширені та вагомі фактори, що впливають на психіку студентства вищих медичних шкіл.

Матеріали й методи. Було розроблене анонімне опитування, що включало в себе ситуаційні питання із шкалою частоти, з якою такі випадки зустрічаються (де 0 - ніколи, а 10 - постійно) та шкалою рівня емоційної відповіді на задану ситуацію (де -10 - дуже негативно, 0 - все одно, 10 - дуже позитивно). 
Опитування пройшли 100 осіб, які навчаються у Харківському національному медичному університеті (100) та на медичному фракультеті Харківського національного університету ім. Каразіна (22). Вік анкетованих від 18 до 24 років. Були використані методи статистичного аналізу та анкетування.

Результати. Серед 20 описаних фракторів було виявлено 5 основних: велика кількість інформації (91,8\%), некомфортне ставлення викладачів (63,9\%), необхідність зіштовхнутися з трагедіями та проблемами інших людей $(59,8 \%)$, мала кількість вільного часу $(59,8 \%)$, система надання медичних послуг та ставлення пацієнтів (59\%). Результати дослідження було розраховано у відсотковому відношенні. Реакцією на такі подразники стала емоційна нестабільність у $89,3 \%$ опитаних, безсоння у $66,4 \%$, напади злості у $53,3 \%$, плач та знесилення у $36 \%$, діагностована депресія у $7,4 \%$. Інтенсивність негативної реакції для перших трьох фракторів виявилася майже однаковою. Серед інших чинників слід виділити некомфортне проживання (26,2\%), сімейні проблеми $(40,2 \%)$, стосунки в групі або на курсі $(22,1 \%)$, конкурентне ставлення лікарів до студентства (12,3\%). Також необхідно звернути увагу на фрактори, що викликають позитивні емоції. У $100 \%$ випадків це відпочинок (вихідні, канікули). Також за шкалою емоційної відповіді набрали від 6 до 10 особисті стосунки, віддача роботі викладачів та викладачок, дружні стосунки в групі, читання, перегляд фрільмів/серіалів, участь у наукових конференціях та розважальних заходах. 12,3\% студентства відвідували або відвідують психолога та зазначають позитивний вплив терапії.

Висновки. Отже, головними факторами, що впливають на психіку студентства медичних закладів $є$ здебільшого соціальні, а саме великий обсяг інформації для засвоєння, ставлення викладачів, переживання трагедій пацієнтів та пацієнток.

\section{Список використаних джерел:}

1. Бардов, В. Г. (2009). Гігієна та екологія. Вінниця: Нова книга, 591-605.

2. Прокопенко, А. В. (2014). Психогігієна: навчальний посібник. Острог: Видавництво Національного університету «Острозька академія».

\section{ЕМОЦІЙНЕ ВИГОРАННЯ У ЛІКАРІВ-ОНКОЛОГІВ}

Братчук Кирило Вадимович

здобувач освіти медичного факультету Харківський національний медичний університет

Оксененко Юлія Романівна здобувач освіти медичного факультету Харківський національний медичний університет

Науковий керівник: Древаль Мар'яна Василівна асистент кафредри гігієни та екології №1 Харківський національний медичний університет УКPAÏHA 
Актуальність. У сучасному світі все більш актуальною проблемою стають онкологічні захворювання. Щорічно діагностують все більше нових випадків онкології у людей. У багатьох цей термін асоціюється з приреченістю, болем, стражданням. Безпомічність і важкі страждання перед цим захворюванням вимушують пацієнта шукати психологічну підтримку. В цьому випадку лікарю - онкологу необхідно виконувати не тільки свої профільні обов'язки, але й не характерні йому функції психолога та психотерапевта. $€$ зрозумілим, що робота 3 такими групами хворих $\epsilon$ додатковим психотравмуючим фактором, тому постійно вимагає від лікаря високого рівня компетенції, особливої професіональної відповідальності і вміння протистояти постійній психоемоціональному напруженню. У зв'язку з цими фракторами лікарі - онкологи найбільш схильні до синдрому емоційного вигорання.

Мета дослідження - вивчення синдрому емоційного вигорання у онкологів, визначення етапів професійної діяльності лікарів, на яких з'являються ознаки цього синдрому.

Матеріали і методи дослідження. У дослідженні взяло участь 40 лікарів - онкологів віком від 45 до 60 років з мінімальним стажем роботи 20 років. Вони пройшли анкетування на основі тесту К. Маслач та С. Джексона, адаптоване і спрямоване на визначення рівня емоційного вигорання саме онкологів, яке містило 22 питання. Результати оцінювалися за трьома показниками: емоційне виснаження, деперсоналізація та редукція професіональних досягнень, які мають 3 рівня вигорання - низький, середній та високий.

Результати та їх обговорення. При вивченні результатів опитування виявилося, що в категорії емоційне виснаження 8 осіб (20\%) мали високий рівень виснаження, 10 осіб (25\%) - середній рівень виснаження, а 22 особи (55\%) не мали виражених ознак емоційного виснаження. Емоційне виснаження проявляється в зниженні емоційного тонусу, байдужістю, нездатністю відчувати сильні емоції, як позитивні, так і негативні, втрати інтересу i позитивних почуттів до оточуючих. У категорії деперсоналізації 6 осіб (15\%) мали високий рівень деперсоналізації, 4 особи (10\%) мали середній рівень деперсоналізації, 30 осіб $(75 \%)$ не мали чітких ознак деперсоналізації. Деперсоналізація проявляється в емоційному відстороненні і байдужості, формальному виконанні професійних обов'язків без особистого співпереживання, а в окремих випадках - в дратівливості, негативізмі і цинічному ставленні до колег і пацієнтів. У категорії редукції професіональних досягнень 4 особи (10\%) мали високий показник редукції, 4 особи (10\%) мали середній показник редукції, 32 особи (80\%) мали низький показник редукції. Редукція профресійних досягнень проявляється в негативному оцінюванні себе, результатів своєї праці і можливостей для професійного розвитку. Високе значення цього показника відображає тенденцію до негативної оцінки своєї компетентності i продуктивності i, як наслідок, зниження профресійної мотивації, наростання негативізму стосовно службових обов'язків.

Висновок. Отже, отримані результати показують, що головним фрактором при формуванні синдрому емоційного вигорання $є$ стаж роботи. Основні ознаки вигорання починають формуватися після 25 років роботи. Основним його проявом $є$ емоційне виснаження. Для попередження виникнення такого стану у лікарів необхідно проводити додаткові семінари з саморегуляції, 
підвищення стресовитривалості та контроля за власним психологічним станом.

\title{
Список використаних джерел:
}

1. Левин, Т. \& Киссан, В. Д. (2006). Психоонкология: состояние на 2006 г. Психолог. расстройства в общей мед., (3), 59-64.

2. Freudenberger, H. \& North, G. (1992). Burn-out bci Frcucn (2-nd ed.). Frankfurt.

3. Gibson, F., McGrath, A. \& Reid, N. Occupational stress in social work. British J. of Social Work, 19(1), 118.

4. Grahun, J. (1996). Cull A ct job stress and satisfaction among palliative physicians. Palliant Med, (10), 185-194.

5. Grunfeld, E., Whelan, T. J., Zitzelsberger, L., Willan, A. R., Montesanto, B., \& Evans, W. K. (2000). Cancer care workers in Ontario: prevalence of burnout, job stress and job satisfaction. CMAJ : Canadian Medical Association journal = journal de l'Association medicale canadienne, 163(2), 166-169.

\section{ЕФЕКТИВНІСТЬ ВИКОРИСТАННЯ МОДИФІКОВАНИХ АДЕНО ТА ГЕРПЕС ВІРУСІВ ДЛЯ ТЕАРПІЇ ОНКОЛОГІЧНИХ ЗАХВОРЮВАНЬ}

\author{
Александрова Катерина Володимирівна \\ Харківський національний медичний університет \\ Журавльова Поліна Володимирівна \\ Харківський національний медичний університет \\ Науковий керівник: Гаврилов А.Ю. \\ асистент кафедри онкології \\ Харківський національний медичний університет
}

УKPÄ̈HA

Актуальность. Наразі за даними ВООЗ рак $є$ другою з основних причин смерті в світі; так, в 2018 р від цього захворювання померли 9,6 млн чоловік [1]. Онкологічні захворювання стають причиною практично кожної шостої смерті в світі [2], тому вітально важливим $€$ пошук нових більш ефективних методів терапії онкологічних недугів. В останній час велику цікавість в лікуванні онкологічних хвороб представляють онколітичні віруси (ОВ), які $є$ вірусними агентами, що розмножуються переважно в неопластичних клітинах і ендотелії, викликаючи імунну відповідь в організмі. Модифріковані ОВ - це в нормі патогенні для людини віруси з трансформованим апаратом клітинної інвазії і блоку противірусного захисту або підвищеної селективності до клітин 3 певними мембранними рецепторами, в зв'язку з чим вони виявляють свою патогенність в пухлинних клітинах з дефектами захисту. 
Метою нашого дослідження є вивчення можливості застосування ОВ в складі комбінованої терапії онкохворих, з огляду на особливості механізму взаємодії адено та герпес вірусів з клітинами організму.

Матеріали та методи. Спираючись на проведений аналіз даних літератури про найбільш актуальні напрями в лікуванні онкологічних захворювань, обробку та ретроспективний метааналіз емпірічніх даних стосовно дослідження впливу на загальну виживаність пацієнтів віротерапевтичних препаратів, була розглянута можливість застосування в ході лікування пацієнтів перспективних онколітичних вірусів, таких як аденовіруси та герпесвіруси, і вироблена оптимальна концепція комбінованої терапії онкохворих.

Результати. Найбільш актуальні на сьогодні ОВ: модифікований герпесвірус T-VEC, схвалений в якості препарату для лікування пізніх стадій меланоми, і аденовірус Н101 - для лікування поширених пухлин голови, шиї і стравоходу. Talimogene laherparepvec $(\mathrm{T}-\mathrm{Vec})$ - це перший препарат групи ОВ, який довів ефрективність в III фразі клінічних випробувань і схвалений для використання в Європі і США [1]. Вірус побудований на базі ВПГ-1 з мутацією в двох генах: делеція альфа-47 i гамма-34.5. У неопластичній клітині порушений механізм блоку синтезу білка, тому мутантний по гамма-34.5-вірус може в ній реплікуватися. Вимкнення альфа-47 посилює експресію МHC1 в клітинах пухлини і протипухлинну імунну відповідь, а також запускають механізми клітинної смерті. [1, 2]. В Європі показаннями до застосування ТVEC $€$ наявність неоперабельної меланоми у дорослих. Як онколітичних агентів 3 групи аденовірусів використовують віруси 5-го серотипу. Найбільш відомий представник онколітичних аденовірусів - Н101, який дозволений для використання в Китаї. Підвищення тропності вірусу до пухлинних клітин досягається шляхом в інсерції RGD-4C капсидних білків, які пов'язуються 3 рецепторами, присутніми тільки на поверхні ракової клітини [1, 2].

Висновки: Основною задачею віротерапії $€$ підвищення селективності по відношенню до пухлинних клітин, з метою посилення ефректу ОВ і зниження системної токсичності. Дискутабельним залишається питання відносно ефективності застосування онковірусів 3 огляду на обмежену кількість проведених досліджень, тому дана тема потребує поглибленого вивчення механізмів дії та проведення додаткових клінічних випробувань 3 метою подальшої комбінації онколітичних вірусів 3 іншими імунотерапевтичними засобами.

\section{Список використаних джерел:}

1. Lundstrom, K. (2017). Latest trends in cancer therapy applying viral vectors. Future Virol, (12), 667-684. [in English]

2. Kaufman, H.L., Kohlhapp, F.J., Zloza, A. (2015). Oncolytic viruses: a new class of immunotherapy drugs. Nat Rev Drug Discov, (14), 642-662. [in English] 


\title{
НАПРЯМИ ДЕРЖАВНОГО РЕГУЛЮВАННЯ РИНКУ МЕДИЧНИХ ПОСЛУГ В УКРАЇНІ
}

\author{
Барзилович Анастасія Дмитрівна \\ кандидат медичних наук, директор \\ МЦ «КіндерКлінік» \\ УКРАÏHA
}

У сучасних умовах, надання якісних медичних послуг населенню виступає елементом підвищення якості життя громадян та загального соціального рівня держави. Система регулювання медичних послуг $\epsilon$ складною та розгалуженою. До ії̈ складу входять суб'єкти регулювання (органи законодавчої та виконавчої влади, місцеві органі влади, органі місцевого самоврядування), об'єкти регулювання, цілі та завдання, методи, фооми, інструменти регулювання та наявне фрінансово-економічне, законодавче, інформаційне забезпечення. До методів (засобів) впливу на суб'єктів ринку медичних послуг можемо відносити процеси ліцензування та акредитації чи державний контроль за дотриманням нормативно-визначених стандартів надання медичних послуг. Основними суб'єктами державного регулювання ринку медичних послуг $є$ Президент України, Верховна Рада України та Міністерство охорони здоров'я України а також інші органи виконавчої влади. Перелік суб'єктів регулювання їх фрункцій та повноваження наведено у таблиці 1.

Таблиця 1

Функції та повноваження ключових суб'єктів державного регулювання ринку медичних послуг згідно нормативно-правових актів

\begin{tabular}{|c|c|c|}
\hline Суб’єкт & $\begin{array}{l}\text { Нормативно- } \\
\text { правовий акт }\end{array}$ & Функції та повноваження у сфері медицини \\
\hline $\begin{array}{l}\text { Президент } \\
\text { України }\end{array}$ & $\begin{array}{l}\text { Конституція } \\
\text { України }\end{array}$ & $\begin{array}{l}\text { Несе особисту відповідальність за реалізацію } \\
\text { державної політики охорони здоров'я [1] }\end{array}$ \\
\hline $\begin{array}{l}\text { Верховна Рада } \\
\text { України }\end{array}$ & $\begin{array}{c}\text { Закон України } \\
\text { «Основи } \\
\text { законодавства } \\
\text { України про } \\
\text { охорону здоров'я» }\end{array}$ & $\begin{array}{l}\text { Верховна Ради України являє собою основу державної } \\
\text { політики охорони здоров'я «шляхом закріплення } \\
\text { конституційних і законодавчих засад охорони } \\
\text { здоров'я» [2] }\end{array}$ \\
\hline \multirow[t]{2}{*}{$\begin{array}{l}\text { Кабінет Міністрів } \\
\text { України }\end{array}$} & $\begin{array}{c}\text { Закон України } \\
\text { «Основи } \\
\text { законодавства } \\
\text { України про } \\
\text { охорону здоров'я» }\end{array}$ & $\begin{array}{l}\text { Організовує розробку та здійснення державних } \\
\text { цільових програм, створює економічні, правові та } \\
\text { організаційні механізми, що стимулюють ефективну } \\
\text { діяльність в сфері охорони здоров'я, забезпечує } \\
\text { розвиток мережі закладів охорони здоров'я, укладає } \\
\text { міжурядові угоди і координує міжнародне } \\
\text { співробітництво з питань охорони здоров'я, а також в } \\
\text { межах своєї компетенції здійснює інші повноваження, } \\
\text { покладені на органи виконавчої влади в сфері охорони } \\
\text { здоров'я [2]. }\end{array}$ \\
\hline & $\begin{array}{c}\text { Закон України } \\
\text { «Про забезпе- } \\
\text { чення санітарного } \\
\text { й епідемічного }\end{array}$ & $\begin{array}{l}\text { Затверджує Положення про державний санітарно- } \\
\text { епідеміологічний нагляд в України [3] }\end{array}$ \\
\hline
\end{tabular}


Продовження табл. 1

\begin{tabular}{|c|c|c|}
\hline Суб'єкт & $\begin{array}{l}\text { Нормативно- } \\
\text { правовий акт }\end{array}$ & Функції та повноваження у сфері медицини \\
\hline \multirow{3}{*}{$\begin{array}{l}\text { Кабінет Міністрів } \\
\text { України }\end{array}$} & $\begin{array}{c}\text { благополуччя } \\
\text { населення» }\end{array}$ & \\
\hline & $\begin{array}{c}\text { Закон України } \\
\text { «Про державні } \\
\text { фінансові гарантії } \\
\text { медичного } \\
\text { обслуговування } \\
\text { населення» } \\
\end{array}$ & $\begin{array}{l}\text { Затверджує Порядок функціонування електронної } \\
\text { системи охорони здоров'я. } 32018 \text { року запроваджує } \\
\text { реалізацію державних гарантій медичного } \\
\text { обслуговування населення за програмою медичних } \\
\text { гарантій для первинної медичної допомоги у порядку, } \\
\text { встановленому Кабінетом Міністрів України [4] }\end{array}$ \\
\hline & $\begin{array}{c}\text { Закон України } \\
\text { «Про екстрену } \\
\text { медичну } \\
\text { допомогу» }\end{array}$ & $\begin{array}{l}\text { Затверджує обсяги підготовки, перепідготовки та } \\
\text { підвищення кваліфікації за державним замовленням } \\
\text { медичних працівників для потреб системи екстреної } \\
\text { медичної допомоги. Забезпечення екстреною } \\
\text { медичною допомогою іноземців та осіб без } \\
\text { громадянства, які тимчасово перебувають на території } \\
\text { України, а також фрізичних осіб, які взяті під варту або } \\
\text { яким призначено покарання у виді позбавлення волі [5] }\end{array}$ \\
\hline \multirow[t]{2}{*}{$\begin{array}{l}\text { Міністерство } \\
\text { охорони здоров'я } \\
\text { України }\end{array}$} & $\begin{array}{l}\text { Постанова КМУ від } \\
25 \text { березня } 2015 \text { р. } \\
\text { № } 267 \text { «Про } \\
\text { затвердження } \\
\text { Положення про } \\
\text { Міністерство } \\
\text { охорони здоров’я } \\
\text { України» }\end{array}$ & $\begin{array}{l}\text { Забезпечує формування та реалізація державної } \\
\text { політики у сфері охорони здоров'я, визначає } \\
\text { пріоритетні напрями розвитку системи екстреної } \\
\text { медичної допомоги; забезпечує в межах повноважень, } \\
\text { передбачених законом, додержання закладами } \\
\text { охорони здоров'я, підприємствами, установами та } \\
\text { організаціями права громадян на охорону здоров'я та } \\
\text { прав пацієнта; визначає єдині кваліфікаційні вимоги до } \\
\text { медичних та інших працівників закладів охорони } \\
\text { здоров'я системи екстреної медичної допомоги та їх } \\
\text { структурних одиниць; затверджує галузеві стандарти у } \\
\text { сфері охорони здоров'я, зокрема клінічні протоколи і } \\
\text { стандарти, здійснює контроль за їх дотриманням; } \\
\text { критерії та стандарти державної акредитації закладів } \\
\text { охорони здоров'я; єдині кваліфрікаційні вимоги до осіб, } \\
\text { які провадять певні види медичної та фрармацевтичної } \\
\text { діяльності, у тому числі господарську діяльність; } \\
\text { здійснює:- ліцензування господарської діяльності з } \\
\text { медичної практики; видає спеціальні дозволи фізичним } \\
\text { особам - підприємцям на зайняття народною } \\
\text { медициною (цілительством) [6]; }\end{array}$ \\
\hline & $\begin{array}{c}\text { Закон України } \\
\text { «Про державні } \\
\text { фінансові гарантії } \\
\text { медичного } \\
\text { обслуговування } \\
\text { населення» }\end{array}$ & $\begin{array}{l}\text { Здійснює державний контроль за наданням медичної } \\
\text { допомоги в санаторно-курортних закладах у сфері } \\
\text { санітарного та епідемічного благополуччя населення, } \\
\text { які мають право у встановленому законодавчими } \\
\text { актами порядку зупиняти діяльність цих закладів через } \\
\text { порушення законодавства про охорону здоров'я або } \\
\text { законних прав та інтересів громадян [4]. }\end{array}$ \\
\hline
\end{tabular}

Серед проблем, що негативно впливають на розвиток медичних послуг та які потрібно вирішити, насамперед через провідних суб'єктів регулювання, можемо виділити такі: високу реальну ринкову вартість медичних послуг, що не відповідає купівельні спроможності більшості громадян, незабезпеченість гарантованого рівня якості надання медичних послуг, збитковість діяльності державних та муніципальних закладів надання медичних послуг, низький рівень ефективності системи надання медичної допомоги в територіальних одиницях (районах, селах, селищах), недостатність заходів із профрілактичної медицини (яка застосовується провідними державами світу), недоліки у 
проведенні перепідготовки та підвищення кваліфікації вищого та середнього медичного персоналу тощо.

В умовах рефоормвання ринку медичних послуг регулююча діяльність суб'єктів має бути спрямована на забезпечення соціальної доступності медичних послуг у тому числі для жителів віддалених та гірських районів, жителів територій прилеглих до зони Операції об'єднаних сил (ООС), забезпечення якісної та своєчасної допомоги учасникам ООС, стимулювання беззбитковості та економічної ефективності послуг, децентралізації управління закладами охорони здоров'я, контролю та нагляду за якістю медичних послуг, як у державному секторі, так і недержавними закладами застосування нових (інноваційних технологій), організації надання медичних послуг, електронізації обслуговування пацієнтів та внутрішньої системи управління закладів, підвищення кваліфікації медичного персоналу за кордоном та реалізації нових підходів до навчання, забезпечення профрілактики захворювань та ефективності первинної допомоги.

За результатами досліджень І.Л. Сазонця та І.Я. Зими отриманих на підставі проведеного опитування пацієнтів щодо питань реформування соціальної системи управління охороною здоров'я в Україні у 2018 році, встановлено, що до питань, які потребують оперативного вирішення, можна віднести: підтримку закладів охорони здоров'я з боку міжнародних організацій; поширення діяльності міжнародних організацій на території України; удосконалення фрінансової інфраструктури на ринку фінансових послуг, що дасть поштовх до розвитку недержавних комерційних форм охорони здоров'я; сприяння збільшенню матеріальних ресурсів населення; розвиток можливостей спеціалізованого лікування в стаціонарі; підвищення санітарної культури населення; оптимізація мережі установ охорони здоров'я; вдосконалення діяльності управління фізичною культурою і спортом на регіональному рівні [7].

Отже, аналіз результатів дослідження доводить, що в умовах реформування нормативно-правова база потребує оновлення та вдосконалення, а сама система надання медичних послуг перефрорматування, підвищення якості, доступності, забезпечення фрінансової спроможності суб'єктів, застосування нових технологій у лікуванні та управлінні, підвищення значимості профрілактичної медицини.

\section{Список використаних джерел:}

1. Конституція України (редакція від 01.09.2016 р.). Верховна Рада України. Харків: Право.

2. Основи законодавства України про охорону здоров'я (Закон України), № 2801-ХІІ від 19.11.1992 р. Вилучено з http://zakon3.rada.gov.ua/laws/show/2801-12/page.

3. Про забезпечення санітарного й епідемічного благополуччя населення (Закон України), № 4004-ХІІ від 24.02.1994 р. Вилучено з https://zakon.rada.gov.ua/laws/show/4004-12.

4. Про державні фінансові гарантії медичного обслуговування населення (Закон України), № 2168-VIII від 19.10.2017 р. Вилучено з http://zakon2.rada.gov.ua/laws/show/2168-19.

5. ро екстрену медичну допомогу (Закон України), № 5081-VI. від 05.07.2012р. Вилучено з https://zakon.rada.gov.ua/laws/show/5081-17.

6. Про затвердження Положення про Міністерство охорони здоров'я України (Постанова КМУ), № 267 від 25.03.2015 р. Вилучено з https://zakon.rada.gov.ua/laws/show/267-2015$\% \mathrm{DO} \% \mathrm{BF}$. 
7. Сазонець, І. Л. \& Зима, І. Я. (2018). Дослідження проблеми транссрормації державної системи охорони здоров'я та діяльності соціальних інститутів. Інвестиції: практика та досвід, (21), 109-113. DOI: 10.32702/2306-6814.2018.21.109.

DOI 10.36074/29.11.2019.v3.19

\section{КЛІНІКО-АНАМНЕСТИЧНІ ФАКТОРИ РИЗИКУ УРАЖЕННЯ НИРОК У ДІТЕЙ, ХВОРИХ НА ІG-А ВАСКУЛІТ}

НАУКОВО-ДОСЛІДНА ГРУПА:

Грищенко Дмитро Олександрович

здобувач вищої освіти II медичного фракультету Харківський національний медичний університет

Гірка Дмитро Едуардович

здобувач вищої освіти II медичного факультету Харківський національний медичний університет

Шевченко Данило Юрійович

здобувач вищої освіти II медичного факультету Харківський національний медичний університет

Яворович Марія Вадимівна асистент кафредри педіатрії №2 Харківський національний медичний університет УКРӒ̈̈А

Актуальність. Ig-А васкуліт визначається як васкуліт, який вражає дрібні судини (капіляри, венули або артеріоли), з подальшим відкладенням в їх стінці імунних комплексів переважно IgA підкласу 1 [1, 2]. До патологічного процесу залучаються шкіра, шлунково-кишковий тракт, часто спостерігається артрит. У 40-50\% пацієнтів розвивається ураження нирок у вигляді IgA-нефриту, який зазвичай протікає безсимптомно і тому вимагає активного скринінгу $[3,4]$. Встановлено, що пошкодження нирок $є$ головним фактором, детермінуючим результат захворювання. Ig-А васкуліт все частіше ідентифрікується, як основна причина хронічної ниркової недостатності серед дитячого населення [5]. Наразі, вкрай важливо виявлення провокуючих чинників розвитку IgAнесриту.

Мета. Визначення клініко-анамнестичних фракторів ризику розвитку IgAнефриту

Матеріали і методи. До дослідження увійшло 38 дітей віком від 4 до 18 років з діагнозом Ig-А васкуліт. Хворі поділено на наступні групи: 1 група пацієнти 3 lg-А васкулітом без пошкодження нирок $(n=29)$ та 2 група - діти із $\lg A$-нефритом (n=9). Ig-А васкуліт було діагностовано за критеріями, визначеними в 2012 році на міжнародній конференції в Chapel Hill за участю провідних фахівців в ревматології, нефрології, імунології та морфології. [6]. Основними методами дослідження стало ретельне вивчення скарг, анамнезу життя, анамнезу захворювання, даних об'єктивного дослідження, клініко- 
лабораторних та інструментальних даних. Під час збору скарг та анамнезу захворювання намагались з'ясувати з чим пов'язане його виникнення. Вивчення анамнестичних даних хворих включало відомості про перенесені захворювання, дані про спадкові й сімейні захворювання, інформацію про алергійний статус. Особлива увага приділялася супутнім соматичним захворюванням та наявності хронічних вогнищ інфекції. IgA-нефрит діагностували за наявності гематурії та / або протеїнурії протягом першого місяця від встановлення діагнозу васкуліту.

Отримані дані були піддані статистичній обробці 3 використанням статистичних програм „EXCELL FOR WINDOWS” та „STATISTICA 7.0. FOR WINDOWS". Порівняння номінальних даних проводилось за допомогою точного критерію Фішера з оцінкою рівнів значущості відмінностей. Отримане значення точного критерію Фішера р більше 0,05 свідчило про відсутність статистично значущих відмінностей, значення р менше 0,05 - про їхню наявність. В якості кількісної міри ефекту при порівнянні відносних показників нами використовувався показник відношення шансів (OR) з розрахунком меж 95\% довірчого інтервалу $(95 \% \mathrm{Cl})$.

Результати та їх обговорення. Аналізуючи скарги дітей з'ясовано, що у $12(31,5 \%)$ дітей відмічалося підвищення температури тіла до субфебрильних та фебрильних цифр. 38 (100\%) дітей скаржились на наявність геморагічного висипу, $30(78,9 \%)$ дітей пред'являли скарги на біль та набряк суглобів, 13 $(34,2 \%)$ дітей відмічали скарги на болі в животі. Порівняльний аналіз наведених скарг в групах не виявив статистично значущих відмінностей $(p>0,05)$.

Відомо, що тригерними факторами в розвитку lg-А васкуліту провідну роль грають алергічні реакції та перенесені напередодні гострі інфекційні захворювання верхніх дихальних шляхів. У 21 (55,2\%) хворого основної групи найбільшу частоту факторів, які передували розвитку захворювання, склали гострі респіраторні захворювання. Відмінності показників серед обстежуваних груп, оцінені за допомогою точного критерію Фішера, були статистично значущі ( $<<0,05$, OR 9,8, 95\% Cl 1,08-89,2). Зафріксовано, що майже у кожного 3 хворого основної групи розвитку хвороби сприяли ті чи інші алергійні процеси $(36,8 \%)$, проте достовірних відмінностей не виявлено $(p>0,05)$.

Проведене ретельне опрацювання даних алергологічного анамнезу. Встановлено, що $21(55,2 \%)$ хворий основної групи мали алергічну настроєність організму. Однак, аналіз чотирьохпольної таблиці за цією ознакою статистичних відмінностей не виявив $(p>0,05)$. Часті гострі респіраторні захворювання спостерігали у 15 (39,4\%) дітей, наявність хронічних вогнищ інфекцій ЛОР-органів виявлено у $14(36,8 \%)$ дітей. Відмінності показників за цими двома ознаками статистично значущі $(p<0,05$; OR 9,1, 95\% Cl 1,5-53,9; OR 5,2, 95\% Cl 1,05-26,1, відповідно).

Висновки. Аналіз клініко-анамнестичних даних дітей $3 \mathrm{lg}-\mathrm{A}$ васкулітом вказує на високо достовірні шанси розвитку IgA-нефриту у дітей, які в анамнезі мають наявність хронічних вогнищ інфекції ЛОР-органів і часто хворіють на протязі року. Також вірогідність зростає у дітей, етіологічним фактором розвитку захворювання у котрих, стало саме перенесення гострого інфекційного захворювання верхніх дихальних шляхів. 


\title{
Список використаних джерел:
}

1. Kiryluk, K., Moldoveanu, Z., Sanders, J. T., Eison, T. M., Suzuki, H., Julian, B. A., ... Wyatt, R. J. (2011). Aberrant glycosylation of $\lg A 1$ is inherited in both pediatric $\lg A$ nephropathy and HenochSchönlein purpura nephritis. Kidney international, 80(1), 79-87. DOI: 10.1038/ki.2011.16.

2. Oni, L., \& Sampath, S. (2019). Childhood IgA Vasculitis (Henoch Schonlein Purpura)-Advances and Knowledge Gaps. Frontiers in pediatrics, 7, 257. DOI: 10.3389/fped.2019.00257.

3. Jauhola O, Ronkainen J, Koskimies O, Ala-Houhala M, Arikoski P, ... Holtta T, (2010). Clinical course of extrarenal symptoms in Henoch-Schonlein purpura: a 6-month prospective study. Arch Dis Child, (95), 871-876. DOI: 10.1136/adc.2009.167874.

4. Huang, X., Wu, X., Le, W., Hao, Y., Wu, J., Zeng, C., ... Tang, Z. (2018). Renal Prognosis and Related Risk Factors for Henoch-Schönlein Purpura Nephritis: A Chinese Adult Patient Cohort. Scientific reports, 8(1), 5585. DOI: 10.1038/s41598-018-23638-2.

5. Yan-Nan Guo, Zheng Wang \& Jing Lu (2013). The relationship between children kidney diseases and adult ESRD_an epidemiological investigation of 700 cases. Renal Failure, 35(10), 13531357, DOI: 10.3109/0886022X.2013.828262.

6. Jennette, J. C., Falk, R. J., Bacon, P. A., Basu, N. , Cid, M. C., Ferrario, F. , ... Watts, R. A. (2013). 2012 Revised International Chapel Hill Consensus Conference Nomenclature of Vasculitides. Arthritis \& Rheumatism, (65), 1-11. DOI: 10.1002/art.37715.

\section{МИКРОБИОМ И РАК: РАЗВИТИЕ И ЛЕЧЕНИЕ}

\begin{abstract}
Плотникова Мария Михайловна
студент первого медицинского факультета Днепропетровская медицинская академия МОЗ Украины

Линник Вячеслав Николаевич

студент первого медицинского фракультета Днепропетровская медицинская академия МОЗ Украины

Научный руководитель: Шарун Алеся Витальевна канд. мед. наук, доцент, доцент кафедры микробиологии, вирусологии, иммунологии и эпидемиологии Днепропетровская медицинская академия МОЗ Украины
\end{abstract} УКРАИНА

На сегодня доказано, что человеческий организм только на $10 \%$ состоит из собственно клеток, 90\% - это бактериальные клетки нормальной микрофлоры, которая была названа микробиотой. Эти клетки хорошо организованы, активно взаимодействуют между собой, имеют свой собственный метагеном, в 150 раз превышающий по объему человеческий, проявляют коллективную метаболическую активность, а некоторые исследователи даже наделяют микробиоту собственным интеллектом. Микробные колонии человеческого организма, объединенные в многоклеточные ассоциации, формируют самый большой орган нашего тела или даже некую биосоциальную систему, способную оказывать влияние на весь организм. 
Примерно 20\% всех случаев рака имеют инфекционную причину. Косвенным доказательством роли бактериальной клетки в развитии злокачественной опухоли является тот факт, что рак чаще развивается в органах с интенсивным эпителиально-микробным взаимодействием (например, толстая кишка, легкие, печень) и намного реже в тех органах, клетки которого не контактируют с микробиотой (головной мозг, суставы) [1].

Патогенез заболеваний и одновременно способы их лечения прямо или косвенно связаны с фрерментативной и биохимической активностью микробиома и его влияние на организм человека. Выделены белки и метаболиты микробов, которые постоянно взаимодействуют с геномом человека, изменяя его. Геном человека содержит около 22000 генов. Микробы наделяют наш организм еще 8 млн. генов. Белки и метаболиты, образующиеся в результате жизнедеятельности микробиома, проникают в ткани человека. Взаимодействие между белками и человека и белками микробного сообщества влияет на весь спектр метаболических процессов в организме человека.

Канцерогенез - многофракторный процесс, связанный с генетическими и экологическими изменениями. Среди микроорганизмов, обитающих на Земле, лишь немногие были определены международным агентством по изучению рака (International Agency for Research on Cancer, IARC) как канцерогенные агенты: пока к ним относят Helicobacter pylori, вирус гепатита В и С, ВИЧ-1, вирусы папилломы человека, вирус Эпштейн-Барра, герпеса человека тип 8, Т-клеточный лимфотропный вирус человека тип 1, Opisthorchis viverrini, Clonorchis sinensis и Schistosoma haematobium и некоторые другие [2]. Люди колонизированы триллионами микробов, но только немногие из них связывают с развитием рака. Микробиота вместе с другими фракторами риска приводит к коллективной ответственности за процесс канцерогенеза.

Понимание фрундаментальных механизмов эпителиально-микробного взаимодействия, а также изучение роли патогенной и комменсальной микрофрлоры в развитии воспаления при ранних и поздних стадиях канцерогенеза может изменить парадигму скрининга и диагностики, а также выявить новые мишени таргетной терапии рака.

Далее мы рассмотрим различные виды рака, и влияние на их развитие микробиоты человека.

\section{Микробиом и рак желудка.}

Рак желудка считается, связанным с воспалением. Колонизация слизистой желудка $H$. pylori является фрактором риска воспалительных заболеваний этого локуса. Онкопротеины являются факторами вирулентности $H$. pylori, повышенное накопление воспалительных цитокинов обнаруживается в желудке, инфицированных. Вследствие этого стимулируются различные типы иммунных клеток (лимфоциты, периферические мононуклеарные клетки, эозинофрилы, макрофраги, нейтрофилы, тучные клетки и дендритные клетки). Активность онкогенных путей активируется инфекцией, обусловленной $H$. pylori. Генерация фракторов, связанных с воспалением, может приводить к инактивированию генов опухолевых супрессоров (например, индуцированная мутация Р53). Методами на основе полимеразной цепной реакции было показано, что больные раком желудка отличаются очень разнообразным составом микробиоты: при незначительном количестве одних микроорганизмов (Porphyromonas, Neisseria, Prevotella pallens, Streptococcus 
sinensis), одновременное повышение других (Lactobacillus coleohominis, Klebsiella pneumoniae, Acinetobacter baumannii и Lachnospiraceae spp) [3].

\section{Микробиом и колоректальный рак.}

Микроорганизмы В кишечнике имеют тесную связь с развитием колоректального рака, воздействуя на механизмы обмена человека и регулируя физиологическую функцию кишечника. В основе связи микробима кишечника и развития колоректального рака лежит выработка токсичных метаболитов путем ферментации ингредиентов пищи. Бактерии кишечной микробиоты оказывают индуцирующее действие. Бактерии запускают экспрессию генов хемокинов путем стимуляции ТПР (толл-подобных рецепторов), рецепторов, расположенных на поверхности опухолевых клеток и способных распознавать компоненты бактериальных клеток. Доказать эту гипотезу помогло использование очищенных агонистов ТПР, которые привели к повышению уровня хемокинов. Это показывает, что клетки КРР являются основным источником хемокинов, и раскрывает важную роль микробиоты в индукции иммунного ответа. В предыдущих исследованиях говорилось о связи между сверхэкспрессией хемокиновых рецепторов в опухолевой ткани (преимущественно CCL5, CXCL9 и CXCL10) и повышением выживаемости пациентов. Результаты данного исследования показывают высокий уровень экспрессии хемокиновых рецепторов (CCR5 и CXCR3) в другой ткани, инфильтрированной лимфоцитами, что говорит о благоприятном прогнозе болезни. Вместе с тем опухолевые клетки вызывают сверхэкспрессию генов хемокинов [4]. Эта сверхэкспрессия не была обнаружена in vitro, следовательно, какой-то компонент микроокружения выполняет ключевую функцию в среде in vivo. Обнаруженные механизмы открывают возможности для разработки инновационных методов лечения на основе модуляции микробиоты, направленных на стимуляцию лимфоцитарной инфильтрации опухолевой ткани и, как следствие, повышение выживаемости пациентов.

\section{Микробиота и рак поджелудочной железы.}

Протоковая аденокарцинома поджелудочной железы (ПАПЖ) является самой распространенной формой рака поджелудочной железы. Чтобы улучшить статистику, необходимо включить микробиомы кишечника и поджелудочной железы в глобальную стратегию лечения ПАПЖ. Выявлено, что бактериальная нагрузка у пациентов с ПАПЖ намного больше, чем в образцах тканей поджелудочной железы здоровых людей. Известно, что некоторые бактерии поджелудочной железы, в частности Bifidobacterium pseudolongum, инактивируют Т-клетки (путем связывания с ТПР, толлподобными рецепторами) и тем самым защищают опухоли от действия иммунной системы организма [5]. Исследования показали, что устранение некоторых вредных бактерий замедлило рост опухоли поджелудочной железы, обратило вспять подавление иммунитета и активировало PD1(белок иммунной системы) [6]. Таким образом, воздействие на бактерии кишечника и поджелудочной железы в диагностике, лечении и профилактике представляется одним из наиболее перспективных подходов к лечению ПАПЖ.

Микробиом кишечника и рак печени.

Истощение кишечных бактерий с помощью смеси антибиотиков снижало частоту развития и размеры опухолей и уменьшали количество метастазов. 
$110 \bullet$ Problèmes et perspectives d'introduction de la recherche scientifique innovante $\bullet$ Volume 3

Доказано, что введение антибиотиков увеличивает в печени количество естественных Т-киллеров - обладающих цитотоксичностью против опухолевых клеток. Накопление естественных Т-киллеров в печени приводит к повышению синтеза белка CXCL16 в эндотелиоцитах - клетках, выстилающих внутреннюю стенку сосудов. Обнаружено, что желчные кислоты также могут контролировать экспрессию белка CXCL16. Введение желчных кислот сказывается на количестве Т-киллеров и, тем самым, на скорости прогрессирования рака печени [7].

Желчные кислоты образуются в печени, они расщепляют жиры, поступающие с пищей. Один из представителей микрофлоры кишечника C.scindens - участвует в метаболизме жирных кислот. Продукты этого взаимодействия являются сигналом, регулирующим синтез белка CXCL16 в эндотелиоцитах сосудов печени, который влияет на количество натуральных Т-киллеров и скорость роста опухоли.

\section{Микробиом легких.}

Экологические детерминанты формирования микробиома легких распространение, выведение, условия размножения - все они значительно изменяются при заболеваниях легких. У здоровых людей преобладают бактерии Bacteroidetes, a c патологией доминируют микроорганизмы Proteobacteria, большое разнообразие грамотрицательных бактерий. Была

обнаружена двусторонняя связь между микробиомами кишечника и легкого, что говорит о том, что изменения в одном локусе могут повлиять на другой. Также ученые вывели такую гипотезу: воспаление легких, связанное с аденокарциномой легких и спровоцированное местной микробиотой, может способствовать активации локального иммунного ответа, вызванного специфической категорией Т-клеток под названием үठ-Т-клетки. Эти клетки обильно представлены в опухолевых тканях, и считается, что они дифференцируются в үठ-Т-клетки, продуцирующие провоспалительные медиаторы (ИЛ-22 и амфирегулин), которые вызывают инфильтрацию активизирующими опухоль нейтрофилами [8]. Легочные инфекции усугубляют этот вредоносный процесс за счет поддержания локального дисбиоза. Таким образом, инактивация этих Т-клеток либо их медиаторов представляет собой потенциальную терапевтическую мишень в будущем.

\section{Заключение.}

В настоящее время предпринимаются попытки воздействовать на течение некоторых острых и хронических заболеваний с помощью оптимизации состава кишечной микрофлоры. Для этого используют диетические мероприятия, пробиотики (молочнокислые лактобациллы, бифидобактерии, энтерококки или некоторые штаммы E. coli), пребиотики (соединения, поддерживающие пролиферацию полезных лактобацилл и бифидобактерий), симбиотики, антибиотики и даже трансплантацию микробиоты другого человека. Целью этих мероприятий является восстановление эубиоза кишечной флоры.

Подобные терапевтические стратегии обсуждаются также в контексте профилактики и лечения рака.

Модификация кишечной бактериальной микробиоты сможет заблокировать ранние стадии канцерогенеза путем уменьшения воспаления, патологического метаболизма, образования генотоксинов, влияя на пролиферативные и антиапоптотические сигналы. 
Возможно, что профилактическим противоопухолевым эффектом могут обладать и некоторые антибиотики, селективно подавляющие генотоксинпродуцирующие бактерии. Что касается ранней диагностики рака, то уже сегодня не вызывает сомнений, что обнаружение бактерий высокого канцерогенного риска (их генотоксинов или метаболитов) сможет в ближайшее время вывести программу скрининга онкологических заболеваний на новый уровень.

\section{Список используемых источников:}

1. Kovalev, A.A. (2015). Zdorov'e Ukrainy. TV «Urologiya. Nefrologiya. Andrologiya», (1), 38-39.

2. Bagirov, N. S., Petuhov, I. N., Dmitriev, N. V. \& Grigor'evskaya, Z. V. Mikrobiom i rak: est' li svyaz.

3. Changting, Meng, Chunmei, Bai, Thomas, D. Brown, Leroy, E. Hood \& Qiang, Tian. (2018). Human Gut Microbiota and Gastrointestinal Cancer. Genomics Proteomics Bioinformatics, 16 (1), 33-49. doi: 10.1016 / j.gpb.2017.06.002.

4. Cremonesi, E. (2018). Gut microbiota modulate T cell trafficking into human colorectal cancer.

5. Pushalkar, S. (2018). The Pancreatic Cancer Microbiome Promotes Oncogenesis by Induction of Innate and Adaptive Immune Suppression. Cancer Discov, 8(4), 403-416

6. Researchers say. Retrrieved from https://www.deccanchronicle.com/lifestyle/health-andwellbeing/220318/researchers-say-certain-bacteria-promotes-pancreatic-cancer.html

7. Stat'ya, C. Ma. Gut microbiome-mediated bile acid metabolism regulates liver cancer via NKT cells. Science.

8. Jin, C. Lagoudas, G., Zhao, C. (2019). Commensal Microbiota Promote Lung Cancer Development. $\gamma \delta T$ Cells. Cell, S0092-8674(18)31654-4.

\section{ПРОБЛЕМА ЗАБРУДНЕННЯ НАВКОЛИШНЬОГО СЕРЕДОВИЩА ПЛАСТИКОМ}

НАУКОВО-ДОСЛІДНА ГРУПА:

Алієв Рашад Адем огли

здобувач вищої освіти медичного університету Харківський Національний Медичний Університет

Камчатна Валерія Артемівна

здобувач вищої освіти медичного університету Харківський Національний Медичний Університет

Шенгелія Тамарі Ємзарівна

здобувач вищої освіти медичного університету Харківський Національний Медичний Університет

Науковий керівник: Дрокіна О.М. асистент кафедри гігієни та екології №1 Харківський Національний Медичний Університет УКРАÏHA

На сьогодні однією з найважливіших тем для обговорення є екологічне питання, а саме проблема утилізації пластику. Актуальним є те, що досі ще не 
встановлений точний термін його розкладання, але шкоду для навколишнього середовища він наносить колосальну. У даний момент єдиним розв'язанням цієї проблеми є повторне використання пластику.

Культура сортування відходів ще зовсім не на високому рівні в Україні, але з кожним роком все більше громадян починають більш відповідально ставитися до цього. Метою дослідження є звернути увагу суспільства на проблему повторного використовування пластику, інформування о можливих наслідках його нераціонального використання. Найбільш поширений вид пластику - пляшки, які виготовляються із поліетилентерефталату, 3 них зазвичай і починають сортування. На виготовлення однієї літрової пляшки виходить 250 мл нафтти і 3 літри води. Подальший шлях використання пляшки залежить від споживача, а як показує практика на повторне перероблювання вона доходить дуже рідко. Пластикові відходи перш за все потрапляють у ріки, або безпосередньо у море, де піддаються впливу ультрафіолетового випромінювання і розкладаються на мікроскопічні частинки - «нардли». Крім цього, у ріки можуть потрапляти дрібні полімерні фрагменти, що являють собою синтетичні волокна тканин, що змиваються під час прання. Їх дрібні субміліметрові розміри не піддаються впливу фрільтрів стокових вод, тому вони врешті також потрапляють в океан та становляться вимушеною їжею морських жителів.

В океані пластик розкладається на протязі року, але не повністю, тому у результаті цього процесу утворюються токсичні речовини - бісфенол А та полістирол, які негативно впливають на життєдіяльність мешканців океану. Крім цього, мікрочастинки полістиролу і нардли є найбільш розповсюдженим видом пластикового забруднення, разом 3 поліетиленовими плівками, контейнерами та поліетиленовими пакетами складають більшу частину океанічного сміття [1].

Розмір частинок - менше 5 мм, тому вони активно поглинаються планктоном, який є основною їжею для морських тварин.

Мікропластік надає не тільки механічне, але і хімічний вплив, оскільки плаваючі у воді забруднюючі речовини, що потрапляють в море з суші, зазвичай пристають до його поверхні.

Отже, проблема забруднення навколишнього середовища пластиком стоїть дуже гостро. Удосконалення й впровадження пластмасових виробів у $\mathrm{XX}$ столітті повністю перетворили життя й дали поштовх до розвитку багатьох галузей, включаючи медицину [2]. Але речовини, що звільняються при розкладі пластмаси впливають на різні системи організму, перш за все репродуктивну. Це означає - наслідки цього винаходу можуть дуже дорого коштувати здоров'ю людей. Для запобігання цього слід, в першу чергу, не допускати потрапляння пластикових відходів у ріки, моря та океани [2]. Україна поки тільки на початку свого шляху до повноцінного розвитку культури сортування відходів. I активні громади, які займаються екологічними проблемами, є рушійною силою цього процесу.

\section{Список використаних джерел:}

1. Martins, A. \& Guilhermino. L. (2018). Transgenerational effects and recovery of microplastics exposure in model populations of the freshwater cladoceran Daphnia magna Straus. 
ScienceDirect.

2. Parker, L. (2019). The world's plastic pollution crisis explained. National Geographic. Retrieved from https://www.nationalgeographic.com/environment/habitats/plastic-pollution/

3. Jia, L., Evans. S. (2019). Motivating actions to mitigate plastic pollution // nature communications. Retrieved from https://www.nature.com/articles/s41467-019-12666-9

\section{ПРОБЛЕМИ ВИКОРИСТАННЯ 3D-ПРИНТИНГУ У ЛІКУВАННІ ХІРУРГІЧНИХ ХВОРИХ}

НАУКОВО-ДОСЛІДНА ГРУПА:

Кателевська Наталія Миколаївна канд. мед. наук, доцент кафедри гігієни та екології №1 Харківський національний медичний університет

Дяченко Ірина Олексіївна канд. мед. наук., доцент кафедри гігієни та екології №1 Харківський національний медичний університет

Пелих Іван Миколайович

здобувач вищої освіти I медичного фракультету Харківський національний медичний університет

УКPAÏHA

Все більшій кількості людей потрібна пересадка органів. Згідно статистичних даних в Україні - 10000 осіб стоять в черзі на пересадку. Приблизно 3000 потрібна трансплантація нирки, 1500 - печінки, та 1000 осіб потребує донорського серця.

Декілька років тому проблему заміни органа вирішували шляхом трансплантації. Органи отримували від донорів. Людина отримувала шанс на щасливе життя. Часто траплялися випадки відторгнення та відмирання пересаджених органів, що завдавало ще більшої шкоди пацієнту. Наразі $€$ технологія я дозволяє запобігти ці помилки [1-3].

Вирощування органів - біоінженерна технологія, яка займається створення повноцінно цілих та життєздатних органів, які в подальшому можна замітити в організмі людини. Механізм цієї технології проходить в декілька етапів. Основні етапи це забір клітин, їхній розвиток, та імплантація органу до організму [4].

$€$ дуже багато технологічних методів, різниця яких пов'язана: за типом первинних клітин(з яких буде вирощуватися орган або структура), місцем вирощування клітин, масштабами та конструкцією потрібного органу. Вирощують органи за допомогою біореакторів, 3D принтерів а також в організмі тварин [5, 6].

Було проведено опитування 100 лікарів-хірургів Харківської обласної лікарні аби вияснити які основні проблеми використання технології 3Dпринтингу в українській трансплантології. Результати виявились такими: $5 \%$ - 
не чули про дану технологію, 15\% - вважає основною проблемою ціну даної технології, $25 \%$ - відсутність достатньо глибоких знань в цій галузі аби передбачити побічні ефекти та більше всього майже 55\% - вважають головною перешкодою відсутність кваліфрікованих кадрів для проведення цих операцій.

Основною перешкодою для проведення операцій 3 використанням технології 3D-принтингу полягає у відсутності кваліфікованих кадрів. Дуже великий ефект мали закордонні стажування задля обміну досвідом, а також створення відповідних медичних центрів де будуть розвивати цю технологію.

\title{
Список використаних джерел:
}

1. Григор'єв, Ю. І., Григор'єв, В. Ю. \& Істоміна, Л. Б. (2016). Правові аспекти проведення деяких видів біомедичних і клінічних експериментів. Вісник нових медичних технологій, 8(3), 7982.

2. Козлов, С. П. (2017). Основні досягнення в трансплантології. Трансплантологія і штучні органи, (4), 3.

3. Мур, Ф. (2010). І Історія пересадок органів. Москва: Світ.

4. Попова, Л. М. (2012). Етичні проблеми, що виникають при діагностиці смерті мозку. Анестезіологія та реаніматологія, (5-6), 69-72.

5. Bir, V. J., Ramos, T. L. \& Danovich, G. V. (2016). Evaluation of living renal donors - a current practice of UNOS transplant centers. Transplantation, (60), 322-327.

6. Chapman, J. R. \& New, B. (2015). Transplantation. In J.Chapmen, M.Deierhoi, C.Wight (Eds.). Organ and tissue donation for transplantation (pp. 1-19). London.

\section{РАЗРАБОТКИ В ЛЕЧЕНИИ БОЛЕЗНИ ПАРКИНСОНА ПУТЕМ ИНГИБИРОВАНИЯ LRRK2}

\author{
Кудрявых Полина Кирилловна \\ соискатель высшего образования медицинского фракультета \\ Харьковский национальный медицинский университет
}

УКРАИНА

Вступление: Болезнь Паркинсона (БП) это нейродегенеративное заболевание, которое стоит вторым по частоте встречаемости среди деструктивных заболеваний ЦНС после болезни Альцгеймера. Но на сегодняшний день это заболевание не излечимо. Существует только симптоматическое лечение, которое лишь замедляет дегенеративный процесс. Поиск действительных причин развития данного заболевания, а также этиотропного лечения - один из важных вопросов современной медицины.

Цель работы: Обзор литературы с целью анализа эфффективности такого перспективного метода лечения БП как использование препаратов ингибирующих LRRK 2.

Болезнь Паркинсона относят к спорадическим заболеваниям, но к ее развитию также могут привести генетические мутации. В норме, двигательная 
функция обеспечивается дофаминергическими нейронами. Прежде всего, за это отвечает черная субстанция ЦНС. Пресинаптические везикулы могут рециркулировать, но в определенный момент они должны поддаться утилизации. Нарушение этого процесса может возникать при мутациях в гене, отвечающего за белок alpha-synuclein (SNCA).Он находится в мембране везикул и отвечает за их отправку в аутофраголизосомы. Мутации приводят к нарушению утилизации везикул, высвобождению дофамина в терминаль аксона и нейротоксического действия свободных радикалов. Основным источником свободных радикалов являются митохондрии. Эти органеллы играют важную роль в развитии БП. За распознавание «старых» митохондрий аутофраголизосомами отвечают белки PINK и PRKN. Мутация в соответствующих генах ведет к нарушению утилизации митохондрий и к высвобождению дополнительных свободных радикалов, которые нарушают деградацию мутировавшего SNCA в убиквитин-зависимом протеасомном протеолизе. Важным участником всего процесса является белок LRRK2 (dardarin). Мутация в G2019S-LRRK2 ведет к повышению фосфорилирования SNCA, нарушению его деградации в протеасоме и образованию его олигомеров, которые обладают нейротоксичностью. Выявление мутаций в гене LRRK2 и ингибирование его функций может привести к излечению БП [1].

Ученые из университета Алабамы в Бирмингеме провели эксперимент на крысах с использованием ингибитора киназы LRRK 2 Pfizer LRRK2 (PF06447475). В мозг мыши было введено систему доставки вируса, экспрессирующую SNCA человека. Через 4 недели наблюдалось снижение нейродегенерации и нейровоспаления [2].

Учеными из университета Питтсбурга этот ингибитор использовался в другом эксперименте, с участием пестицида ротенона, который вызывал окислительный стресс у животных, а также наблюдалось 10-кратное увеличение активности LRRK 2 в дофаминергических нейронах. Анализ измерял фоссфорилирование Ser 1292,как маркера активности LRRK 2. В этом эксперименте также наблюдалось снижение активности этого гена. Важным дополнением являлось то, что в этом исследовании была доказана схожая активность LRRK 2 у людей с БП, но без мутации. К этому также может приводить нарушения функций лизосом и митохондрий, вызванных окислительным стрессом. Потому ингибиторы дардарина могут быть эфффективны не только при наследственных формах БП, но и при спорадических. [3].

В 2019 году в журнале «Cell research» было опубликовано исследование об эфффекте 5'-дезоксиаденозилкобаламина - одной из форм витамина В12 на активность LRRK2. По результатам наблюдений, 5'дезоксиаденозилкобаламин в культивируемых клетках и тканях мозга уменьшал развитие нейротоксического эффректа [4].

Вывод: Важно понимать, что ингибирование дардарина у людей может иметь побочные эфффекты, которые не исследовались в вышеуказанных экспериментах. LRRK 2 также имеет массу других функций. Предполагают, что он принимает участие в стабилизации микротрубочек, вместе с SNCA участвует в эндоцитозе синаптических везикул, регуляции сборки $F$ - актина.[5] Возможно, при ингибировании LRRK 2 другие функции также могут нарушаться. Но эксперименты по определению терапевтической дозы 
ингибитора уже проводятся, а эффеетивность такой методики для лечения БП будет гораздо выше того, которое используется сейчас.

\section{Список используемых источников:}

1. Bourdenx, M., Bezard, E., Dehay, B. (2014). Lysosomes and a-synuclein form a dangerous duet leading to neuronal cell death. Retrieved from ttps://www.frontiersin.org/articles/10.3389/fnana.2014.00083/full [in English]

2. Silva, P. (2015). Pfizer's Inhibitor Drug Able to Reduce Neurodegeneration in Parkinson's Disease Animal Models. Retrieved from https://parkinsonsnewstoday.com/2015/07/08/pfizers-inhibitordrug-able-reduce-neurodegeneration-parkinsons-disease-animal-models/ [in English]

3. Talan, J.. (2018). In the Pipeline-Parkinson's Disease Genetics Wild-Type LRRK2 Is Implicated in PD Patients Without Family History of Disease. Retrieved from https://journals.Iww.com/neurotodayonline/Pages/articleviewer. aspx?year=2018\&issue $=10040 \&$ article $=00020 \&$ type=Fulltext [in English]

4. University of the Basque Country. (2019). Vitamin B12 is identified as the inhibitor of a key enzyme in hereditary Parkinson's disease. ScienceDaily. Retrieved from www.sciencedaily.com/releases/2019/04/190404124818.htm [in English]

5. Пчелина, С.Н, Емельянов, А.К. \& Усенко Т.С. (2014). Молекулярные основы болезни Паркинсона, обусловленной мутациями в гене Irrk2. Изъято из http://molecbio.ru/downloads/mbm48/MBM48_1_0003.pdf.

\section{РОЛЬ ОСНОВНИХ ФАКТОРІВ ВІРУЛЕНТНОСТІ HELICOBACTER PYLORI У ВИНИКНЕННI РАКУ ШЛУНКА}

Гордієнко Поліна Олексіївна

здобувач вищої освіти медичного факультету Харківський національний медичний університет

Піонова Олена Миколаївна канд. мед. наук, асистент кафедри пропедевтики внутрішньої медицини №2 та медсестринства Харківський національний медичний університет УКРӒ̈НА

Введення. У 2018 році рак шлунка був п'ятим за розповсюдженістю злоякісним новоутворенням у світі та третім за причиною смерті [1]. Розвиток цього процесу пов'язують з колонізацією Helicobacter pylori (H. pylori), яка була виявлена у $80 \%$ хворих на рак шлунка [2]. Helicobacter pylori - це грам негативна мікроаерофрільна бактерія, яка мешкає у шлунку людини та тварин. За даними досліджень Н. pylori колонізує шлунок біля 50\% населення світу [3]. Саме з факторами вірулентності H. pylori, які вона синтезує, у більшості випадків пов'язують розвиток пухлинних процесів у шлунку, які виникають внаслідок порушення регуляції внутрішньоклітинних сигнальних механізмів: порушення балансу проліферації клітин та їх запрограмованою загибеллю. Одними з найбільш вірулентних фракторів $є$ цитотоксин-ассоційованийген А 
(Cag A), вакуалізуючий цитотоксин A (Vac A) та ліпополісахарид (LPS), які відіграють провідну роль у виникненні раку шлунка [4].

Мета роботи. Вивчення теоретичних аспектів впливу Helicobacter pylori на розвиток раку шлунка за допомогою фракторів вірулентності.

Виклад матеріалу. Розвиток раку шлунка у більшості випадків має досить стереотипний сценарій. У пацієнтів, хворих на хронічний поверхневий гастрит, розвивається атрофрія слизової оболонки шлунка, яка характеризується локальною втратою парієнтальних клітин. Цей процес у ряді випадків займає десятиліття. Згодом втрата парієнтальних клітин призводить до зменшення секреції соляної кислоти, i, як наслідок, до підвищення внутрішньо просвітного $\mathrm{pH}$, а також зниження вироблення соматостатину, і результатом цього $€$ зниження секреції гастрина. Дія гастрину на слизову оболонку шлунка характеризується стимулюванням секреції соляної кислоти парієнтальними клітинами та збільшення проліферації шлункового епітелію у зоні стовбурових клітин, що призводить до підвищення оновлення клітин епітелію слизової оболонки шлунка. У частини пацієнтів, у яких було виявлено атрофрію слизової оболонки шлунка спостерігається метаплазія епітелію 3 ентерізацією, внаслідок заміни оксинитивних залоз на CDX2 (гомеобокс 2 каудального типу), які сприяють утворенню епітелію, які за своєю будовою схожі на ентеральні крипти. Метаплазія з ентеризацією призводить у 20 \% пацієнтів до дисплазії слизової оболонки шлунка, а саме розвиток епітеліальної дисплазії шлунка підвищує вірогідність розвитку раку шлунка в 10 разів [2]. Н. pylori впливає на розвиток канцерогенного процесу за допомогою факторів вірулентності, до яких відносять цитотоксин-ассоційований ген A (Cag A), вакуалізуючий цитотоксин A (Vac A) та ліпополісахарид (LPS).

Ген Cag A кодує секреторную систему IV типу, яка за своєю структурою нагадує шприц. Цей ген активує сигнальні білки клітини-господаря, призводячи до активування онкогену, а також індукує процес гіперметилювання пухлинних генів-супресорів. Проникнення Cag А до епітеліальних клітин слизової шлунка призводять до патологічної проліфрерації клітин епітелію шлунка та запалення, зменшення апоптозу, можуть бути причинами канцерогенезу [4; 5].

Другим найбільш широко вивченим фактором вірулентності H. pylori $\epsilon$ Vac А. Саме роль цього фактору було доведено у руйнуванні моношару епітелію слизової оболонки шлунка, що є причиною підвищення проникності мембрани епітеліальної клітини до канцерогенів. Також він впливає на утворення мембранних каналів, викликає руйнування мембрани мітохондрій, що призводить до вивільнення з них цитохромів та подальшого руйнування клітини. [4;6].

Важливим компонентом клітинної стінки грамнегативних бактерій, зокрема H. pylori, є ліпополісахарид (ЛПС), який складається з ліпіду $A$, основоного олігосахарида та О-полісахаридів. За даними досліджень було встановлено роль ЛПС у виникненні раку шлунка, яку пов'язують з TLR4-залежними шляхами [4].

Висновок. Отже, канцерогенними фракторами, які призводять до розвитку раку шлунка $\epsilon$ цитотоксин-ассоційований ген A (CagA), вакуалізуючий цитотоксин A (VacA) та ліпополісахарид (LPS), які відіграють провідну роль у виникненні пухлинних утворень за допомогою внутрішньоклітинних механізмів. За результатами декількох досліджень було проведено оцінку ерадікації 
Helicobacter pyloriy популяції, яка має підвищену схильність до розвитку раку шлунка. Helicobacter pylori в цьому досліджені знизила ризик розвитку раку шлунка на одну третину, тобто саме ефективне знищення Helicobacter pylori $\epsilon$ одним з основних методів профілактики розвитку пухлини шлунка.

\section{Список використаних джерел:}

1. Rawla, P., \& Barsouk, A. (2019). Epidemiology of gastric cancer: global trends, risk factors and prevention. Przeglad gastroenterologiczny, 14(1), 26-38. DOI: https://dx.doi.org/10.5114\%2Fpg.2018.80001.

2. Fontes L. E. S., Martimbianco A. L. C., Zanin C., Riera R.. (2019). N-acetylcysteine as an adjuvant therapy for Helicobacter pylori eradication. Cochrane Database Syst. Rev, 66(2). 1-66. DOI: https://doi.org/10.1002/14651858.CD012357.pub2.

3. Li, H., Xu, C. X., Gong, R. J., Chi, J. S., Liu, P., \& Liu, X. M. (2019). How does Helicobacter pylori cause gastric cancer through connexins: An opinion review. World journal of gastroenterology, 25(35), 5220-5232. DOI: https://dx.doi.org/10.3748\%2Fwjg.v25.i35.5220.

4. Burkitt, M. D., Duckworth, C. A., Williams, J. M., \& Pritchard, D. M. (2017). Helicobacter pyloriinduced gastric pathology: insights from in vivo and ex vivo models. Disease models \& mechanisms, 10(2), 89-104. DOl: https://dx.doi.org/10.1242\%2Fdmm.027649.

5. Yong, X., Tang, B., Li, B. S., Xie, R., Hu, C. J., Luo, G., ... Yang, S. M. (2015). Helicobacter pylori virulence factor CagA promotes tumorigenesis of gastric cancer via multiple signaling pathways. Cell communication and signaling: CCS, 13, 30. DOl: https://dx.doi.org/10.1186\%2Fs12964-0150111-0.

6. Yamaoka Y. (2010). Mechanisms of disease: Helicobacter pylori virulence factors. Nature reviews. Gastroenterology \& hepatology, 7(11), 629-641. DOl: https://dx.doi.org/10.1038\%2Fnrgastro.2010.154.

\section{РОЛЬ СТРЕСУ У РОЗВИТКУ АКНЕ}

Гулієва Ефсане Мубаріз гизи
студентка
ДЗ «Дніпропетровська медична академія» МОЗ України
УКРАїнА

Мета роботи: аналіз даних літературних джерел щодо впливу стресових ситуацій та їх наслідків на виникнення акне.

Актуальність: акне - це доволі поширена дерматологічна та косметична проблема у сучасному світі. Проблема акне істотно впливає на самопочуття людини, її впевненість у собі та вміння адаптуватися у соціумі, тож вирішення цього питання $є$ одним в провідних напрямків сучасної дерматології.

Методи дослідження: аналіз вітчизняної та зарубіжної літератури щодо проблеми.

Результати:

Вугрова хвороба або акне - це хронічне запальне захворювання сальних залоз. Сальні залози виробляють шкірне сало, що покриває всю поверхню 
шкіри тіла (окрім долонь та підошв) і тим самим виступає захистом від фізичних, хімічних та біологічних подразнень [1].

У процесі ембріогенезу шкіра та нервова система походять з одного зародкового листка і тому взаємозв'язок між цими структурами тісний та складний. Довгий час мала місце думка про парасимпатичну іннервацію шкірних залоз, але на даний момент однозначно відомо, що у іннервації шкіри приймають участь як адренергічні так і холінергічні нервові закінчення. Але у той самий час було встановлено, що основну роль у іннервації залоз шкіри грають адренергічні нервові закінчення [2].

Стресові ситуації, як відомо активують симпато-адреналову систему, що у свою чергу призводить до активації процесу секреції залоз шкіри. У результаті цього маємо виникнення різноманітної висипки, надмірної пітливості та роздратування шкіри у період стресу. У той самий час, стресові ситуації $\epsilon$ причиною зниження активності імунітету, що може стати причиною розвитку інфекційного процесу у залозах [3].

Стресові ситуації спричиняють чисельні зміни у організмі в цілому. Змінюється також і гормональний фон. Так під час стресу підвищується рівень гормону кортизолу, що у свою чергу суттєво впливає на ліпідний обмін підвищуючи вміст ліпідів та тригліцеридів у крові. Цей процес $є$ ще однією ланкою у механізмі збільшення секреції сальних залоз і виникненні акне [4].

Висновки: у результаті аналізу літературних джерел було з'ясовано, що стресова ситуація, а точніше її наслідки грають важливу, якщо не головну роль у виникненні акне. Каскад реакцій, що виникають під впливом стресу спричиняє суттєві зміни у секреції сальних залоз, які у свою чергу призводять до виникнення акне. У зв'язку з таким патомеханізмом даної проблеми у сучасній медицині вже виник напрямок, який отримав назву психодерматологія і розглядає спільні проблеми двох дисциплін [2]. Можливо, за кілька років ця наука винайде рішення дерматологічних проблем, що мають нервово-психічну етіологію.

\section{Список використаних джерел:}

1. Адаскевич, В. П. (2005). Акне вульгарные и розовые. Москва: Медицинская книга; Н.Новгород: Изд-во НГМА.

2. Дарвей, Э. \& Чу, Т. (2005). Акне. Москва: Медпрессинформ.

3. Мавров, И. И., Болотная, Л. А. \& Сербина, И. М. (2007). Основы диагностики и лечения в дерматологии и венерологии: руководство для врачей, интернов и студентов. Харьков: Факт.

4. Молочков, В. А., Семенова, Т. Б., Молочков, А. В. \& Корнева, Л. В. (2006). Акне: клиника, диагностика, лечение. Москва. 
120 - Problèmes et perspectives d'introduction de la recherche scientifique innovante $\bullet$ Volume 3

DOI 10.36074/29.11.2019.v3.20

\section{СЕПСИС}

Санина Екатерина Сергеевна ассистент кафедры общей и клинической иммунологии и аллергологии Харьковский национальный университет имени В.Н.Каразина

Лядова Татьяна Ивановна доктор медицинских наук, профессор, заведующая кафедры общей и клинической иммунологии и аллергологии Харьковский национальный университет имени В.Н.Каразина

УКРАИНА

Сепсис - очень опасный для жизни синдром, обычно вызываемый бактериальной инфекцией. Сепсисом называется реакция иммунной системы организма, которая приводит к дисфункции или недостаточности органов. Критерии синдрома системного воспалительного ответа (SIRS - systemic inflammatory response syndrome) были недавно заменены быстрой последовательной оценкой недостаточности органов (quick Sequential Organ Failure Assessment) в 2016 году, позволяющей быстро провести анализ диссункции органов у постели больного с подозрением на развитие сепсиса или с зарегистрированной инфекцией. Показатель qSOFA включает частоту дыхания 22 вдоха в минуту или более, систолическое артериальное давление 100 мм рт. ст., а также малейшие изменения этих показателей. Для полноты картины тяжелый сепсис определяется как сепсис, осложненный дисфункцией органов.

Синдром полиорганной дисфункции (MODS- Multiple organ dysfunction syndrome) характеризуется прогрессирующей дисфункцией органов у тяжело больного пациента с неспособностью поддерживать гомеостаз без вмешательства. Это конечная стадия при инфекционных состояниях (сепсис, септический шок) и неинфекционных состояниях (например, SIRS из-за панкреатита). Чем больше количество повреждений в органах, тем выше риск смертности, причем наибольший риск связан с дыхательной недостаточностью, требующей искусственной вентиляции легких. Синдромы полиорганной дисфункции могут быть классифицированы как первичные или вторичные.

Первичные MODS являются прямым результатом идентифицируемого повреждения или инсульта с ранней дисфункцией органов (например, почечная недостаточность из-за нефротоксического агента или печеночная недостаточность из-за гепатотоксического агента).

Вторичные MODS - это органная недостаточность, которая не имеет никакой причины и является следствием реакции хозяина (например, острый респираторный дистресс-синдром [ARDS] у людей с панкреатитом).

Следующие параметры используются для оценки дисфункции отдельных органов:

- Со стороны дыхательной системы: Парциальное давление артериального кислорода (РаO 2) / фрракция вдыхаемого кислорода. 
- Данные коагулограммы: количество тромбоцитов, панель коагуляции (время протромбина и частичное время тромбопластина).

- Печеночные пробы: билирубин сыворотки крови.

- Почечные пробы: сывороточный креатинин.

- Сердечно-сосудистая система: гипотензия и потребность в вазопрессорной терапии.

Септический шок определяется как сепсис с гипотонией, требующий вазопрессорной терапии для поддержания среднего кровяного давления более 65 мм рт. ст. и уровня лактата в сыворотке, превышающего 2 ммоль / л ,после проведения адекватных реанимационных мероприятий. Псевдосепсис определяется как лихорадка, лейкоцитоз и гипотензия, возникающие по причинам, отличным от сепсиса. Примерами могут быть клиническая картина, наблюдаемая при интоксикации салицилатом, передозировке метамфетамина или двустороннем кровоизлиянии в надпочечники.

\section{Этиология.}

Сепсис может быть вызван очевидной травмой или инфекцией или более сложной этиологией, такой как перфорация или разрыв внутрибрюшной или тазовой структуры. Другие этиологии могут включать менингит, инфекции головы и шеи, глубокие инфекции шеи, пиелонефрит, почечный абсцесс (внутрипочечный или экстраренальный), острый простатит / абсцесс простаты, тяжелые инфрекции кожи или структуры кожи (например, некротизирующий фасциит), послеоперационные инфекции или системные инфекции, такие как риккетсиозная инфекция.

Клиническая симптоматика

У людей с сепсисом могут быть локализованные симптомы, связанные с конкретным местом или источником инфекции, или могут возникать неспецифические симптомы. Для пациентов с неспецифическими симптомами, как правило, характерна лихорадка, сопровождающаяся тремором. Психический статус может быть нарушен в условиях лихорадки или гипотонии. Пациенты с бактериемией из любого источника часто демонстрируют повышенную частоту дыхания, что приводит к респираторному алкалозу. Кожа пациентов с сепсисом может быть теплой или холодной, в зависимости от адекватности перфузии органов и кожи. Подробный анамнез и физическое обследование необходимы для определения вероятного источника септического процесса. Это помогает клиницисту определить подходящее лечение и антимикробную терапию.

\section{Диагностика.}

Диагноз сепсиса может быть основан на сборе подробного анамнеза, фризикальном обследовании, лабораторных и микробиологических.

Лабораторные исследования включают следующее:

-Общий анализ крови - может показывать повышенный или низкий уровень лейкоцитов, анемию и / или тромбоцитопению.

- Биохимические исследования, такие как маркеры повреждения печени или почек, -свидетельствующие о дисфункции органов.

- Бактериальные культуры. Культуры крови и культуры, специфичные для конкретного места, основанные на клинических подозрениях (например, бак.посев из раны, бак.посев мокроты или бак.посев мочи).

- Исследования мочи (анализ мочи, микроскопия, бак.посев мочи). 
- Некоторые биомаркеры, такие как прокальцитонин и прецепсин - могут быть полезны при диагностике раннего сепсиса и при определении прогноза.

Методы визуализации должны быть сфокусированы на областях, представляющих клинический интерес, основанных на анамнезе и физикальном обследовании, и могут включать в себя следующее:

- Рентгенографрия грудной клетки (чтобы исключить пневмонию и диагностировать другие причины легочных инфильтратов);

-КТ грудной клетки (для дальнейшей оценки пневмонии или другой патологии легких);

-УЗИ брюшной полости (при подозрении на обструкцию желчных путей);

-КТ брюшной полости или МРТ (для оценки предполагаемого небилиарного внутрибрюшного источника инфекции или определения внутрипочечной и экстраренальной патологии);

- Зональная визуализация мягких тканей, включая УЗИ, КТ или МРТ (для оценки возможного абсцесса, сбора жидкости или некротической инфекции кожи);

- КТ-сканирование с контрастным усилением или МРТ головного мозга / шеи (для оценки возможных абсцесса, скопления жидкости или некротической инфекции).

Следующие кардиологические исследования могут быть полезны, если в качестве причины или осложнения инфекции предполагается поражение или заболевание сердца:

1. Электрокардиография (ЭКГ) для оценки нарушений проводимости или задержек или аритмий; перикардит может быть причиной «псевдосепсиса».

2. Уровни сердечного фермента.

3. Эхокардиография для оценки структурных заболеваний сердца.

Инвазивные диагностические процедуры, которые могут быть рассмотрены, включают следующее:

- Торакоцентез (у пациентов с плевральным выпотом).

- Парацентез (у пациентов с асцитом).

- Дренаж жидкостных образований / абсцессов.

- Бронхоскопия с промыванием или другим инвазивным отбором проб (у пациентов с подозрением на пневмонию).

Терапия.

Начальное лечение может включать следующее:

- Прием в стационаре или госпитализация для реанимации и лечения

- Начало эмпирической антибиотикотерапии с последующим целенаправленным лечением на основе данных о культуре, лабораторных данных и визуализации.

- Поддерживающая терапия по мере необходимости; для поддержания перфузии органов и дыхания; своевременное вмешательство с контролем источника инфекции, гемодинамической стабилизацией и поддержкой дыхания.

- Трансфер, если необходимые условия не доступны в данном лечебном учреждении.

Подходящая эмпирическая антимикробная терапия зависит от адекватного охвата предполагаемого (ых) патогена (ов), ответственного за 
септический процесс, потенциальных паттернов устойчивости к противомикробным препаратам и специфических для пациента проблем (таких как лекарственная аллергия или хронические заболевания).

- Инфекции желчевыводящих путей. Типичные бактериальные агенты включают энтеробактерии, кишечные анаэробы и энтерококки. Для лечения используются карбапенемы, пиперациллин-тазобактам, цефалоспорины или хинолоны в сочетании с анаэробным средством, таким как метронидазол.

- Внутрибрюшные и тазовые инфекции: вызываемые обычно Enterobacteriaceae, кишечные анаэробы или энтерококки (карбапенемы, пиперациллин-тазобактам или цефалоспорины или хинолоны в сочетании с анаэробным агентом, таким как метронидазол)

-Уросепсис, вызываемый бактериями из рода Enterobacteriaceae или Enterococcus (карбапенемы, пиперациллин-тазобактам, цефалоспорины, хинолоны или аминогликозиды)

- Пневмококковый сепсис: для терапии используют цефалоспорины третьего поколения, респираторный хинолон (левофлоксацин или моксифлоксацин), карбапенем или ванкомицин, если есть резистентность.

- Сепсис неизвестного происхождения: меропенем, имипенем, пиперациллин-тазобактам или тигециклин; Метронидазол плюс левофлоксацин, цефепим или цефтриаксон могут быть альтернативами.

Раннее хирургическое обследование на предмет предполагаемого внутрибрюшного или тазового сепсиса имеет важное значение. Процедуры, которые могут быть оправданы, зависят от источника инфекции, тяжести сепсиса и клинического статуса пациента, а также других факторов.

Как только этиологический патоген идентифицирован, как правило, с помощью метода культивирования, тогда целесообразно сужение антибиотикотерапии против идентифицированного патогена (например, пенициллин для восприимчивого к пенициллину Streptococcus pneumoniae).

\section{Список использованных источников:}

1. 1.Howell, M. D. \& Davis, A. M. (2017). Management of Sepsis and Septic Shock. JAMA, 317(8), 847-848. DOI: 10.1001/jama.2017.0131.

2. Singer, M., Deutschman, C. S., Seymour, C. W. et al. (2016). The Third International Consensus Definitions for Sepsis and Septic Shock (Sepsis-3). JAMA, 315(8), 801-810.

3. Shankar-Hari, M., Phillips, G. S., Levy, M. L. et al. (2016). Developing a new definition and assessing new clinical criteria for septic shock: for the Third International Consensus Definitions for Sepsis and Septic Shock (Sepsis-3). JAMA, 315(8), 775-787.

4. Савельева, В. С. \& Гельфанда, Б. Р. (ред.). (2010). Сепсис: классификация, клиникодиагностическая концепция и лечение: практическое руководство (2-е изд.). Москва: Медицинское информационное агентство.

5. Bone, R. C., Balk, R. A., Cerra, F. B., Dellinger, R. P., Fein, A. M., Knaus, W. A., Schein, R. M. \& Sibbald, W. J. (1992). Definitions for sepsis and organ failure and guidelines for the use of innovative therapies in sepsis. The ACCP/SCCM Consensus Confe rence Committee. American College of Chest Physicians/Society of Critical Care Medicine. Chest, 101(6), 1644-1655.

6. Seymour, C. W., Liu, V. X., Iwashyna, T.J. et al. (2016). Assessment of Clinical Criteria for Sepsis: For the Third International Consensus Definitions for Sepsis and Septic Shock (Sepsis-3). JAMA, 
315(8), 762-774. DOI:

10.1001/jama.2016.0288.http://jama.jamanetwork.com/article.aspx?articleid=2492876.

7. Deutschman, C. S., Seymour, C. et al. (2016). The Third International Consensus Definitions for Sepsis and Septic Shock (Sepsis-3). JAMA, 315(8), 801-810.

\title{
СИНДРОМ НЕДОСТАТНОСТІ АРОМАТАЗИ
}

\author{
Циганок Олександра Сергіївна \\ здобувач вищої освіти медичного факультету \\ Харківського національного медичного університету \\ УКРӒ̈НА
}

Ароматаза - ензимний комплекс, який складається з двох компонентів. Перший - ароматаза цитохром Р-450 i фрлавопротеїн нікотинамідаденідинуклеотидфосфату у відновленній формі (НАДФ-Н) цитохром P-450 редуктази. Ароматаза Р-450 каталізує перетворення С 19 андрогенних стероїдів в естрогени, а саме біосинтез естрону із андростендіону, естрадіолу із тестостерону. Цей процес отримав назву ароматизація - приєднання кисню 3 утворення френольного А-кільця, характерного для естрогенів. Ароматаза Р-450 - білок із 503 амінокислотних залишків. N-кінцева ділянка молекули, особливо амінокислотні залишки 10-20, дуже важливі для збереження активної конформації ферменту. При пошкодженні перших 10 амінокислотних залишків активність ароматази суттєво не змінюється, але пошкодження 20 амінокислотних залишків призведе до зниження ії активності більш ніж на 95\%. Ген ароматази локалізований на 15 хромосомі, складається з 10 екзонів, кодуючими з яких $\epsilon$ лише 9 (2-10) [1].

Ароматаза Р-450 важливий регулятор нормального функціонування організму, який знайдено в таких тканинах: головний мозок, шкіра, кістки, жирова тканина, кровоносні судини, печінка, ендометрій, плацента, гонади. Для цього фермента характерна гістоспецифічність - 5`кінці мають особливості в різних тканинах. А також ароматаза Р-450 була знайдена в ендометріоїдних гетеротопіях, в ткининах лейоміоми, при раку ендометрую та раку молочної залози.

Синдром недостатності ароматази - дуже рідкісне захворювання, яке розвивається при дефректі гена СҮР19 А1 [2]. На сьогоднішній день відомо близько 36 випадків цього захворювання серед різних етнічних груп та на різних континентах, включаючи Єгипет, Індію та країни Європи. Синдром недостатності ароматази передається по аутосомно-рецесивному типу. У пацієнтів з дефектом ароматази було виявлено біля 30 різноманітних мутацій включаючи невеликі делеції та вставки, мутації сайта сплайсинга і одну велику внутрішньо генну делецію. Більшість мутацій знаходилися в екзонах 9, 10 .

Мутація гену CYP19 A1 призводить до формування DSD (differences sex envelopment) різного ступеня. DSD відноситься до групи вроджених станів, які 
пов язані з атиповим розвитком хромосомної, гонадної чи анатомічної статі. Клінічні прояви при народженні виражені тільки у осіб жіночої статі, так як особи чоловічої статі проходять нормальну статеву диференціацію. В пре- та постпубертатному періоді виявляються ознаки євнухоїдизму, пацієнти вирізняються високим зростом через відкриті «зони росту» в епіфізах трубчастих кісток. Також виявлено зниження кількості сперматозоїдів і їх рухливості. Це пов'язано з регулюючою функцією ароматази в підтриманні балансу між андрогенами та естрогенами. Слід відзначити, що дефіцит ароматази не впливає на психосексуальний розвиток і не викликає проблем 3 гендерною ідентифрікацією.

Клінічні прояви у осіб жіночої статі залежить від активності данного ферменту та віку. При народженні проявляється гіпергонадотропним гіпогонадизмом, внутрішньоутробною вірілізацією (по шкалі Прадера від 2 до 4). В той же час, в період новонародженості досить важко встановити правильний діагноз, так як до 2 місячного віку не виявляються характерні зміни гормонів (високий рівень гонадотропінів та андрогенів, при мінімальному значенні естрогенів в крові) [3].

В період статевого дозрівання відмічається недорозвиток вторинних статевих ознак, первинна аменорея, а надалі і безпліддя, а також незалежно від статі остеопороз. У пацієнтів з десріцитом ароматази відсутній постійний фенотип яєчників (нормальна морфологія, великі полікістозні яєчники).

Паралельно, під час вагітності, можуть виникати ознаки вірілізації і у матері: поява акне, зниження тембру голосу, гіпертрофрія клітора, які зникають через деякий час після пологів [1]. Ці ознаки можуть не формуватися при передчасних пологах або при частковій активності ароматази.

В даний час $€$ не багато документації про вплив заміщення естрогену для попередження дефріциту естрогену у жінок з дефріцитом ароматази. Більше того, не має єдиної думки відносно дозування і віку початку замісної терапії естрогенами. 3 іншого боку, данні відносно раннього початку лікування та довготривалого спостереження за пацієнтами вкрай рідкі. В огляді лікування дефіциту ароматази зазнається, що замісна терапія естрогенами може бути почата уже 3 двохрічного віку в найменш можливій дозі естрогену для попередження розвитку кист яєчників, уникнення раннього розвитку молочних залоз, прискорення росту кісток [3].

Таким чином, підвищення знання про фенотипову мінливість, дослідження методів лікування та діагностики у жінок 3 недостатністю ароматази $є$ необхідними для підвищення частоти виявлення цього захворювання та підвищення ефективності лікування і зменшення частоти та рівня ускладнень. Вірілізованих осіб жіночої статі слід перевіряти на предмет дефріциту ароматази після виключення вродженої гіперплазії наднирників (уникнення наднирникового кризу після призначенної терапії).

\section{Список використаних джерел:}

1. Савіна, В. О., Потин, В. В. \& Тарасова, М. А. (2010). Роль ароматази в патогенезі первиннооваріальної недостатності. Журнал акушерства та жіночих хвороб, (6), 85-90. Вилучено 3 https://cyberleninka.ru/article/n/rol-aromatazy-v-patogeneze-pervichno-ovarialnoynedostatochnosti 
2. Unal, E. \& Yıldıım, R. \& Taş, F. (2018). Aromatase Deficiency due to a Novel Mutation in CYP19A1 Gene. J Clin Res Pediatr Endocrinol, (4), 377-381. Retrieved from https://www.ncbi.nlm.nih.gov/pubmed/29553041

3. Dursun F \& Ceylaner S. (2019). A Novel Homozygous CYP19A1 Gene Mutation: Aromatase Deficiency Mimicking Congenital Adrenal Hyperplasia. J Clin Res Pediatr Endocrinol, (2), 196201. Retrieved from https://www.ncbi.nIm.nih.gov/pubmed/30074481

DOI 10.36074/29.11.2019.v3.21

\title{
СРАВНИТЕЛЬНЫЙ АНАЛИЗ МЕТОДОВ СОВРЕМЕННОЙ РЕКОНСТРУКТИВНОЙ ХИРУРГИИ ТАЗОВОГО ДНА ПОСЛЕ ПРОВЕДЕНИЯ ЭКСТРАЛЕВАТОРНОЙ БРЮШНО- ПРОМЕЖНОСТНОЙ ЭКСТИРПАЦИИ ПРЯМОЙ КИШКИ ПРИ ЕЁ ОНКОЛОГИИ
}

\begin{abstract}
Чеботенко Олег Романович
соискатель высшего образования медицинского фракультета

Харьковский национальный медицинский университет

Йолдаш Денис Бекирович

соискатель высшего образования медицинского фракультета

Харьковский национальный медицинский университет

Научный руководитель: Коломенский Алексей Геннадьевич

ассистент кафедры общей хирургии №1

Харьковский национальный медицинский университет

УКРАИНА
\end{abstract}

\section{Введение.}

За последними данными, в 21-ом столетии проблемные вопросы, ввиду хирургического лечения людей с онкозаболеваниями прямой кишки являются одними из наиболее значимых вопросов в онкологии и реконструктивной хирургии. Согласно опубликованным данным Национального канцеррегистра, за прошедшие 10 лет, заболеваемость онкологией прямой кишки в Украине совершила ростовой скачок на 17,8 \% ,а смертность превысила предыдущий показатель на 14\%. Основным методом лечения онкологии прямой кишки на инновационном этапе онкохирургии, является экстралеваторная брюшно-промежностная экстирпация. При этом послеоперационные осложнения ввиду таких как: инфекционные осложнения, промежностные грыжи, кровотечения и обширные дефекты при несовершенстве реконструкции тазового дна, - возросли $[1,2]$.

С данной тенденцией возникновения осложнений, на сегодня осуществляются значительные изменения в виде уменьшения их в послеоперационный период, путем внедрения новых методов реконструкции тазового дна, нуждаемость в которых обусловлено широким применением 
методики экстралеваторной брюшно-промежностной экстирпации прямой кишки при её онкологии.

Нужно отметить, что к новым методам лечения выдвигаются требования обеспечить эффрективное лечение, а также обеспечить необходимый уровень качества жизни, путём максимально возможного сохранения структурной и функциональной целостности организма. В данный час к данным методам относят три основных методики реконструктивной пластики тазового дна: простое ушивание тканей промежности (ПУТП), пластика тазового дна с использованием эндопротеза (аллопластика) и пластика тазового дна с использованием мышечного лоскута (миопластика). Из-за приоритетности выбора, использования той либо иной методики реконструктивной пластики, возникают дискуссии между представителями различных хирургических школ, а именно по поводу эффективности лечения и низкой частоты возникновения осложнений. В следствии разбежности данных, возникает необходимость в самостоятельном проведении сравнительного анализа, его трактовании и обобщении об эффективности этих видов методик реконструктивной пластики тазового дна $[2,3,4]$.

Цель работы.

Изучить методы современной реконструктивной пластики тазового дна при экстралеваторной брюшно-промежностной экстирпации (ЭлБПЭ) в онкоколоректальной хирургии. Провести сравнительный анализ эфффективности и частоты возникновения возможный осложнений, после различных методик современной реконструктивной пластики тазового дна при ЭлБПЭ. Выявить преимущества данных методик в сравнении друг с другом, с последующим их обобщением с целью возможного корректирования нынешних протоколов лечения по данной нозологии.

\section{Материалы и методы.}

Исследования проводились на базе Харьковского Областного Центра Онкологии. Работа проводилась в периоде с февраля 2019 по ноябрь 2019 года. Были собраны статистические данные и проведен сравнительный анализ результатов проведения реконструктивной пластики после перенесенной ЭлБПЭ прямой кишки при её онкологии. В основе исследования лежит анализ результатов 33 больных с перенесённой ЭлБПЭ прямой кишки. Среди них 15 (45,5\%) составили мужчины, и 18 (54,5\%) - женщины. Операция проходила с целью радикального хирургического лечения рака прямой кишки в плановом порядке. С целесообразностью наиболее качественного анализа результатов, все пациенты были систематизированы и разделены, в соответствии с видом проведённой им пластикой тазового дна и в соответствии полученной химиотерапией на 3 группы и 6 подгрупп (табл. 1).

Методика выполнения пластик тазового дна путём простого ушивания тканей промежности, заключается в послойном сведении узловыми швами краёв подкожной жировой клетчатки и кожи, без затрагивания мышечной ткани.

Методика выполнения пластики дефекта тазового дна путём эндопротезирования (аллопластика), выполняется путем в размещения, подобранного по размеру, эндопротеза в область послеоперационного дефекта. 


\section{Распределение больных по группам А,B,C в зависимости от вида лечения и произведённой реконструктивной пластики}

\begin{tabular}{|c|c|c|c|c|c|}
\hline \multicolumn{6}{|c|}{$\begin{array}{c}\text { Количество людей перенёсших экстралеваторную брюшно-промежностною экстрипцию прямой } \\
\text { кишки }(\mathrm{N}=33)\end{array}$} \\
\hline \multicolumn{2}{|c|}{$\begin{array}{c}\text { Группа А } \\
\text { Простая пластика (ПУТП) } \\
\mathrm{N}=11(33,3 \%) \\
\end{array}$} & \multicolumn{2}{|c|}{$\begin{array}{c}\text { Группа В } \\
\text { Аллопластика } \\
\text { N=9 }(27,3 \%)\end{array}$} & \multicolumn{2}{|c|}{$\begin{array}{c}\text { Группа C } \\
\text { Миопластика } \\
\mathrm{N}=13(39,4) \\
\end{array}$} \\
\hline \multicolumn{6}{|c|}{ В соответствии с полученной химиотерапией (XТ) } \\
\hline $\begin{array}{c}\text { Без } \mathrm{XT} \\
\mathrm{N}=3(27,3 \%)\end{array}$ & $\begin{array}{l}C X T \\
N=8(72,7 \%)\end{array}$ & $\begin{array}{c}\text { Без XT } \\
N=3(33,3 \%)\end{array}$ & $\begin{array}{c}C \times T \\
N=6(66,7 \%)\end{array}$ & $\begin{array}{c}\text { Без } \mathrm{XT} \\
\mathrm{N}=4(30,8 \%)\end{array}$ & $\begin{array}{rl} & C \times T \\
N & 969,2 \%\end{array}$ \\
\hline
\end{tabular}

Методика выполнения пластики тазового дна путём миопластики, заключается путём выкраивания васкуляризированного мышечного лоскута с последующим его перемещением в область послеоперационного дефекта.

Оценка результатов хирургических методик проводилась в послеоперационном периоде, ввиду показателей осложнений (кровотечения, инфекционные осложнения, появление промежностных грыж, обширные десекты промежности). Клинические осложнения, возникшие, после проведения реконструктивной пластики оценивались с использованием шкалы Dindo (Шкала классификации хирургических осложнений).

Статистическая обработка данных проводилась с использованием программного обеспечения и пакета StatSoft STATISTICA 10 Russian Portable for Windows7. Достоверность данных оценивалась с использованием параметрических и непараметрических методов. Результаты считались достоверными при показатели р<0,05.

\section{Результаты и обсуждение.}

Была оценена частота осложнений у больных в послеоперационном периоде, вне зависимости от принадлежности к какой-либо группе. Также были проанализированы осложнения, возникшие в послеоперационный период, после проведения определенного вида пластики. Оценивалась степень выраженности какого-либо осложнения с использованием шкалы классификации хирургических осложнений Dindo. При комлексном анализе выявлено, что вид осложнения, его частота, и степень проявления не зависит от пола.

Осложнение в виде частоты кровотечений из раны в промежностной области были выявлены у больных группы А и С (табл. 2).

Кровотечение как осложнение после проведенной пластики тазового дна наблюдалось в основном у больных получивших химиотерапию. Стоит заметить, что было выявлено случай возникновения кровотечения в группе больных не прошедших химиотерапию после проведенной им миопластики тазового дна.

Проведено сравнение частоты возникновения инфекционного осложнения. Наиболее превосходящий результат показала пластика тазового дна в виде методики простого ушивания тканей промежности - 63,3\%. Показатели частоты инфекционного осложнения после пластики тазового дня с помощью 
методики аллопластики и миопластики составили $32,3 \%$ и 23,1\% соответственно. После перенесенной аллопластики или миопластики осложнения возникали достаточно реже, чем при простом ушивании тканей промежности.

Таблица 2

Частота кровотечений в послеоперационный период в зависимости от вида пластики

\begin{tabular}{|c|c|c|c|c|c|c|}
\hline Вид пластики & \multicolumn{2}{|c|}{$\begin{array}{c}\text { Простое ушивание } \\
\text { тканей промежности }\end{array}$} & \multicolumn{2}{|c|}{ Аллопластика } & \multicolumn{2}{c|}{ Миопластика } \\
\hline $\begin{array}{c}\text { Количество } \\
\text { больных }\end{array}$ & \multicolumn{2}{|c|}{11} & \multicolumn{2}{|c|}{9} & \multicolumn{2}{c|}{13} \\
\hline Тип лечения & Без ХT & С ХT & Без ХT & С ХT & Без XT & С XT \\
\hline $\begin{array}{c}\text { Частота } \\
\text { кровотечений }\end{array}$ & - & $3(27,3 \%)$ & - & $1(11,1 \%)$ & $1(0,8 \%)$ & $2(15,4 \%)$ \\
\hline
\end{tabular}

В независимости от выбранной методики пластики тазового дна было выявлено, что частота возникновения инфекционного осложнения выше в группе больных А. У больных группы В, которые не получали химиотерапию, не было обнаружено инфекционного осложнения в отличи от получавших её $66,7 \%$. В группе С показатели частоты инфекционного осложнения при лечении с помощью химиотерапии и без прибегания к ней составили равные значения $33,3 \%$ соответственно (табл. 3 ).

Таблица 3

\section{Зависимость частоты инфекционного осложнения от применения химиотерапии}

\begin{tabular}{|c|c|c|c|c|c|c|}
\hline Группа больных & \multicolumn{2}{|c|}{$\begin{array}{c}\text { Группа А } \\
\text { (Простое ушивание } \\
\text { тканей промежности) }\end{array}$} & \multicolumn{2}{|c|}{$\begin{array}{c}\text { Группа В } \\
\text { (Аллопластика) }\end{array}$} & \multicolumn{2}{|c|}{$\begin{array}{c}\text { Группа С } \\
\text { (Миопластика) }\end{array}$} \\
\hline $\begin{array}{c}\text { Общее } \\
\text { количество } \\
\text { больных с } \\
\text { инфекционным } \\
\text { осложнением } \\
\end{array}$ & \multicolumn{2}{|c|}{7} & \multicolumn{2}{|c|}{3} & \multicolumn{2}{|c|}{3} \\
\hline Тип лечения & Без XT & XT & Без XT & XT & Без XT & $\mathrm{XT}$ \\
\hline $\begin{array}{c}\text { Частота } \\
\text { инфекционных } \\
\text { осложнений } \\
\end{array}$ & $\begin{array}{c}3 \\
(42,9 \%)^{*}\end{array}$ & $\begin{array}{c}4 \\
(57,1 \%)^{*}\end{array}$ & - & $\begin{array}{c}2 \\
(66,7 \%)^{*}\end{array}$ & $\begin{array}{c}1 \\
(33,3 \%)^{*}\end{array}$ & $\begin{array}{c}1 \\
(33,3 \%)^{*}\end{array}$ \\
\hline
\end{tabular}

${ }^{*} p<0,05$ - достоверность различий частоты инфекционных осложнений при отсутствии химиотерапии и при её применении после проведённой пластики тазового дна.

В послеоперационном периоде образование промежностных грыж наблюдалось только в группе больных перенесших пластику тазового дна в виду простого ушивания тканей промежности - в $4(36,4 \%)$ случаев. В случае использования аллопластики или миопластики, образование грыж не выявлено (табл.4). 
130 • Problèmes et perspectives d'introduction de la recherche scientifique innovante $\bullet$ Volume 3

Таблица 4

\section{Частота образования промежностных грыж в зависимости от вида пластики тазового дна}

\begin{tabular}{|c|c|c|c|}
\hline Вид пластики & $\begin{array}{c}\text { Простое ушивание } \\
\text { тканей промежности }\end{array}$ & Аллопластика & Миопластика \\
\hline $\begin{array}{c}\text { Частота появления } \\
\text { промежностных грыж }\end{array}$ & $4(36,4 \%)^{*}$ & Грыж не выявлено & Грыж не выявлено \\
\hline
\end{tabular}

${ }^{*} p<0,05$ - достоверность различий частоты образования промежностных грыж в зависимости от вида проведённой пластики тазового дна.

Таблица 5

Зависимость степени тяжести осложнения в виду дефекта тазового дна по шкале Dindo в зависимости от вида пластики тазового дна

\begin{tabular}{|c|c|c|c|c|c|c|c|c|c|}
\hline $\begin{array}{c}\text { Группа } \\
\text { больных }\end{array}$ & \multicolumn{3}{|c|}{ Группа A } & \multicolumn{3}{|c|}{ Группа В } & \multicolumn{3}{|c|}{ Группа C } \\
\hline $\begin{array}{c}\text { Вид } \\
\text { пластики }\end{array}$ & \multicolumn{3}{|c|}{$\begin{array}{c}\text { Простое ушивание } \\
\text { тканей промежности }\end{array}$} & \multicolumn{3}{|c|}{ Аллопластика } & \multicolumn{3}{|c|}{ Миопластика } \\
\hline $\begin{array}{c}\text { Всего } \\
\text { больных }\end{array}$ & \multicolumn{3}{|c|}{7} & \multicolumn{3}{|c|}{3} & \multicolumn{3}{|c|}{4} \\
\hline $\begin{array}{c}\text { Степень по } \\
\text { шкале Dindo }\end{array}$ & II & III & IV & II & III & IV & II & III & IV \\
\hline $\begin{array}{c}\text { Количество } \\
\text { больных }\end{array}$ & $\begin{array}{c}5 \\
(71,4 \%)\end{array}$ & $\begin{array}{c}2 \\
(28,6)\end{array}$ & - & $\begin{array}{c}2 \\
(66,7 \%)\end{array}$ & $\begin{array}{c}1 \\
(33,3 \%)\end{array}$ & - & $\begin{array}{c}2 \\
(50 \%)\end{array}$ & $\begin{array}{c}1 \\
(25 \%)\end{array}$ & $\begin{array}{c}1 \\
(25 \%)\end{array}$ \\
\hline
\end{tabular}

При проведении анализа степени тяжести осложнения дефекта тазового дна, было замечено что во всех группах больных определялась II степень тяжести (Группа A - 5(71,4\%), группа В - 2(66,7\%), группа C - 2(50\%)). Степень тяжести III была определена в большем количестве в группе A - 2(28,6). Степень осложнения IV была выявлена только в группе больных группе больных с миопластикой - 1(25\%) (табл. 5).

\section{Выводы.}

1. Выбор реконструктивной методики по закрытию послеоперационного дефекта напрямую влияет на частоту возможных осложнений у больных, перенесших ЭлБПЭ прямой кишки. После выполнения простой пластики частота появления постоперационных осложнений в виду кровотечения составляет $27,3 \%$, чем после пластики с использованием эндопротеза $11,1 \%$ и миопластики $16,2 \%$.

2. Наиболее значимая эфффективность лечения и низкая частота возникновений осложнений определяется у таких методик пластики тазового дна, как аллопластика и миопластика.

3. Количество возникновения постоперационных промежностных грыж, кровотечений инфекционных осложнений напрямую зависит от выбора той или иной методики. Снижение их количества достигается путём применения в первую очередь аллопластики и миопластики вместо простой пластики (ПУТП).

4. Одним из значимых преимуществ миопластики, является использование собственной васкуляризированной мышечной ткани, что существенно снижает риск отторжения её организмом.

5. Основным преимуществом выполнения простого ушивания тканей промежности является возможность использования данной методики у пожилых и ослабленных пациентов, в отличии от аллопластики и 
миопластики, у которых основными преимуществами выполнения являются простота выполнения и невысокая частота послеоперационных инфекционных осложнений $32,3 \%$ и $23,1 \%$ соответственно.

\title{
Список используемых источников:
}

1. Гордеев, С. С., Иванов, В. А., Кузьмичев, Д. В., Тамразов, Р. И., Расулов, А. О. (2017). Методы реконструкции промежностных ран после брюшно-промежностной экстирпации прямой кишки. Научно-практический медицинский журнал «Тазовая хирургия и онкология», 7(2), 53-59.

2. Доманский, Н. А., Семиглазов, Б. Б., Карачун, А. М., Лебедев, К. К., Самсонов, Д. В., Доманский, А. А. (2018). Результаты использования миопластики для закрытия дефекта тазового дна после экстралеваторной брюшно-промежностной экстирпации прямой кишки. Сибирский онкологический журнал, 17(6), 35-40.

3. Беляев, В. С., Несытых, А. А., Дыхно, Ю. А., Версенёв, А. А., Лалетин, И. А., Козина, Ю. В. (2018). ПЛАСТИКА ТАЗОВОГО ДНА ПОСЛЕ ЭКСТРАЛЕВАТОРНОЙ БРЮШНОПРОМЕЖНОСТНОЙ ЭКСТИРПАЦИИ ПРЯМОЙ КИШКИ ПЕРЕМЕЩЕННЫМ ЛОСКУТОМ БОЛЬШОЙ ЯГОДИЧНОЙ МЫШЦЫ. Сибирский онкологический журнал, 17(2), 118-122.

4. Бондарь, Г. В., Башеев, В. Х., Думанский, Ю. В. (2009). Успехи и проблемы лечения рака прямой кишки. Новообразования, (3-4), 19-24.

5. Рак в Україні, 2017-2018. Захворюваність, смертність, показники діяльності онкологічної служби. (2019) Бюл. Нац. канцер-реєстру України, (19).

6. Щепотін, І. Б., Колесник, О. О., Приймак, В. В. та ін. (2010). Оптимізація хірургічного лікування хворих на рак дистального відділу прямої кишки. Онкологія, 12(2), 70-72.

DOI 10.36074/29.11.2019.v3.22

\section{СТАН НАВКОЛИШНЬОГО СЕРЕДОВИЩА ЯК ФАКТОР РИЗИКУ РОЗВИТКУ ДИТЯЧОГО АУТИЗМУ}

\author{
НАУКОВО-ДОСЛІДНА ГРУПА: \\ Кателевська Наталія Миколаївна \\ канд. мед. наук, доцент кафедри гігієни та екології №1 \\ Харківський національний медичний університет \\ Нестеренко Валентина Геннадіївна \\ канд. мед. наук., доцент кафедри гігієни та екології №1 \\ Харківський національний медичний університет \\ Соколова Ірина Вадимівна \\ здобувач вищої освіти I медичного фракультету \\ Харківський національний медичний університет
} УKPAÏHA

Актуальність: За даними CDC у Сполучених Штатах Америки за період 2004-2018 років частота виявлення захворювання збільшилася в 3 рази [1]. Багато вчених, завдяки нещодавнім дослідженням, пов'язують подібну статистику з проблемою забруднення навколишнього середовища - однією 3 найсерйозніших та найголовніших для XXI століття [3]. 
Мета: Вивчити вплив погіршення стану навколишнього середовища на розвиток дитячого аутизму.

Результати: Було встановлено, що найбільший вплив із безлічі фракторів навколишнього середовища відіграє саме забруднене повітря, що згубно діє на розвиток плоду, зокрема збільшує вірогідність виникнення дитячого аутизму.

Інфантильний (дитячий) аутизм або синдром Каннера - розлад, що набирає оберти з шаленою швидкістю: за результатами Всесвітньої організації охорони здоров'я станом на 2018 рік приблизно одна дитина із 160 у світі має дане захворювання [2]. За даними МОЗ України 2014 року на території України проживало 3200 людей з таким діагнозом, проте ці цифри не відповідають реальним і $€$ набагато більшими.

Основними зовнішніми проявами є:

- Емоційний контакт з оточуючим світом встановлюється досить тяжко. Діти мають проблеми з вираженням і розумінням як власних емоцій, так і людей 3 якими вони контактують.

- Стереотипність та одноманітність дій: присутні надзвичайно важливі для хворого «ритуали», які повністю захоплюють їх увагу, домінування вузьких, часто повторюваних тем у розмові. За намаганням порушити певний порядок дій неодмінно слідує активний супротив.

- Затримка і порушення комунікативних функцій мови - до повного ігнорування поставлених питань та уникнення розмов.

- Ранній прояв вищезазначених ознак: наразі існують тести, здатні виявити хворобу у віці від двох років.

Достеменно відомо, що подібні розлади виникають внаслідок порушення розвитку головного мозку, проте вченими досі не було чітко пояснено механізму на клітинному та системному рівнях. Саме через брак знань у патогенезі захворювання, що досить швидко кількісно прогресує, наразі активно проводяться дослідження.

У 2018 році в журналі Enviromental Internation були опубліковані результати роботи групи шанхайських та австралійських вчених щодо залежності частоти захворюваності дітей аутизмом від якості повітря у Китаї [3]. Базувалося дослідження на виявленні впливу твердих часточок РM1, РM2.5 та PM10 (відповідно до збільшення розмірів). За результатами виявилося, що тривалого контакту с цими частками достатньо для того, щоб викликати неврологічні ефекти, i, хоча провідними фракторами виникнення аутизму $є$ генетичні модифікації, подібні контакти суттєво підвищують ризик.

У журналі Environmental Health Perspectives у 2012 році була опублікована стаття, в якій було сказано, що поліхлоровані біфеніли, що досить широко використовують у промисловості, можуть викликати мутації у хромосомі 15. Припускають, що ця мутація перешкоджає виведенню ПБХ з організму, а вже саме його накопичення - безпосередньо до розвитку аутизму. Окрім того, у дослідженні на лабораторних щурах було виявлено, що ці та подібні їм речовини порушують розвиток нормальних нейронних зв'язків між ключовими клітинами мозку, що також може бути сприйняте як маркер захворювання $[4,5]$.

Висновки: За результатами дослідження, було встановлено зв'язок між станом середовища проживання людей та приростом хворих на аутизм. 
Проживання у забруднених промислових районах $є$ певним тригером для виникнення дитячого аутизму. Привернення уваги до хвороби як наслідку проблем 3 екологією, дозволить виробити найкращу методику для попередження збільшення в геометричній прогресії тих, хто має подібну патологію.

\section{Список використаних джерел:}

1. Baio, J. (2014). Prevalence of Autism Spectrum Disorder Among Children Aged 8 Years. Retrieved from https://www.cdc.gov/mmwr/volumes/67/ss/ss6706a1.htm?s_cid=ss6706a1_w

2. Autism spectrum disorders (2018). Retrieved from https://www.who.int/news-room/factsheets/detail/autism-spectrum-disorders [in English]

3. Early life exposure to particulate matter air pollution (PM1, PM2.5 and PM10) and autism in Shanghai, China: A case-control study. (2018). Retrieved from

4. https://www.sciencedirect.com/science/article/pii/S0160412018313242?via\%3Dihub

5. Wayman, G. A, Bose, D.D. \& Yang, D. (2012). PCB-95 Modulates the Calcium-Dependent Signaling Pathway Responsible for Activity-Dependent Dendritic Growth. Environ Health Perspect, 120.

6. Landrigan, P.J., Lambertini, L. \& Birnbaum, L.S. (2012). A Research Strategy to Discover the Environmental Causes of Autism and Neurodevelopmental Disabilities. Environ Health Perspect, 120.

DOI 10.36074/29.11.2019.v3.23

\section{СТРУКТУРНО - ФУНКЦІОНАЛЬНІ ЗМІНИ ВНУТРІШНІХ ОРГАНІВ ЩУРІВ ПРИ $\mathrm{CCL}_{4}$ - IНТОКСИКАЦІЇ}

\section{Татаріна Ольга Володимирівна}

канд. мед. наук, доцент, доцент кафедри ортопедичної стоматології Вінницький національний медичний університет ім. М. І. Пирогова

УKPAÏHA

Гепаторенальний або нирково-печінковий синдром (ГРС) - важка вторинна прогресуюча функціональна ниркова недостатність на фоні прогресуючого захворювання печінки [1].

Гострий і хронічний гепаторенальний синдром [2, 3] супроводжують вірусні гепатити, алкогольний цироз, гепатоцелюлярна карцинома (ГЦК), метастатичне враження печінки. Основним патогенетичним механізмом ГРН вважають наростаючу недостатність фрункції нирок пов'язаних 3 вазоконстрикцією і обумовленою вираженими порушеннями елімінації ксенобіотиків в гепатоцитах $[4,5]$.

В той же час порушення детоксикаційної функції печінки пов'язані 3 інактивацією ферментів біотрансформації можуть бути обумовлені негативним впливом на мікросомальні фрерменти печінки, ряду лікарських речовин, ендотоксинів, внесених токсинів, харчових продуктів [5-7]. Такий вплив призводить до ураження печінки і вторинним нефропатіям [8-10]. Для таких 
патологічних станів використовують термін псевдогепаторенальний синдром (ПГРС).

При вивченні ГРС відмічається наявність структурних змін в печінці і нирках. Однак динаміка цих структурних змін описана достатньо фрагментарна. Окрім того, в доступній літературі по ГРС не описані зміни в інших органах, що не дозволяє робити висновок про системність або локальність ГРС.

Виходячи із вищесказаного метою роботи $\epsilon$ оцінка структурнофрункціональних змін в печінці, нирках і селезінці при розвитку ПГРС, обумовленого тетрахлоридвуглецевою інтоксикацією у щурів.

Матеріали і методи.

Матеріалами для цієї роботи стали результати отримані при дослідженні 76 білих щурів - самців роду Вістар аутогібридного розведення масою тіла 180 - 200 г. Утримання тварин і робота 3 ними здійснювалась відповідно 3 Директивою 2010/63/EU Європейського парламенту і ради від 22.09.2010 по захисту тварин, які використовуються з науковою метою [11] і наказу $\mathrm{MOH}, \mathrm{M}$ та С України №249 від 01.03.2012р. [12].

У відповідності до мети роботи тварини були ранжовані на 2 групи:

І. Група - 16 тварин, які не піддавались ніякому впливу і результати дослідження яких слугували контролем.

II. Група - 60 тварин, яким моделювали тетрахлорвуглецеву інтоксикацію введенням підшкірно 0.5 мл $\mathrm{CCL}_{4}$.

Тварин виводили з експерименту на 3 і 7 день після введення $\mathrm{CCL}_{4}$.

Після виведення із експерименту тварин проводили аутопсію і вилучали шматочки печінки, нирок, селезінки. Отриманий матеріал ділили на 2 частини одну частину фіксували в 4\% параформальдегіді на протязі 36 годин, потім проводили через спирти, зростаючої концентрації і змивали в целоїдин. 3 отриманих блоків виготовляли мікротомні зрізи товщиною 7 мкм., які зафарбовували гематоксилін-еозином і вивчали за допомогою світлового мікроскопа.

Другу частину матеріалу заморозили сухою вугільною кислотою $\left(\mathrm{t}^{\circ}=-44^{\circ} \mathrm{C}\right)$ і виготовляли кріостатні зрізи товщиною 11-12 мкм. На яких по прописам Лойди визначали активність сукцинатдегідрогенази (СДГ), лактатдегідрогенази (ЛДГ) і глутаматдегідрогенази (ГДГ). Активність ферментів визначаємо напівкількісним методом. Результати піддавались стандартній статистичній обробці з використанням коефіцієнта Стьюдента.

\section{Результати та їх обговорення.}

Дослідження печінки. На 3-ю добу після введення $\mathrm{CCL}_{4}$ спостерігаємо що, часточковість в організації паренхіми змазана за рахунок стоншення міжчасточкового шару, місцями вони не читаються. В судинах тріад спостерігається плазмостаз. Центральна вена звужена, навколо неї скупчення діапедезно виведених лімфоцитів. Гепатоцити невеликі по розміру, розміщуються в часточці неупорядковано. Оскільки балкова організація часточки відсутня, міжбалкові простори не читаються. Між гепатоцитами зустрічаються клітини витягнутої форми з овальними темними ядрами, можливо це клітини Купфера.

Структура гепатоцитів центральної і периферичної зони відрізняються. Для гепатоцитів центральної зони характерні невеликі розміри, гомогенна середньо зафарбована цитоплазма. Ядра в частині цих клітин середніх 
розмірів помірної зафарбованості, в частині гепатоцитів ядра пікнотичні, темноофарбовані.

За даними гістоензимологічних досліджень, активність СДГ в гепатоцитах

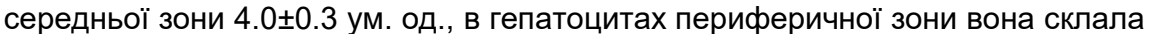
$7.0 \pm 0.1$ ум. од. Активність ЛДГ також неоднакова по зрізу. В гепатоцитах центральної зони вона склала $5.0 \pm 0.09$ ум. од., в гепатоцитах периферичної $7.0 \pm 0.13$ ум. од. Більш висока активність досліджуваних ферментів дозволяє допускати, що репаративні можливості периферичних клітин збережені.

Що стосується активності ГДГ, то в гепатоцитах центральної зони вона

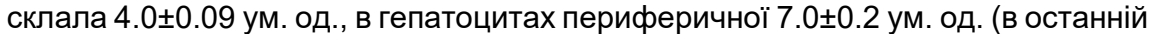
вона підвищена).

Дослідження печінки на 7 добу експерименту після введення $\mathrm{CCL}_{4}$ показали що, чіткості в часточковій структурі паренхіми печінки, завдяки стоншенню, а місцями і зникненню між часточкових перетинок (в порівнянні 3 результатами 3-ої доби експерименту) не додалось. В судинах часточок також спостерігається явище плазмостазу. На більшій частині часточки гепатоцити розташовуються невпорядковано, тільки в невеликій зоні навколо центральної вени можна відзначити утворення, які схожі на балки, але за рахунок набряклості цієї зони вони досить віддалені один від одного. Більшість гепатоцитів середніх і малих розмірів, цитоплазма грудкувата, бліда. Ядра дрібні, темні (пікнотичні). У ряді гепатоцитів визначаються вакуолі невеликих розмірів.

Активність СДГ в гепатоцитах середньої зони $3.0 \pm 0.6$ ум. од., в гепатоцитах периферичної зони вона склала $4.5 \pm 0.5$ ум. од. Активність ЛДГ в гепатоцитах центральної зони склала $7.0 \pm 0.35$ ум. од., в гепатоцитах

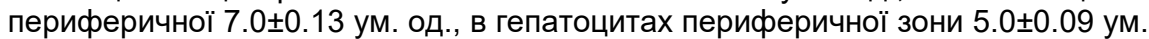
од. Має місце виснаження можливостей окисно-відновних ферментів.

Активність ГДГ в центрі $6.0 \pm 0.3$ ум. од., на периферії $5.0 \pm 1.0$ ум. од., тобто у периферичних клітин активно використовується альтернативний субстрат.

Наступним органом, який ми досліджували були нирки.

На третю добу експерименту розмір і зовнішній вигляд нирок піддослідних щурів (II група) не відрізнявся від щурів контрольної групи (I група), крім кольору. Колір нирок щурів з І-ої групи був сірувато-коричневим замість коричневого. При макроскопічному дослідженні в корковій речовині нирки ниркові тільця розміщені групами. В частині ниркових тілець капілярний клубочок круглястий, ендотеліоцити частково розміщуються безпорядно, 3 набряклою цитоплазмою і частина з них містить вакуолі. В звивистих канальцях епітелій розміщений в один шар. Базальна мембрана звичайного виду. Інтеретиціальні прошарки містять значну кількість лімфоцитів.

За результатами гістоензимологічних досліджень активність СДГ в

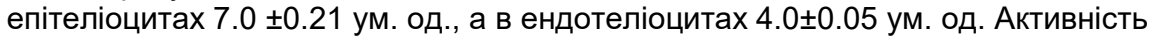
ЛДГ епітеліоцитах $6.5 \pm 0.5$ ум. од., а в ниркових тільцях $5.5 \pm 0.5$ ум. од..

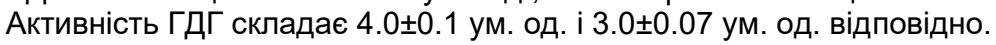

Досліджування нирок на 7-му добу експерименту.

На 7-му добу експерименту розмір, зовнішній вигляд і колір нирок піддослідних щурів ІІ-ої групи практично не змінився в порівнянні з попереднім аналізом 3-ої доби експерименту.

При макроскопічному дослідженні нирки ниркові тільця розміщені групами. У частини з них капілярні клубочки зменшені. Ендотеліоцити набухлі 3 
округлими ядрами, частина з них містить вакуолі. В звивистих канальцях епітелій розміщений в один шар. У частині канальців просвіт не зчитується за рахунок набрякання цитоплазми епітеліоцитів. В деяких канальцях епітелій злущений, він заповнює каналець, його клітини містять пікнотичні ядра. Інтеретиціальні прошарки містять значну кількість лімфоцитів.

Активність СДГ в епітелії канальців $6.5 \pm 0.5$ ум. од., активність СДГ в клубочках ниркових тілець $3.0 \pm 0.4$ ум. од. Активність ЛДГ в епітелії канальців

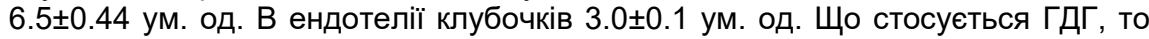
вона складала $5.5 \pm 0.5$ ум. од. та $4.0 \pm 1.0$ ум. од. відповідно.

В цілому розвиток $\mathrm{CCL}_{4}$ - індукованої інтоксикації супроводжується дистрофічними змінами в паренхімі нирок. Збережена активність окисновідновних ферментів, дозволяє думати, що репаративний потенціал не втрачений.

Також, в дослідженні відслідковувались зміни у селезінці щурів з $\mathrm{CCL}_{4}$ інтоксикацією, оскільки цей орган пов'язаний 3 імунною системою відповідальною за захист і регуляцію процесів життєдіяльності. Крім того, наявність зміни в ній може свідчити про системність патологічного процесу.

Селезінка у щурів через 3 дні експерименту візуально не змінена.

Мікроскопічне дослідження виявило збереження секторальної організації. Міжсекторальний прошарок щільний, фіброзний, без сторонніх включень. В кожному 3 4-х секторів розміщується крупний, округлий фолікул. Гермінативний центр збільшений, округлої форми. Лімфоїдні елементи його складові з великими, соковитими ядрами, сторонні включення не виявлені. Периферичний шар тонкий, щільність розподілення елементів в ньому менше, ніж в центрі, зовнішній край периферичного шару нечіткий. Міжфолікулярний простір дифузно зайнятий тісно розташованими лімфоїдними елементами. В цьому просторі зустрічаються скупчення лімфоїдних елементів округлої форми, можливо це знову утворені фолікули. Також, в міжфолікулярному просторі визначаються достатньо великі зерна гемосидерину.

За даними гістоензимологічних досліджень активність СДГ в клітинах фолікул 5.0 0.07 ум. од., активність ЛДГ $3.5 \pm 0.5$ ум. од., ГДГ $4.0 \pm 0.5$ ум. од.

Ha 7-му добу експерименту дослідження стану селезінки не виявили суттєвих змін зовнішнього вигляду по відношенню до її стану на 3-ю добу.

Мікроскопічні дослідження показали, що секторальна організація паренхіми селезінки збережена, але на відміну від минулого строку спостереження міжсекторальний прошарок стоншений, хоча зберігає свою щільність. В центрі кожного сектора розміщена велика кількість фолікулів. Гермінативний центр його візуально більше, ніж у контрольних тварин. Лімфоїдні елементи, 3 збільшеними ядрами, в ньому розміщені дуже щільно. В гермінативному центрі зустрічаються невеликі скупчення з гомогенних еозинофільних мас. Ширина периферичної зони більше, ніж у випадках 3-ої доби експерименту, лімфоїдні елементи в ньому щільно упаковані. В міжфолікулярних просторах розподілені дифузно лімфоїдні елементи, щільність їх розподілення нижче ніж у випадках 3-ої доби експерименту. Окрім того, в міжоролікулярних просторах визначаються мілкі фолікули (новоутворенні) звичайної структури.

За даними гістоензимологічних досліджень активність СДГ в клітинах

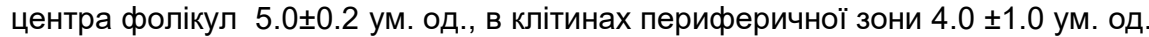

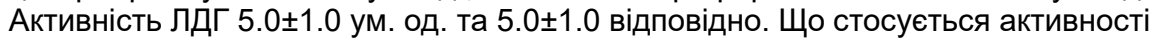
ГДГ, то вона однакова в клітинах обох утворень і складає $4.0 \pm 0.3$ ум. од. 
Таким чином, результати проведених досліджень показали, що $\mathrm{CCL}_{4}$ обумовлена інтоксикація супроводжується дистрофрічними змінами в паренхімі печінки і нирок. Ці зміни з'являються на 3 добу експерименту і зберігаються, i в нирках підсилюються, на 7 добу експерименту. При цьому активність окисновідновних ферментів зберігається, що дозволяє думати про збереженість потенціалу репаративних реакцій. Крім того в селезінці відмічаються ознаки активації деструкції - збільшення розмірів фолікулів і утворення нових. Це очевидно обумовлено потребою в підтримці процесів регуляції і захисту в умовах росту ксенобіотичного навантаження.

\section{Список використаних джерел:}

1. Савченко, В. М., Ніколенко, Є. Я., Сокруто, О.В.& Вовк, К. В. (2009). Гепаторенальний синдром в практиці сімейного лікаря (критерії діагнозу та лікування). Вісник Харківського національного університету імені В. Н. Каразіна, (17), 63-72. Вилучено 3 http://dspace.univer.kharkov.ua/handle/ 123456789/4096

2. Абрагамович, О. О., Абрагамович, М. О. (2011). Гепаторенальний синдром: особливості патогенезу, діагностики, клінічного перебігу та лікування Львівський медичний часоnис, (17), 107-113.

Вилучено

http://aml.lviv.ua/redakce/index.php?xuser=\&lanG=uk\&portal=164\&slozka=1303\&clanek=1592

3. Wadei, H. M., Mai, M. L., Ahsan, N. \& Gonwa, T. A. (2006). Hepatorenal Syndrome: Pathophysiology and Management. Clinical Journal of the American Society of Nephrology, (1), 1066-1079. https://doi.org/10.2215/CJN.01340406

4. Северін, О.С. (2014). Біохімія: підручник. (5-е вид.). Москва: ГЕОТАР-МЕДІА

5. Hui-Ying Zhang, De-Wu Han \& Zhong-Fu Zhao. (2007). Multiple pathogenic factor-induced complications of cirrhosis in rats: A new model of hepatopulmonary syndrome with intestinal endotoxemia. World Journal of Gastroenterology. (25), 3500-3507. https://dx.doi.org/10.3748/wjg.v13.i25.3500

6. Куліцька, М. І., Миронюк, Д. Б., Криницька, І. Я. \& Яремчук, О. 3. (2015) Патогенетичні аспекти гепаторенального синдрому (огляд літератури). Медична та клінічна хімія, (62), 114-120. Вилучено з http://nbuv.gov.ua/UJRN/Medkh_2015_17_1_27

7. Куліцька, М. І. (2015). Функціональний стан печінки у щурів за умов експериментального гепаторенального синдрому. Медична та клінічна хімія. (65). 74-77. https://doi.org/10.11603/mcch.2410-681X.2015.v17.i4.5726

8. Белявський, В.В., Роговий, Ю.Є. (2010). Патогенез гепаторенального синдрому. Буковинський медичний вісник. (55). 119-122. Вилучено 3 https:/l www.bsmu.edu.ua/files/BMV/BMV-2010-14-03(55)/BMV-2010-14-03(55)-119.pdf

9. Angeli, P., Morando, F. (2010) Optimal management of hepatorenal syndrome in patients with cirrhosis. Hepatic Medicine: Evidence and Research. (2), 87-98. https://doi.org/10.2147/HMER.S6918

10. Halit Ziya, Dundar, Tuncay, YIImazlar (2015) Management of hepatorenal syndrome. World Journal of Nephrology, 4(2), 277-286 https://dx.doi.org/10.5527/wjn.v4.i2.277

11. Директива 2010/63 / ЄС Європейського Парламенту та Ради від 22 вересня 2010 року про захист тварин, які використовуються в наукових цілях. Official Journal of the European Union (276), 0033 - 0079. Вилучено 3: http://data.europa.eu/eli/dir/2010/63/oj

12. Про затвердження Порядку проведення науковими установами дослідів, експериментів на тваринах (Наказ Міністерства Освіти і Науки, Молоді та Спорту України). № 249. (2012). Вилучено 3 https://zakon.rada.gov.ua/laws/main/z0416-12 


\section{СУЧАСНІ ПОГЛЯДИ ПРОФІЛАКТИКИ АЛЕРГІЙНИХ ЗАХВОРЮВАНЬ У ДІТЕЙ}

НАУКОВО-ДОСЛІДНА ГРУПА:

Старусева Вікторія Вадимівна

доцент, канд. мед. наук

Харківський національний медичний університет

Гринчук Катерина Олександрівна

студент

Харківський національний медичний університет

Войтенко Таїсія Станіславівна

студент

Харківський національний медичний університет

УKPÄ̈HA

Актуальність Протягом останнього десятиріччя кількість хворих на алергію у світі подвоїлася, в Україні вона виявляється майже в кожної четвертої дитини. Чисельні спостереження свідчать про те, що особливо вразливим до несприятливої дії алергенних чинників довкілля $€$ діти. Це пов'язане з принциповою відмінністю зростаючого організму: суттєво більшою його сприятливістю до будь-якого зовнішнього впливу (хворобливого, чи навпаки, оздоровчого). Проте, не стійкість адаптаційно-компенсаторних реакцій на тлі не сформованості імунної системи дитини, здатні приводити до зриву пристосувального процесу, появу захворювань у молодому віці. Виходячи 3 цих принципових фізіологічних особливостей, алергійні захворювання у дітей характеризуються раннім дебютом, тяжким, 3 характерними рецидивами перебігом, частим переходом до хронічних фоорм, що у кінцевому рахунку призводить до зниження соціальної адаптації, ранньої інвалідності, сприяє погіршенню психічного здоров'я. Тому, проблема алергічних захворювань, на даний час $є$ однією з найактуальніших не тільки серед лікарів алергологів, але й педіатрів.

Мета дослідження $\epsilon$ аналіз існуючих способів та методів профрілактичних процедур алергійних захворювань дітей. Для досягнення даної мети ми використовували методи- аналізу та порівняння існуючих досліджень. А також методи синтезу.

Дослідження будь-якого явища чи процесу слід починати з його ознак, тому, найбільш доцільним $€$ спочатку розглянути прояви алергійних захворювань, якими, найчастіше, $€$ харчова алергія та атопічний дерматит. Найбільш яскраво виражені перши симптоми спостерігаються у дітей грудного віку і основними причинами $\epsilon$ припиненням грудного вигодовування, вплив алкоголю та тютюнопаління, під час вагітності, порушенням дієти годувальницею, складний сімейний анамнез, дефіцит імуноглобуліну класу А, або уведенням прикорму (до розвитку алергії може привести вживання коров'ячого молока, яєць). Найбільшого значення, у цей період, мають саме харчові алергени. Адже надалі може розвинутися до пилкових і побутових алергенів і тоді формуються респіраторні алергійні захворювання, такі як 
алергічний риніт та бронхіальна астма (перші 5-6 років життя). Діти-атопіки мають генетичну схильність до вироблення антитіл імуноглобуліну $\mathrm{E}(\lg \mathrm{E})$ до різних харчових та інгаляторних алергенів. Алергійні захворювання розвиваються у $20 \%$ дітей, які не мають сімейного анамнезу алергії, у $30-50 \%$ дітей, один з батьків якого страждає на алергію та у 60-80\% дітей, обидва батьки яких мають алергію.

На думку вчених, основними заходами профілактики є:

1)дотримання гіпоалергенної дієти вагітних жінок;

2)максимальне подовження терміну грудного вигодовування дитини;

3)обмеження або виключення з раціону дитини молочних продуктів;

4)уникнення пасивного куріння дитини;

5)уникнення вірусних захворювань у дітей раннього віку;

6)створення гіпоалергенних побутових умов.

На противагу цим методам профрілактики, у 1989 році науковець Strachan D. висунув, а згодом доказав гігієнічну гіпотезу (рис.1), згідно з якою причиною збільшення частоти виникнення алергійних захворювань $€$ надмірна гігієна приміщень та зменшення розміру сімей і як наслідок зменшення контакту з бактеріальними антигенами. Вважається, що інфекція стимулює відхилення до нормальної реакції ТН1 і збалансування відношення ТH1 і TH2 відповідей. Отже, мікробне навантаження, велика кількість дітей у родині та не досконала гігієнічна ситуація мають захисний вплив щодо розвитку алергій сиблінг-ефект.

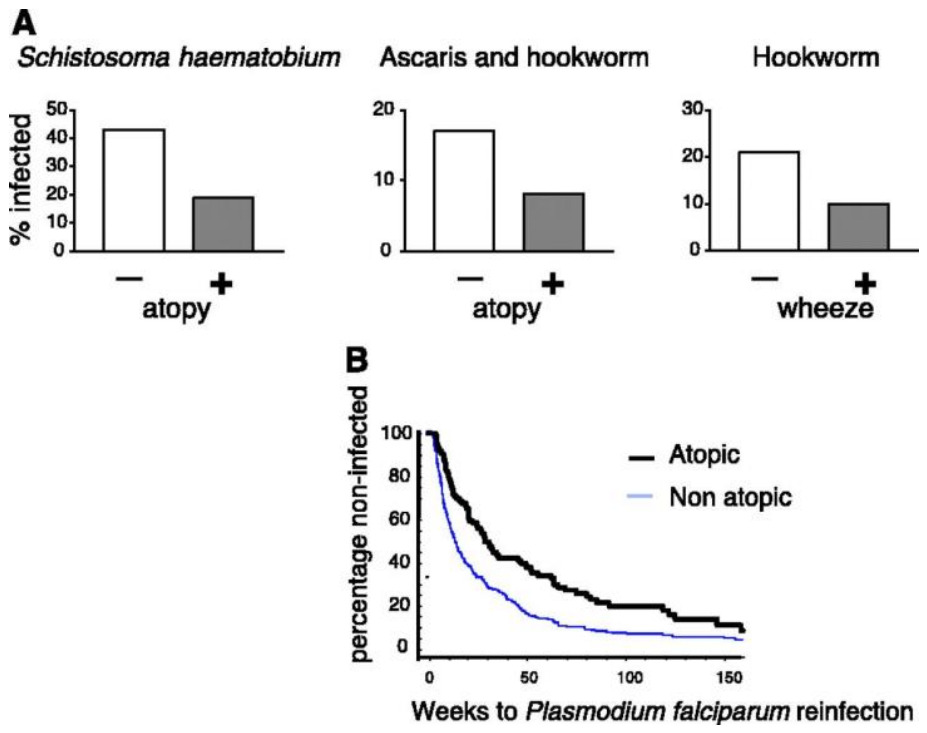

Рис 1. Гігієнічна гіпотеза

На розвиток алергії дітей раннього віку може впливати використання антибіотикотерапії. Застосування антибіотиків у грудному віці може бути пов'язане з підвищеним ризиком подальшого розвитку алергії. Постулюється, що антибіотики, які використовуються для швидкої елімінації мікробних 
агентів, виснажують нормальну бактеріальну флору шлунково-кишкового тракту, яка нормально пригнічує реакції ТН2.

Під час проведення досліджень Г.Г. Уелс, у 1911 році, на морських свинках доказав, що введення антигенів тваринного походження з їжею попереджує розвиток анафрілаксії до цих антигенів ,введених згодом.

У 2015 р. було проведене дослідження в ході якого перша група немовлят отримувала арахісову пасту разом, а інша група немовлят - ні. Результати дослідження показали, що раннє введення в раціон арахісу у подальшому сприяло зменшенню числу алергій на цей харчовий продукт, у порівнянні 3 другою групою немовлят. Тому можемо сказати, що раннє введення алергенних продуктів в раціон дитини запобігає виникненню алергій та стимулює індукцію оральної толерантності.

Висновок. У більшості випадків діагностика алергійних захворювань здійснюється при маніфестації кардинальних симптомів захворювання без урахування доклінічних ознак. На сучасному етапі у зв'язку зі значною поширеністю алергійних захворювань у дітей актуальності набуває реалізація профілактичних програм, розробка нових методів діагностики та лікування алергійної патології. Результати дослідження дозволять своєчасно звернути увагу на стартову симптоматику хвороби, попередити прогресування патологічного процесу.

\section{Список використаних джерел:}

1. Петухова, А.В., Пирожникова, М.М. \& Падруль М.М. (2006). Атопия беременных как фактор риска развития патологического течения беременности. Клинические науки, (2), с.128-129. Пермь, Россия.

2. Макарова, С.Г., Лаврова, Т.Е. \& Вишнёва Е.А. (2015). Первичная профилактика как эфффективный ответ на эпидемию аллергических болезней. Педиатр. ффармакология, (1).

3. Ownby, D.R. (1990). Environmental factors versus genetic determinants of childhood inhalants allergies. J Allergy Clin Immunol, 86-279.

4. Finkelman, F.D., Holmes, J. \& Katona, I.M. (1990). Lymphocyte control of in vivo immunoglobilin isotype selection. Ann Rev Immunol, 8-303. 


\section{ФАКТОРИ, ЩО ВПЛИВАЮТЬ НА ЕФЕКТИВНІСТЬ НАВЧАННЯ СТУДЕНТІВ-МЕДИКІВ}

\section{Валентьєва Аліна Віталіївна}

студентка 3 курсу, 2 медичного факультету Харківський національний медичний університет

Фадєєва Анастасія Володимирівна

студентка 3 курсу, 2 медичного факультету Харківський національний медичний університет

Науковий керівник: Боярський Мирослав Романович канд. мед. наук, викладач кафредри гігієни та екології №1 Харківський національний медичний університет УКРAÏHA

Актуальність. Ефективність навчання це одне з найголовніших питань для студентів будь-якого року навчання та університету. Існує дуже багато фракторів, які впливають на цей процес. Коли ми говоримо саме про підготовку до занять, то перед нами виникає образ американського студента. Він дуже легко одночасно читає книгу, слухає музику, ще й може відповісти на запитання. А ввечері піти гуляти з друзями і не спати всю ніч. Але який результат він утримає від такої підготовки? А він може бути різним.

Мета. Визначити вплив ряду факторів, а саме: вживання напоїв, що містять кофеїн, звуковий супровід, обстановка в кімнаті та тривалість сну на ефективність навчання студентів-медиків третього курсу.

Матеріали і методи. У ході роботи було проведено анкетування серед студентів. Їм було запропоновано відповісти на декілька запитань стосовно концентрації уваги під час навчання, впливу вживання напоїв ,що містять кофеїн, зміни концентрації уваги при звуковому супроводі, необхідності перерви та тривалості сну на ефективність навчання.

Результати. Під час дослідження було з'ясовано, що з 50 студентівмедиків 38\% періодично відволікаються під час підготовки до занять та $24 \%$ дуже часто, 34\% вживають напої, що містять кофеїн 2-3 рази на тиждень, а $32 \%$ навіть щодня, при цьому $18 \%$ помічають погіршення пам'яті після цього, $66 \%$ студентів намагаються займатися при повній тиші саме тому, що при одночасному навчанні та переглядом фрільму або прослуховуванням музики у $70 \%$ студентів знижується увага. Вдома $62 \%$ студентів роблять періодичні паузи. $34 \%$ відчувають найбільшу розумову активність зранку, а $20 \%$ вночі. $32 \%$ студентів намагається дотримуватися розпорядку сну, а $32 \%$ ні. При цьому тривалість сну повинна становити 7-8 годин, що спостерігається лише у $42 \%$. Зменшення сну негативно впливає на процес навчання у $80 \%$ студентів.

Висновки. У ході роботи було з'ясовано, що досягненню максимальної ефрективності в навчанні студентів-медиків третього курсу в найбільшій мірі сприяє спокійна тиха обстановка, періодичні паузи та дотримання розпорядку сну. 


\section{ヘ’OГO}

COLLECTION DE PAPIERS SCIENTIFIQUES

\section{SUR LES MATÉRIAUX DE LA CONFÉRENCE SCIENTIFIQUE ET PRATIQUE INTERNATIONALE «PROBLÈMES ET PERSPECTIVES D'INTRODUCTION DE LA RECHERCHE SCIENTIFIQUE INNOVANTE» 20 novembre 2019 • Bruxelles, Belgique}

\section{VOLUME 3}

Ukrainien, russe, français et anglais

Les matériaux sont imprimés dans le texte de l'auteur Le comité organisateur ne partage pas toujours la position des auteurs Pour l'exactitude de ce matériel, les auteurs portent la responsabilité

Signé pour impression le 29.11.2019. Format $60 \times 84 / 16$.

Papier offset. Arial type. Impression numérique

Feuilles imprimées conditionnées 8,25.

Un tirage de 100 exemplaires.

Imprimé à partir de la mise en page originale finie.

Coordonnées du comité d'organisation:

21037, Ukraine, Vinnytsia, st. Zodchih, 18, bureau 81

Plateforme scientifique européenne

Téléphones: +38098 1948380; +38098 1956755

E-mail: info@ukrlogos.in.ua

www.ukrlogos.in.ua | www.ojs.ukrlogos.in.ua 